University of Tennessee Health Science Center

UTHSC Digital Commons

\title{
Design, Synthesis, and Evaluation of Small Molecules in the Discovery of Novel Antimicrobial Agents
}

Kimberly D. Grimes

University of Tennessee Health Science Center

Follow this and additional works at: https://dc.uthsc.edu/dissertations

Part of the Other Medical Sciences Commons, and the Pharmaceutics and Drug Design Commons

\section{Recommended Citation}

Grimes, Kimberly D. , "Design, Synthesis, and Evaluation of Small Molecules in the Discovery of Novel Antimicrobial Agents" (2008). Theses and Dissertations (ETD). Paper 114. http://dx.doi.org/10.21007/ etd.cghs.2008.0119.

This Dissertation is brought to you for free and open access by the College of Graduate Health Sciences at UTHSC Digital Commons. It has been accepted for inclusion in Theses and Dissertations (ETD) by an authorized administrator of UTHSC Digital Commons. For more information, please contact jwelch30@uthsc.edu. 


\title{
Design, Synthesis, and Evaluation of Small Molecules in the Discovery of Novel Antimicrobial Agents
}

\author{
Abstract \\ The increasing prevalence of antibiotic-resistant bacteria, including Mycobacterium tuberculosis, \\ Streptococcus pneumoniae, Staphylococcus aureus, and Enterococcus faecalis, pushes us to discover \\ new antibacterial agents to maintain adequate patient coverage. This body of work highlights the use of \\ medicinal chemistry methodologies that encompass cross-disciplinary fields of study. Chapter 1 gives an \\ introduction to the antibacterial drug targets, resistance, and how scientists are working to overcome \\ obstacles encountered with drug-resistant bacteria. It also details modern medicinal chemistry \\ applications in antimicrobial drug discovery. Chapter 2 details the use of a structure-guided library \\ approach to drug design, in which large virtual libraries against the target are generated and filtered, \\ based on pharmacophoric and structural constraints, to produce smaller and more structurally complex \\ libraries prioritized for synthesis. In this work, bi-aryl sulfonamide libraries using contemporary medicinal \\ chemistry techniques were synthesized as potential inhibitors of Mycobacterium tuberculosis cell wall \\ biosynthesis via the rhamnose pathway. Chapter 3 describes the discovery of novel inhibitors of the PIsX/ \\ PIsY pathway to phosphatidic acid, a key intermediate in the biosynthesis of phospholipids in Gram- \\ positive bacteria. Substrate mimics, incorporating various bioisosteric replacement head groups, were \\ discovered demonstrating good enzyme inhibition and good antimicrobial activity against clinically \\ relevant bacteria. Finally, Chapter 4 provides an overall discussion of the work detailed in this dissertation \\ and future directions that will continue the advancement of these projects.

\section{Document Type \\ Dissertation} \\ Degree Name \\ Doctor of Philosophy (PhD)

\section{Program} \\ Medicinal Chemistry \\ Research Advisor \\ Richard E. Lee, Ph.D.

\section{Keywords} \\ Combinatorial chemistry; parallel synthesis; tuberculosis; Gram-positive bacteria; sulfonamides; \\ acylphosphates

\section{Subject Categories} \\ Medical Sciences | Medicine and Health Sciences | Other Medical Sciences | Pharmaceutics and Drug \\ Design | Pharmacy and Pharmaceutical Sciences
}


DESIGN, SYNTHESIS, AND EVALUATION OF SMALL MOLECULES IN THE DISCOVERY OF NOVEL ANTMICROBIAL AGENTS

\author{
A Dissertation \\ Presented for \\ The Graduate Studies Council \\ The University of Tennessee \\ Health Science Center
}

\author{
In Partial Fulfillment \\ Of the Requirements for the Degree \\ Doctor of Philosophy \\ From The University of Tennessee
}

By

Kimberly D. Grimes

May 2008 
Copyright (C) 2008 by Kimberly D. Grimes

All rights reserved 


\section{DEDICATION}

I would like to dedicate this body of work to my greatest supporter and idol, my mother Mrs. Debora A. Stewart. 


\section{ACKNOWLEDGEMENTS}

I would first like to acknowledge my mentor and advisor, Dr. Richard E. Lee for giving me a chance to advance professionally. He eagerly welcomed me into the Medicinal Chemistry program and into his lab without hesitation. In the last $51 / 2$ years, I've matured into a better scientist. I have also become a better person because of his guidance and mentorship. I would also like to give special thanks to my committee members, Dr. John K. Buoalmwini, Dr. Isaac O. Donkor, Dr. Duane D. Miller, and Dr. Jie Zheng for your support and guidance throughout my graduate tenure. I give special thanks to the past and present members of the "Lee lab": Dr. Kerim Babaoglu, Dr. Kristopher Virga, Dr. Rajendra Tangallapally, Dr. Jianjun Qi, Dr. Raghunandan Yendapally, Dr. Kirk Hevener, Dr. Dianqing Sun, Dr. Julian Hurdle, Dr. Sucheta Kudrimoti, Dr. Rakesh, Robin Lee, Elizabeth Carson, Engy Maharous, Joshua Brown, Jerrod Scarborough, Jason Wilson, AnTawan Daniels, Neena Joshi, and David Ball for their support, assistance, and friendship. Special thanks go to Dr. Qi, Dr. Kudrimoti, Dr. Baboglu, Dr. Virga, Dr. Tangalapally, Dr. Yendapally, and Dr. Hurdle for their assistance, advice, and expertise. I would also like to extend thanks to our collaborators on the research projects in this dissertation: Dr. Michael NcNeil (Colorado State University), Dr. James Naismith (St. Andrew's University), Dr. Charles Rock (St. Jude Children's Research Hospital), Dr. Vicki Luna (University of South Florida) and their lab members. I would like to thank the general body of the Black Graduate Student Association, as they have been pivotal to my overall growth as an individual and providing me with a great support system. I'd also like to give special thanks to my friends at the University of Tennessee, especially Ms. Ja'Wanda Grant. Without Ja'Wanda, I'm not sure I would have made it this far. I thank her dearly for being my sounding board and encouraging me to make it through to the end. Last, but certainly not least, I'd like to thank my family who has supported me and kept me encouraged so that I could complete the task at hand. 


\begin{abstract}
The increasing prevalence of antibiotic-resistant bacteria, including Mycobacterium tuberculosis, Streptococcus pneumoniae, Staphylococcus aureus, and Enterococcus faecalis, pushes us to discover new antibacterial agents to maintain adequate patient coverage. This body of work highlights the use of medicinal chemistry methodologies that encompass cross-disciplinary fields of study. Chapter 1 gives an introduction to the antibacterial drug targets, resistance, and how scientists are working to overcome obstacles encountered with drug-resistant bacteria. It also details modern medicinal chemistry applications in antimicrobial drug discovery. Chapter 2 details the use of a structure-guided library approach to drug design, in which large virtual libraries against the target are generated and filtered, based on pharmacophoric and structural constraints, to produce smaller and more structurally complex libraries prioritized for synthesis. In this work, bi-aryl sulfonamide libraries using contemporary medicinal chemistry techniques were synthesized as potential inhibitors of Mycobacterium tuberculosis cell wall biosynthesis via the rhamnose pathway. Chapter 3 describes the discovery of novel inhibitors of the PlsX/PlsY pathway to phosphatidic acid, a key intermediate in the biosynthesis of phospholipids in Gram-positive bacteria. Substrate mimics, incorporating various bioisosteric replacement head groups, were discovered demonstrating good enzyme inhibition and good antimicrobial activity against clinically relevant bacteria. Finally, Chapter 4 provides an overall discussion of the work detailed in this dissertation and future directions that will continue the advancement of these projects.
\end{abstract}




\section{TABLE OF CONTENTS}

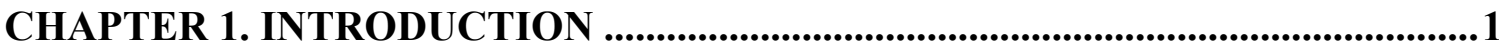

Introduction to Antibiotics and Antimicrobial Agents.............................................. 1

Inhibitors of Folic Acid Metabolism .................................................................. 1

Inhibitors of Cell Wall Biosynthesis ..................................................................

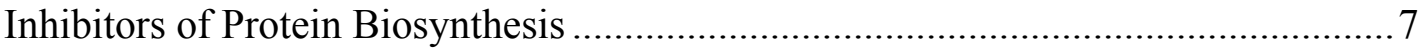

Inhibitors of Nucleic Acid Biosynthesis .............................................................

Inhibitors of DNA-Directed RNA Polymerase …………........................................11

Resistance to Antibiotic Chemotherapy …………….............................................. 11

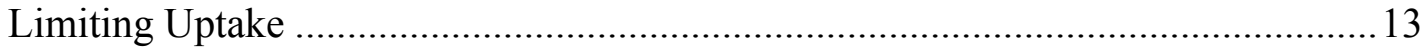

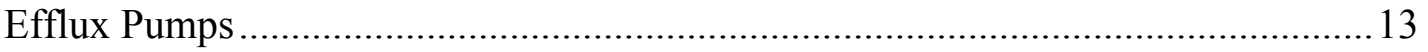

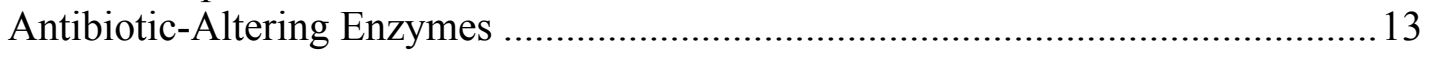

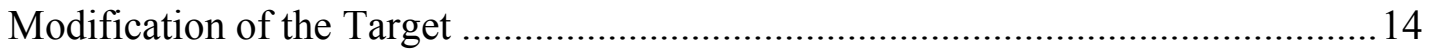

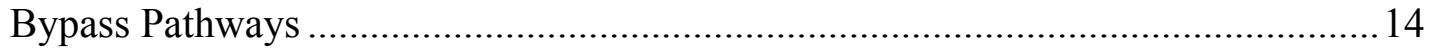

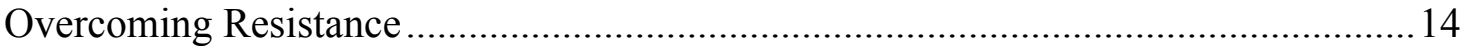

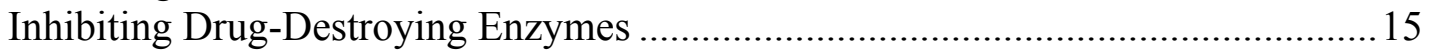

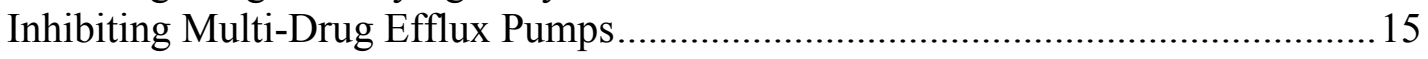

Introducing New Chemical Entities (NCE) ............................................................ 17

Pursuing Novel Targets with Novel Modes of Action ..............................................20

Medicinal Chemistry Applications in Antimicrobial Drug Discovery …………..........24

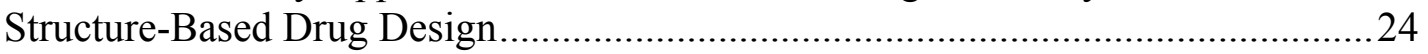

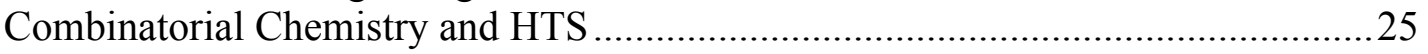

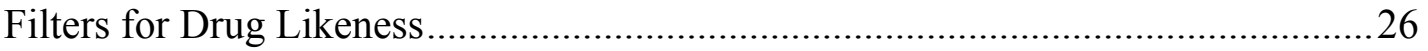

Research Objectives ..........................................................................................2

Sulfonamide Libraries as Inhibitors of Mycobacterium tuberculosis Cell Wall

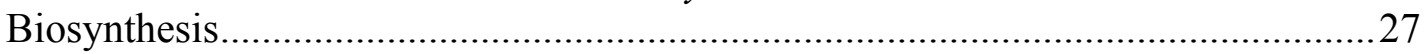

Discovery of Novel Inhibitors in Phospholipid Biosynthesis ...................................28

\section{CHAPTER 2: STRUCTURE-GUIDED SULFONAMIDE LIBRARIES AS INHIBITORS OF MYCOBACTERIUM TUBERCULOSIS CELL WALL

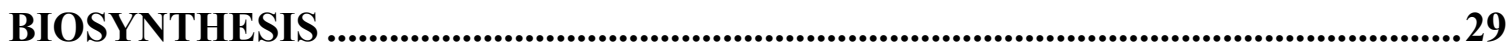

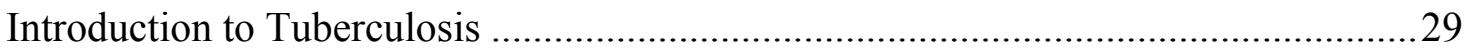

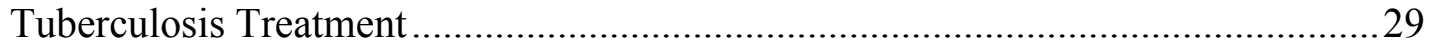

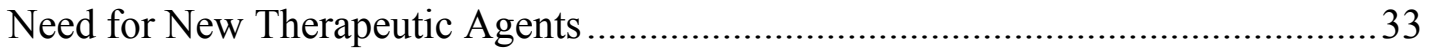

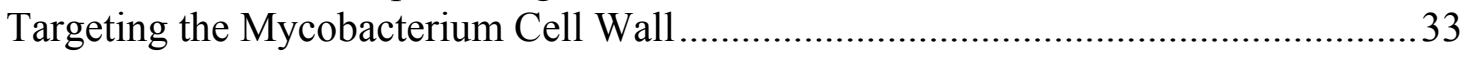

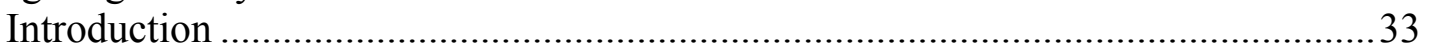

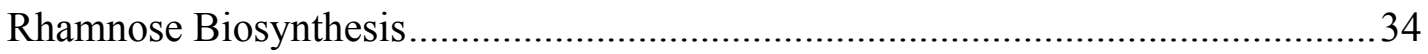

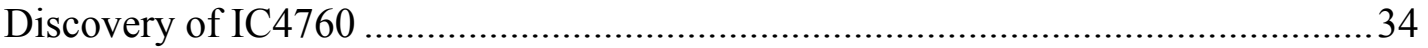

Generating a Pharmacophore Model ..................................................................... 37

Virtual Screening Techniques in the Discovery of Novel RmlC Inhibitors...............37

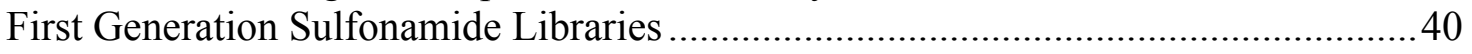

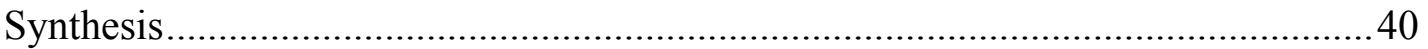

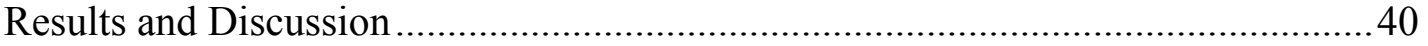

Second Generation Bi-Aryl Sulfonamide Library ....................................................43 


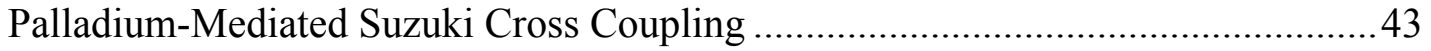

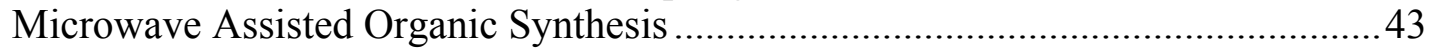

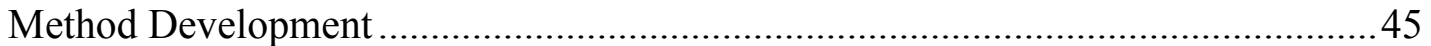

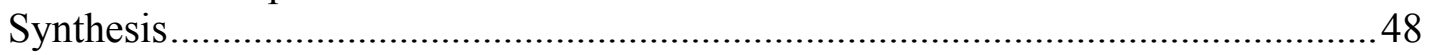

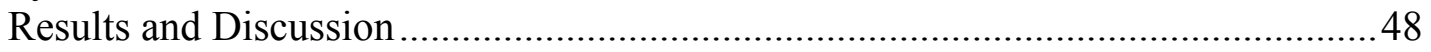

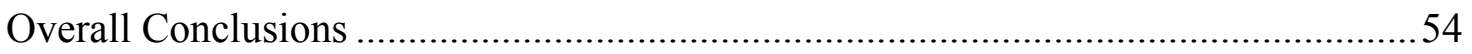

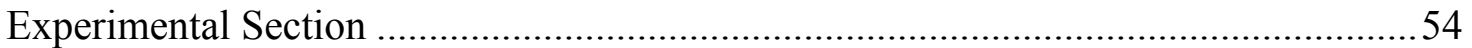

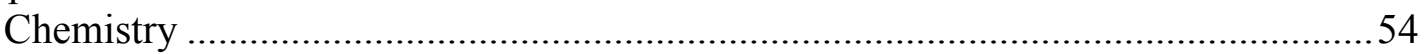

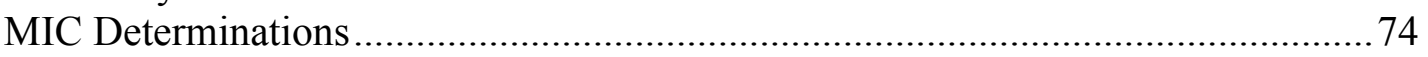

\section{CHAPTER 3: NOVEL INHIBITORS OF PHOSPHOLIPID}

BIOSYNTHESIS IN GRAM-POSITIVE BACTERIA....................................................76

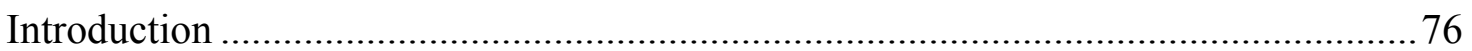

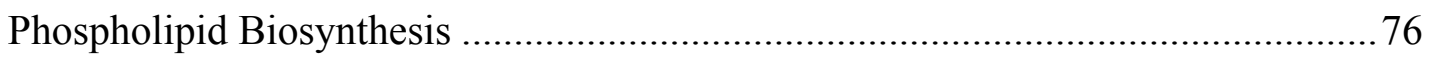

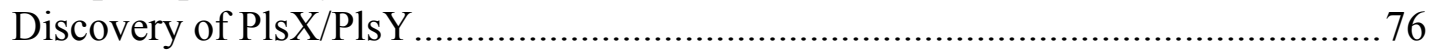

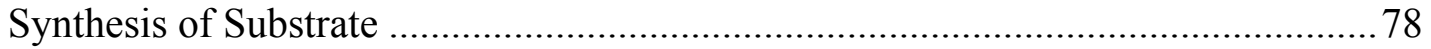

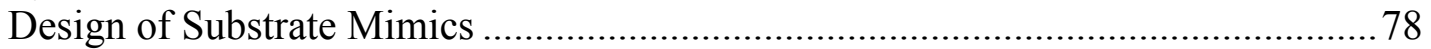

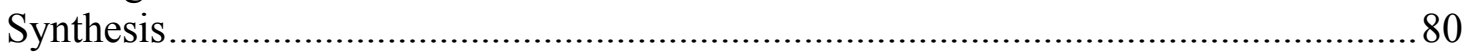

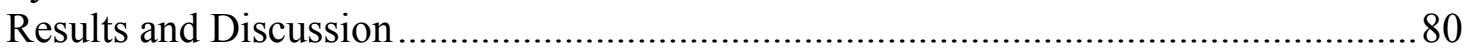

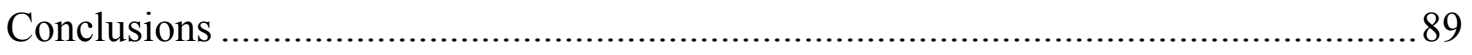

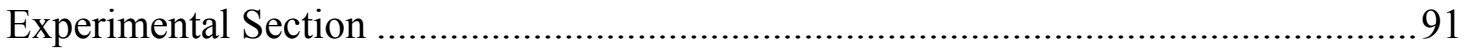

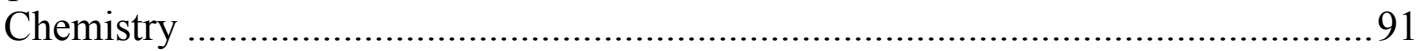

Preparation and Assay of Acyltransferase Activity .............................................. 103

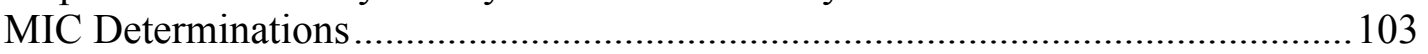

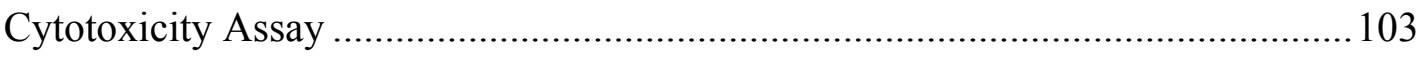

CHAPTER 4: OVERALL DISCUSSION OF RESEARCH PROJECTS ...............104

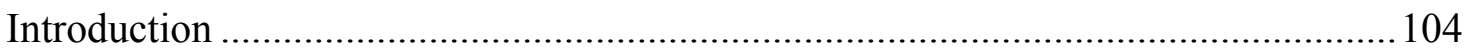

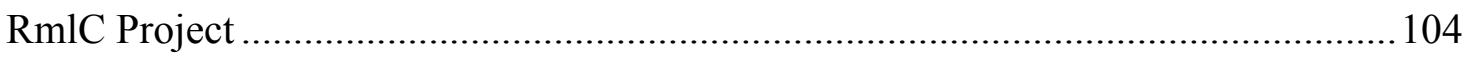

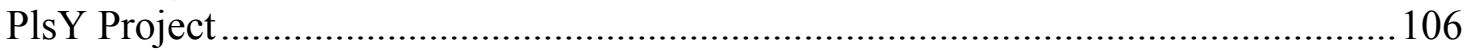

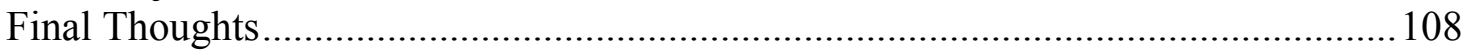

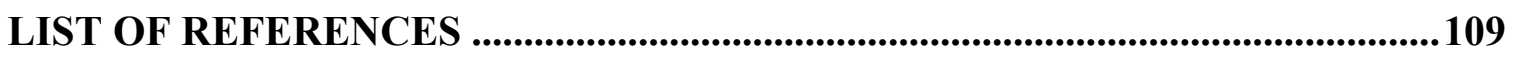

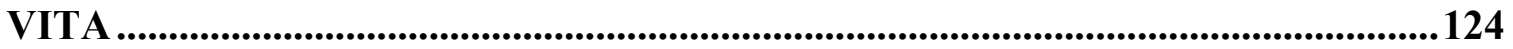




\section{LIST OF TABLES}

Table 2.1: Activity of First Generation Sulfonamide Library .......................................42

Table 2.2: Reaction Conditions for Chemistry Optimization....................................... 46

Table 2.3: \% Purity of Compounds for Method Development .....................................47

Table 2.4: Activity of Second Generation Bi-Aryl Sulfonamide Library ......................51

Table 3.1: Enzyme Activity of Acylphosphate Mimics ................................................83

Table 3.2: Antimicrobial Activity of Acylphosphate Mimetics against a Panel of Gram-Positive Bacteria. ......................................................................... 86

Table 3.3: Antimicrobial Activity of Acylphosphate Mimics against a Panel of Bacillus cereus Strains .87

Table 3.4: Antimicrobial Activity against a Panel of Bacillus anthracis Strains...........88

Table 3.5: Comparison of Inhibitory Activity for SpPlsY and BaPlsY1 ......................90 


\section{LIST OF FIGURES}

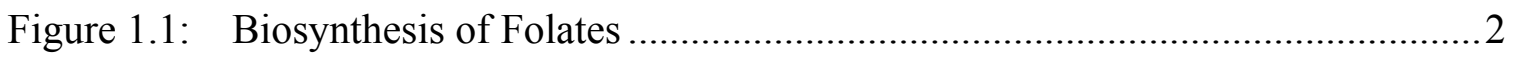

Figure 1.2: Prontosil and Its Active Metabolite, Sulfanilamide ........................................ 4

Figure 1.3: Structures of Inhibitors of the Folate Biosynthesis........................................ 4

Figure 1.4: General Skeleton of the Four Classes of $\beta$-Lactam Antibiotics...................... 4

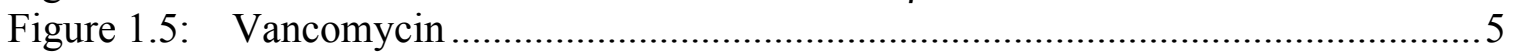

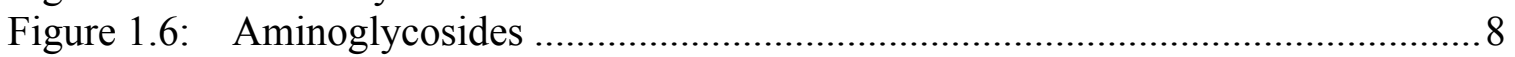

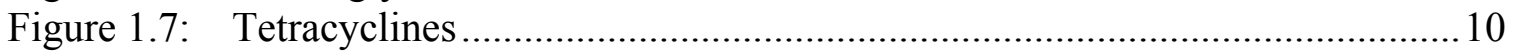

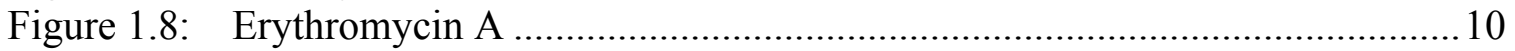

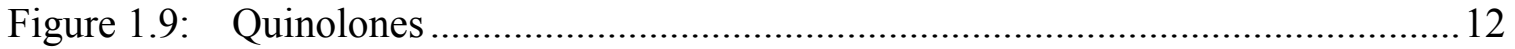

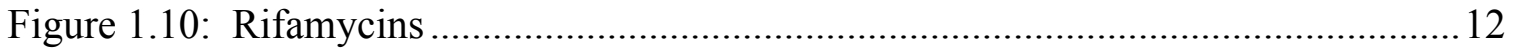

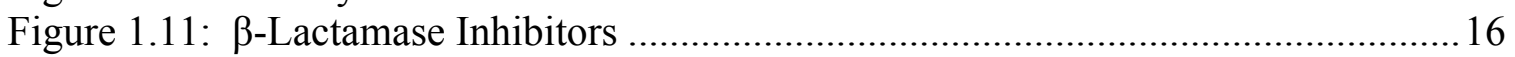

Figure 1.12: Inhibitor of Aminoglycoside-2"-O-Adenyltransferase .................................. 16

Figure 1.13: Reserpine, an Inhibitor of Multi-Drug Efflux Pumps ...................................16

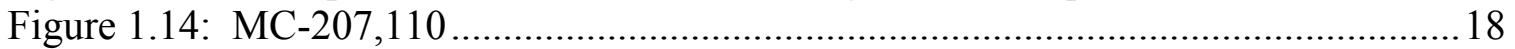

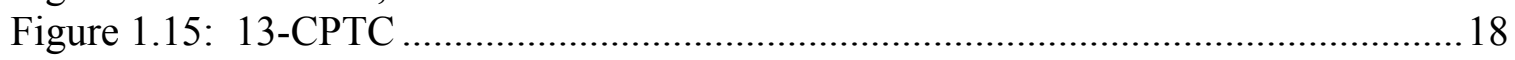

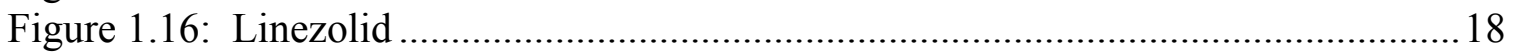

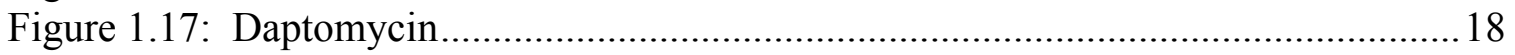

Figure 1.18: Telithromycin................................................................................ 19

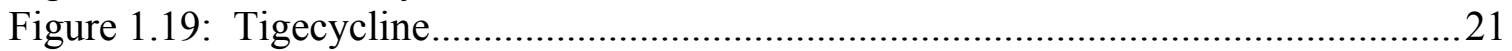

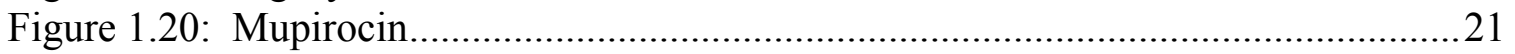

Figure 1.21: Fatty Acid Biosynthesis .......................................................................23

Figure 1.22: Clinical Candidates that Inhibit Bacterial Fatty Acid Synthesis..................23

Figure 2.1: First-Line Tuberculosis Treatment .............................................................30

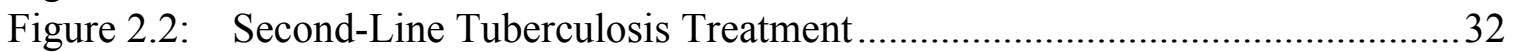

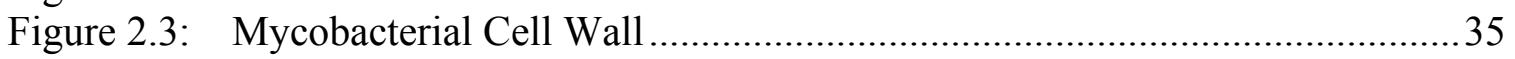

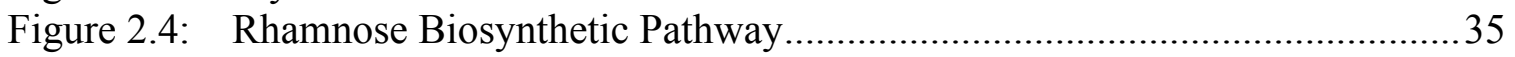

Figure 2.5: Original Pyrazalone Inhibitor 9861 from Screen..........................................36

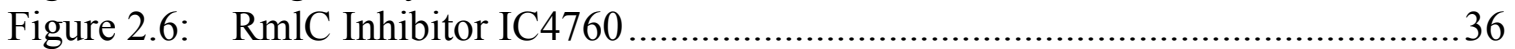

Figure 2.7: Crystal Structure of dTDP-Rhamnose in RmlC Active Site..........................38

Figure 2.8: Crystal Structure of Inhibitor IC4760 in RmlC Active Site .........................38

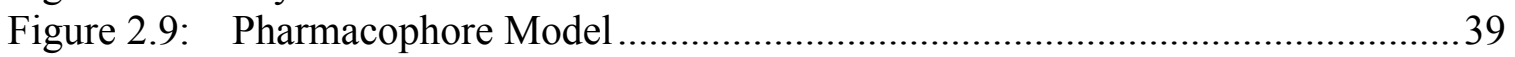

Figure 2.10: Thiazolidinone Scaffold for Inhibitors of RmlC..........................................39

Figure 2.11: Target Sulfonamide Libarary ................................................................4

Figure 2.12: Retrosynthetic Analysis for Second Generation Sulfonamide Library .......44

Figure 2.13: Docking Solution of 2.8jg...................................................................53

Figure 3.1: Phosphatidic Acid Formation ................................................................... 77

Figure 3.2: Distribution of $p l s$ Genes in Bacteria........................................................ 77

Figure 3.3: Design of Substrate Mimics of Acylphosphate. .......................................... 81

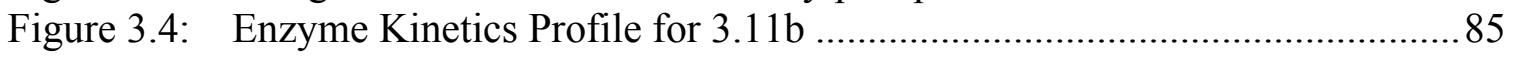

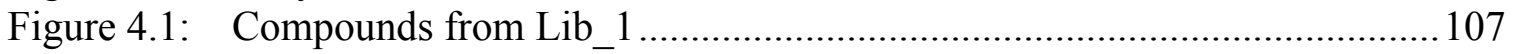

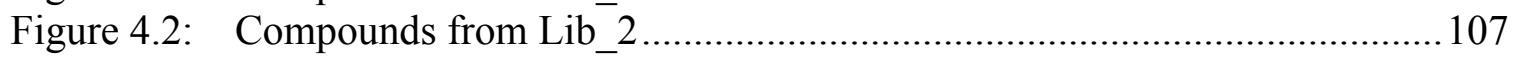

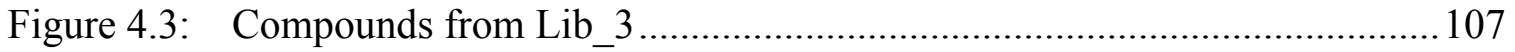




\section{LIST OF SCHEMES}

Scheme 2.1: First Generation Sulfonamide Library..................................................... 41

Scheme 2.2: Compounds for Chemistry Optimization ................................................46

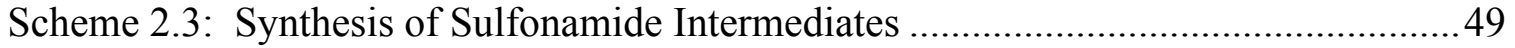

Scheme 2.4: Synthesis of Bi-Aryl Sulfonamides via Suzuki Coupling ..........................50

Scheme 3.1: Synthesis of Monopalmitoyl Phosphate ...................................................79

Scheme 3.2: Synthesis of Ketophosphonates and Acyl $\alpha, \alpha$-Difluromethyl

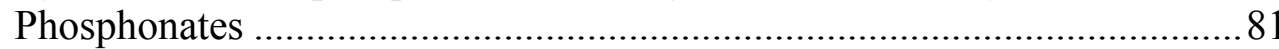

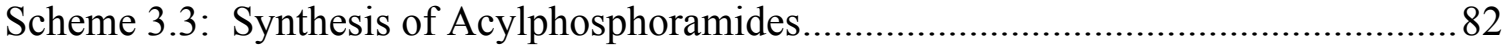

Scheme 3.4: Synthesis of Reverse Amide Phosphonates ............................................ 82

Scheme 3.5: Synthesis of Acylsulfamates and Acylsulfamides ................................... 82 


\section{LIST OF ABBREVIATIONS}

$\begin{array}{ll}\text { aaRS } & \text { Amino-Acyl tRNA Synthetase } \\ \text { ACP } & \text { Acyl Carrier Protein } \\ \text { acyl-PO } & \text { Acyl Phosphate } \\ \text { ADMET } & \text { Absorption, Distribution, Metabolism, Excretion, Toxicity } \\ \text { AIDS } & \text { Autoimmunodeficiency Syndrome } \\ \text { ATCC } & \text { American Type Culture Collection } \\ \text { ATP } & \text { Adenosine Triphosphate } \\ \text { BA } & \text { Bacillus anthracis } \\ \text { BCG } & \text { Bacille Calmette-Guerin } \\ \text { BS } & \text { Bacillus subtilis } \\ \text { CFU } & \text { Colony Forming Units } \\ \text { CoMFA } & \text { Comparative Molecular Field Analysis } \\ \text { CoMSIA } & \text { Comparative Molecular Similarity Indices Analysis } \\ \text { CYP } & \text { Cytocrome P-450 } \\ \text { DCM } & \text { Dichloromethane } \\ \text { DDRP } & \text { DNA Dependent RNA Polymerase } \\ \text { DHFR } & \text { Dihydrofolate Reductase } \\ \text { DHPS } & \text { Dihydropteroate Synthase } \\ \text { DIPEA } & \text { N,N-Diisopropylethylamine } \\ \text { DMAP } & \text { Dimethylamino Pyridine } \\ \text { DME } & \text { Dimethoxyethane } \\ \text { DMF } & \text { Dimethylformamide } \\ \text { DNA } & \text { Deoxyribonucleic Acid } \\ \text { dTDP } & \text { Deoxythymidine Diphosphate } \\ \text { dTTP } & \text { Deoxythymidine Triphosphate } \\ \text { EDCI } & \text { N-(3-Dimethylaminopropyl)-N'-Ethylcarbodiimide } \\ \text { EF } & \text { Enterococcus faecalis } \\ \text { EMB } & \text { Ethambutol } \\ \text { ESI-MS } & \text { Electrospray Ionisation Mass Spectrometry } \\ \text { EtOH } & \text { Ethanol } \\ \text { FDA } & \text { Food, Drug, and Cosmetic Act } \\ \text { G3P } & \text { Glycerol-3-Phosphate } \\ \text { HIV } & \text { Human Immunodeficiency Virus } \\ \text { HOBt } & \text { 1-Hydroxybenzotriazole } \\ \text { HPLC } & \text { High Performance Liquid Chromatography } \\ \text { HTS } & \text { High Throughput Screening } \\ \text { INH } & \text { Isoniazid } \\ \text { katG } & \text { Catalase-Peroxidase Enzyme } \\ & \end{array}$




$\begin{array}{ll}\text { LCMS } & \text { Liquid Chromatography Mass Spectrum } \\ \text { MDRTB } & \text { Multidrug Resistant Tuberculosis } \\ \text { MeOH } & \text { Methanol } \\ \text { MIC } & \text { Minimum Inhibitory Concentrations } \\ \text { MLSB } & \text { Macrolide-Lincosamide-Streptogramin B } \\ \text { MRSA } & \text { Methicillin Resistant Staphylococcus aureus } \\ \text { MSSA } & \text { Methicillin Susceptible Staphylococcus aureus } \\ \text { MW } & \text { Molecular Weight } \\ \text { NAD } & \text { Nicotinamide Adenine Dinucleotide } \\ \text { NCE } & \text { New Chemical Entity } \\ \text { NMR } & \text { Nuclear Magnetic Resonance } \\ \text { OD } & \text { Optical Density } \\ \text { PABA } & \text { Para Amino Benzoic Acid } \\ \text { PAS } & \text { Para Amino Salicylic Acid } \\ \text { PBPs } & \text { Penicillin Binding Proteins } \\ \text { PD } & \text { Pharmacodynamics } \\ \text { Phe } & \text { Phenylalanine } \\ \text { PK } & \text { Pharmacokinetics } \\ \text { PS-DMAP } & \text { Polymer-Supported Dimethylamino Pyridine } \\ \text { PS Pd(Ph })_{4} & \text { Polymer-Supported Tetrakis(triphenylphosphine)Palladium(0) } \\ \text { PZA } & \text { Pyrazinamide } \\ \text { QSAR } & \text { Quantitative Structure Activity Relationship } \\ \text { RIF } & \text { Rifampin } \\ \text { RmlA } & \text { Glucose-1-Phosphate Thymidyltransferase } \\ \text { RmlB } & \text { dTDP-D-Glucose 4,6-Dehydratase } \\ \text { RmlC } & \text { dTDP-6-Deoxy-D-Xylo-4-Hexulose 3,5-Epimerase } \\ \text { RmlD } & \text { dTDP-6-Deoxy-L-Xylo-4-Hexulose Reductase } \\ \text { RNA } & \text { Ribonucleic Acid } \\ \text { RND } & \text { Resistance Nodulation Cell Division } \\ \text { RP-HPLC } & \text { Reverse Phase High Performance Liquid Chromatography } \\ \text { rRNA } & \text { Ribosomal RNA } \\ \text { SAR } & \text { Structure Activity Relationship } \\ \text { SBDD } & \text { Structure Based Drug Design } \\ \text { SP } & \text { Streptococcus pneumonia } \\ \text { TB } & \text { Tuberculosis } \\ \text { TFA } & \text { Trifluoroacetic Acid } \\ \text { THF } & \text { Tetrahydrofuran } \\ \text { TLC } & \text { Thin Layer Chromatography } \\ \text { TMSBr } & \text { Bromotetramethylsilane } \\ \text { tRNA } & \text { Transfer Ribonucleic Acid } \\ \text { Tyr } & \text { Tyrosine } \\ & \end{array}$




$\begin{array}{ll}\text { UTIs } & \text { Urinary Tract Infections } \\ \text { UV } & \text { Ultraviolet } \\ \text { VISA } & \text { Vancomycin Intermediate } S \text {. aureus } \\ \text { VRE } & \text { Vancomycin Resistant Enterococci } \\ \text { VS } & \text { Virtual Screening } \\ \text { WDI } & \text { World Drug Index } \\ \text { WHO } & \text { World Health Organization } \\ \text { XDRTB } & \text { Extensively Drug Resistant Tuberculosis } \\ \text { 3-D } & \text { Three-Dimensional } \\ \text { 6-APA } & \text { 6-Amino-Penicillanic Acid } \\ \text { 7-ACA } & \text { 7-Aminocephalosporanic Acid }\end{array}$




\section{CHAPTER 1. INTRODUCTION}

\section{Introduction to Antibiotics and Antimicrobial Agents}

Antibiotics are among the most frequently prescribed drugs on the market today. ${ }^{1}$ They are informally described as substances produced by or derived from certain fungi, bacteria, and other organisms, that can destroy or inhibit the growth of other microorganisms. However, the name antibiotics have expanded to include antimicrobial agents which are synthetic drugs that are unrelated to natural products but still inhibit or kill microorganisms. ${ }^{1}$ Historically, we've made use of our own powerful immune system and public health measures, such as good sanitation, to ward off harmful bacteria. However, at times these measures are insufficient creating the need for other forms of intervention, through the use of therapeutic agents. ${ }^{1}$ Antibiotics are generally used to treat bacterial infections that can affect the growth of bacteria in two ways: by killing the bacteria (bactericidal) or inhibiting or impeding the growth of the bacteria (bacteriostatic) allowing the immune system to then clear the infection. Antibiotic agents have only been around since the early 1900's. The first drug, prontosil, a prodrug of the sulfa drug sulfanilamide, was introduced in 1936. This was soon followed by penicillin in 1942. Since then, more than 100 different antibiotics have been introduced to the market. Modifications to the known drug classes are often tripartite in scope to either improve their potency, pharmacokinetic/pharmacodynamic (PK/PD) properties and/or to overcome resistance mechanisms. On the basis of their mechanism of action, antibiotics are generally classified as (1) those that block specific steps in folic acid metabolism; (2) those that affect bacterial cell-wall biosynthesis; (3) those that interfere with protein biosynthesis; and (4) those that affect nucleic acid biosynthesis and transcription.

\section{Inhibitors of Folic Acid Metabolism}

Folic acid is a key cofactor required for the biosynthesis of many cellular components in all living organisms. ${ }^{2}$ It is required in DNA synthesis by serving as an intermediate in the transfer of methyl, formyl, and other single-carbon fragments in the biosynthesis of purine nucleotides. ${ }^{3}$ Microorganisms must synthesize folates de novo through the folate biosynthetic pathway summarized in Figure 1.1. In contrast, mammals obtain folates as apart of their daily diet making this pathway attractive for antimicrobial drug design. ${ }^{2}$ Inhibition of folate biosynthesis results in the inability of the bacteria to multiply since further nucleic acid biosynthesis is impossible due to the folate

requirement. ${ }^{1}$ Accordingly, drug discovery strategies against the folic acid pathway have targeted two enzymes: dihydropteroate synthase (DHPS) and dihydrofolate reductase (DHFR).

\section{Sulfonamides}

Sulfonamides were discovered in the mid 1930's by a German scientist, Gerhard Domagk of Bayer Laboratories. As a result, Domagk was awarded the Nobel Prize in 


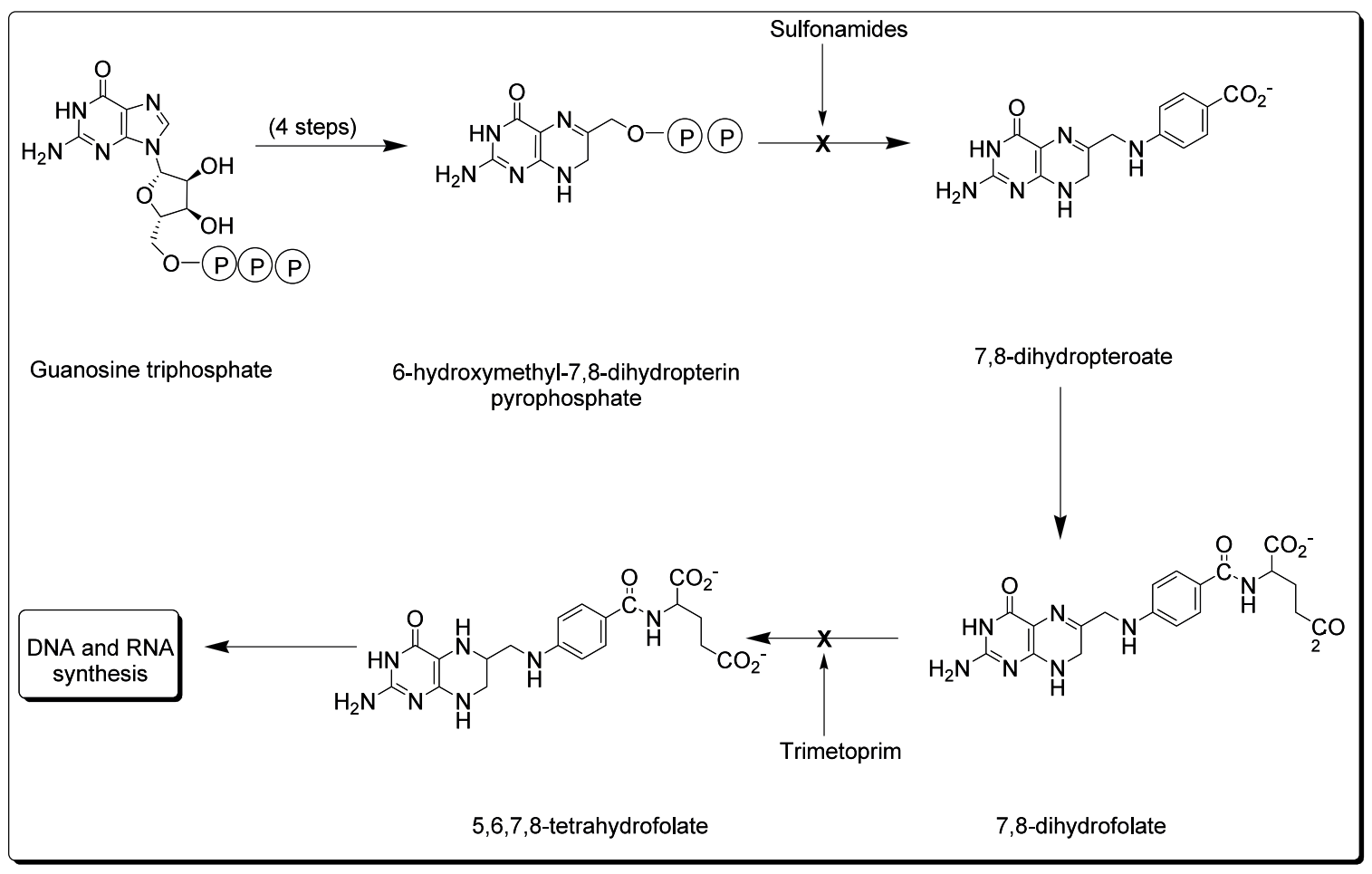

Figure 1.1: Biosynthesis of Folates 
1939 on the antibacterial nature of dyes on streptococci. ${ }^{4}$ Prontosil, the first drug of the class, was interestingly found to be active in vivo, but not in vitro. ${ }^{4}$ It was later discovered that prontosil was actually a prodrug with the active component being the metabolized product, $p$-aminobenzenesulfonamide (sulfanilamide) ${ }^{5}$ (Figure 1.2). The discovery of sulfanilamide's antibacterial properties ushered in the modern anti-infective era. ${ }^{1}$

The sulfonamides are bacteriostatic agents that act by inhibiting DHPS. ${ }^{6,7}$ DHPS catalyses the conversion of $p$-aminobenzoic acid (PABA) to dihydropteroate, a key step in folate synthesis. ${ }^{8}$ Sulfonamides are competitive inhibitors and in some bacteria can also act as substrates replacing PABA, resulting in a dead-end product. ${ }^{9}$ Currently, sulfamethoxazole (Figure 1.3) is the most commonly used drug in the class. It is mainly used in combination with the dihydrofolate reductase inhibitor, trimethoprim, to treat urinary tract infections (UTI's). This is an excellent example of synergistic drug combination that increases efficacy, broadens antibacterial spectrum and lowers the prospect for development of resistant strains.

\section{Trimethoprim}

The final step in the pathway to folic acid is performed by DHFR, which converts dihydrofolate to tetrahydrofolate. ${ }^{10}$ This part of the pathway is found in both bacteria and mammals, therefore selective inhibition of bacterial DHFR is crucial. Trimethoprim, a member of the diaminopyrimidine class, inhibits bacterial DHFR at much lower concentrations than its mammalian counterpart providing the basis for selective toxicity. ${ }^{1}$ Alone, it is a well tolerated broad-spectrum agent active against Gram-positive bacilli and cocci, including $S$. aureus. ${ }^{11}$

\section{Inhibitors of Cell Wall Biosynthesis}

The bacterial cell wall has several functions: to maintain the cell's shape; to provide a semi-permeable barrier; to counteract changes in the osmotic pressure of its environment; and to prevent digestion by host enzymes. ${ }^{1}$ All bacterial cell walls differ dramatically in structure and function compared to the outer layers of mammalian cells. Generally, enzymes found in bacterial cell walls are not found in mammalian cells, therefore making them attractive targets for chemotherapy of bacterial infections. There are two main classes of drugs that target the bacterial cell wall: $\beta$-lactams (penicillins, cephalosporins, carbapenems, and monobactams), (Figure 1.4) and glycopeptides (vancomycin), (Figure 1.5). Though they differ in their site and mechanism of action, both kill bacteria by disrupting the normal function the bacterial cell wall causing lysis. ${ }^{1}$

\section{$\beta$-lactams}

Penicillin $\mathrm{G}$ was the first natural product antibiotic, unlike the synthetic sulfonamides, to enter the market in the early 1940's. Its discovery began serendipitously in 1928 when Alexander Fleming noticed that an old agar plate originally inoculated with 


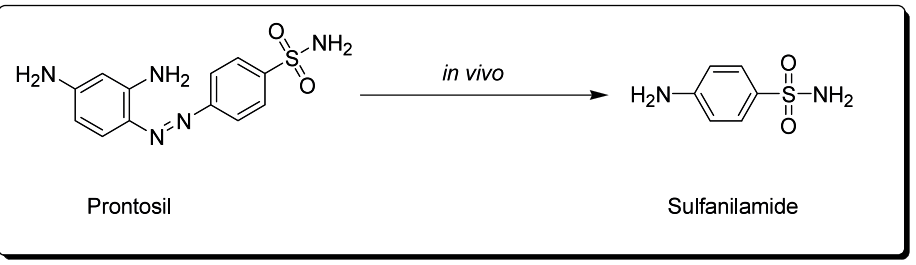

Figure 1.2: Prontosil and Its Active Metabolite, Sulfanilamide

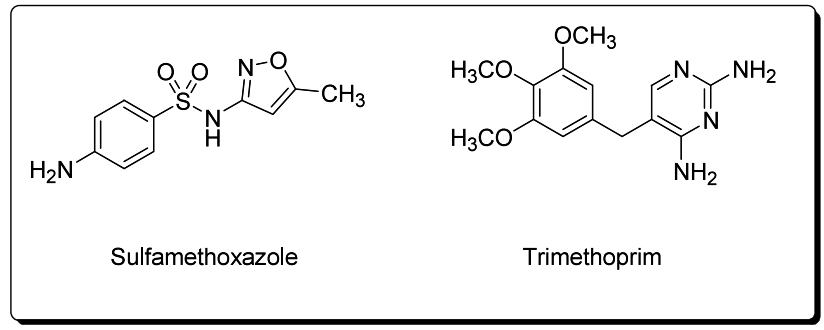

Figure 1.3: Structures of Inhibitors of the Folate Biosynthesis

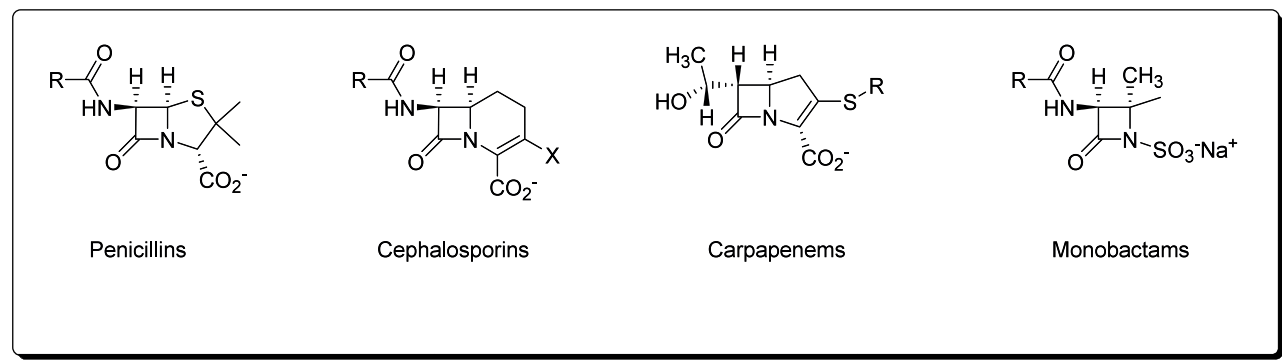

Figure 1.4: General Skeleton of the Four Classes of $\beta$-Lactam Antibiotics 


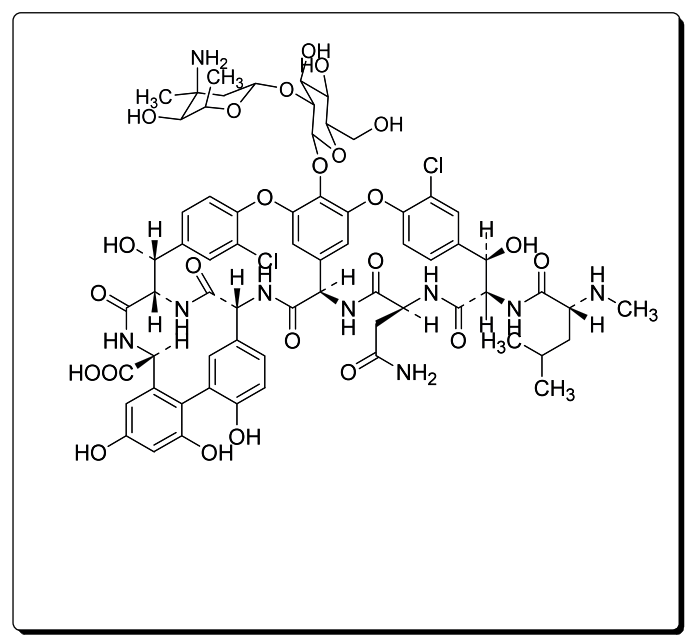

Figure 1.5: Vancomycin 
S. aureus was contaminated with a fungus. This mold produced a clear zone of lysed bacteria around its colony and Fleming hypothesized that the fungus was producing a substance that killed the bacteria. He identified this fungus as Penicillium notatum. Through many trials, Fleming was unable to isolate the active component from the mold and produce it in a stable form suitable to treat bacterial infections. ${ }^{12}$ Ten years later, Abraham, Chain, Florey, and Heatley, after considerable efforts, were able to identify the active component as a small molecule that they named penicillin. They were able to develop techniques to mass culture and isolate penicillin in a sufficient scale to prove its efficacy to treat topical and systematic infections. Further developments that followed by US researchers significantly increased the yield and scale of the manufacture of penicillin in time for its use during World War II. In 1945, Fleming, Florey, and Chain shared the Nobel Prize in Physiology and Medicine for their collective contributions to the discovery of penicillin.

The $\beta$-lactam class of antibiotics works by targeting penicillin binding proteins (PBPs), peptidoglycan transpeptidases, which catalyze the cross-linking of the peptidoglycan. They all contain an unstable electrophilic four-membered cyclic ring that reacts irreversibly with a key serine residue in the active site of the transpeptidase, blocking the binding of the natural substrate. ${ }^{13}$ This blockade results in the death of bacteria by producing weakened cell walls which after time lyse. Overall, these compounds gained attention as they had an increased spectrum and are bactericidal unlike sulfonamides which are bacteriostatic.

The need to improve the shortcomings, such as acid stability, in Penicillin G led to the discovery of semi-synthetic penicillins. 6-aminopenicillanic acid (6-APA), isolated from fermentation, is used as a starting material in the synthesis of various semi-synthetic penicillin analogs. ${ }^{14}$ Penicillins have the general structure seen in Figure 1.4, which contains a fused $\beta$-lactam- thiazolidine bicyclic ring structure. Alone, 6-APA has weak activity, but substitution on its primary amino group yields compounds with improved potency, oral bioavailability, antibacterial spectrum, and decreased sensitivity to $\beta$ lactamases, the enzymes responsible for inactivating $\beta$-lactams and preventing them from executing their mechanism of action.

Cephalosporin antibiotics were isolated from Cephalosporium acremonium and pursued as an alternative to treatment with penicillins because of their intrinsic activity against penicillin-resistant cultures. ${ }^{1}$ The active portion, 7 -aminocephalosporanic acid (7-ACA) which is analogous to 6-aminopenicillanic acid is used as a precursor for the development of semi-synthetic cephalosporins. ${ }^{15}$ Four generations have subsequently been developed with increasing coverage and $\beta$-lactamase stability. ${ }^{1}$

Carbapenem antibiotics were originally developed from thienamycin, a naturallyderived product of Streptomyces cattleya. ${ }^{16}$ They have an extremely intense and broadspectrum antimicrobial activity against Gram-positive and Gram-negative bacteria combined with the ability to inactivate $\beta$-lactamases. These drugs combine in one molecule the functional features of the best of the $\beta$-lactam antibiotics as well as the $\beta$ - 
lactamase inhibitors. Although they offer very potent broad-spectrum activity, they have poor oral bioavailability. ${ }^{1}$

Monobactams are monocyclic $\beta$-lactams isolated from Chromobacterium violaceum. ${ }^{17}$ These compounds inspired the synthesis of aztreonam, a totally synthetic monobactam with Gram-negative activity and ability to inactivate $\beta$-lactamases. ${ }^{18-22}$ It has a similar mechanism of action to other $\beta$-lactams with specificity to PBP3s. A major advantage of azetreonam is its low allergenicity when compared to other $\beta$-lactams.

\section{Glycopeptides}

Glycopeptides represent another class of compounds that disrupt cell wall synthesis. They inhibit the last stages of cell wall assembly by forming complexes with the terminal D-ala-D-ala of the peptidoglycan precursors preventing the cross-linking reactions catalyzed by transpeptidases, transglycosylases and carboxypeptidases. ${ }^{1}$ These compounds are considered the "drugs of last resort" since they have outstanding broad spectrum of activity (Gram-positive). Methicillin-resistant Staphylococcus aureus (MRSA) is in the most common hospital-acquired bacterial infection. Vancomycin (Figure 1.5) resistance remains low and vancomycin is still the drug of choice for the treatment of MRSA infections. ${ }^{23}$

\section{Inhibitors of Protein Biosynthesis}

This class of antibiotics exerts its effects by inhibiting ribosomally mediated protein biosynthesis. Bacterial ribosomes are made up of two subunits (30S and 50S), which contain suitable structural differences from the eurkaryotic ribosomes that allow these to be targeted for drug intervention. At normal doses, these antibiotics do not bind to nor interfere with the function of the human $80 \mathrm{~S}$ ribosomal subunits, a factor that explains the basis for their selective toxicity. It is found that interference with bacterial protein biosynthesis prevents repair, cellular growth, and reproduction and the effect, in clinically achievable doses, can be bacteriostatic or bactericidal depending on the class. ${ }^{1}$ Antibiotics that inhibit protein biosynthesis include aminoglycosides, tetracyclines, and macrolides among others; however the aforementioned antibiotic classes will be discussed as these represent the major classes of protein synthesis inhibitors.

\section{Aminoglycosides}

Streptomycin, usually used in treatment of tuberculosis (TB), was the first agent of this class to be introduced the market in 1944. Other agents in this class include kanamycin and gentamycin (Figure 1.6). The chemistry, spectrum, potency, toxicity, and PK of these agents are a function of the specific identity of the basic diaminoinositol unit and the arrangement and identity of the attachments that allows them to bind to the acidic RNA strands in the ribosome. ${ }^{1}$ These agents have an intrinsic broad antimicrobial spectrum with coverage against anaerobic, Gram-positive, and Gram-negative bacteria. However, due to their toxic side effects of ototoxicity and kidney tubular necrosis their 


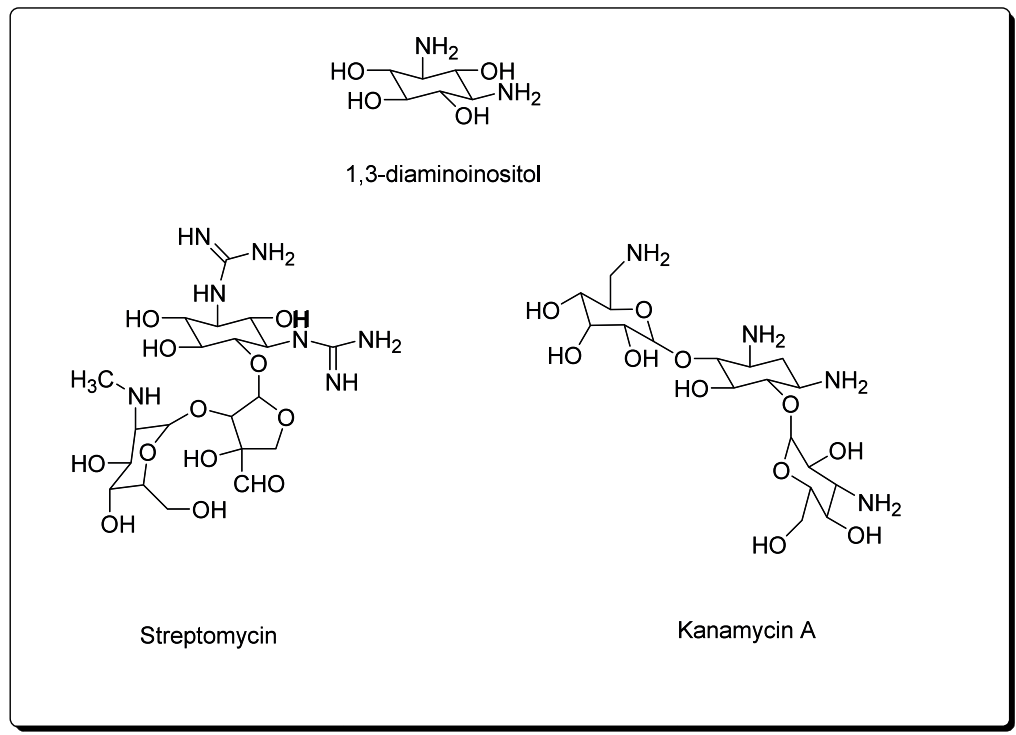

Figure 1.6: Aminoglycosides 
use is limited to severe infections by Gram-negative bacteria. ${ }^{24}$ These agents are bactericidal. They bind to the A-site on the 16S-ribosomal DNA portion of the $30 \mathrm{~S}$ ribosomal subunit interfering with the accurate recognition of tRNA by rRNA during translation. This leads to mistranslation of RNA templates and the subsequent selection of wrong amino acids ${ }^{1}$ thereby preventing the joining of the $30 \mathrm{~S}$ and $50 \mathrm{~S}$ subunits impairing protein synthesis.

\section{Tetracyclines}

As their name indicates, tetracyclines are composed of four fused six-membered ring systems. First in its class, chlorotetracycline, an isolate from an aerobic culture of Streptomyces aureofaciens, ${ }^{25,26}$ was introduced in 1948 (Figure 1.7). Tetracyclines are bacteriostatic agents exerting their effects by binding to the $30 \mathrm{~S}$ subunit inhibiting the binding of aminoacyltransfer-RNA to the ribosomes resulting in termination of peptide chain growth. They are broad spectrum antibiotics primarily used in the treatment of sexually transmissible bacterial infections. Tetracyclines have unfavorable side effects that prevent their use in children, such as staining of teeth and impairment of bone structure development. ${ }^{27}$

\section{Macrolides}

Erythromycin (Figure 1.8) was the first macrolide to be introduced to the market in 1955. Their name is derived from the characteristic large lactone ring. Macrolides act by inhibiting the translocation of aminoacyl tRNA following binding to the $50 \mathrm{~S}$ subunit. ${ }^{28}$ These compounds are bacteriostatic at therapeutic doses. Drug-drug interactions with macrolides are comparatively common and usually involve competition for oxidative liver metabolism by CYP3A4 enzyme. ${ }^{1}$ Macrolides are orally bioavailable, accumulate in macrophages and are anti-inflammatory in nature all positive factors for their use in therapy. ${ }^{29}$ They are mainly used for the treatment of upper and lower respiratory tract infections primarily caused by Gram-positive bacteria like Streptococcus pyogenes and S. pneumoniae. ${ }^{1}$

\section{Inhibitors of Nucleic Acid Biosynthesis}

There are two principal targets associated with this class of drugs: DNA gyrase and topoisomerase IV. DNA gyrase is responsible for introducing negative supercoils into DNA thereby allowing superhelical tension ahead of the polymerase to be released allowing replication to continue. ${ }^{30}$ Topoisomerase IV shares a similar function with DNA gyrase by also being responsible for relieving supercoils in DNA and allowing chromosome separation during cell division in Gram-positive bacteria. ${ }^{31}$ An analogous, yet structurally different enzyme, topoisomerase II, is present in eukaryotes. However, topoisomerase II does not bind fluoroquinolones which binds to the bacterial counterpart. Inhibition of DNA gyrase and topoisomerase IV interferes with cell growth and division leading to cell death (bactericidal). ${ }^{32}$ Though they have similar mechanisms 


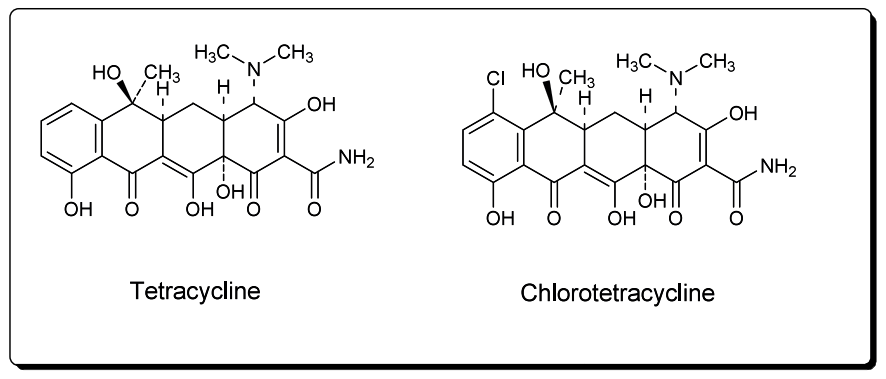

Figure 1.7: Tetracyclines

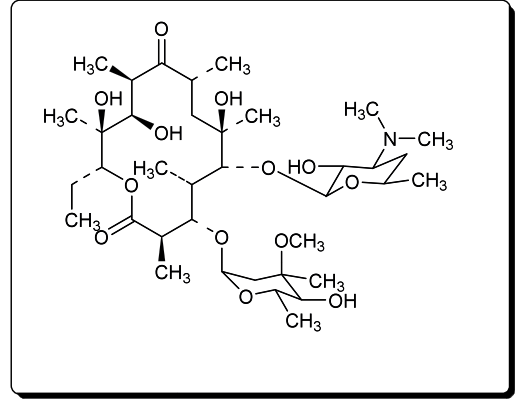

Figure 1.8: Erythromycin A 
topoisomerase IV is more important to some Gram-positive organisms and DNA gyrase to Gram-negative organisms.

Quinolone antibiotics comprise a group of synthetic substances that inhibit DNA gyrase and topoisomerase IV in bacteria. The first drug to be marketed in 1965 was nalidixic $\operatorname{acid}^{33}$ (Figure 1.9). It was primarily effective against Gram-negative bacteria and had high serum binding. ${ }^{1}$ The quinolones were not in wide clinical use until the discovery of the fluoroquinolones of which norfloxacin was the first to become important, introduced in $1986 .{ }^{34}$ The introduction of the fluoro group increased target affinity over 100 -fold. Norfloxacin is a broad spectrum agent with potency equivalent to earlier natural product derived antibiotics. ${ }^{34}$ Future generations (I- IV) of quinolones were introduced over the years based on their spectrum of activities. ${ }^{1}$ Particularly, ciprofloxacin, levofloxacin and moxifloxacin are more potent, well tolerated, with good oral bioavailability and hence are some of the most successful antimicrobial agents today.

Inhibitors of DNA-Directed RNA Polymerase

The rifamycin antibiotics are members of the ansamycin class of natural products produced by Streptomyces mediterranei. ${ }^{35-37}$ Semisynthetic derivatives, rifampin and rifapentine (Figure 1.10), were subsequently prepared having significant benefits over natural rifamycins with increased orally activity and spectrum of activity. ${ }^{1}$ The drugs are front line treatments for tuberculosis. These agents inhibit bacterial DNA-dependent RNA polymerase (DDRP) by binding to the $\beta$-subunit of the enzyme and are highly active against rapidly dividing intracellular and extracellular bacilli. ${ }^{1}$ Inhibition of DDRP leads to a blocking of the initiation of chain formation in RNA synthesis. The introduction of rifampin in 1967 reduced the duration of combination therapy for the treatment of tuberculosis from 18 to 9 months. ${ }^{1}$

\section{Resistance to Antibiotic Chemotherapy}

Antibacterial drug resistance is currently the most significant problem facing the clinical use of antibiotics. Resistance occurs when a formerly effective drug becomes no longer effective due to bacteria having acquired genetic changes causing resistance.

Resistance can either be intrinsic or acquired. Intrinsic resistance occurs naturally in the absence of selection pressure upon exposure to antibiotics. Bacteria have been around for over 3 billion years. Over time they have survived by equipping themselves with safety measures to conquer any toxicities. ${ }^{38}$ Acquired resistance occurs as a result of mutations that affect the structure of the drug target or acquisition of extrinsic DNA via transformation, transduction, or conjugation. The acquisition of foreign DNA is the most common and important mechanism as it accounts for much of the development of resistance in bacteria. ${ }^{39}$

Sulfa drugs and penicillins were the first drugs to reach the market in late 1930s and early 1940's, respectively and were thought to be the "wonder drugs" as they could 


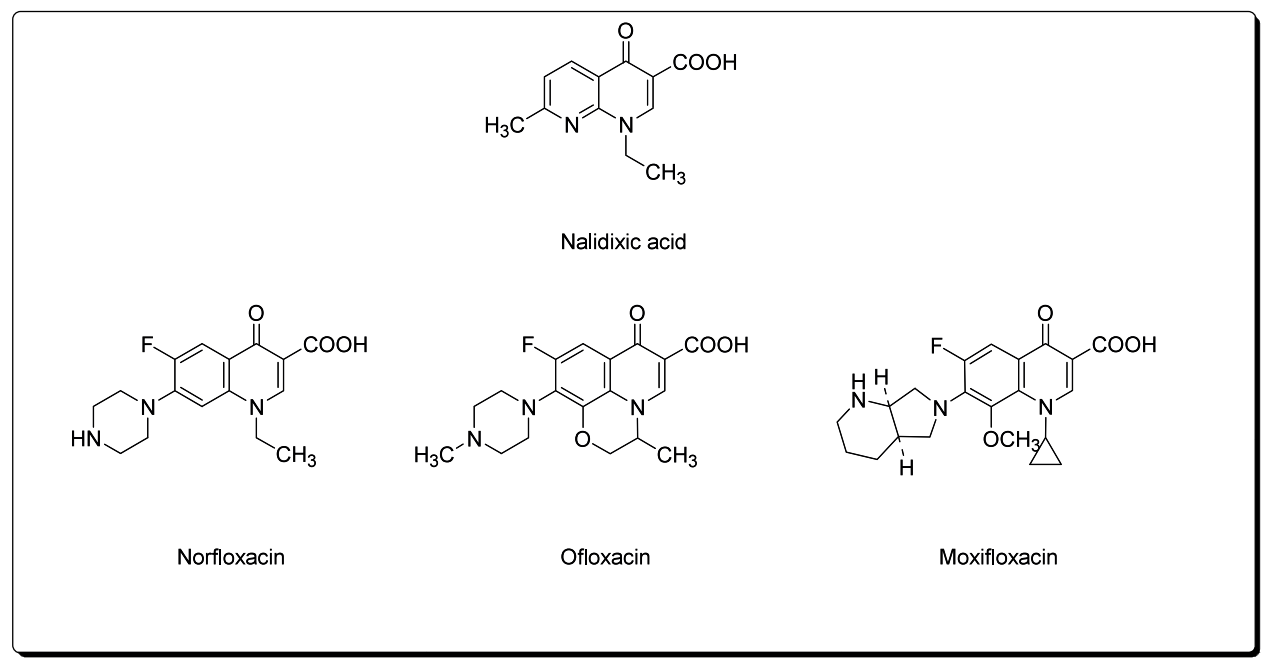

Figure 1.9: Quinolones

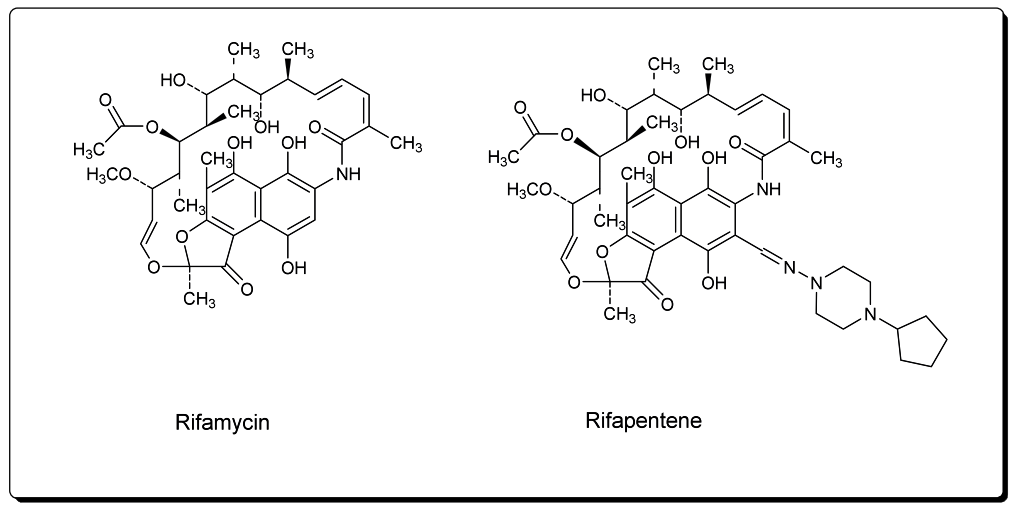

Figure 1.10: Rifamycins 
treat bacterial infections that were plaguing the world. However, the development of resistance surfaced shortly after. Some of the first reports involved reduced sensitivity of the sulfa drugs to several strains of pneumococci as observed by MacLean, Rogers, and Fleming. ${ }^{40,41}$ Thus far, bacteria have developed resistance to almost all antibiotics on the market today. Cross-resistance occurs when several bacteria develop resistance to different members of a group of chemically related compounds by the same resistance mechanism. This is exemplified as $\beta$-lactamases confer resistance to several different penicillins and cephalosporins. ${ }^{39}$ When bacteria become resistant to several unrelated bacterial agents by different resistance mechanisms they are considered to be multiplydrug resistant as observed with Mycobacterium tuberculosis and MRSA.

Generally, there are five major mechanisms with which bacteria exhibit antibiotic resistance: (1) restricted access of the antibiotic to its target by limiting uptake; (2) accelerated loss of antibiotic due to efflux pumps; (3) acquisition of enzymes that inactivate the antibiotic; (4) modification of the target; and (5) alternate pathway for formation of the products.

\section{Limiting Uptake}

Antibiotics must first reach their intracellular target before exerting their effects. The cell walls of Gram-negative bacteria differ from Gram-positive bacteria in that it has an outer membrane separating it from the cytoplasmic membrane in which many drug targets reside. ${ }^{42}$ This outer membrane is responsible for protecting the bacteria from harmful substances. Porins within the outer membranes allow molecules to enter into the cell to reach its site of action. Resistance occurs when mutations of the porin restrict the entry of antibiotics as seen with imipenem, a $\beta$-lactam antibiotic, in Pseudomonas. aeruginosa. $^{23,43}$

\section{Efflux Pumps}

Efflux pumps are important determinants of intrinsic and acquired resistance to antimicrobial agents. ${ }^{44}$ They work by quickly pumping drugs out of the cytoplasm before they have a chance to reach high enough concentrations to exert their effects.

Quinolones, macrolides, and tetracyclines are all classes of drugs that are susceptible to the same efflux pump. ${ }^{45}$ The first efflux mechanism to be discovered mediated resistance to tetracyclines in E. coli. ${ }^{4,46,47}$ Efflux is the primary mechanism of tetracycline resistance in Gram-negative pathogens, including Salmonella spp., Shigella spp., and Acinetobacter spp. ${ }^{44,45}$ via tet genes.

\section{Antibiotic-Altering Enzymes}

Several classes of antibiotics have enzymes whose role is to disrupt the function of the drug. The major mechanism of resistance in Gram-negative bacteria to $\beta$-lactam 
antibiotics is inactivation by $\beta$-lactamase, an enzyme that hydrolyzes the $\beta$-lactam ring thus preventing the $\beta$-lactam from binding to its target. $\beta$-lactamase resistance was first confirmed in the 1960 s against $S$. aureus. ${ }^{23}$ Currently, over $90 \%$ of $S$. aureus are resistant to penicillin as a result of $\beta$-lactamase production. ${ }^{39}$ Resistance to aminoglycosides is executed by modifying enzymes that inactivate antibiotics by $\mathrm{O}-$ phosphorylation, O-adenylation, or N-acetylation. ${ }^{48}$ These modifications change their overall structure compromising their binding to the ribosome. These drug destroying enzymes have been a key target in drug design, as will be described in the next section on overcoming resistance.

\section{Modification of the Target}

The most threatening mechanisms of resistance involve changes to the target site for antibiotic interaction; because it confers resistance to all compounds with the same mechanism of action. ${ }^{12}$ Modifications to target enzymes are the second most common form of resistance for antibiotics targeting the cell wall, especially for Gram-positive bacteria. Vancomycin resistance in enterococci is conferred by alteration of the peptidoglycan precursor pathway from D-ala-D-ala to D-ala-D-lac through the acquisition of multigene cassette. The new D-ala-D-lac has a lower binding affinity to the glycopeptides, producing resistance. ${ }^{49}$ Point mutations alter the affinity of quinolones to DNA gyrase and rifamycin to RNA polymerase. Resistance to the antibiotics that target folic acid synthesis arises from mutations to the active site of the drugs' target.

\section{Bypass Pathways}

Bacteria can develop a novel metabolic pathway that bypasses the effect of the antibiotic rendering the drug ineffective. ${ }^{12,50}$ Mupirocin, a drug widely used for the treatment of topical Gram-positive skin infections, kills bacteria by binding to isoleucyltRNA sythetases (IleRS) thereby inhibiting protein synthesis. ${ }^{51}$ The acquisition of an alternate IleRS enzyme confers high-level resistance to S. aureus. ${ }^{52}$ In addition, trimethoprim resistance usually involves a plasmid-mediated synthesis of altered DHFR enzymes with reduced affinity for this drug. ${ }^{50}$

\section{Overcoming Resistance}

There is significant concern that the continual rise in drug resistance will lead us back to the pre-antibiotic era with high fatality rates. This is particularly worrisome for organisms such as Pseudomonas, Acinetobacter and MRSA for which we already have few treatment options and could conceivably become completely untreatable. It is necessary to implement strategies to reverse or slow down resistance against current chemotherapies. These measures require joint efforts from the clinic, the public, and research arenas. The improper or overuse of antibiotics is the leading explanation for increases in antibiotic-resistant bacteria. ${ }^{44,53}$ Clinicians have to make sure that they are 
appropriately prescribing antibiotics for proper use. In turn, patients have to make sure they cooperate with current regimens to ensure resistant bacteria don't develop by noncompliance. Infection control is also very important as one in ten patients acquires an infection during their hospital stay. Better infection control could reduce the number of infections, reduce costs due to increased hospital stays, and limit the need for more antibiotics. ${ }^{38,53}$ Lastly, the research community is responsible for developing new agents to combat the emergence of antimicrobial resistance. The next section will describe the efforts that the research community has taken so far and where we have left to go.

\section{Inhibiting Drug-Destroying Enzymes}

The predominate mechanism of resistance to $\beta$-lactam antibiotics is $\beta$-lactamases. There are currently four recognized molecular classes of $\beta$-lactamases (Class A penicillinases, Class B metallo- $\beta$-lactamases, Class $\mathrm{C}$ cephalosporinases and Class D oxacillinases). ${ }^{54,55}$ The main focus has traditionally been to develop agents that are stable to hydrolysis by known $\beta$-lactmases or that irreversibly inhibit $\beta$-lactmases in which three, tazobactam, sulbactam, and clavulanate, are currently approved for use in the clinic (Figure 1.11). Unfortunately, these agents only work against Class A $\beta$ lactamases. ${ }^{55}$ There is ongoing work in the development of specific and broad spectrum $\beta$-lactamase inhibitors to work synergistically with current $\beta$-lactam antibiotics. ${ }^{56-65}$ One such recent discovery is NXL-104, a representative of a new class of potent inhibitors of class A and Class C $\beta$-lactamases with broad Gram-negative coverage ${ }^{65}$ (Figure 1.11).

Chemical inactivation of aminoglycosides, catalyzed by O-phosphotransferases, $\mathrm{O}$-adenyltransferases, and $\mathrm{N}$-acetyltransferases are the primary mode of resistance by compromising the binding of the drug to the target site. ${ }^{66}$ These enzymes are amenable to inhibition as inhibitors of adenyltransferases and acetyltransferases have been reported. ${ }^{67-}$ 69 "Unfortunately, only one, the 7-hydroxytropolone inhibitor (Figure 1.12) of an aminoglycoside-2"-O-adenyltransferase, actually demonstrated potentiation of aminoglycoside activity against resistant organisms expressing the corresponding

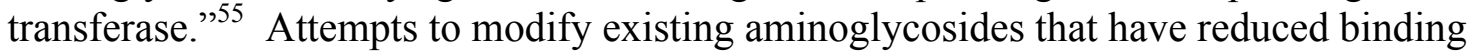
to corresponding modifying enzymes has been a more successful approach in the development of new antimicrobial agents for this class. ${ }^{55,70}$

\section{Inhibiting Multi-Drug Efflux Pumps}

In Gram-negative bacteria, resistance appears to be affiliated with limited access to the target site by multi-drug efflux systems. ${ }^{55}$ Fluoroquinolones and tetracyclines have resistance mechanisms involving efflux pumps. There have been extensive efforts in the discovery of efflux pump inhibitors. Inhibition of efflux pumps is expected to decrease the level of intrinsic resistance and significantly reverse acquired resistance. Reserpine (Figure 1.13), an inhibitor of the fluoroquinolone pump, NorA, has been described. ${ }^{71}$ Reserpine treatment of $S$. aureus and $S$. pneumoniae prevented emergence of fluroquinolone resistance in these organisms. Another inhibitor, MC-207,110 (Figure 


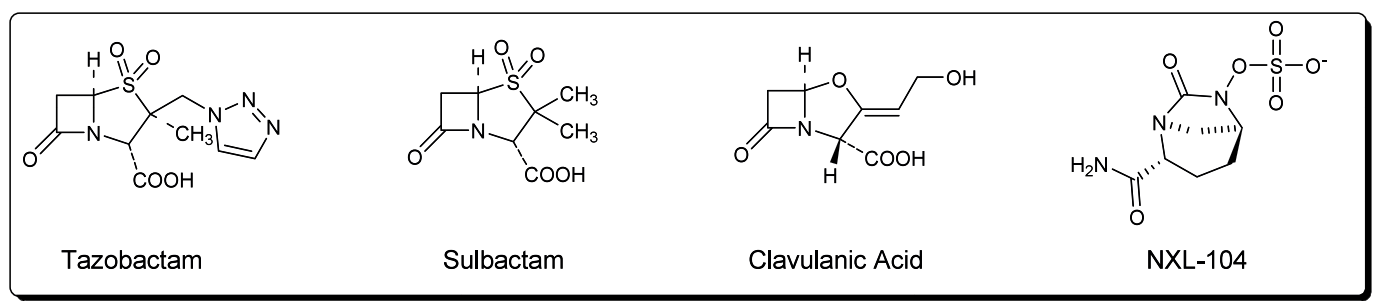

Figure 1.11: $\beta$-Lactamase Inhibitors

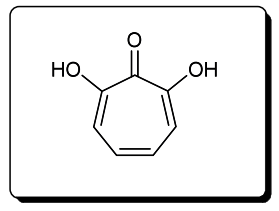

Figure 1.12: Inhibitor of Aminoglycoside-2"-O-Adenyltransferase

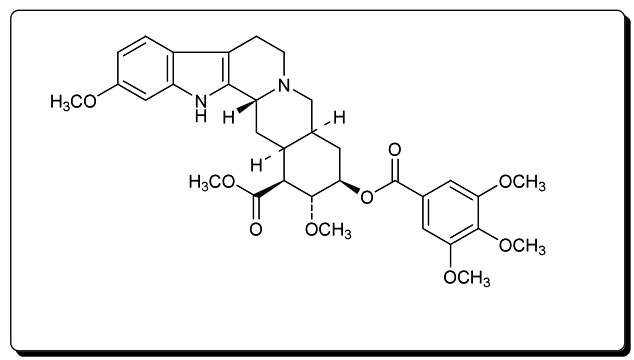

Figure 1.13: Reserpine, an Inhibitor of Multi-Drug Efflux Pumps 
1.14), discovered from a screen of natural product and synthetic compound libraries, has been described that potentiated the action of levofloxacin in P. aeruginosa. ${ }^{72-74} \mathrm{MC}$ 207,110 is active against several resistance-nodulation-cell-division (RND) pumps found in a variety of Gram-negative pathogens giving the potential for broad-spectrum efflux pump inhibitors. ${ }^{72}$ In addition, several teteracycline derivatives have been reported as inhibitors of tet efflux systems (Figure 1.15). Some inhibitors were found to work "synergistically with doxycycline against E. coli, S. aureus, and E. faecalis strains expressing efflux determinants of tetracycline resistance, while others acted as potent growth inhibitors of $S$. aureus expressing tet efflux. $" 55,75,76$

Introducing New Chemical Entities (NCE)

Oxazolidinones were the first new class of antibiotics to enter the market since the introduction of rifamycins in the 1970s. The first oxazolidinones were discovered by DuPont in the late 1970's. ${ }^{77}$ These compounds had significant activity against a wide range of Gram-positive sensitive and resistant strains of bacteria. However, they showed lethal toxicity in animal models, which suspended the work on these compounds. ${ }^{77,78}$ Pharmacia and UpJohn picked up this project in the early 1990's, which led to the discovery of Linezolid. ${ }^{77}$ Linezolid (Figure 1.16) is the first drug of its class to be introduced into the market in 2000. It is a purely synthetic antibiotic that is effective against a wide spectrum of Gram-positive bacteria, including MRSA and vancomycin intermediate $S$. aureus (VISA) for the treatment of nosocomial pneumonia, complicated skin infections. ${ }^{77}$ However, it still has limited duration of use due to side effects involving myeloid suppression. ${ }^{77,78}$ Its mechanism of action involves inhibition of protein synthesis (bacteriostatic) but at a stage different from that of other protein synthesis inhibitors. ${ }^{1}$ It binds to the bacterial $23 \mathrm{~S}$ ribosomal RNA of the 50S subunit, blocking the formation of a functional 70S initiation complex, which is essential in the bacterial translation process. $^{78}$

Daptomycin (Figure 1.17), a fermentation product produced by Streptomyces roseosporus, is a novel cyclic lipopeptide antibiotic used to treat infections caused by Gram-positive bacteria including multiple antibiotic-resistant and susceptible strains. ${ }^{79}$ FDA approval was granted in 2003 for the treatment of complicated skin and skin structure infections caused by Gram-positive bacteria. Its unique structure consists of a 13-member amino acid cyclic lipopeptide with a decanoyl side-chain conferring its novel mechanism of action. ${ }^{79}$ Its unique mechanism of inactivation involves insertion of daptomycins lipophilic tail into the membrane causing depolarization, resulting in the loss of membrane potential required for synthesis of DNA, RNA, and proteins. ${ }^{79}$ It has concentration-dependent bactericidal activity, but time-dependent side effects; therefore it is dosed at high concentrations on an infrequent basis. ${ }^{79}$

A less direct way of targeting resistance is to develop macrolides that overcomes or are less impacted by existing resistance mechanisms. Telithromycin (Figure 1.18), used to treat mild to moderate respiratory infections, is a member of a new class of agents termed ketolides. $^{80}$ It is a semi-synthetic derivative of erythromycin A containing a 14- 


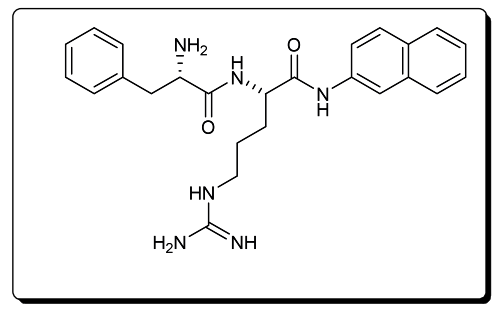

Figure 1.14: MC-207,110

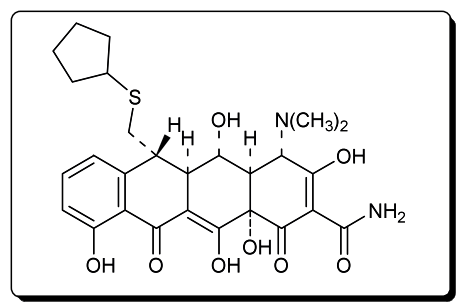

Figure 1.15: 13-CPTC

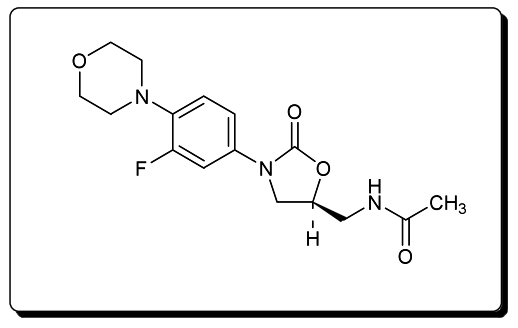

Figure 1.16: Linezolid

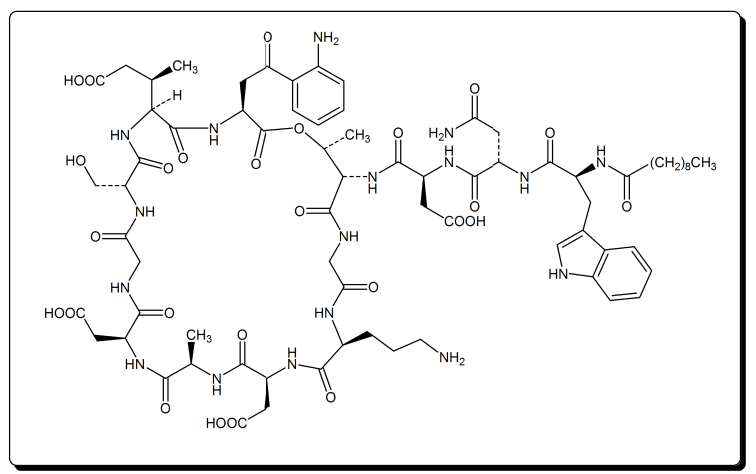

Figure 1.17: Daptomycin 


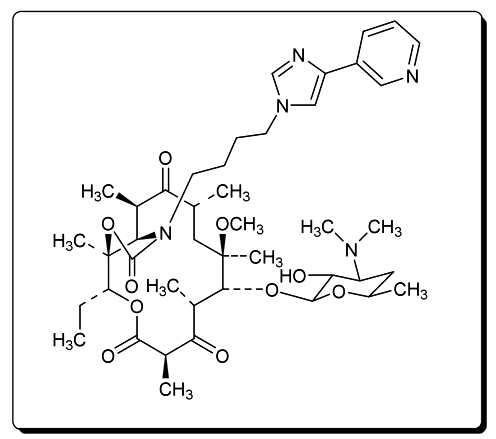

Figure 1.18:Telithromycin 
membered ring that lacks the cladinose sugar unit. Ribosomal methylation confers crossresistance to the macrolide-lincosamide-streptogramin $\mathrm{B}\left(\mathrm{MLS}_{\mathrm{B}}\right)$ antibiotics. ${ }^{80}$ The methylation leads to a conformational change in the ribosome, resulting in decreased affinity for all $\mathrm{MLS}_{\mathrm{B}}$ antibiotics. ${ }^{80}$ Ketolides with a carbamate, in replacement of the cladinose sugar ring, remain active against most resistant strains due to changes in the drug-binding site. ${ }^{80}$ Telithromycin shows increased activity against a number of Grampositive pathogens expressing efflux resistance. This new addition to the $\mathrm{MLS}_{\mathrm{B}}$ group was developed specifically for the treatment of community-acquired respiratory tract infections; however hepatotoxicity limits its use. ${ }^{80}$ Telithromycin was developed at Aventis (Romainville, France) and reached the market (Germany and Spain) as Ketek late in 2001. ${ }^{80}$ Its approval in the US wasn't granted until 2004. Similar to erythromycin, telithromycin is bacteriostatic targeting protein synthesis by binding to the $50 \mathrm{~S}$ subunit of the ribosome, blocking progression of the growing peptide.

Tigecycline (Figure 1.19) is the first commercially available member of the glycylcyclines, a new class of antimicrobial agents similar to tetracyclines, marketed by Wyeth in 2005 as a response to the growing antibiotic resistance seen in bacteria such as S. auerus. ${ }^{81,82}$ The glycyclines have potent Gram-positive, Gram-negative, and anaerobic activity, including certain multi-drug resistant strains. ${ }^{82}$ This antibiotic is a semisynthetic derivative of minocycline by the substitution of a 9-'butylglycylamido group at the 9 position on the D ring. ${ }^{81,82}$ Because of structural modifications, tigecycline is stable against the two main forms of tetracycline resistance: efflux pumps and ribosomal protection. Tigecycline displays distinct advantages as an antimicrobial agent and presents a new therapeutic option for the treatment of multi-drug resistant infections. ${ }^{81,82}$ It is bacteriostatic targeting the $30 \mathrm{~S}$ subunit on the ribosome inhibiting protein translation. This blockade prevents the entry of amino-acyl transfer RNA molecules into the A site of the ribosome, resulting in the loss of peptide formation. ${ }^{81-83}$ Tigecycline is indicated for the treatment of complicated skin and soft tissue infections and complicated intra-abdominal infections.

\section{Pursuing Novel Targets with Novel Modes of Action}

There is concern that resistance will rapidly develop to new agents that are derivatives of existing antimicrobial agents. ${ }^{83}$ One approach to overcome this problem is to develop new chemical entities, which has already been addressed above. Another approach involves the discovery and development of new compounds with novel modes of action while trying to avoid cross-resistance. Development of these new targets will less likely harbor pre-existing resistance mutations in their target since they have not been exposed to the natural selection pressure of antibiotics. Proof of concept exists with two agents currently on the market: mupirocin, a potent inhibitor of isoleucyl-tRNA synthetase; and isoniazid, an inhibitor of enoyl-ACP reductase in Mycobacterium tuberculosis. ${ }^{84}$

As briefly mentioned, mupirocin (Figure 1.20) is a member of the class of antibiotics that inhibit protein synthesis. ${ }^{52}$ It was isolated from Pseudomona 


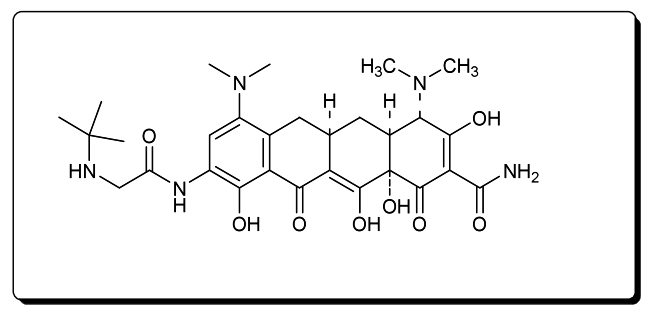

Figure 1.19: Tigecycline

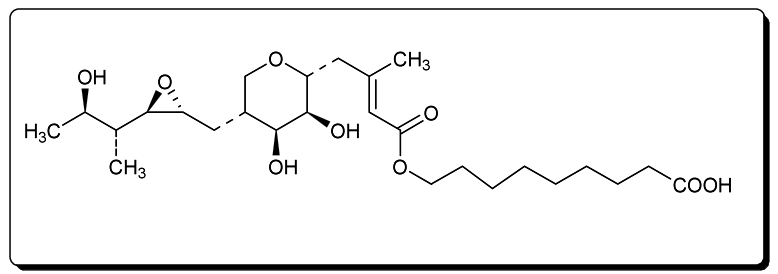

Figure 1.20: Mupirocin 
fluorescens ${ }^{85}$ for use as a topical agent to treat bacterial skin infections ${ }^{51}$, such as impetigo caused by Gram-positive bacteria. Mupirocin selectively binds to bacterial isoleucyl-tRNA synthetase, which prevents the incorporation of isoleucine into bacterial proteins. Because its mechanism of action is unique, it has few problems with crossresistance. ${ }^{51}$ Since the discovery of this target with its unique mechanism of action, much work has been done on the discovery of new aminoacyl-tRNA synthetase (aa-RS) inhibitors as potential antibiotics. ${ }^{86,87}$ Aa-RSs represent ideal targets for drug design because (1) they are essential for survival of bacteria; (2) there are major differences in the human and bacterial enzymes that enable the development of compounds with selective toxicity; (3) they are highly conserved across many bacterial species providing the possibility of broad spectrum antibiotics; (4) their properties are amenable to highthroughput screening; and (5) there exists several distinct enzymes for development of discrete antimicrobial agents. ${ }^{86,87}$

Fatty acid synthesis (FAS) enzymes are essential to the vitality of bacteria, therefore providing a suitable target for antimicrobial drug design (Figure 1.21). ${ }^{88}$ The bacterial FAS-II pathway, in which each step is performed by individual enzymes, differs from the multi-enzyme FAS-I complex found in mammals and are highly conserved across many bacterial species giving rise to their potential for the development of broad spectrum antibiotics. ${ }^{89-92}$ Isoniazid, discovered in 1952 is used as a first-line agent in the treatment of tuberculosis. It is a prodrug that must be activated, and then reacts with NADH to form a complex that binds tightly to one of the bacterial fatty acid enzymes, keto-enoylreductase (InhA), a homologue of the E.coli enoyl-ACP reductase (FabI) enzyme, blocking the access of the natural substrate. ${ }^{91}$ Triclosan, an inhibitor of enoylACP reductase I, is used as a consumer antibiotic incorporated into a plethora of household products. ${ }^{89}$ Apart from these clinically used agents, several other potent inhibitors have been discovered with proven efficacy which include cerulenin, thiolactomycin, and the diazoborines. ${ }^{91}$ Cerulenin and thiolactomycin are potent natural product inhibitors of the 3-keto-ACP synthetases (KAS) and the diazoborine derivatives are inhibitors of enoyl-ACP reductase. Over the past years, there has been extensive efforts to develop novel antimicrobial agents targeting fatty acid biosynthesis using natural product screening, structure-based drug design, and compound library screening that have led to clinical candidates, such as API-1252 $2^{93}$ and CG400549 94 that target FabI (Figure 1.22). ${ }^{90}$

The targets mentioned above came before the introduction of the new genomic era, which appeared in 1995 after the publishing of the complete genome sequence of Haemophilus influenzae. ${ }^{95}$ Since then over 200 bacterial genome sequences have become available. Genomics has promised to provide a plethora of novel targets and hence a flood of new therapeutic agents. ${ }^{84}$ Ideally, a target for antimicrobial drug design must be essential to the survival of the bacteria and have no close homolog in the human genome. Genomics does not work alone as other technologies are required. In the next section will describe how medicinal chemists use the information from genomics to develop new antimicrobial agents. 


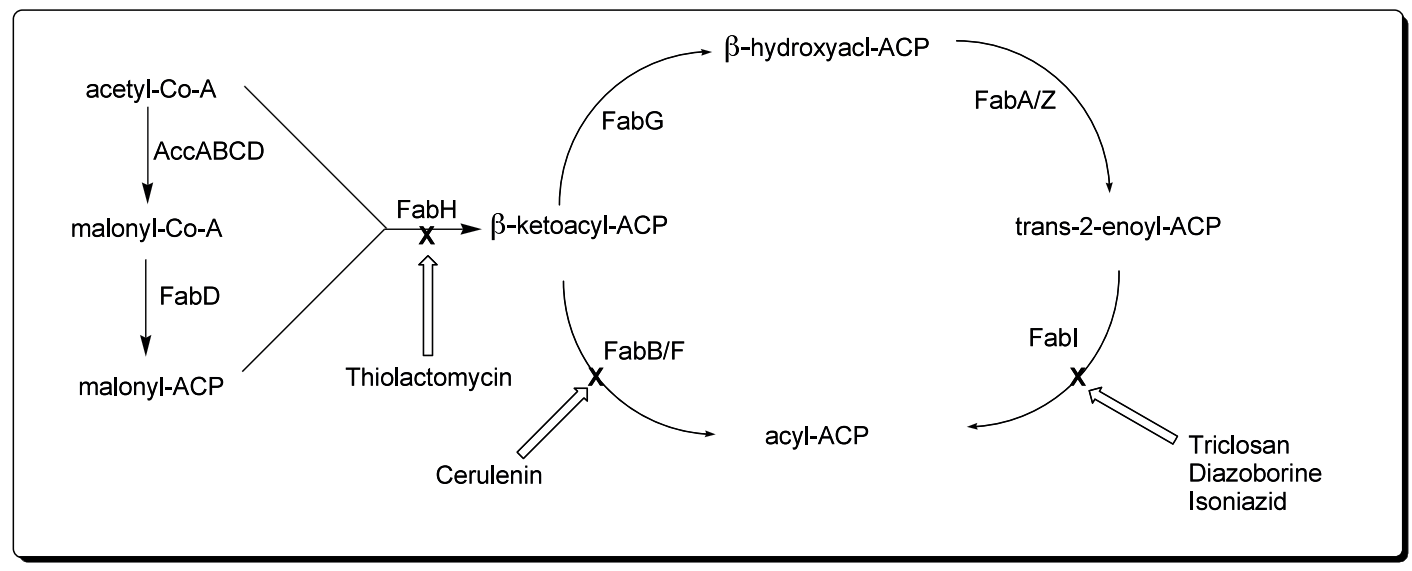

Figure 1.21: Fatty Acid Biosynthesis

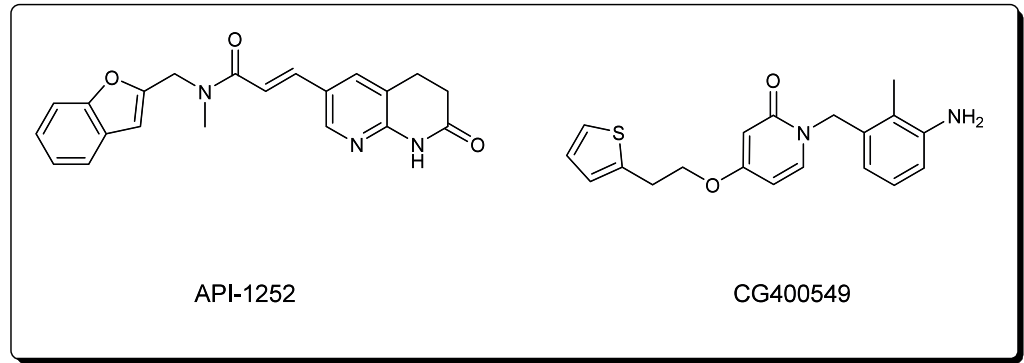

Figure 1.22: Clinical Candidates that Inhibit Bacterial Fatty Acid Synthesis 


\section{Medicinal Chemistry Applications in Antimicrobial Drug Discovery}

A medicinal chemist involved in drug discovery requires a highly interdisciplinary environment combining organic chemistry, biochemistry, computational chemistry, pharmacology, pharmacognosy, and molecular and structural biology. ${ }^{96}$ This section will discuss the use of medicinal chemistry techniques in the drug discovery process which include: structure-based drug design for lead discovery and optimization; combinatorial chemistry techniques for lead optimization; and the importance of druglikeness during the lead optimization process.

\section{Structure-Based Drug Design}

The first project, which is outline in Chapter 2, made use of structure-based drug design (SBDD) techniques in the discovery of potential inhibitors of Mycobacterium tuberculosis cell wall biosynthesis. SBDD involves the use of structural knowledge of proteins or other macromolecules to assist in the development of new drug candidates. It represents the idea that you can see exactly how your molecule interacts with its target protein. X-ray crystallography remains the gold standard for structure elucidation, affording high precision and the ability to look at complex systems. ${ }^{97}$ In drug design, it is desirable and most effective when a high resolution co-crystal structure of a receptor with a ligand bound is available as it gives the most structural information regarding how the ligand interacts in solution with the receptor. NMR and homology modeling offer alternative routes to structure based design. ${ }^{97}$ Structure-based design can be applied in a variety of ways once a structure is available: (1) identification of chemical starting points for lead optimization; (2) docking of commercial or virtual compounds; or (3) de novo design. It is an enrichment tool in medicinal chemistry, aiding the chemist in the prioritization of compounds throughout the lead optimization process. ${ }^{97}$ An early example of structure-based design was of trimethoprim analogs with significantly improved affinities to DHFR. However, the trimethoprim analogs could not be optimized to become drugs for human therapy. ${ }^{98}$ The first success story in structure-based design was the antihypertensive drug, captopril (Bristol-Myers Squibb). ${ }^{98}$

SBDD can be approached in two ways: receptor based design or ligand-based design. My project mostly involved the receptor-based approach which involves the use of structural knowledge of the target site to design drug-like molecules with specific binding activity. Virtual screening (VS) and docking are often methodologies used in receptor-based design. Virtual screening is a term used to describe the process of computationally analyzing large compound collections in order to prioritize compounds for synthesis or assay. Virtual screening can be used with or as an alternative to highthroughput screening (HTS). The major difference between HTS and virtual screening involves the use of tangible compounds and targets in HTS versus the in silico generated compounds and targets in virtual screening. Virtual screening has been used mainly in two ways: to find new compounds for drug design and also to improve current leads in hopes to find better drugs. Docking is often used in conjunction with virtual screening. This strategy requires a 3-D database of ligands, a 3-D structure of the target receptor, 
either derived experimentally or from a homology model, and a docking code comprising an efficient searching algorithm with an accurate scoring function. ${ }^{99}$ In this process large databases of compounds are "fit" into the active site of the enzyme and the interactions are scored. The compounds in a given conformation that "fit" best are ranked highest with a scoring function. These highest ranked compounds are often those chosen for synthesis or assay.

The ligand-based approach makes use of known receptor ligands and their structure-activity relationship (SAR) to form hypotheses about the target site. Quantitative structure activity relationship (QSAR) is a well known ligand-based approach currently used in drug design when the structural information about the target is missing. ${ }^{12}$ Three-dimensional QSAR shows the relationship between biological activity of a molecule and its geometric and chemical characteristics. ${ }^{12}$ Comparative molecular field analysis (CoMFA) and comparative molecular similarity indicies (CoMSIA) are 3DQSAR methods that search for relationships between the biological activity of a set of compounds (with specific alignment) and their 3-D electronic, steric, and hydrophobic properties. ${ }^{12}$ QSAR allows you to predict properties and activities of untested molecules based on preexisting molecules; optimize the properties of a lead compound; generate hypotheses about the characteristics of a receptor binding site; and prioritize compounds for synthesis or screening. ${ }^{12}$

\section{Combinatorial Chemistry and HTS}

Traditional synthesis involved one compound at a time, which was very time consuming. In order to get a drug to market, many compounds during the optimization stages need to be made. At the rate of one compound at a time, the time to market could be extended beyond the current 10-15 year mark. One way to improve the output came with the methodology of combinatorial chemistry. Combinatorial chemistry involves the synthesis of large structurally distinct chemical libraries of molecules for screening in the lead discovery or lead modification process. ${ }^{12}$ Unique to combinatorial chemistry is the synthesis of a wide range of analogues synthesized under the same conditions in the same reaction vessel. This technology has allowed scientist to synthesize many compounds quickly and at a reduced cost. Combinatorial chemistry was initially designed for peptide libraries, but has moved on to small compound synthesis, especially for discovery of new antimicrobial agents. ${ }^{12}$ All combinatorial library methods involve three main steps: preparation of the library, screening of the library components, and determination of the chemical structures of active compounds. ${ }^{100}$ Libraries are prepared in a systematic and repetitive fashion by the assembly of building blocks to give a diverse array of molecules with a common scaffold. ${ }^{12}$ They are carried out on solid support (one compound per bead). This is advantageous in that excess reagents can be used to drive the reactions to completion and isolation and purification of the products can be done by simple filtration and washing. ${ }^{12}$ Though combinatorial chemistry is advantageous in producing large numbers of compounds for screening, it has a bottle neck involving deconvolution of the active compounds. Since many compounds are often synthesized in one well, it is often difficult and time consuming to determine exactly which compound is active. Alternative 
strategies involve the synthesis of individual compounds in separate vessels called parallel synthesis. ${ }^{12}$ Parallel synthesis usually involves the use of solution phase synthesis using solid phase reagents such as scavenger resins or solid support reagents. ${ }^{100}$ In this strategy, compounds can be synthesized in parallel incorporating different sets of commercially available building blocks to provide a large number of diverse structures. This methodology has become the dominant method for high-throughput synthesis today.

Traditionally, many drugs on the market today were discovered serendipitously from the screening of natural products, namely from plants, animals, or fermentation or from synthetic compound libraries. ${ }^{100}$ A complementary method to combinatorial chemistry in the 1990s involved high-throughput screening (HTS). HTS is an in vitro screen, developed around 1990, that is capable of screening large libraries of compounds in hopes to discover hit molecules for lead development. ${ }^{100}$ As previously mentioned, HTS it is an alternative to or used in combination with virtual screening. HTS can be carried out robotically on small amounts of compound allowing for screening of large numbers of compounds. ${ }^{12}$ The overall idea theoretically should produce a great number of hits therefore providing more leads. As technology has improved screening in 96-well plates has moved to 1536 - well plates allowing for rapid development. ${ }^{100}$ The hit libraries can come from a number of sources including combinatorial chemistry libraries as discussed previously.

\section{Filters for Drug Likeness}

Absorption, distribution, metabolism, excretion, and toxicity (ADMET) characteristics of compounds are very important because a large percentage of drug candidates that reaches clinical trials are discontinued as a result of ADMET problems. If these properties can be predicted early in the drug discovery process, much time and expense would be saved in designing, synthesizing and testing compounds. ${ }^{12}$ Druglikeness is now widely used to filter out compounds likely to have poor pharmacokinetic (PK) properties early on in drug discovery. Christopher Lipinski and co-workers at Pfizer studied the physical properties of orally active compounds in the World Drug Index (WDI). ${ }^{101}$ From this study he developed the "rule of five" which is often used to determine what compounds would be likely drug candidates for further development. This guide was used to improve oral bioavailability during lead modification which was based on a large database of known drugs. The "rule of five" states that in order to have drugs that will have good absorption or permeation the following properties should exist: (1) molecular weight $<500$ Daltons; (2) calculated Log P (octanol/water partition constant) $<5$; (3) molecule should have $\leq 5$ hydrogen-bond donors (consisting of $\mathrm{OH}$ and $\mathrm{NH}$ groups); and (4) molecule should have $\leq 10$ hydrogen-bond acceptors (consisting of $\mathrm{N}$ and $\mathrm{O}$ atoms). There are a few orally available therapeutic classes with several drugs outside the 'rule of 5': antibiotics, antifungals, vitamins and cardiac glycosides. ${ }^{12}$ Generally speaking, these classes tend to be the exception to the rule because they have active transporters to carry them across membranes. Other predictors of good oral bioavailability include number of rotatable bonds $(\leq 7)$ and a low polar surface area 
$\left(<140 \AA^{2}\right){ }^{102,103}$ Using such filters early in drug discovery proved to cut down on time and cost of producing a drug to pre-clinical trials.

Lead-likeness has been a new concept adopted in the past few years. It considers smaller compounds or fragments that can be modified to enhance effectiveness during lead optimization. Fragments are small organic molecules (100-250 Da) that exhibit low binding affinities against target proteins, and, as such, would not usually be identified by HTS. ${ }^{104}$ Once a hit has been identified in this way, and its exact binding mode elucidated, the fragment could provide a novel template that can be developed into a more complex, higher potency ligand. Despite the low affinity of these small molecule hits, fragments tend to exhibit high 'ligand efficiency,' a high value for the average free energy of binding per heavy atom. ${ }^{104}$ This property makes fragments attractive starting points for iterative medicinal chemistry optimization. It is apparent that a lead, with respect to its properties, differs significantly from a drug. For this reason, Congreve and workers ${ }^{104}$ developed another set of rules to develop a lead fragment called the "rule of 3." This rule states that a fragment lead molecule should have the following properties: (1) molecular weight $<300$; (2) calculated $\log \mathrm{P}<3$; and (3) molecule should have $<3$ hydrogen bond donors and/or acceptors. These numbers are lower, because often times groups are added to a lead compound to improve activity, therefore starting smaller will avoid surpassing Lipinski's rules. Again, these rules don't work for all drugs, but is often the rule of thumb of small molecule drugs.

\section{Research Objectives}

In the continuing efforts for the discovery of novel candidates in the treatment of bacterial infections, two targets have been exploited: (1) the biosynthesis of rhamose, a key sugar residue in the cell wall of Mycobacterium tuberculosis; and (2) the biosynthesis of phosphatidic acid, a key intermediate in the synthesis of phospholipids in bacteria.

Sulfonamide Libraries as Inhibitors of Mycobacterium tuberculosis Cell Wall Biosynthesis

Chapter 2 deals with the design, synthesis, and biological evaluation of bi-aryl sulfonamide libraries as potential anti-tuberculosis drugs. We targeted rhamnose biosynthesis, a key sugar residue in the makeup of the mycobacterium cell wall. The libraries were based on a hit pyrazolone compound from a high-throughput screen performed by our collaborators at Colorado State University. I will describe our work using a structure-guided library approach, in which large virtual libraries against the target enzymes were generated and filtered, based on pharmacophoric and structural constraints, to produce smaller and more structurally complex libraries prioritized for synthesis. Several methods were evaluated to prepare for the parallel synthesis of the target sulfonamide libraries. After optimization, these libraries of sulfonamides were

synthesized and screened for inhibition of M. tuberculosis cell wall biosynthesis and for 
anti-tuberculosis activity. In this study, several sulfonamide inhibitors were discovered with plans to obtain co-crystal structures for future library developments.

Discovery of Novel Inhibitors in Phospholipid Biosynthesis

Chapter 3 deals with the importance of the development of new antimicrobial agents to overcome resistance problems seen with Gram-positive bacteria. As previously mentioned, one way to overcome resistance is to develop new drugs for novel targets. This approach should slow down resistance, and because it is novel should also avoid cross-resistance. This work targets the newly discovered PlsX/PlsY pathway to phospholipids biosynthesis in Gram-positive bacteria. I will describe the design, synthesis, and evaluation of stable substrate-based mimics that led to the discovery of the first known inhibitors for the PlsX/PlsY system. Compounds from this study showed significant enzyme inhibition activity at $S$. pneumoniae and $B$. anthracis as well as significant anti-anthrax activity. 


\section{CHAPTER 2: STRUCTURE-GUIDED SULFONAMIDE LIBRARIES AS INHIBITORS OF MYCOBACTERIUM TUBERCULOSIS CELL WALL BIOSYNTHESIS}

\section{Introduction to Tuberculosis}

The bacterium, Mycobacterium tuberculosis, is the causative agent of human tuberculosis (TB). It was first described in 1882 by Robert Koch, who subsequently received the Nobel Prize in physiology or medicine for this discovery in $1905 .{ }^{105,106} \mathrm{~TB}$ is a respiratory tract infection that is transmissible through aresol droplets resulting from coughing, sneezing, speaking, etc. ${ }^{107}$ The risk of transmission of the disease is higher for children who are still developing a healthy immune system and for individuals with disorders that impair immunity, such as the human immunodeficiency virus (HIV). Although TB most commonly attacks the lungs, it can also affect the central nervous system, the lymphatic system, the circulatory system, bones, joints, and even the skin. ${ }^{107}$ There are two general stages of the disease: latent TB and active TB. ${ }^{108,109}$ Individuals with the latent form of TB are generally asymptomatic and not contagious. In contrast, individuals with active TB display symptoms and are contagious. Not everyone infected with the tubercule bacilli develops the full-blown disease. Only about 5-10\% of individuals who have the latent infection will progress to the active TB disease during their lifetime, unless the patient becomes immunosuppressed, such as with HIV, which produces a reactivity rate of $10 \%$ per year. ${ }^{110}$ According to the World Health Organization (WHO), tuberculosis is the second leading cause of deaths from infectious diseases in the world second to HIV. ${ }^{111}$ Tuberculosis is a leading killer among HIVinfected people; about 200,000 people living with HIV/AIDS die from TB every year, most of them living in the sub-Saharan African region. ${ }^{111}$ Over one-third of the world's population ( 2 billion people) is infected with TB bacilli with an estimated 1.5 million deaths in $2006{ }^{111}$

\section{Tuberculosis Treatment}

Once a person has developed and is diagnosed with active TB, chemotherapeutic agents are required for treatment. Prior to the introduction of streptomycin in the 1940s, there was no effective treatment for tuberculosis. ${ }^{107}$ Now, treatment of the active form of TB generally utilizes rifampicin (RIF), isoniazid (INH), pyrazinamide (PZA), streptomycin (SM), and ethambutol (EMB), which are first-line agents ${ }^{107}$ (Figure 2.1). However, owing to the nature of TB's slow growth and ability to manifest in a latent state, the regiment for treatment is usually 6-9 months to completely eliminate the bacteria from the body. ${ }^{107}$ With the current drugs being used, regimens shorter than 6 months are not acceptable due to high relapse rates. ${ }^{112}$ The current treatment consists of a 2-month initial bactericidal phase of the daily use of INH, RIF, PZA, and SM or EMB to rapidly eliminate the bulk of tubercle bacilli. ${ }^{107}$ Pyrazinamide and rifampicin is crucial for the first 2 months of therapy, since they are active against latent phases of the infection. ${ }^{107}$ During the second 4 to 7 month sterilizing phase, patients take INH and RIF 


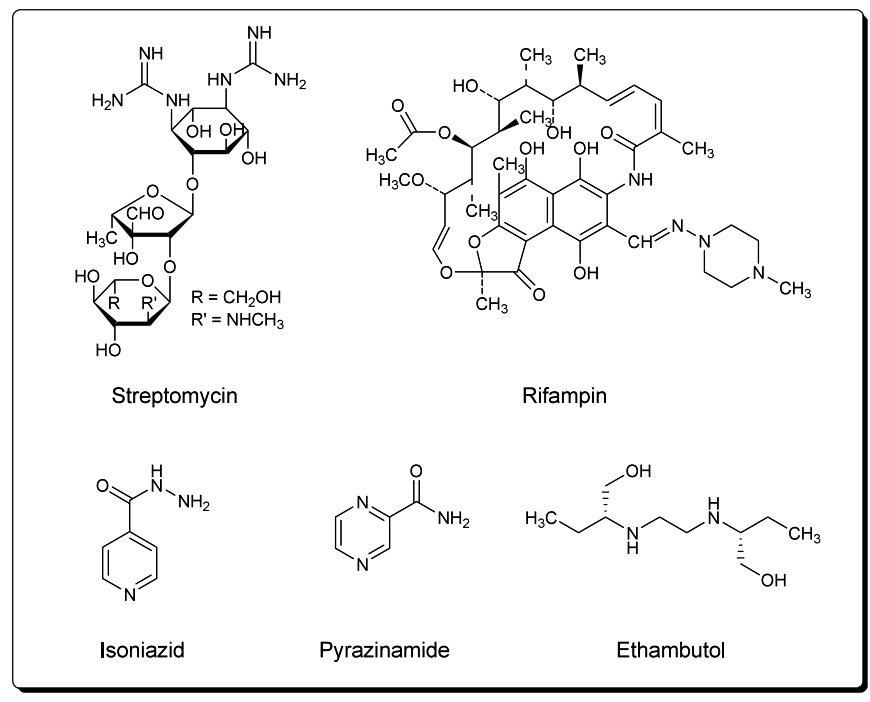

Figure 2.1: First-Line Tuberculosis Treatment 
to eliminate remaining bacilli. ${ }^{113}$ Second-line agents (Figure 2.2), including ethionamide, para-aminosalicyclic acid, cycloserine, capreomycin, and kanamycin, are generally utilized in cases of resistance, retreatment, or intolerance to first-line drugs. ${ }^{1}$ While these drugs are active against TB bacilli in vitro, they usually are less tolerated having higher incidences of adverse side effect, and are less effacacious requiring longer therapy for cure rates. ${ }^{1}$

\section{Isoniazid}

Isoniazid is an orally active synthetic antibacterial agent that was discovered in the mid 1900s to be an effective anti-tuberculosis drug. INH's bactericidal effects are exerted only against the actively growing organisms. ${ }^{107} \mathrm{INH}$ is known to disrupt cell wall biosynthesis by binding to one of the condensing enzymes (Inh A) in the fatty acid biosynthesis pathway. ${ }^{114,115}$ It is a prodrug that is activated by catalase-peroxidase enzyme (katG) to for the activated radical acyl anion. This form react with NADH to form a complex that binds tightly to InhA inhibiting the synthesis of critical mycolic acids of the mycobacterial cell wall. ${ }^{114}$ Resistance to INH is generally associated with mutations that inactivate the $k a t \mathrm{G}$ gene. ${ }^{116,117}$

\section{Rifampin}

Rifampin is an orally active, highly effective semi-synthetic antibiotic, derived from Streptomyces mediterranei. ${ }^{37}$ It is bactericidal against all populations of mycobacteria. ${ }^{107}$ Rifampin inhibits the $\beta$-subunit of RNA polymerase of the mycobacterium thus preventing transcription of DNA to RNA and the subsequent translation of proteins. Resistance develops when a mutation occurs in the gene responsible for the $\beta$-subunit of the RNA polymerase (rpoB gene $)^{118}$ resulting in inability of the antibiotic to readily bind to the RNA polymerase. The introduction of rifampin to the standard regimen significantly reduced TB treatment by half (18 to 9 months). ${ }^{107}$

\section{Pyrazinamide}

Pyrazinamide is an oral synthetic pyrazine analog of nicotinamide. It is bactericidal on actively replicating bacteria. Its activity is $\mathrm{pH}$ dependent with good in vivo activity at $\mathrm{pH} 5.5$ but nearly inactive at neutral $\mathrm{pH} .{ }^{1}$ Like INH pyrazinamide is a prodrug that uses pyrazinamidase to convert it to its active form, pyrazinoic acid, which inhibits fatty acid biosynthesis. ${ }^{119}$ Pyrazinamide is beneficial in that it is active against semi-dormant bacilli resulting in acidic environments that are not affected by other drugs. ${ }^{1}$ It is often used during the first 2 months of chemotherapy to reduce the total overall length of therapy. The introduction of PZA reduced treatment from 9 months to 6 months. ${ }^{107}$ The major serious side effect is the potential for hepatotoxicity. ${ }^{1}$

\section{Ethambutol}

Ethambutol is a bacteriostatic agent that inhibits arabinogalactan biosynthesis, a key component of the mycobacterial cell wall. ${ }^{120,121}$ It disrupts cell wall biosynthesis 


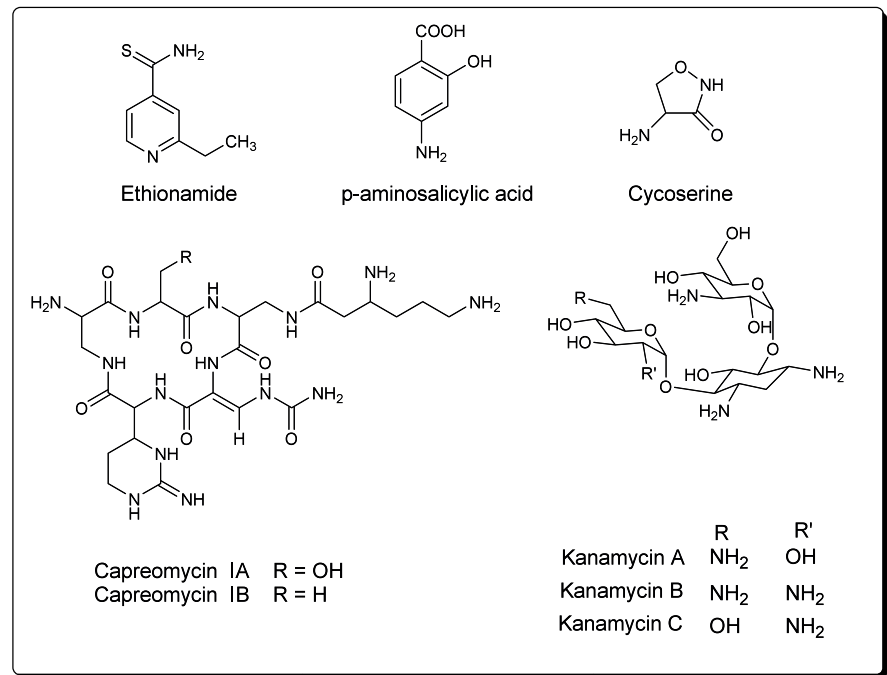

Figure 2.2: Second-Line Tuberculosis Treatment 
allowing better entry of other drugs to rapidly growing tubercule bacilli producing better killing by those agents. Ethambutol resistance involves a gene over expression and mutations of arabinosyl transferase which is controlled by the embB gene. ${ }^{122,123}$

\section{Streptomycin}

Streptomycin belongs to the aminoglycoside family of antibiotics. It was the first aminoglycoside to enter the market in 1944. ${ }^{1}$ It is a bacteriostatic agent used in the treatment of drug resistant TB. ${ }^{107}$ Streptomycin stops bacterial growth by inhibiting protein synthesis. Streptomycin is the only first-line agent that is given intramuscularly, which is associated with significant pain and is therefore not favored by patients. ${ }^{107}$

Need for New Therapeutic Agents

In the last 35 years there have been no new drugs to replace the current first-line agents. Even though these chemotherapeutic agents are effective, there are still problems in treating tuberculosis including poor patient compliance and multiple-drug resistance. ${ }^{107}$ As mentioned previously, the current treatment regimen usually lasts 6-9 months due to the time it takes to kill the latent and slow-growing bacteria. A daily regiment of 4 drugs over this time period can lead to patience non compliance which in turn can lead to the development of resistance against the first-line agents. Drug-resistant TB is a public health issue in many developing countries, as treatment is longer and requires more expensive drugs. ${ }^{111}$ The emergence of multi-drug resistant TB (MDR-TB) occurs when drug-susceptible tuberculosis is improperly or incompletely treated. According to WHO, MDR-TB is defined as resistance to the two most effective first line TB drugs: rifampin and isoniazid. ${ }^{111}$ When a person is resistant to any fluoroquinolone, and at least one of three second-line drugs (capreomycin, kanamycin, and amikacin), in addition to MDRTB they are said to have extensively drug-resistant TB (XDR-TB). ${ }^{11}$ A person is usually infected with drug-resistant TB by: (1) acquiring resistance by not taking the prescribed regimen appropriately or (2) being infected by an individual who is infected with a resistant strain of TB. ${ }^{109}$ Due to the problems with resistance and prolonged therapy, there is an urgent need to develop new, potent, fast acting anti-tuberculosis drugs with low toxicity.

\section{Targeting the Mycobacterium Cell Wall}

Introduction

One validated target for anti-mycobacterial agents is the cell wall, as many of the current drugs used to treat TB target the cell wall. ${ }^{124,125}$ All mycobacteria share a characteristic cell wall, thicker than in many other bacteria, which is hydrophobic, waxy, and rich in mycolic acids. ${ }^{42}$ The mycolic acids are important constituents of the mycobacterial cell wall in that they provide a permeability barrier at the cell's surface. 
The mycolic acids are fastened to the arabinogalactan layer which is subsequently tethered to the peptidoglycan layer (Figure 2.3). ${ }^{42}$ This complex cell wall structure of $M$. tuberculosis is believed to be associated with virulence, innate drug resistance, and persistence. ${ }^{126}$ The mycobacterial cell wall is unique to mycobacteria in that neither the cell wall nor the enzymes and chemical intermediates in its formation have analogues in humans making it an ideal target for drug development. ${ }^{127}$

\section{Rhamnose Biosynthesis}

In mycobacteria, L-rhamnose is essential to the structural integrity of the cell wall since it connects the peptidoglycan to the arabinogalactan layer. ${ }^{128,129}$ To date, neither rhamnose nor the genes responsible for its synthesis have been identified in humans making its biosynthesis a great target for drug design. ${ }^{128} \mathrm{~L}$ - rhamnose is incorporated in the bacterial polysaccharides from a common precursor, deoxythymidine diphosphate-Lrhamnose (dTDP-L-rhamnose). This precursor is synthesized from glucose-1-phosphate and deoxythymidine triphosphate (dTTP) via a pathway (Figure 2.5) that consists of four distinct enzymes: (1) Glucose-1-phosphate thymidyltransferase (RmlA), which couples the glucose-1-phosphate moiety to deoxythymidine triphosphate; (2) dTDP-D-glucose 4,6-dehydratase (RmlB), which oxidizes the 4' hydroxyl and dehydrates the 6' hydroxyl; (3) dTDP-6-deoxy-D-xylo-4-hexulose 3,5-epimerase ( $\mathrm{RmlC})$, which inverts the 3' and 5' hydroxyls; and (4) dTDP-6-deoxy-L-xylo-4-hexulose reductase (RmlD), which reduces the 4' ketone. ${ }^{128}$ Because it is structurally unique, highly substrate-specific, and does not require a cofactor, $\mathrm{RmlC}$ is considered to be the most promising drug target in the pathway. ${ }^{128,130,131}$ We chose RmlC as our target for drug design.

\section{Discovery of IC4760}

Several hit molecules were discovered by one of our collaborators, Dr. Michael McNeil at Colorado State University via high throughput screening of 35,000 compounds (Nanosyn, Tucson, AZ) for inhibitors of RmlB, RmlC, and RmlD simultaneously. ${ }^{127}$ Active compounds were ordered and re-assayed individually against the three enzymes. Many of the active compounds were grouped into three chemical motifs: rhodanines, pyrazolones, and quinoline carboxylics. Two of the most potent inhibitors from the assay contained the pyrazolone scaffold. Using one of the active pyrazolone compounds (Figure 2.5), a 2D similarity search was performed on the NCI depository to build a structre-activity relationship around this scaffold. In this screen IC4760 (Figure 2.6) was discovered as an inhibitor of RmlC (40\%@10 @ g/mL, MIC > $50 \mu \mathrm{g} / \mathrm{mL})$. This compound was less active than the first inhibitor, but had higher solubility and therefore was a better candidate for co-crystallograpy or crystal soaking experiments. Our other collaborator, Dr. James Naismith at the University of St. Andrew's, was able to obtain a co-crystal structure of IC4760 with RmlC giving very important structural insight allowing us to perform rounds of structure-based drug design. 


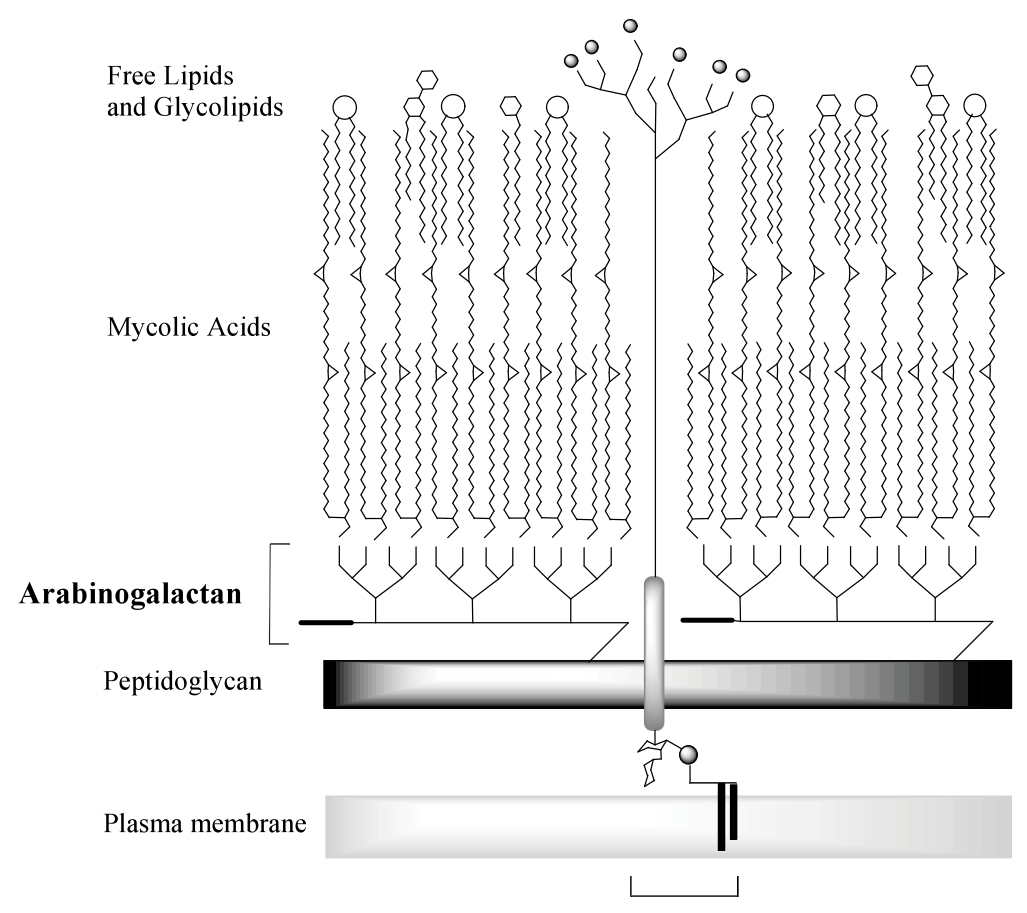

Lipoarabinomannan

Figure 2.3: Mycobacterial Cell Wall

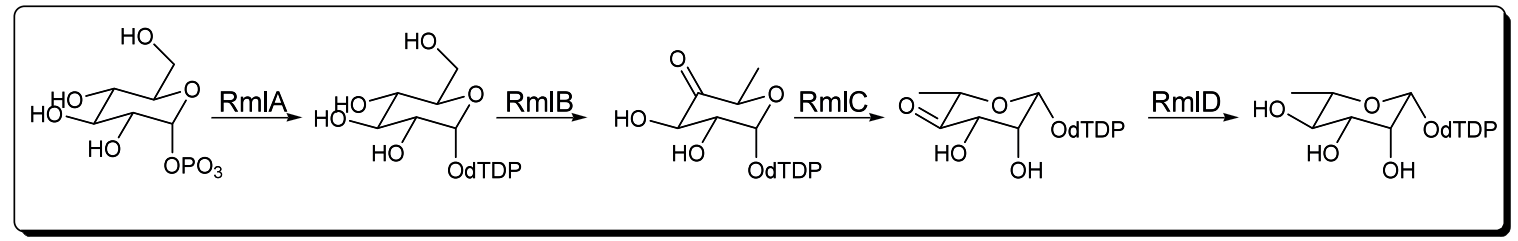

Figure 2.4: Rhamnose Biosynthetic Pathway

Permission to modify from: Giraud M.F. and Naismith J.H., The rhamnose pathway. Curr Opin Struc Biol 2000, 10, 687-96. ${ }^{128}$ 


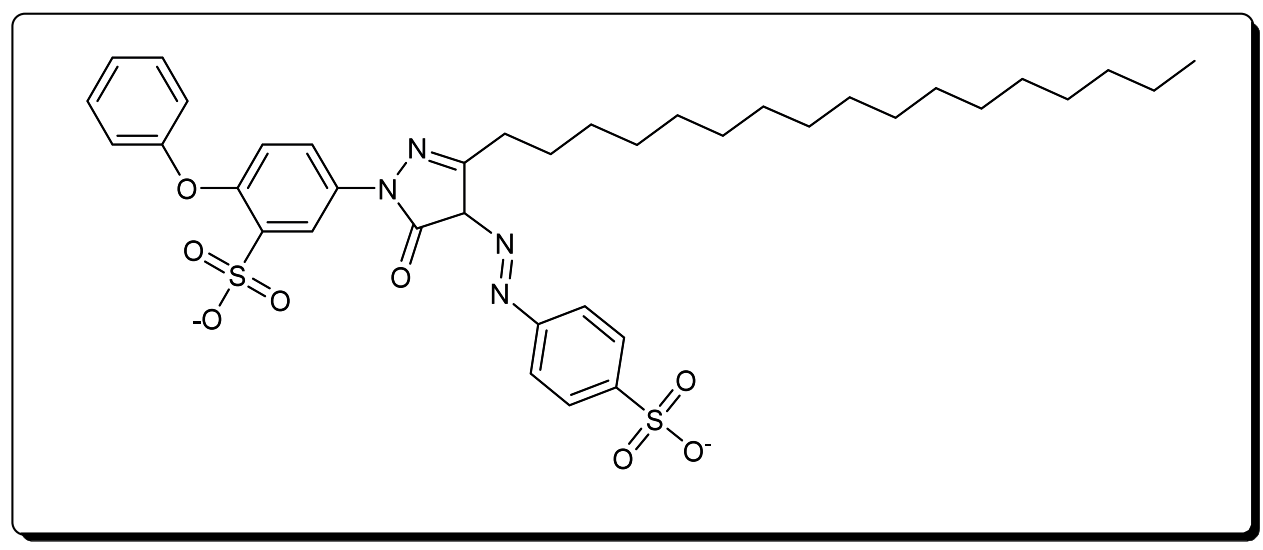

Figure 2.5: Original Pyrazalone Inhibitor 9861 from Screen

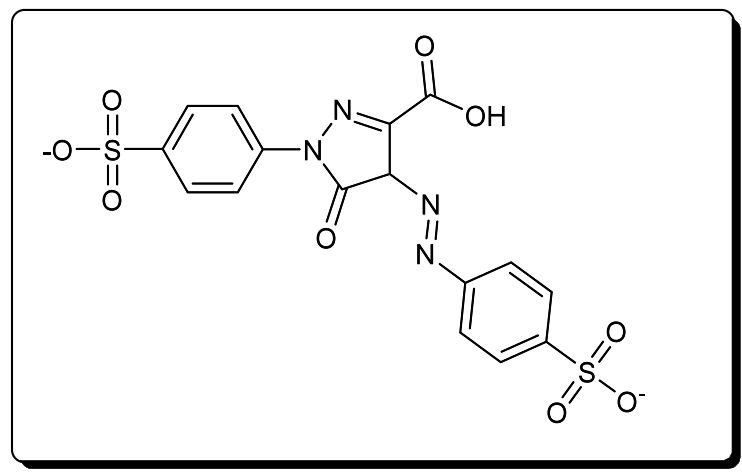

Figure 2.6: RmIC Inhibitor IC4760 
Generating a Pharmacophore Model

Two key co-crystal structures of enzyme-substrate and enzyme-IC4760 complexes were used to gain knowledge of the binding into the active site of the RmlC enzyme. The first co-crystal structure was of the product analog of RmlC, dTDPrhamnose, bound to the enzyme's active site (Figure 2.7). ${ }^{132}$ This structure provided insight to the positions of the sugar and nucleotide binding pockets. The thymidine ring was held in place between two aromatic side chains (Tyr and Phe) by $\pi$-stacking interactions. There was also a hydrogen bond interaction between one of the carbonyl oxygens of the thymine and the amino group of an asparagine residue. The rhamnose ring was bound deep in the pocket interacting with histidine and lysine residues that are thought to be important for the enzyme's function. ${ }^{130}$ The third important interaction involved the charge-charge interaction between the di-phosphate of dTDP-rhamnose and two arginine residues in the $\mathrm{RmlC}$ active site. The second co-crystal structure was of the inhibitor IC4760 bound to the enzyme's active site (Figure 2.8). ${ }^{132}$ This structure only included about two thirds of the molecule as the other parts could not be visualized within the electron density map. This structure confirmed that the inhibitor binds to the active site with the pyrazolone ring occupying the thymidine binding site and the sulfonate group interacting with the region that normally interacts with the phosphate group. These structures were very important in the development of the pharmacophore model. Figure $2.9^{132}$ shows the overlay of the two crystal structures: dTDP-rhamnose in green and inhibitor IC4760 in color. Three key structural features were important to the design of potential inhibitors: (1) an aromatic ring to bind to the nucleoside binding site; (2) a polar functional group that binds to the charged region made up of arginine residues; and (3) a cyclic or acyclic functional group that makes important amino interactions as seen with the rhamnose ring of the substrate. The use of these key structural features led us to the design, synthesis, and evaluation of bi-aryl sulfonamide libraries as potential inhibitors of Mycobacterium tuberculosis cell wall biosynthesis.

Virtual Screening Techniques in the Discovery of Novel RmlC Inhibitors

Previous work performed in our group involved the discovery of thiazolidinones as inhibitors of dTDP-rhamnose synthesis using a virtual screening approach. Kerim Babaoglu et al., described the synthesis of 4-thiazolidinones, a bioisosteric replacement for the diphosphate, as inhibitors of RmlC. ${ }^{133}$ These compounds were discovered by first generating a virtual library of compounds based on commercially available starting materials, then filtering them in silico by docking experiments to provide a more prioritized list of compounds for synthesis. From this study, several inhibitors of RmlC were discovered having $<50 \%$ inhibition @ 20 $\mu \mathrm{M}$ (Figure 2.10). None of the inhibitors showed significant whole cell antimicrobial activity (MIC $\geq 25 \mu \mathrm{g} / \mathrm{mL}$ ), however the study provided insight into the successful use of structure-guided library design as a tool for drug discovery. 


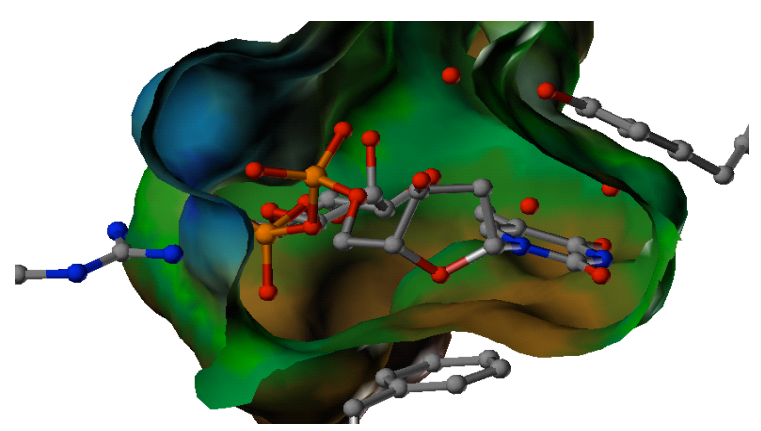

Figure 2.7: Crystal Structure of dTDP-Rhamnose in RmIC Active Site

Permission to modify from: Babaoglu, K., Use of modern structure-based drug design techniques in the discovery and development of novel antimicrobial candidates, Ph.D. dissertation, University of Tennessee Health Science Center, 2004. ${ }^{132}$

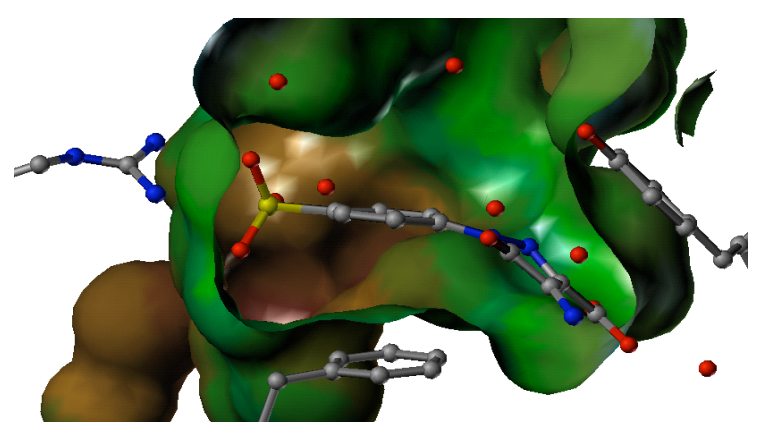

Figure 2.8: Crystal Structure of Inhibitor IC4760 in RmIC Active Site

Permission to modify from: Babaoglu, K., Use of modern structure-based drug design techniques in the discovery and development of novel antimicrobial candidates, Ph.D. dissertation, University of Tennessee Health Science Center, 2004. ${ }^{132}$ 


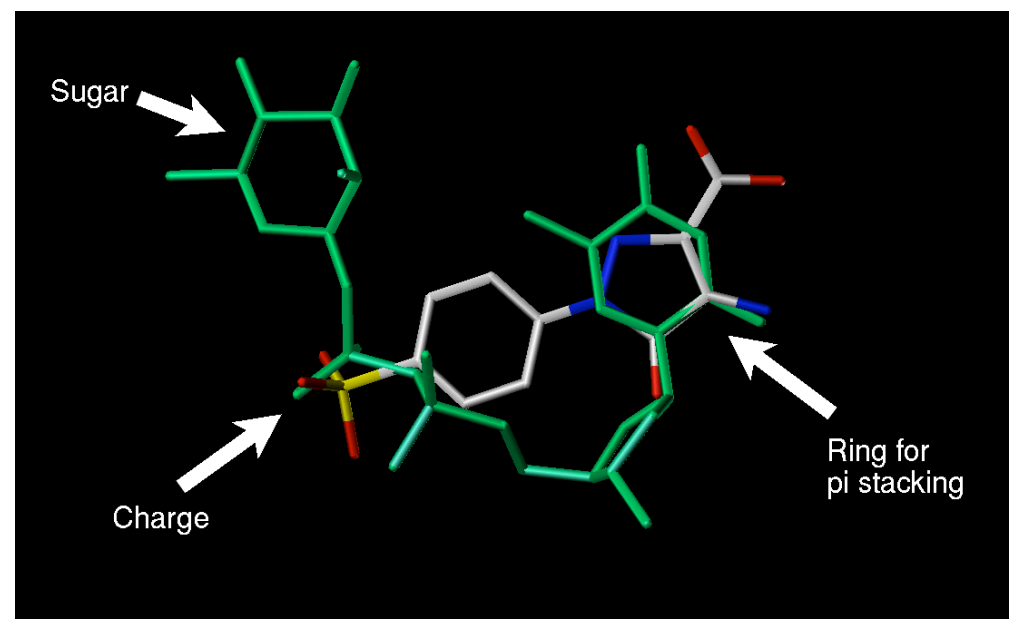

Figure 2.9: Pharmacophore Model

Permission to reprint from: Babaoglu, K., Use of modern structure-based drug design techniques in the discovery and development of novel antimicrobial candidates, Ph.D. dissertation, University of Tennessee Health Science Center, $2004 .{ }^{132}$

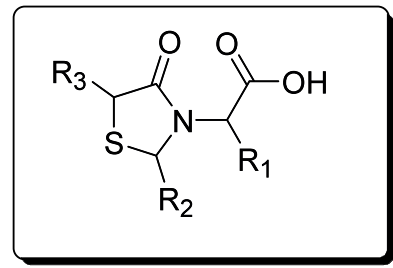

Figure 2.10: Thiazolidinone Scaffold for Inhibitors of RmIC 


\section{First Generation Sulfonamide Libraries}

Similar techniques were used in the discovery of potential sulfonamide inhibitors of RmlC as anti-tuberculosis agents. Based on the given pharmacophore model, bi-aryl sulfonamide libraries were designed (Figure 2.11). This library would include a heterocyclic ring mimicking the thymine ring, a sulfonamide moiety mimicking the phosphate group, and an amino side chain mimicking the rhamose sugar. A virtual library of 1274 sulfonamides was created in silico using Combilibmaker ${ }^{134}$, a module of the Tripos software package. One hundred and eighty two primary amines ${ }^{135}$ and 7 biaryl sulfonylchlorides ${ }^{136}$ from commercial vendors were visually inspected for the best pharmacophore match. These compounds were then docked into the $\mathrm{RmlC}$ active site using FlexX. ${ }^{137,138}$ Next, the compounds were ranked by consensus scoring $(\mathrm{CSCORE})^{134}$, and the top scoring compounds were visually examined to assure the pharmacophore pattern matched. Nineteen of top scoring compounds were selected for synthesis. Twelve of them were successfully synthesized and assayed.

\section{Synthesis}

Bi-aryl sulfonamides 2.3a-I were synthesized in parallel on a Radley's Carousel Synthesizer. Various bi-aryl sulfonyl chlorides 2.1 were reacted with corresponding primary amines 2.2 in DCM with catalytic amounts of polymer-supported dimethylamino pyridine (PS-DMAP) to afford the desired sulfonamides in low to moderate yields (Scheme 2.1).

\section{Results and Discussion}

The synthesized bi-aryl sulfonamides were tested for inhibition of the Mycobacterium tuberculosis RmlC (Table 2.1). Only two of the compounds tested showed inhibitory activity: 2.3c (25\%@100 $\mu \mathrm{M})$ and 2.3g (45\%@100 $\mathrm{MM})$. Both compounds had an aromatic ring that could make $\pi$-stacking interactions with the known pharmacophoric residues of the nucleoside binding pocket. The rings also contained hydrogen bond acceptor groups similar to that seen with the thymidine ring of dTDPrhamnose. The sulfonamide group is a bioisostere for the phosphate moiety that could make charge-charge interactions with active site arginine residues. Both compounds also contained a carboxylic acid moiety that could form hydrogen bond interactions with the lysine and histidine residues in the sugar pocket. The compounds were also tested for their antimicrobial activity against $M$. tuberculosis. Activity was generally weak with no compound having an MIC $<50 \mu \mathrm{g} / \mathrm{mL}$. The lack of anti-tuberuculosis activity is not suprising given the relative weak enzyme inhibition and potential poor penetration in the M. tuberculosis cell wall. In conclusion, inhibitors of M. tuberculosis $\mathrm{RmlC}$ were discovered. However, on the analysis of the starting materials, we believe there was a lack of suitable structural diversity of the commercially available bi-aryl sulfonyl chorides that match the pharmacophore thymidine moiety. With that, we moved to develop more complex bi-aryl sulfonamides to explore the nucleoside binding pocket. 


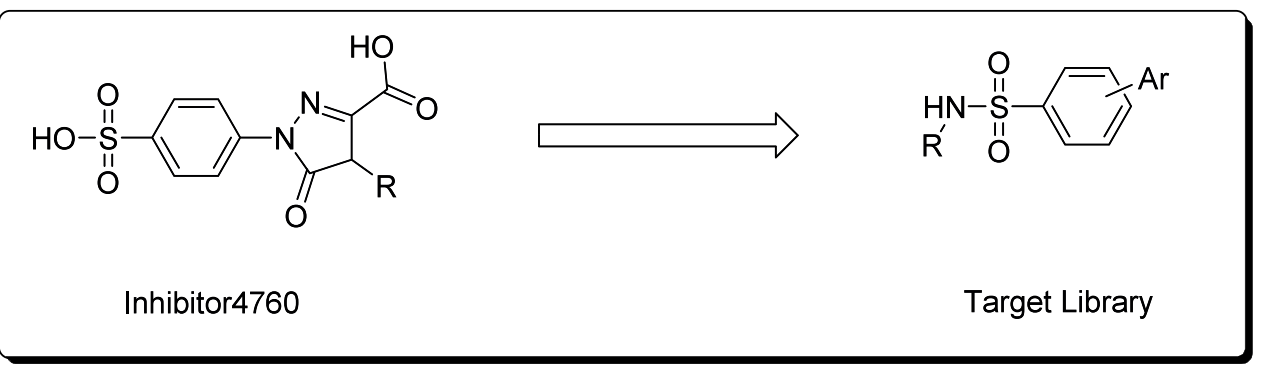

Figure 2.11: Target Sulfonamide Libarary

\section{Scheme 2.1: First Generation Sulfonamide Library}

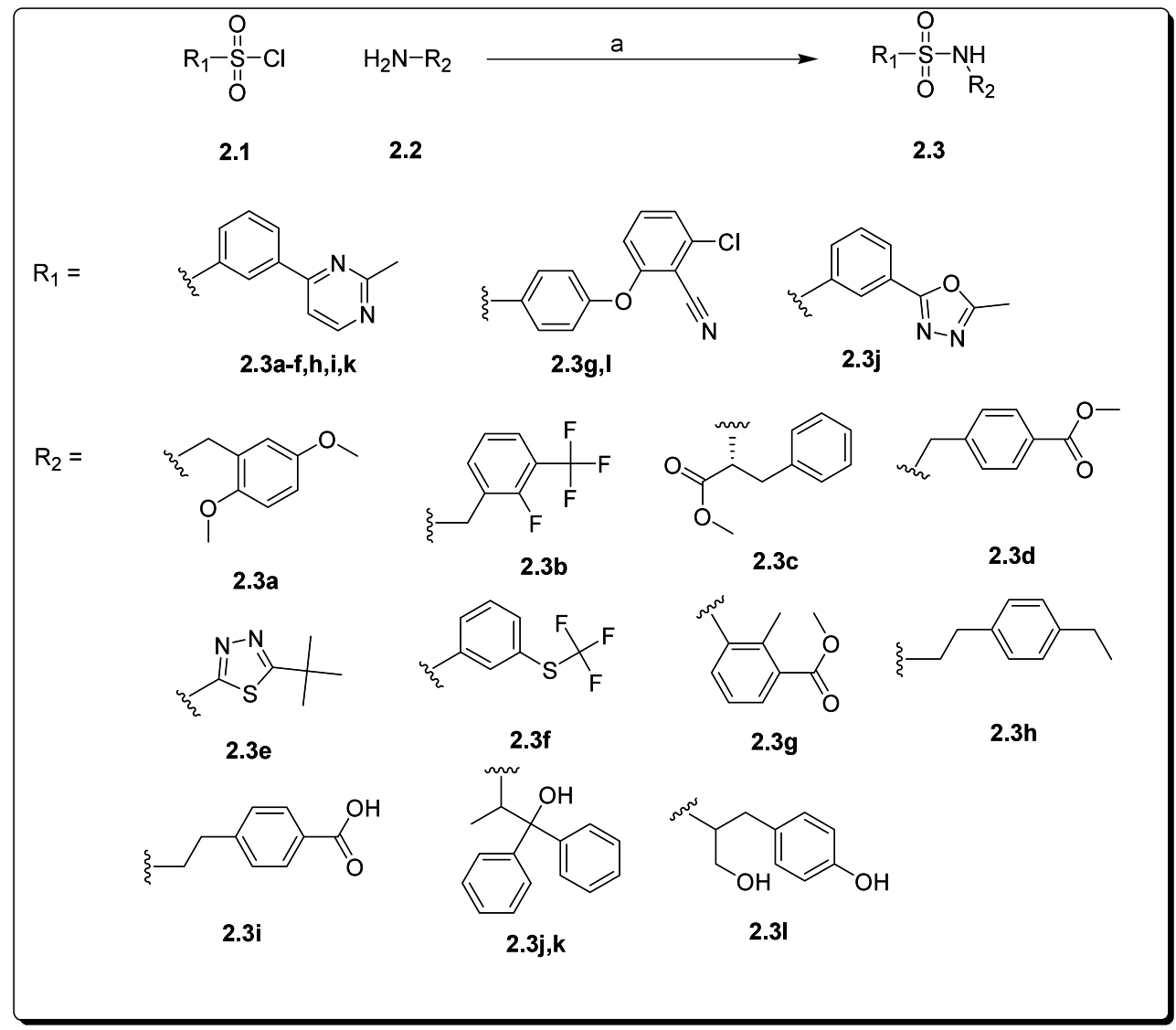

Reagents and Conditions: (a) PS-DMAP, DCM, rt, $16 \mathrm{~h}$. 
Table 2.1: Activity of First Generation Sulfonamide Library

\begin{tabular}{|c|c|c|}
\hline Compound & $\%$ Inhibition $^{\mathrm{a}}$ & $\operatorname{MIC}(\mu \mathrm{g} / \mathrm{mL})^{\mathrm{b}}$ \\
\hline $2.3 a$ & $\mathrm{na}^{\mathrm{c}}$ & 200 \\
\hline $2.3 b$ & na & 100 \\
\hline $2.3 \mathrm{c}$ & 25 & $>200$ \\
\hline $2.3 d$ & $n t^{d}$ & 200 \\
\hline $2.3 \mathrm{e}$ & $\mathrm{nt}$ & 200 \\
\hline $2.3 f$ & na & 50 \\
\hline $2.3 \mathrm{~g}$ & 45 & 100 \\
\hline $2.3 \mathrm{~h}$ & na & 50 \\
\hline $2.3 \mathrm{i}$ & na & $>200$ \\
\hline $2.3 \mathbf{j}$ & na & 200 \\
\hline $2.3 \mathrm{k}$ & na & 100 \\
\hline 2.31 & na & 100 \\
\hline
\end{tabular}

a \%Inhibition of M. tuberculosis RmlC @ 100 $\mu \mathrm{M}$ inhibitor. ${ }^{\mathrm{b}}$ Whole-cell Minimum Inhibitory Concentration of $M$. tuberculosis. ${ }^{\mathrm{c}}$ na $=$ no activity. ${ }^{\mathrm{d}} \mathrm{nt}=$ not tested. 


\section{Second Generation Bi-Aryl Sulfonamide Library}

In an attempt to address the low commercial availability of bi-aryl

sulfonylchlorides as thymidine mimics, as well as further explore the rhamnose sugar pocket, we synthesized a series of new bi-aryl sulfonamides using different chemistries. Using a retrosynthetic analysis approach (Figure 2.12), we decided to use palladiummediated Suzuki cross-coupling to group various aryl halides with heterocyclic boronic acids that were similar to the thymine moiety, to introduce more diversity. We also chose more primary amines that we considered would favor interactions seen with the rhamnose sugar moiety. The second generation bi-aryl sulfonamides were synthesized using high throughput synthesis.

\section{Palladium-Mediated Suzuki Cross Coupling}

Palladium-mediated Suzuki cross-coupling of aryl halides and aryl boronic acids is an extremely important method for the synthesis of biaryls. ${ }^{139-141}$ Many reagents are required for cross-coupling: palladium source, ligand, aryl/alkyl halide, boronic acid, base, and heat. Boronic acids are generally non-toxic and thermally, air, and moisture stable which gives it the advantage over other cross-coupling processes. ${ }^{140}$ There are many protocols for Suzuki cross-coupling in the literature of which the choice depends on the structure of the reactants. As previously mentioned, polymer-supported reagents for solution phase synthesis has become an increasingly utilized tool for the preparation of molecules. ${ }^{139,142}$ The number one reason for their use is the ease of purification by filtration. These reagents are attractive since excess amounts can be used to enhance chemoselectivity and drive reactions to completion. ${ }^{143}$ Polymer-supported palladium catalysts have been introduced as opposed to using a soluble catalyst because they offer significant benefits: (1) they can be easily removed at the end of the reaction by filtration; (2) the products obtained typically contain much lower levels of residual phosphine oxide and palladium which can be extremely toxic as opposed to the soluble catalysts; and (3) they are air-stable and can be handled under ambient conditions. ${ }^{139,142 \text {, }}$ 143

Microwave Assisted Organic Synthesis

Microwave chemistry has been around since mid-1980's, in which domestic microwaves were used, which has been proven to be unsafe. ${ }^{144}$ However, development of efficient new technology has allowed microwave chemistry to gain more acceptance and popularity. The use of microwaves for carrying out reactions in the laboratory provides advantages for synthesis: (1) reduces reaction times; (2) gives cleaner reaction due to fewer side reactions; and (3) requires only minimal quantities of solvent. ${ }^{145,146}$ Virtually all thermally driven reactions can be accelerated by microwave heating. ${ }^{144}$ Microwaves increase reaction rates by providing the momentum to overcome the transition state barrier and complete the reaction more quickly than conventional heating. ${ }^{144}$ Unlike conventional heating, microwave heating is uniform. Suzuki coupling 


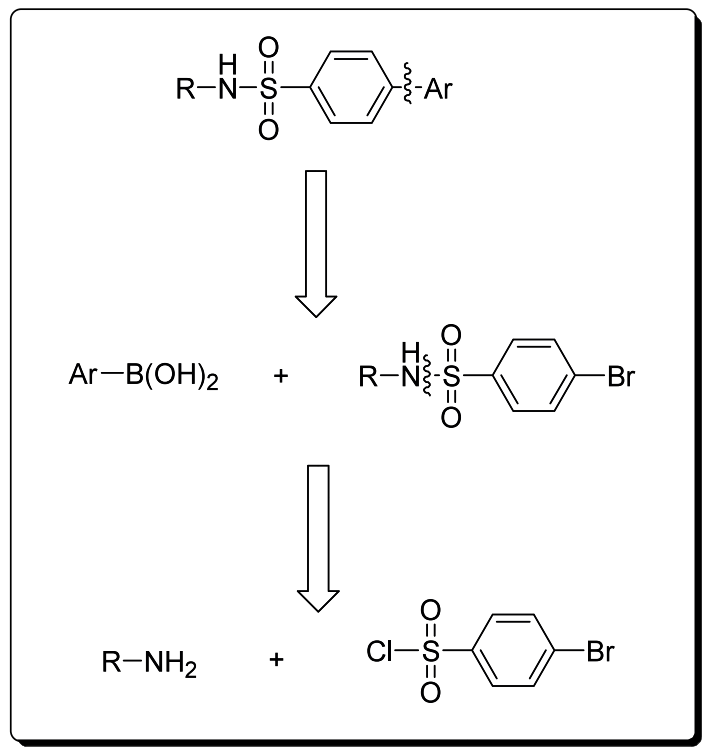

Figure 2.12: Retrosynthetic Analysis for Second Generation Sulfonamide Library 
using conventional heating methods is often sluggish and, in some cases, can take a number of days to go to completion. This limitation can be overcome using microwave heating, enabling reaction times to be reduced to just a few minutes. ${ }^{139,147}$

\section{Method Development}

Four methods were evaluated to prepare for the parallel synthesis of the target biaryl sulfonamide library (Table 2.2). The four methods evaluated the use of a polymersupported catalyst versus its soluble counterpart, as well as, the use of microwave technology versus convential heating methods.

\section{Synthesis}

Three bi-aryl sulfonamides $\mathbf{2 . 8 a a}, \mathbf{a b}, \mathbf{b a}$ were synthesized for chemistry optimization. The starting materials were chosen to cover the diversity of compounds that would be used for library synthesis. The bromoaryl sulfonamide intermediates 2.6a,b were synthesized by reacting 4-bromobenzene sulfonylchloride 2.5 with primary amines 2.4a,b in DCM and diisopropylethylamine (DIPEA) for 16h (Scheme 2.2). After purification, the sulfonamide intermediates $\mathbf{2 . 6 a}, \mathbf{b}$ were coupled with aryl boronic acids 2.7a,b using four methods as outlined in Table 2.2. After the reaction was complete, the mixtures were filtered and concentrated. The crude mixtures were then tested for purity via RP-HPLC (Table 2.3).

\section{Results and Discussion}

From the four methods used, all compounds showed purity $>73 \%$ with most being above $90 \%$. Based on the purity results, there wasn't much difference in the use of the soluble catalyst versus the polymer-supported catalyst. However, the polymer-supported catalyst had advantages in that (1) it was easier to weigh out; (2) the nature of the catalyst allowed it to be handled in an air atmosphere; and (3) the work-up of the reaction is easier by just filtration of the polymer support. In the use of microwave technology over conventional heating methods, generally the microwave produced compounds with higher purity ranges (mostly $>90 \%$ verus $83-92 \%$ with conventional methods). The microwave had significant advantages over conventional heating methods in that: (1) reaction times were decreased from $16 \mathrm{~h}$ to $10 \mathrm{~min}$; (2) less space for the heating apparatuses were used; and (3) temperatures could be exceeded far beyond that of the oil bath for sluggish reactions. In conclusion, four methods were performed to synthesize more complex bi-aryl sulfonamides which produced compounds with purity ranging from 73-96\%. Method III, using soluble $\mathrm{Pd}\left(\mathrm{PPh}_{3}\right)_{4}$ in the microwave, proved to be the best method for synthesizing our complex bi-aryl sulfonamides with purity ranging from 90$96 \%$. Though Method III produced the best results, Method IV was easier and quicker providing a more efficient method that required less post synthesis purification for parallel synthesis. Therefore, Method IV, using PS-Pd( $\left(\mathrm{Ph}_{3}\right)_{4}$ and microwave technology, was the chosen method for synthesis of the target bi-aryl sulfonamide library. 
Table 2.2: Reaction Conditions for Chemistry Optimization

\begin{tabular}{ccc}
\hline Method & Catalyst & $\begin{array}{c}\text { Reaction } \\
\text { Conditions }\end{array}$ \\
\hline I & $\mathrm{Pd}\left(\mathrm{PPh}_{3}\right)_{4}$ & $\begin{array}{c}\text { Oil bath, } 80^{\circ} \mathrm{C}, \\
16 \mathrm{~h}\end{array}$ \\
II & $\mathrm{PS}^{-}$ & Oil bath, $80^{\circ} \mathrm{C}$, \\
& $\mathrm{Pd}^{\left(\mathrm{PPh}_{3}\right)_{4}}$ & $16 \mathrm{~h}$ \\
III & $\mathrm{Pd}\left(\mathrm{PPh}_{3}\right)_{4}$ & Microwave, \\
& & $160^{\circ} \mathrm{C}, 10 \mathrm{~min}$ \\
IV & $\mathrm{PS}^{-}$ & Microwave, \\
& $\mathrm{Pd}\left(\mathrm{PPh}_{3}\right)_{4}$ & $160^{\circ} \mathrm{C}, 10 \mathrm{~min}$ \\
\hline
\end{tabular}

\section{Scheme 2.2: Compounds for Chemistry Optimization}

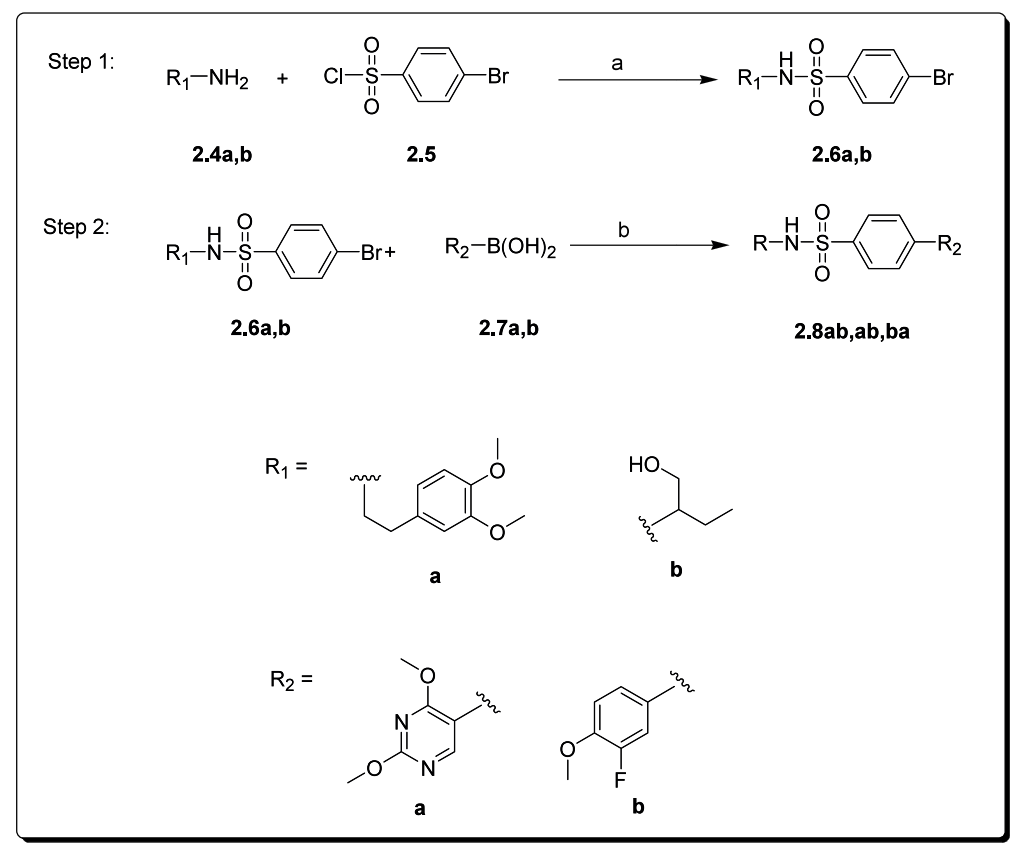

Reagents and Conditions: (a) DIPEA, DCM, rt, 16h; (b) $\mathrm{Na}_{2} \mathrm{CO}_{3}$, DME:EtOH: $\mathrm{H}_{2} \mathrm{O}$, Methods I-IV (Table 2.2). 
Table 2.3: \% Purity of Compounds for Method Development

\begin{tabular}{|c|c|c|c|c|}
\hline Compound & Method I & Method II & Method III & Method IV \\
\hline 2.8aa & 88 & 83 & 94 & 94 \\
\hline 2.8ab & 93 & 89 & 90 & 73 \\
\hline $2.8 \mathrm{ba}$ & 83 & 92 & 96 & 95 \\
\hline
\end{tabular}


Synthesis

Bromoaryl sulfonamide intermediates 2.6a-k were synthesized in parallel on a Radley's Carousel Synthesizer. 4-bromobenzene sulfonylchloride $\mathbf{2 . 5}$ was reacted with respective primary amines $\mathbf{2 . 4 a - k}$ in DCM and diisopropylethylamine (DIPEA) for $16 \mathrm{~h}$ to afford the desired sulfonamide intermediates in good yields (Scheme 2.3). After purification, the sulfonamide intermediates $\mathbf{2 . 6 a - k}$ were reacted with various aryl boronic acids 2.7a-i in the presence of sodium carbonate, polymer-supported tetrakis triphenylphosphine palladium (PS- $\left.\mathrm{Pd}\left(\mathrm{Ph}_{3}\right)_{4}\right)$ and a mixture of dimethoxyethane, ethanol, and water (DME:EtOH: $\mathrm{H}_{2} \mathrm{O}$ ) (Scheme 2.4). ${ }^{139,142}$ The reaction was performed under argon and allowed to react under the following microwave conditions: $100 \mathrm{~W}, 150^{\circ} \mathrm{C}$, $100 \mathrm{psi}, 10 \mathrm{~min}$. The mixtures were filtered and purified via RP-HPLC to afford the desired bi-aryl sulfonamides $\mathbf{2 . 8}$ in moderate yields.

Results and Discussion

The synthesized second generation bi-aryl sulfonamides were tested for inhibition of the $M$. tuberculosis RmlC (Table 2.4). Compounds 2.8fe $(23 \% @ 50 \mu \mathrm{M}), \mathbf{2 . 8 g b}(27 \%$ ( ) $50 \mu \mathrm{M})$ and 2.8jg $(28 \% @ 50 \mu \mathrm{M})$ proved to be the most active in the library. To gain information on the binding mode of these inhibitors, docking experiments were performed. Using $\mathbf{2 . 8 j g}$ as a representative, the inhibitor $\mathbf{2 . 8 j g}$ binds similar to the substrate analog dTDP-rhamnose. A view of the best docking solution for inhibitor $\mathbf{2 . 8 j g}$ is superimposed on dTDP-rhamnose (green) in the active site of RmlC (Figure 2.13). In the nucleoside binding pocket, the aromatic ring of the inhibitor does not align for $\pi$ stacking as seen with the inhibitor 4760, however, it does undergo hydrogen bonding with the asparagine residue. The sulfonamide portion of the inhibitor binds to the charged pocket as seen with the di-phosphate moiety of dTDP-rhamnose and the sulfonate group of the inhibitor 4760. Also, the amino group resides in the sugar binding pocket to undergo hydrogen bonding with the His residues. In conclusion, a new bi-aryl sulfonamide inhibitor of $\mathrm{RmlC}$ with weak whole-cell activity was discovered. We sought to explore more diversity of the nucleoside and sugar pockets in which we were successful. However, we did not fully explore the diversity as selection of the starting materials was limited. At the time during library development, the amines chosen were based on those that were available in the laboratory; the boronic acids chosen were based on visual inspection of a pharmacophoric match; and based on the ease of synthesis, only one sulfonyl chloride was chosen, which was based on the IC4760 scaffold for which our libraries were shaped. We further planned to expand diversity in the thymidine binding pocket and the sugar pocket using a structure guided library approach to maximize interactions in the active site and potentially yield more desirable leads. 
Scheme 2.3: Synthesis of Sulfonamide Intermediates

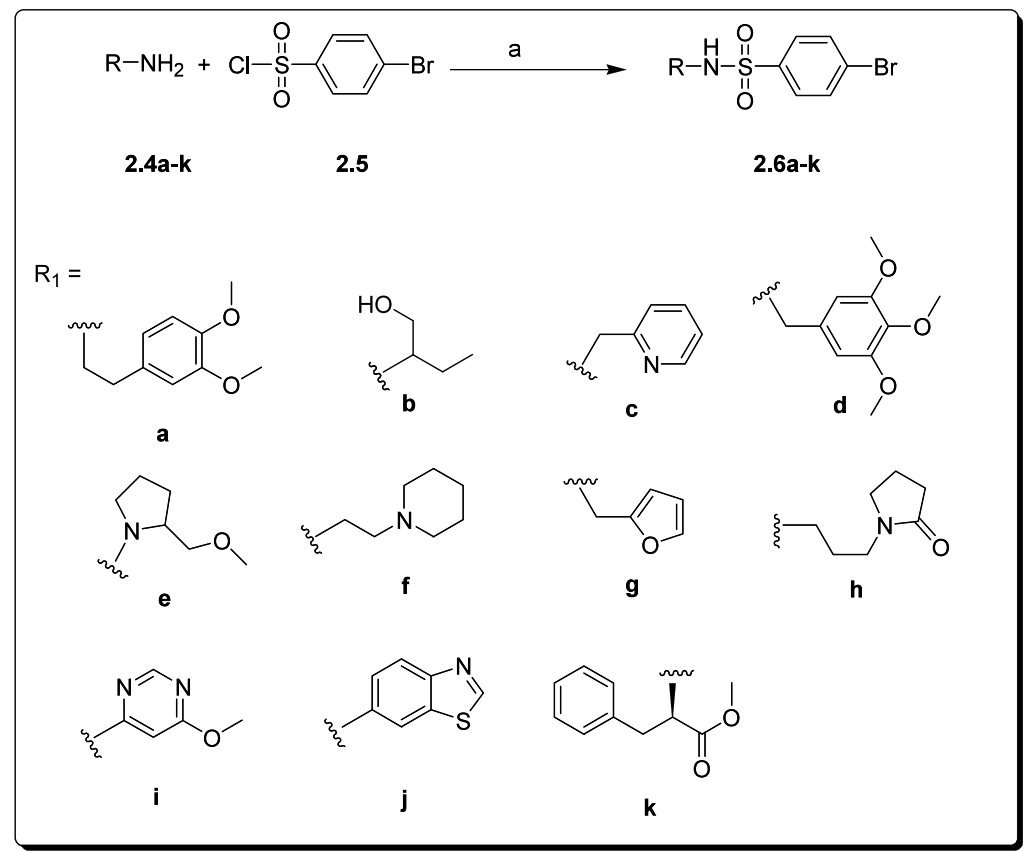

Reagents and Conditions: (a) DIPEA, DCM, rt, 16h. 


\section{Scheme 2.4: Synthesis of Bi-Aryl Sulfonamides via Suzuki Coupling}

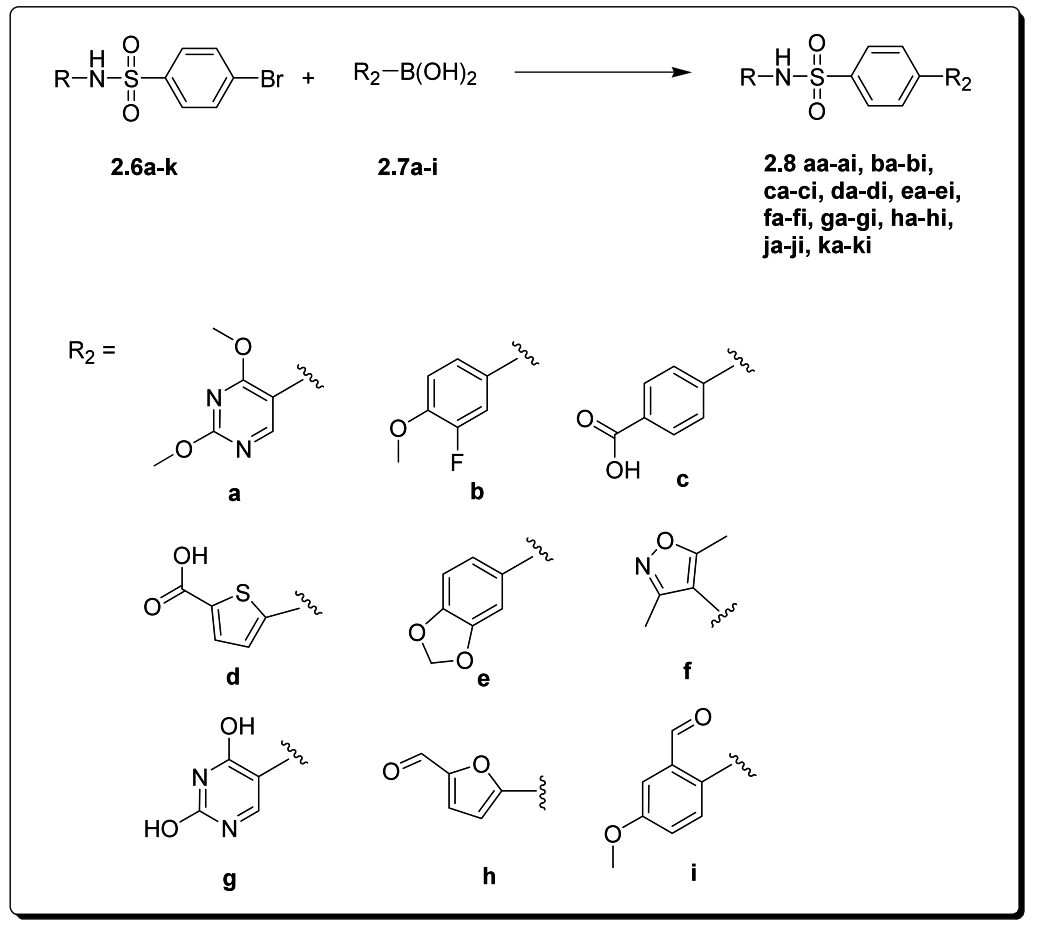

Reagents and Conditions: (a) PS-Pd( $\left(\mathrm{PPh}_{3}\right)_{4}, \mathrm{Na}_{2} \mathrm{CO}_{3}, \mathrm{DME} / \mathrm{H}_{2} \mathrm{O} / \mathrm{EtOH}, \mathrm{MW}, 160^{\circ} \mathrm{C}, 10$ min, 100 psi. 
Table 2.4: Activity of Second Generation Bi-Aryl Sulfonamide Library

\begin{tabular}{|c|c|c|c|}
\hline \multicolumn{2}{|r|}{ Compound } & $\%$ Inhibition $^{\mathrm{a}}$ & $\operatorname{MIC}(\mu \mathrm{g} / \mathrm{mL})^{\mathrm{b}}$ \\
\hline 2.8ab & & 7 & 100 \\
\hline $2.8 \mathrm{ac}$ & & 8 & 100 \\
\hline $2.8 \mathrm{ae}$ & & 4 & 100 \\
\hline 2.8ag & & 14 & 50 \\
\hline 2.8ai & & 16 & 50 \\
\hline $2.8 \mathrm{bb}$ & & 14 & $25^{\mathrm{c}}$ \\
\hline $2.8 \mathrm{cb}$ & & 4 & $25^{\mathrm{c}}$ \\
\hline $2.8 \mathrm{eg}$ & & 18 & 100 \\
\hline $2.8 \mathrm{fe}$ & & 23 & 100 \\
\hline $2.8 \mathrm{gb}$ & & 27 & $25^{\mathrm{c}}$ \\
\hline $2.8 \mathrm{ge}$ & & 19 & $25^{\mathrm{c}}$ \\
\hline $2.8 \mathrm{gi}$ & & 0 & $50^{c}$ \\
\hline $2.8 \mathrm{hb}$ & & 0 & $200^{c}$ \\
\hline 2.8he & & 13 & $100^{\mathrm{c}}$ \\
\hline
\end{tabular}


Table 2.4: Continued

\begin{tabular}{|c|c|c|c|}
\hline \multicolumn{2}{|r|}{ Compound } & $\%$ Inhibition $^{\mathrm{a}}$ & $\operatorname{MIC}(\mu \mathrm{g} / \mathrm{mL})^{\mathrm{b}}$ \\
\hline 2.8ib & & 0 & $100^{\mathrm{c}}$ \\
\hline 2.8ie & & 3 & $100^{\mathrm{c}}$ \\
\hline $2.8 \mathrm{ii}$ & & 0 & $100^{\mathrm{c}}$ \\
\hline $2.8 j f$ & & 18 & 100 \\
\hline $2.8 \mathrm{jg}$ & & 29 & 50 \\
\hline $2.8 \mathrm{ji}$ & & 9 & 100 \\
\hline
\end{tabular}

a \%Inhibition of M. tuberculosis RmlC@50 $\mu \mathrm{M}$ inhibitor. ${ }^{\mathrm{b}}$ Whole-cell Minimum Inhibitory Concentration of M. tuberculosis ${ }^{c}$ Showed obscure growth to bacteria. 


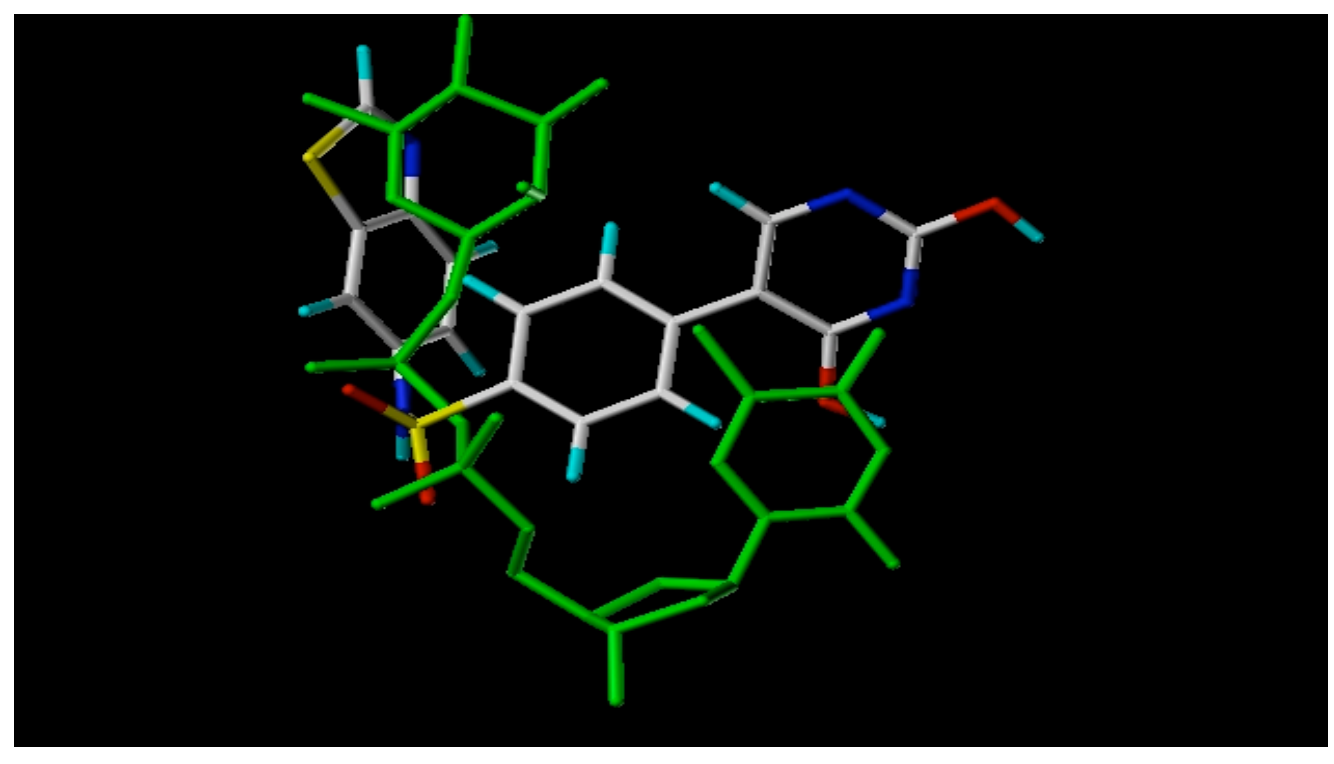

Figure 2.13: Docking Solution of 2.8jg 


\section{Overall Conclusions}

In the development of anti-tuberculosis drugs, bi-aryl sulfonamides have been successfully synthesized as potential inhibitors of rhamnose biosynthesis using a structure guided library approach. From this study, several inhibitors of Mycobacterium tuberculosis $\mathrm{RmlC}$ were discovered with compounds $\mathbf{2 . 3 c}, \mathbf{2 . 3 g}$, and $\mathbf{2 . 8 j g}$ showing promise as leads for future library development. These compounds showed favorable interactions as seen by our hit compound for which our libraries have been designed. Future work involves obtaining co-crystal structures of these compounds with RmlC which will help shape the design and synthesis of future libraries.

\section{Experimental Section}

Chemistry

All reagents and anhydrous solvents were purchased from Sigma-Aldrich. All the reagent-grade solvents used for chromatography were purchased from Fisher Scientific (Suwanee, GA) and flash column chromatography silica cartridges were obtained from Biotage Inc. (Lake Forest, VA). A Biotage FLASH column chromatography system was used to purify some of the reaction mixtures. Other compounds were purified via preparative RP-HPLC on a Gibson HPLC system. RP-HPLC 1 methods were conducted using a Phenomenex Luna $5 \mu \mathrm{C}-18$ column $(150 \times 21.2 \mathrm{~mm})$ at ambient temperature, and a flow rate of $4.0 \mathrm{~mL} / \mathrm{min}$. HPLC1: Gradient: solvent A $(0.1 \%$ TFA in water $)$ and solvent B (acetonitrile): 0-2.00 min 20\% B, 2.00-17.00 min 20-100\% B (linear gradient), 17.00-19.00 $\min 100 \% \mathrm{~B}, \mathrm{UV}$ detection at $254 \mathrm{~nm}$. All $1 \mathrm{H}$ spectra were recorded on a Varian INOVA-500 spectrometer. Chemical shifts ( $\delta)$ are reported in ppm relative to the residual solvent peak or internal standard (tetramethylsilane), and coupling constants $(J)$ are reported in hertz $(\mathrm{Hz})$. Mass spectra were recorded on a Bruker Esquire LCMS using ESI. The yields quoted are unoptimized. The purity of the final compounds was tested via preparative RP-HPLC on a Hewlet Packet (HP1100series) HPLC system. RP-HPLC 2 methods were conducted using an Alltech Platinum EPS $5 \mu \mathrm{C}-18$ column $(150 \times 4.6$ $\mathrm{mm}$ ) at ambient temperature, and a flow rate of $1.0 \mathrm{~mL} / \mathrm{min}$. HPLC2: Gradient: solvent $\mathrm{A}(0.1 \%$ TFA in water) and solvent B (acetonitrile): 0-2.00 min 0\% $\mathrm{B}, 2.00-17.00 \mathrm{~min} 0$ 100\%B (linear gradient), 17.00-19.00 100\%B, UV detection at 254nm.

General procedure for the synthesis of first generation biaryl sulfonamides (2.3a-l). To a carousel tube, $3 \mathrm{ml}$ of pyridine was added. Next, PS-DMAP (1.4 eq, $0.7 \mathrm{mmol}$ ) was added to each tube. Various sulfonylchlorides (1.0 eq, $0.5 \mathrm{mmol})$ were added followed by respective amines ( $1.0 \mathrm{eq}, 0.5 \mathrm{mmol})$ to the tube. The mixture was allowed to stir at room temperature overnight. The mixture was filtered and washed with chloroform. The filtrate and washings were combined and concentrated in vacuo. Flash column purification (0-100\%) Petroleum Ether/Ethyl Acetate) yielded the corresponding sulfonamides. 
$N$-(2,5-dimethoxy-benzyl)-3-(2-methyl-pyrimidin-4-yl)-benzenesulfonamide (2.3a). Using the above procedure, 3-(2-methyl-pyrimidin-4-yl)-benzenesulfonyl chloride (0.5 mmol), 2,5-dimethoxy-benzylamine $(0.5 \mathrm{mmol})$, PS-DMAP $(0.7 \mathrm{mmol})$, and pyridine (3 $\mathrm{mL}$ ) were used to synthesize $\mathbf{2 . 3 a}$ as a light yellow solid $(21 \%)$. ${ }^{1} \mathrm{HNMR}(500 \mathrm{MHz}$, $\left.\mathrm{CDCl}_{3}\right): \delta 2.89(\mathrm{~s}, 3 \mathrm{H}), 3.64(\mathrm{~s}, 3 \mathrm{H}), 3.69(\mathrm{~s}, 3 \mathrm{H}), 4.24(\mathrm{~d}, 2 \mathrm{H}, J=6.5 \mathrm{~Hz}), 5.58(\mathrm{t}, 1 \mathrm{H}, J$ $=6.0 \mathrm{~Hz}), 6.57(\mathrm{~m}, 2 \mathrm{H}), 6.65(\mathrm{~s}, 1 \mathrm{H}), 7.51(\mathrm{~d}, 1 \mathrm{H}, J=5.5 \mathrm{~Hz}), 7.56(\mathrm{t}, 1 \mathrm{H}, J=8.0 \mathrm{~Hz})$, $7.92(\mathrm{~d}, 1 \mathrm{H}, J=8.0 \mathrm{~Hz}), 8.45(\mathrm{~s}, 1 \mathrm{H}), 8.75(\mathrm{~d}, 1 \mathrm{H}, J=5.0 \mathrm{~Hz}) . \operatorname{MS}(\mathrm{ESI}): \mathrm{m} / \mathrm{z}=422.3$ $(\mathrm{M}+\mathrm{Na})^{+}$. HPLC2: $t_{\mathrm{R}} 3.0$ min, Purity $90 \%$.

\section{$\mathrm{N}$-(2-fluoro-3-trifluoromethyl-benzyl)-3-(2-methyl-pyrimidin-4-yl)-}

benzenesulfonamide (2.3b). Using the above procedure, 3-(2-methyl-pyrimidin-4-yl)benzenesulfonyl chloride $(0.5 \mathrm{mmol}), 2$-fluoro-3-trifluoromethyl-benzylamine $(0.5$ mmol), PS-DMAP $(0.7 \mathrm{mmol})$, and pyridine $(3 \mathrm{~mL})$ were used to synthesize $\mathbf{2 . 3 b}$ as a light yellow solid $(3 \%)$. ${ }^{1} \mathrm{HNMR}\left(500 \mathrm{MHz}, \mathrm{CDCl}_{3}\right): \delta 2.74(\mathrm{~s}, 3 \mathrm{H}), 4.27(\mathrm{~d}, 2 \mathrm{H}, J=5.5$ $\mathrm{Hz}), 5.07$ (t, 1H, $J=6.0 \mathrm{~Hz}), 7.05(\mathrm{t}, 1 \mathrm{H}, J=8.0 \mathrm{~Hz}), 7.36(\mathrm{t}, 1 \mathrm{H}, J=7.0 \mathrm{~Hz}), 7.43$ (d, $1 \mathrm{H}, J=5.5 \mathrm{~Hz}), 7.47(\mathrm{t}, 1 \mathrm{H}, J=7.5 \mathrm{~Hz}) 7.53(\mathrm{t}, 1 \mathrm{H}, J=8.0 \mathrm{~Hz}), 7.85(\mathrm{~d}, 1 \mathrm{H}, J=8.0 \mathrm{~Hz})$ $8.18(\mathrm{~d}, 1 \mathrm{H}, J=7.5 \mathrm{~Hz}), 8.43(\mathrm{~s}, 1 \mathrm{H}), 8.66(\mathrm{~d}, 1 \mathrm{H}, J=5.5 \mathrm{~Hz}) . \operatorname{MS}(\mathrm{ESI}): \mathrm{m} / \mathrm{z}=448.3$ $(\mathrm{M}+\mathrm{Na})^{+}$. HPLC2: $t_{\mathrm{R}} 5.1$ min, Purity $>99 \%$.

\section{2-[3-(2-methyl-pyrimidin-4-yl)-benzenesulfonylamino]-3-phenyl-propionic acid} methyl ester (2.3c). Using the above procedure, 3-(2-methyl-pyrimidin-4-yl)benzenesulfonyl chloride (0.5 mmol), 2-amino-3-phenyl-propionic acid methyl ester (0.5 mmol), PS-DMAP $(0.7 \mathrm{mmol})$, and pyridine $(3 \mathrm{~mL})$ were used to synthesize $\mathbf{2 . 3 c}$ as a light yellow solid $(33 \%)$. ${ }^{1} \mathrm{HNMR}\left(500 \mathrm{MHz}, \mathrm{CDCl}_{3}\right): \delta 2.82(\mathrm{~s}, 3 \mathrm{H}), 3.06(\mathrm{dd}, 2 \mathrm{H}, J=$ $6.0,6.5 \mathrm{~Hz}), 3.50(\mathrm{~s}, 3 \mathrm{H}), 4.30(\mathrm{~m}, 1 \mathrm{H}), 4.43(\mathrm{t}, 1 \mathrm{H}, J=6.0 \mathrm{~Hz}), 7.08(\mathrm{~d}, 2 \mathrm{H}, J=7.0 \mathrm{~Hz})$, $7.20(\mathrm{~m}, 3 \mathrm{H}), 7.53(\mathrm{~d}, 1 \mathrm{H}, J=5.5 \mathrm{~Hz}) 7.59(\mathrm{t}, 1 \mathrm{H}, J=8.0 \mathrm{~Hz}), 7.86(\mathrm{~d}, 1 \mathrm{H}, J=8.0 \mathrm{~Hz})$, $8.31(\mathrm{~d}, 1 \mathrm{H}, J=7.5 \mathrm{~Hz}), 8.46(\mathrm{~s}, 1 \mathrm{H}), 8.73(\mathrm{~d}, 1 \mathrm{H}, J=5.0 \mathrm{~Hz}) . \operatorname{MS}(\mathrm{ESI}): \mathrm{m} / \mathrm{z}=434.2$ $(\mathrm{M}+\mathrm{Na})^{+}$. HPLC2: $t_{\mathrm{R}} 3.3$ min, Purity $88 \%$.

4-\{[3-(2-methyl-pyrimidin-4-yl)-benzenesulfonylamino]-methyl $\}$-benzoic acid methyl ester (2.3d). Using the above procedure, 3-(2-methyl-pyrimidin-4-yl)benzenesulfonyl chloride (0.5 mmol), 4-aminomethyl-benzoic acid methyl ester (0.5 mmol), PS-DMAP $(0.7 \mathrm{mmol})$, and pyridine $(3 \mathrm{~mL})$ were used to synthesize $2.3 \mathrm{~d}$ as a light yellow solid (3\%). ${ }^{1} \mathrm{HNMR}\left(500 \mathrm{MHz}, \mathrm{CDCl}_{3}\right): \delta 2.94(\mathrm{~s}, 3 \mathrm{H}), 3.94(\mathrm{~s}, 3 \mathrm{H}), 4.34$ $(\mathrm{d}, 2 \mathrm{H}, J=5.5 \mathrm{~Hz}), 5.11(\mathrm{t}, 1 \mathrm{H}, J=6.0 \mathrm{~Hz}), 7.33(\mathrm{~d}, 2 \mathrm{H}, J=8.5 \mathrm{~Hz}), 7.70(\mathrm{~d}, 2 \mathrm{H}, J=8.0$ Hz) $7.92(\mathrm{~d}, 2 \mathrm{H}, J=8.0 \mathrm{~Hz}), 8.04(\mathrm{~d}, 1 \mathrm{H}, J=7.5 \mathrm{~Hz}) 8.35(\mathrm{~d}, 1 \mathrm{H}, J=7.5 \mathrm{~Hz}), 8.57$ (s, 1H), $8.87(\mathrm{bs}, 1 \mathrm{H})$. MS(ESI): $\mathrm{m} / \mathrm{z}=398.3(\mathrm{M}+\mathrm{H})^{+}$. HPLC2: $t_{\mathrm{R}} 3.2 \mathrm{~min}$, Purity $>99 \%$.

\section{$N$-(5-tert-Butyl-[1,3,4]thiadiazol-2-yl)-3-(2-methyl-pyrimidin-4-yl)-}

benzenesulfonamide (2.3e). Using the above procedure, 3-(2-methyl-pyrimidin-4-yl)benzenesulfonyl chloride $(0.5 \mathrm{mmol}), 5$-tert-butyl-[1,3,4]thiadiazol-2-ylamine $(0.5$ mmol), PS-DMAP $(0.7 \mathrm{mmol})$, and pyridine $(3 \mathrm{~mL})$ were used to synthesize $2.3 \mathrm{e}$ as a light yellow solid (26\%). ${ }^{1} \mathrm{HNMR}\left(500 \mathrm{MHz}, \mathrm{CDCl}_{3}\right): \delta 1.16(\mathrm{~s}, 9 \mathrm{H}), 2.83(\mathrm{~s}, 3 \mathrm{H}), 7.59$ $(\mathrm{d}, 1 \mathrm{H}, J=5.5 \mathrm{~Hz}), 7.74(\mathrm{t}, 1 \mathrm{H}, J=7.5 \mathrm{~Hz}), 8.17(\mathrm{~d}, 1 \mathrm{H}, J=8.0 \mathrm{~Hz}) 8.48(\mathrm{~d}, 1 \mathrm{H}, J=8.0$ $\mathrm{Hz}), 8.72(\mathrm{~s}, 1 \mathrm{H}), 8.77(\mathrm{~d}, 1 \mathrm{H}, J=5.5 \mathrm{~Hz}) . \mathrm{MS}(\mathrm{ESI}): \mathrm{m} / \mathrm{z}=390.2(\mathrm{M}+\mathrm{H})^{+}$. 
3-(2-methyl-pyrimidin-4-yl)-N-(3-trifluoromethylsulfanyl-phenyl)-

benzenesulfonamide (2.3f). Using the above procedure, 3-(2-methyl-pyrimidin-4-yl)benzenesulfonyl chloride $(0.5 \mathrm{mmol})$, 3-trifluoromethylsulfanyl-phenylamine $(0.5 \mathrm{mmol})$, PS-DMAP $(0.7 \mathrm{mmol})$, and pyridine $(3 \mathrm{~mL})$ were used to synthesize $\mathbf{2 . 3 f}$ as a light yellow solid (11\%). ${ }^{1} \mathrm{HNMR}\left(500 \mathrm{MHz}, \mathrm{CDCl}_{3}\right)$ : $\delta 2.10(\mathrm{~s}, 3 \mathrm{H}), 7.33(\mathrm{~s}, 1 \mathrm{H}), 7.38(\mathrm{~m}$, $3 \mathrm{H}) 7.64(\mathrm{t}, 1 \mathrm{H}, J=8.0 \mathrm{~Hz}), 7.91(\mathrm{~d}, 1 \mathrm{H}, J=7.5 \mathrm{~Hz}) 8.34(\mathrm{~d}, 1 \mathrm{H}, J=8.0 \mathrm{~Hz}), 8.56(\mathrm{~s}$, $1 \mathrm{H}), 8.76(\mathrm{~d}, 1 \mathrm{H}, J=5.5 \mathrm{~Hz}) . \mathrm{MS}(\mathrm{ESI}): \mathrm{m} / \mathrm{z}=448.8(\mathrm{M}+\mathrm{Na})^{+}$. HPLC2: $t_{\mathrm{R}} 3.0 \mathrm{~min}$, Purity $95 \%$.

3-[4-(3-chloro-2-cyano-phenoxy)-benzenesulfonylamino]-2-methyl-benzoic acid methyl ester (2.3g). Using the above procedure, 4-(3-chloro-2-cyano-phenoxy)benzenesulfonyl chloride $(0.5 \mathrm{mmol}), 3$-amino-2-methyl-benzoic acid methyl ester $(0.5$ mmol), PS-DMAP $(0.7 \mathrm{mmol})$, and pyridine $(3 \mathrm{~mL})$ were used to synthesize $\mathbf{2 . 3 g}$ as a light yellow solid (43\%). ${ }^{1} \mathrm{HNMR}\left(500 \mathrm{MHz}, \mathrm{CDCl}_{3}\right): \delta 2.23(\mathrm{~s}, 3 \mathrm{H}), 3.86(\mathrm{~s}, 3 \mathrm{H}), 6.86$ $(\mathrm{d}, 1 \mathrm{H}, J=7.0 \mathrm{~Hz}), 7.09(\mathrm{~d}, 2 \mathrm{H}, J=9.0 \mathrm{~Hz}), 7.20(\mathrm{t}, 1 \mathrm{H}, J=8.5 \mathrm{~Hz}), 7.31(\mathrm{~d}, 1 \mathrm{H}, J=8.0$ $\mathrm{Hz}), 7.43(\mathrm{~d}, 1 \mathrm{H}, J=8.0 \mathrm{~Hz}), 7.50(\mathrm{t}, 1 \mathrm{H}, J=8.0 \mathrm{~Hz}), 7.68(\mathrm{~d}, 1 \mathrm{H}, J=8.0 \mathrm{~Hz}), 7.74(\mathrm{~d}$, $2 \mathrm{H}, J=9.0 \mathrm{~Hz}) . \quad \mathrm{MS}(\mathrm{ESI}): \mathrm{m} / \mathrm{z}=479.3(\mathrm{M}+\mathrm{Na})^{+}$. HPLC2: $t_{\mathrm{R}} 3.1 \mathrm{~min}$, Purity $93 \%$.

$\mathrm{N}$-[2-(4-ethyl-phenyl)-ethyl]-3-(2-methyl-pyrimidin-4-yl)-benzenesulfonamide (2.3h). Using the above procedure, 3-(2-methyl-pyrimidin-4-yl)-benzenesulfonyl chloride (0.5 mmol), 2-(4-ethyl-phenyl)-ethylamine (0.5 mmol), PS-DMAP (0.7 mmol), and pyridine $(3 \mathrm{~mL})$ were used to synthesize $\mathbf{2 . 3 h}$ as a light yellow solid $(14 \%)$. ${ }^{1} \mathrm{HNMR}(500 \mathrm{MHz}$, $\left.\mathrm{CDCl}_{3}\right): \delta 1.24(\mathrm{t}, 3 \mathrm{H}, J=7.5 \mathrm{~Hz}), 2.63(\mathrm{q}, 2 \mathrm{H}, J=7.5 \mathrm{~Hz}), 2.80(\mathrm{t}, 2 \mathrm{H}, J=7.0 \mathrm{~Hz}), 2.86$ $(\mathrm{s}, 3 \mathrm{H}), 3.32(\mathrm{q}, 2 \mathrm{H}, J=6.5 \mathrm{~Hz}), 4.74(\mathrm{t}, 1 \mathrm{H}, J=6.0 \mathrm{~Hz}), 7.04(\mathrm{~d}, 2 \mathrm{H}, J=8.0 \mathrm{~Hz}), 7.12$ $(\mathrm{d}, 2 \mathrm{H}, J=8.0 \mathrm{~Hz}), 7.59(\mathrm{~d}, 1 \mathrm{H}, J=5.0 \mathrm{~Hz}), 7.69(\mathrm{t}, 1 \mathrm{H}, J=7.5 \mathrm{~Hz}), 7.98(\mathrm{~d}, 1 \mathrm{H}, J=8.0$ Hz) $8.36(\mathrm{~d}, 1 \mathrm{H}, J=8.0 \mathrm{~Hz}), 8.58(\mathrm{~s}, 1 \mathrm{H}), 8.77(\mathrm{~d}, 1 \mathrm{H}, J=5.5 \mathrm{~Hz}) . \mathrm{MS}(\mathrm{ESI}): \mathrm{m} / \mathrm{z}=$ $404.4(\mathrm{M}+\mathrm{Na})^{+}$. HPLC2: $t_{\mathrm{R}} 3.4 \mathrm{~min}$, Purity $95 \%$.

4-\{2-[3-(2-methyl-pyrimidin-4-yl)-benzenesulfonylamino]-ethyl\}-benzoic acid (2.3i). Using the above procedure, 3-(2-methyl-pyrimidin-4-yl)-benzenesulfonyl chloride $(0.5$ mmol), 4-(2-amino-ethyl)-benzoic acid (0.5 mmol), PS-DMAP (0.7 mmol), and pyridine $(3 \mathrm{~mL})$ were used to synthesize $\mathbf{2 . 3 i}$ as a light yellow solid $(22 \%)$. ${ }^{1} \mathrm{HNMR}(500 \mathrm{MHz}$, $\left.\mathrm{CDCl}_{3}\right): \delta 2.78(\mathrm{~s}, 3 \mathrm{H}), 2.82(\mathrm{t}, 2 \mathrm{H}, J=7.0 \mathrm{~Hz}), 3.25(\mathrm{~d}, 2 \mathrm{H}, J=7.5 \mathrm{~Hz}), 7.20(\mathrm{~d}, 2 \mathrm{H}, J=$ $8.0 \mathrm{~Hz}), 7.69(\mathrm{t}, 1 \mathrm{H}, J=8.0 \mathrm{~Hz}), 7.81(\mathrm{t}, 3 \mathrm{H}, J=8.0 \mathrm{~Hz}), 7.96(\mathrm{~d}, 1 \mathrm{H}, J=8.0 \mathrm{~Hz}) 8.36$ $(\mathrm{d}, 1 \mathrm{H}, J=8.0 \mathrm{~Hz}), 8.55(\mathrm{~s}, 1 \mathrm{H}), 8.75(\mathrm{~d}, 1 \mathrm{H}, J=5.5 \mathrm{~Hz}) . \mathrm{MS}(\mathrm{ESI}): \mathrm{m} / \mathrm{z}=398.3$ $(\mathrm{M}+\mathrm{H})^{+}$.

N-(2-hydroxy-1-methyl-2,2-diphenyl-ethyl)-3-(5-methyl-[1,3,4]oxadiazol-2-yl)benzenesulfonamide (2.3j). Using the above procedure, 3-(5-methyl-[1,3,4]oxadiazol-2yl)-benzenesulfonyl chloride (0.5 mmol), 2-amino-1,1-diphenyl-propan-1-ol (0.5 mmol), PS-DMAP $(0.7 \mathrm{mmol})$, and pyridine $(3 \mathrm{~mL})$ were used to synthesize $\mathbf{2 . 3} \mathbf{j}$ as a light yellow solid (17\%). ${ }^{1} \mathrm{HNMR}\left(500 \mathrm{MHz}, \mathrm{CDCl}_{3}\right): \delta 1.14(\mathrm{~d}, 3 \mathrm{H}, J=6.5 \mathrm{~Hz}), 2.63(\mathrm{~s}, 3 \mathrm{H})$, $4.48(\mathrm{~m}, 1 \mathrm{H}), 6.91(\mathrm{t}, 1 \mathrm{H}, J=7.5 \mathrm{~Hz}), 7.00(\mathrm{t}, 2 \mathrm{H}, J=8.0 \mathrm{~Hz}), 7.17(\mathrm{t}, 1 \mathrm{H}, J=7.5 \mathrm{~Hz})$, 7.27 ( t, 2H, $J=8.0 \mathrm{~Hz}), 7.34(\mathrm{~d}, 2 \mathrm{H}, J=7.0 \mathrm{~Hz}), 7.39$ (d, 2H, $J=7.5 \mathrm{~Hz}), 7.49$ (t, $1 \mathrm{H}, J$ $=8.0 \mathrm{~Hz}), 7.75(\mathrm{~d}, 1 \mathrm{H}, J=8.0 \mathrm{~Hz}), 8.13(\mathrm{~d}, 1 \mathrm{H}, J=7.5 \mathrm{~Hz}), 8.21(\mathrm{~s}, 1 \mathrm{H}) . \quad M S(E S I): \mathrm{m} / \mathrm{z}$ $=448.0(\mathrm{M}-\mathrm{H})^{-}$. HPLC2: $t_{\mathrm{R}} 2.9$ min, Purity $>99 \%$. 
$N$-(2-hydroxy-1-methyl-2,2-diphenyl-ethyl)-3-(2-methyl-pyrimidin-4-yl)benzenesulfonamide (2.3k). Using the above procedure, 3-(2-methyl-pyrimidin-4-yl)benzenesulfonyl chloride ( $0.5 \mathrm{mmol}), 2$-amino-1,1-diphenyl-propan-1-ol ( $0.5 \mathrm{mmol})$, PSDMAP $(0.7 \mathrm{mmol})$, and pyridine $(3 \mathrm{~mL})$ were used to synthesize $2.3 \mathrm{k}$ as a light yellow solid (13\%). ${ }^{1} \mathrm{HNMR}\left(500 \mathrm{MHz}, \mathrm{CDCl}_{3}\right): \delta 1.19(\mathrm{~d}, 3 \mathrm{H}, J=6.5 \mathrm{~Hz}), 2.82(\mathrm{~s}, 3 \mathrm{H}), 4.51$ $(\mathrm{m}, 1 \mathrm{H}), 5.14(\mathrm{~d}, 1 \mathrm{H}=J=8.5 \mathrm{~Hz}), 6.95(\mathrm{t}, 1 \mathrm{H}, J=7.0 \mathrm{~Hz}), 7.05(\mathrm{t}, 2 \mathrm{H}, J=7.0 \mathrm{~Hz}), 7.20$ (t, $1 \mathrm{H}, J=7.0 \mathrm{~Hz}), 7.29$ ( t, $2 \mathrm{H}, J=7.0 \mathrm{~Hz}$ ), $7.33(\mathrm{~d}, 2 \mathrm{H}, J=7.0 \mathrm{~Hz}), 7.40$ (d, $2 \mathrm{H}, J=7.0$ $\mathrm{Hz}), 7.47(\mathrm{~d}, 1 \mathrm{H}, J=5.0 \mathrm{~Hz}), 7.51(\mathrm{t}, 1 \mathrm{H}, J=8.0 \mathrm{~Hz}), 7.73(\mathrm{~d}, 1 \mathrm{H}, J=8.0 \mathrm{~Hz}) 8.27(\mathrm{~d}$, $1 \mathrm{H}, J=8.0 \mathrm{~Hz}), 8.32(\mathrm{~s}, 1 \mathrm{H}), 8.67(\mathrm{~d}, 1 \mathrm{H}, J=5.0 \mathrm{~Hz}) . \mathrm{MS}(\mathrm{ESI}): \mathrm{m} / \mathrm{z}=458.0(\mathrm{M}-\mathrm{H})$. HPLC2: $t_{\mathrm{R}} 3.1 \mathrm{~min}$, Purity $80 \%$.

\section{4-(3-chloro-2-cyano-phenoxy)-N-[2-hydroxy-1-(4-hydroxy-benzyl)-ethyl]-}

benzenesulfonamide (2.31). Using the above procedure, 4-(3-chloro-2-cyano-phenoxy)benzenesulfonyl chloride ( $0.5 \mathrm{mmol}), 4$-(2-amino-3-hydroxy-propyl)-phenol $(0.5 \mathrm{mmol})$, PS-DMAP $(0.7 \mathrm{mmol})$, and pyridine $(3 \mathrm{~mL})$ were used to synthesize 2.31 as a light yellow solid (15\%). ${ }^{1} \mathrm{HNMR}\left(500 \mathrm{MHz}, \mathrm{CDCl}_{3}\right): \delta 2.45(\mathrm{dd}, 1 \mathrm{H}, J=8.0,8.0 \mathrm{~Hz}), 2.83(\mathrm{dd}, 1 \mathrm{H}$, $J=5.5,6.0 \mathrm{~Hz}), 3.32(\mathrm{~m}, 1 \mathrm{H}), 3.46(\mathrm{dd}, 1 \mathrm{H}, J=6.0,6.0 \mathrm{~Hz}), 3.57(\mathrm{dd}, 1 \mathrm{H}, J=5.0,5.0$ $\mathrm{Hz}), 6.60(\mathrm{~d}, 2 \mathrm{H}, J=9.0 \mathrm{~Hz}), 6.99(\mathrm{~d}, 2 \mathrm{H}, J=8.5 \mathrm{~Hz}), 7.07(\mathrm{~d}, 1 \mathrm{H}, J=8.0 \mathrm{~Hz}), 7.10(\mathrm{~d}$, $2 \mathrm{H}, J=6.5 \mathrm{~Hz}), 7.46(\mathrm{~d}, 1 \mathrm{H}, J=8.5 \mathrm{~Hz}), 7.66(\mathrm{t}, 1 \mathrm{H}, J=8.5 \mathrm{~Hz}), 7.68(\mathrm{~d}, 2 \mathrm{H}, J=8.5$ $\mathrm{Hz})$. MS(ESI): $\mathrm{m} / \mathrm{z}=459.1(\mathrm{M}+\mathrm{H})^{+}$. HPLC2: $t_{\mathrm{R}} 2.8 \mathrm{~min}$, Purity $93 \%$.

General procedure for the synthesis of bromo-benzene sulfonamide intermediates (2.6a-k). To a carousel tube dichloromethane (DCM) $(5 \mathrm{~mL})$ was added. Next, 4benzene sulfonyl chloride (1.0 eq) was added followed by di-isopropylethylamine (DIPEA) (3.0 eq). Finally, appropriate primary amines (1.0 eq) were added drop-wise to the mixture. The mixture was allowed to stir at room temperature overnight. The mixtures were concentrated in vacuo. Flash column purification (0-100\% Petroleum Ether/ Ethyl Acetate) yielded the corresponding bromo-benzene sulfonamide intermediates.

4-bromo-N-[2-(3,4-dimethoxy-phenyl)-ethyl]-benzenesulfonamide (2.6a). Using the above procedure, 4-benzenesulfonylchloride $(5.0 \mathrm{mmol}), 3,4$-dimethoxy phenethylamine (5.0 mmol), DIPEA (3.0 eq), and DCM $(5 \mathrm{~mL})$ were used to synthesize $\mathbf{2 . 6 a}$ as a white solid (90\%). ${ }^{1} \mathrm{HNMR}\left(500 \mathrm{MHz}, \mathrm{CDCl}_{3}\right): \delta 2.71(\mathrm{t}, 2 \mathrm{H}, J=7.0 \mathrm{~Hz}), 3.19(\mathrm{q}, 2 \mathrm{H}, J=7.0$ $\mathrm{Hz}), 3.80(\mathrm{~s}, 3 \mathrm{H}), 3.83(\mathrm{~s}, 3 \mathrm{H}), 4.95(\mathrm{t}, 1 \mathrm{H}, J=5.8 \mathrm{~Hz}), 6.58(\mathrm{~s}, 1 \mathrm{H}), 6.61(\mathrm{~d}, 1 \mathrm{H}, J=8.0$ $\mathrm{Hz}), 6.74(\mathrm{~d}, 1 \mathrm{H}, J=8.0 \mathrm{~Hz}), 7.60(\mathrm{~d}, 2 \mathrm{H}, J=8.5 \mathrm{~Hz}), 7.64(\mathrm{~d}, 2 \mathrm{H}, J=8.0 \mathrm{~Hz})$. MS(ESI): $\mathrm{m} / \mathrm{z}=422.2,424.1(\mathrm{M}+\mathrm{Na})^{+}$. HPLC2: $t_{\mathrm{R}} 13.0 \mathrm{~min}$, Purity $>99 \%$.

4-bromo-N-(1-hydroxymethyl-propyl)-benzenesulfonamide (2.6b). Using the above procedure, 4-benzenesulfonylchloride $(5.0 \mathrm{mmol})$, 2-amino-1-butanol $(5.0 \mathrm{mmol})$, DIPEA (3.0 eq), and DCM (5mL) were used to synthesize $\mathbf{2 . 6 \mathbf { b }}$ as a white semisolid (45\%). ${ }^{1} \mathrm{HNMR}(500 \mathrm{MHz}, \mathrm{MeOD}): \delta 0.78(\mathrm{t}, 3 \mathrm{H}, J=7.5 \mathrm{~Hz}), 1.42(\mathrm{~m}, 1 \mathrm{H}), 1.52(\mathrm{~m}$, $1 \mathrm{H}), 3.20(\mathrm{~m}, 1 \mathrm{H}), 3.53(\mathrm{~m}, 1 \mathrm{H}), 3.59(\mathrm{~m}, 1 \mathrm{H}), 4.88(\mathrm{~d}, \mathrm{NH}, J=8.5 \mathrm{~Hz}), 7.66(\mathrm{~d}, 2 \mathrm{H}, J=$ $9.0 \mathrm{~Hz}), 7.76(\mathrm{~d}, 2 \mathrm{H}, J=8.5 \mathrm{~Hz}) . \mathrm{MS}(\mathrm{ESI}): \mathrm{m} / \mathrm{z}=330.0,332.0(\mathrm{M}+\mathrm{Na})^{+}$. HPLC2: $t_{\mathrm{R}}$ 11.2 min, Purity $>99 \%$. 
4-bromo-N-pyridin-2-ylmethyl-benzenesulfonamide (2.6c). Using the above procedure, 4-benzenesulfonylchloride $(5.0 \mathrm{mmol}), 2$-Pyridinyl methylamine $(5.0 \mathrm{mmol})$, DIPEA (3.0 eq), and DCM (5mL) were used to synthesize $\mathbf{2 . 6 c}$ as a light yellow solid (67\%). ${ }^{1} \mathrm{HNMR}(300 \mathrm{MHz}, \mathrm{DMSO}): \delta 5.16(\mathrm{~s}, 2 \mathrm{H}), 7.27$ (d, 1H, $\left.J=12.5 \mathrm{~Hz}\right), 7.71$ (t, $1 \mathrm{H}, J=13.5 \mathrm{~Hz}), 7.78(\mathrm{~d}, 1 \mathrm{H}, J=13.0 \mathrm{~Hz}), 7.84(\mathrm{bs}, 4 \mathrm{H}), 8.40(\mathrm{~d}, 1 \mathrm{H}, J=8.5 \mathrm{~Hz})$. MS(ESI): $\mathrm{m} / \mathrm{z}=326.0(\mathrm{M}-\mathrm{H})^{-}$. HPLC2: $t_{\mathrm{R}} 14.5 \mathrm{~min}$, Purity $95 \%$.

4-bromo-N-(3,4,5-trimethoxy-benzyl)-benzenesulfonamide (2.6d). Using the above procedure, 4-benzenesulfonylchloride $(5.0 \mathrm{mmol})$, 3,4,5-tremethozyl benzylamine (5.0 mmol), DIPEA (3.0 eq), and DCM (5mL) were used to synthesize $\mathbf{2 . 6 d}$ as a light yellow solid (92\%). ${ }^{1} \mathrm{HNMR}\left(500 \mathrm{MHz}, \mathrm{CDCl}_{3}\right): \delta 3.77(\mathrm{~s}, 6 \mathrm{H}), 3.80(\mathrm{~s}, 3 \mathrm{H}), 4.08(\mathrm{~d}, 2 \mathrm{H}, J=$ $6.0 \mathrm{~Hz}), 4.98(\mathrm{bs}, 1 \mathrm{H}), 6.35(\mathrm{~s}, 2 \mathrm{H}), 7.65(\mathrm{~d}, 2 \mathrm{H}, J=8.5 \mathrm{~Hz}), 7.72(\mathrm{~d}, 2 \mathrm{H}, J=8.5 \mathrm{~Hz})$. MS(ESI): $\mathrm{m} / \mathrm{z}=440.1(\mathrm{M}+\mathrm{Na})^{+}$. HPLC2: $t_{\mathrm{R}} 12.5 \mathrm{~min}$, Purity $97 \%$.

4-bromo-N-(2-methoxymethyl-pyrrolidin-1-yl)-benzenesulfonamide (2.6e). Using the above procedure, 4-benzenesulfonylchloride $(5.0 \mathrm{mmol}), 2-M e t h o x y m e t h y l-$ pyrrolidin-1-ylamine (5.0 mmol), DIPEA (3.0 eq), and DCM $(5 \mathrm{~mL})$ were used to synthesize 2.6e as a light yellow solid $(67 \%) .{ }^{1} \mathrm{HNMR}\left(500 \mathrm{MHz}, \mathrm{CDCl}_{3}\right): \delta 1.49(1 \mathrm{H}$, $\mathrm{m}), 1.66(\mathrm{~m}, 2 \mathrm{H}), 1.84(\mathrm{~m}, 1 \mathrm{H}), 2.55(\mathrm{q}, 1 \mathrm{H}, J=10 \mathrm{~Hz}), 2.86(\mathrm{~m}, 1 \mathrm{H}), 2.94(\mathrm{~m}, 1 \mathrm{H}), 3.13$ $(\mathrm{dd}, 1 \mathrm{H}, J=6.5,10.0 \mathrm{~Hz}), 3.18(\mathrm{~s}, 3 \mathrm{H}), 3.23(\mathrm{dd}, 1 \mathrm{H}, J=5.0,10.0 \mathrm{~Hz}), 7.66(\mathrm{~d}, 2 \mathrm{H}, J=$ $9.0 \mathrm{~Hz}), 7.83(\mathrm{~d}, 2 \mathrm{H}, J=9.0 \mathrm{~Hz}) . \mathrm{MS}(\mathrm{ESI}): \mathrm{m} / \mathrm{z}=349.1,351.1(\mathrm{M}+\mathrm{H})^{+}$. HPLC2: $t_{\mathrm{R}}$ 12.4 min, Purity $73 \%$.

4-bromo-N-(2-piperidin-1-yl-ethyl)-benzenesulfonamide (2.6f). Using the above procedure, 4-benzenesulfonylchloride $(5.0 \mathrm{mmol}), 2$-Piperidinyl ethylamine $(5.0 \mathrm{mmol})$, DIPEA (3.0 eq), and DCM (5mL) were used to synthesize $\mathbf{2 . 6 f}$ as a light yellow solid $(60 \%) .{ }^{1} \mathrm{HNMR}\left(500 \mathrm{MHz}, \mathrm{CDCl}_{3}\right): \delta 1.39(\mathrm{bs}, 2 \mathrm{H}), 1.47(\mathrm{~m}, 4 \mathrm{H}), 2.24(\mathrm{bs}, 4 \mathrm{H}), 2.34(\mathrm{t}$, $2 \mathrm{H}, \mathrm{J}=6.0 \mathrm{~Hz}), 2.97(\mathrm{t}, 2 \mathrm{H}, J=6.0 \mathrm{~Hz}), 7.66(\mathrm{~d}, 2 \mathrm{H}, J=8.5 \mathrm{~Hz}), 7.75(\mathrm{~d}, 2 \mathrm{H}, J=8.5$ Hz). MS(ESI): $\mathrm{m} / \mathrm{z}=348.8(\mathrm{M}+\mathrm{H})^{+}$. HPLC2: $t_{\mathrm{R}} 11.0 \mathrm{~min}$, Purity $80 \%$.

4-bromo-N-furan-2-ylmethyl-benzenesulfonamide (2.6g). Using the above procedure, 4-benzenesulfonylchloride (5.0 mmol), furfuranylamine (5.0 mmol), DIPEA (3.0 eq), and $\operatorname{DCM}(5 \mathrm{~mL})$ were used to synthesize $\mathbf{2 . 6 g}$ as a white solid $(93 \%) .{ }^{1} \mathrm{HNMR}(500 \mathrm{MHz}$, $\left.\mathrm{CDCl}_{3}\right): \delta 4.20(\mathrm{~d}, 2 \mathrm{H}, J=6.0 \mathrm{~Hz}), 5.08(\mathrm{t}, 1 \mathrm{H}, J=6.0 \mathrm{~Hz}), 6.09(\mathrm{~d}, 1 \mathrm{H}, J=3.5 \mathrm{~Hz})$, $6.21(\mathrm{t}, 1 \mathrm{H}, J=3.0 \mathrm{~Hz}), 7.21(\mathrm{~d}, 1 \mathrm{H}, J=2.0 \mathrm{~Hz}), 7.59(\mathrm{~d}, 2 \mathrm{H}, J=9.0 \mathrm{~Hz}), 7.66(\mathrm{~d}, 2 \mathrm{H}, J$ $=8.5 \mathrm{~Hz}) . \mathrm{MS}(\mathrm{ESI}): \mathrm{m} / \mathrm{z}=337.1,339.1(\mathrm{M}+\mathrm{Na})^{+}$. HPLC2: $t_{\mathrm{R}} 12.5 \mathrm{~min}$, Purity $>99 \%$.

4-bromo-N-[3-(2-oxo-pyrrolidin-1-yl)-propyl]-benzenesulfonamide (2.6h). Using the above procedure, 4-benzenesulfonylchloride $(5.0 \mathrm{mmol}), 1$-(3-Amino-propyl)-pyrrolidin2-one $(5.0 \mathrm{mmol})$, DIPEA (3.0 eq), and DCM $(5 \mathrm{~mL})$ were used to synthesize $\mathbf{2 . 6 h}$ as a white solid (78\%). ${ }^{1} \mathrm{HNMR}\left(500 \mathrm{MHz}, \mathrm{CDCl}_{3}\right): \delta 1.70(\mathrm{~m}, 2 \mathrm{H}), 2.01(\mathrm{~m}, 2 \mathrm{H}), 2.35(\mathrm{t}$, $2 \mathrm{H}, J=8.0 \mathrm{~Hz}), 2.87(\mathrm{q}, 2 \mathrm{H}, J=7.0 \mathrm{~Hz}), 3.33(\mathrm{~m}, 4 \mathrm{H}), 6.33(\mathrm{t}, 2 \mathrm{H}, J=8.0 \mathrm{~Hz}), 7.74(\mathrm{~d}$, $2 \mathrm{H}, J=8.5 \mathrm{~Hz})$. MS(ESI): $\mathrm{m} / \mathrm{z}=383.5(\mathrm{M}+\mathrm{Na})^{+}$. HPLC2: $t_{\mathrm{R}} 11.8 \mathrm{~min}$, Purity $>99 \%$.

4-bromo-N-(6-methoxy-pyrimidin-4-yl)-benzenesulfonamide (2.6i). Using the above procedure, 4-benzenesulfonylchloride $(5.0 \mathrm{mmol})$, 6-methoxy-4-pyrimidine $(5.0 \mathrm{mmol})$, 
DIPEA (3.0 eq), and DCM (5mL) were used to synthesize 2.6i as a light yellow solid (83\%). ${ }^{1} \mathrm{HNMR}\left(500 \mathrm{MHz}, \mathrm{CDCl}_{3}\right): \delta 3.97(\mathrm{~s}, 3 \mathrm{H}), 6.51(\mathrm{~s}, 1 \mathrm{H}), 7.64(\mathrm{~d}, 2 \mathrm{H}, J=9.0$ $\mathrm{Hz}), 7.78(\mathrm{~d}, 2 \mathrm{H}, J=8.5 \mathrm{~Hz}), 8.59(\mathrm{~s}, 1 \mathrm{H}) . \mathrm{MS}(\mathrm{ESI}): \mathrm{m} / \mathrm{z}=365.0,367.0(\mathrm{M}+\mathrm{Na})^{+}$. HPLC2: $t_{\mathrm{R}} 11.5 \mathrm{~min}$, Purity $>99 \%$.

$\mathrm{N}$-benzothiazol-6-yl-4-bromo-benzenesulfonamide (2.6j). Using the above procedure, 4-benzenesulfonylchloride $(5.0 \mathrm{mmol})$, benzothiazol-6-ylamine (5.0 mmol), DIPEA (3.0 eq), and DCM $(5 \mathrm{~mL})$ were used to synthesize $\mathbf{2 . 6 j}$ as a light yellow solid $(69 \%)$. ${ }^{1} \mathrm{HNMR}$ (500MHz, DMSO): $\delta 7.25(\mathrm{dd}, 1 \mathrm{H}, \mathrm{J}=2.0,8.5 \mathrm{~Hz}), 7.50(\mathrm{t}, 1 \mathrm{H}, \mathrm{J}=8.5 \mathrm{~Hz}), 7.75(\mathrm{~d}$, $1 \mathrm{H}, \mathrm{J}=7.5 \mathrm{~Hz}), 7.83(\mathrm{~d}, 1 \mathrm{H}, \mathrm{J}=7.5 \mathrm{~Hz}), 7.90(\mathrm{~d}, 1 \mathrm{H}, J=2.0 \mathrm{~Hz}), 7.92(\mathrm{~d}, 1 \mathrm{H}, J=2.0$ $\mathrm{Hz}), 7.98(\mathrm{t}, 1 \mathrm{H}, \mathrm{J}=9.0 \mathrm{~Hz}), 9.29(\mathrm{~s}, 1 \mathrm{H}) . \mathrm{MS}(\mathrm{ESI}): \mathrm{m} / \mathrm{z}=368.4(\mathrm{M}-\mathrm{H})^{-} . \mathrm{HPLC} 2: t_{\mathrm{R}}$ 19.3 min, Purity $>99 \%$.

2-(4-bromo-benzenesulfonylamino)-3-phenyl-propionic acid methyl ester (2.6k). Using the above procedure, 4-benzenesulfonylchloride $(5.0 \mathrm{mmol}), 2$-amino-3-phenylpropionic acid methyl ester (5.0 mmol), DIPEA (3.0 eq), and DCM (5mL) were used to synthesize 2.6k as a white solid $(44 \%)$. ${ }^{1} \mathrm{HNMR}\left(500 \mathrm{MHz}, \mathrm{CDCl}_{3}\right): \delta 2.99(\mathrm{dd}, 1 \mathrm{H}, \mathrm{J}=$ 6.5, 14.0 Hz), $3.07(\mathrm{dd}, 1 \mathrm{H}, \mathrm{J}=5.5,14.0 \mathrm{~Hz}), 3.56(\mathrm{~s}, 3 \mathrm{H}), 4.19(\mathrm{~m}, 1 \mathrm{H}), 5.39(\mathrm{~d}, 1 \mathrm{H}, \mathrm{J}=$ $9.0 \mathrm{~Hz}), 7.06(\mathrm{~m}, 2 \mathrm{H}), 7.24(\mathrm{~m}, 3 \mathrm{H}), 7.54(\mathrm{~d}, 2 \mathrm{H}, J=8.5 \mathrm{~Hz}), 7.56(\mathrm{~d}, 2 \mathrm{H}, \mathrm{J}=8.5 \mathrm{~Hz})$. MS(ESI): $\mathrm{m} / \mathrm{z}=420.2(\mathrm{M}+\mathrm{Na})^{+}$. HPLC2: $t_{\mathrm{R}} 13.4 \mathrm{~min}$, Purity $81 \%$.

General procedure for the synthesis of second generation bi-aryl libraries (2.8). In a $10 \mathrm{~mL}$ microwave tube with a stir bar were added sulfonamide intermediate (1.0 eq), aryl boronic acid (1.2 eq), sodium carbonate (3.0 eq), polymer supported tetrakistriphenylphosphine palladium catalyst (PS- $\mathrm{Pd}\left(\mathrm{Ph}_{3}\right) 4,10 \%$ mol eq). While stirring, the flask was evacuated and then refilled under argon (repeated 2 times). Next, the solvent [1:1:1 DME: EtOH: $\left.\mathrm{H}_{2} \mathrm{O}, 5 \mathrm{ml}\right]$ was added. The flask was again evacuated and refilled under argon. The microwave tube was then inserted into the microwave synthesis instrument. Reaction conditions: $100 \mathrm{~W}, 150^{\circ} \mathrm{C}, 100 \mathrm{psi}, 10 \mathrm{~min}$. After $10 \mathrm{~min}$ the mixture was cooled to room temperature. The mixture was then filtered and concentrated. All compounds were purified via preparative HPLC (20-100\%, $\mathrm{H}_{2} 0$ with $0.5 \%$ TFA:ACN).

3'-fluoro-4'-methoxy-biphenyl-4-sulfonic acid [2-(3,4-dimethoxy-phenyl)-ethyl]amide (2.8ab). Using the above general procedure, 4-bromo-N-[2-(3,4-dimethoxyphenyl)-ethyl]-benzenesulfonamide $(0.25 \mathrm{mmol})$, (3-fluoro-4-methoxyphenylboronic acid $(0.30 \mathrm{mmol})$, sodium carbonate $(0.75 \mathrm{mmol}), \mathrm{PS}-\mathrm{Pd}\left(\mathrm{Ph}_{3}\right)_{4}(0.025 \mathrm{mmol})$ and

DME:EtOH: $\mathrm{H}_{2} \mathrm{O}(5 \mathrm{~mL})$ were used to synthesize $\mathbf{2 . 8 a b}$ as a white solid $(73 \%) .{ }^{1} \mathrm{HNMR}$ $\left(500 \mathrm{MHz}, \mathrm{CDCl}_{3}\right): \delta 2.62(\mathrm{t}, 2 \mathrm{H}, J=7.5 \mathrm{~Hz}), 2.98(\mathrm{t}, 2 \mathrm{H}, J=7.5 \mathrm{~Hz}), 3.68(\mathrm{~s}, 3 \mathrm{H}), 3.69$ $(\mathrm{s}, 3 \mathrm{H}), 3.90(\mathrm{~s}, 3 \mathrm{H}), 6.65(\mathrm{~d}, 1 \mathrm{H}, J=8.0 \mathrm{~Hz}), 6.74(\mathrm{~s}, 1 \mathrm{H}), 6.81(\mathrm{~d}, 1 \mathrm{H}, J=8.0 \mathrm{~Hz}), 7.29$ $(\mathrm{t}, 1 \mathrm{H}, J=9.5 \mathrm{~Hz}), 7.57(\mathrm{~d}, 1 \mathrm{H}, J=8.5 \mathrm{~Hz}), 7.67(\mathrm{~d}, 1 \mathrm{H}, J=15.0 \mathrm{~Hz}), 7.79(\mathrm{~d}, 2 \mathrm{H}, J=$ $8.5 \mathrm{~Hz}), 7.85(\mathrm{~d}, 2 \mathrm{H}, J=8.5 \mathrm{~Hz}) . \mathrm{MS}(\mathrm{ESI}): \mathrm{m} / \mathrm{z}=446.1(\mathrm{M}+\mathrm{H})^{+}$. HPLC2: $t_{\mathrm{R}} 13.8 \mathrm{~min}$, Purity $>99 \%$.

4'-[2-(3,4-dimethoxy-phenyl)-ethylsulfamoyl]-biphenyl-4-carboxylic acid (2.8ac). Using the above general procedure, 4-bromo-N-[2-(3,4-dimethoxy-phenyl)-ethyl]- 
benzenesulfonamide $(0.25 \mathrm{mmol})$, 4-carboxylphenylboronic acid $(0.30 \mathrm{mmol})$, sodium carbonate $(0.75 \mathrm{mmol}), \mathrm{PS}-\mathrm{Pd}\left(\mathrm{Ph}_{3}\right)_{4}(0.025 \mathrm{mmol})$ and DME:EtOH: $\mathrm{H}_{2} \mathrm{O}(5 \mathrm{~mL})$ were used to synthesize $2.8 \mathrm{ac}$ as a light yellow solid $(65 \%) .{ }^{1} \mathrm{HNMR}\left(500 \mathrm{MHz}, \mathrm{CDCl}_{3}\right): \delta$ $2.75(\mathrm{t}, 2 \mathrm{H}, J=6.5 \mathrm{~Hz}), 3.23(\mathrm{t}, 2 \mathrm{H}, J=6.5 \mathrm{~Hz}), 3.81(\mathrm{~s}, 3 \mathrm{H}), 3.84(\mathrm{~s}, 3 \mathrm{H}), 6.62(\mathrm{~s}, 1 \mathrm{H})$, $6.66(\mathrm{~d}, 1 \mathrm{H}, J=8.5 \mathrm{~Hz}), 6.78(\mathrm{~d}, 1 \mathrm{H}, J=8.0 \mathrm{~Hz}), 7.68(\mathrm{~d}, 2 \mathrm{H}, J=8.0 \mathrm{~Hz}), 7.73(\mathrm{~d}, 2 \mathrm{H}, J$ $=8.5 \mathrm{~Hz}), 7.87(\mathrm{~d}, 2 \mathrm{H}, J=8.0 \mathrm{~Hz}), 8.16(\mathrm{~d}, 2 \mathrm{H}, J=8.0 \mathrm{~Hz}) . \mathrm{MS}(\mathrm{ESI}): \mathrm{m} / \mathrm{z}=442.1$ $(\mathrm{M}+\mathrm{H})^{+}$. HPLC2: $t_{\mathrm{R}} 12.7 \mathrm{~min}$, Purity $>99 \%$.

4-benzo[1,3]dioxol-5-yl-N-[2-(3,4-dimethoxy-phenyl)-ethyl]-benzenesulfonamide (2.8ae). Using the above general procedure, 4-bromo-N-[2-(3,4-dimethoxy-phenyl)ethyl]-benzenesulfonamide $(0.25 \mathrm{mmol}), 1,3$-benxodioxol-5-ylboronic acid $(0.30 \mathrm{mmol})$, sodium carbonate $(0.75 \mathrm{mmol}), \mathrm{PS}-\mathrm{Pd}\left(\mathrm{Ph}_{3}\right)_{4}(0.025 \mathrm{mmol})$ and DME:EtOH: $\mathrm{H}_{2} \mathrm{O}(5 \mathrm{~mL})$ were used to synthesize 2.8ae as a white solid $(82 \%) .{ }^{1} \mathrm{HNMR}\left(500 \mathrm{MHz}, \mathrm{CDCl}_{3}\right)$ : $\delta$ $2.70(\mathrm{t}, 2 \mathrm{H}, J=7.0 \mathrm{~Hz}), 3.14(\mathrm{t}, 2 \mathrm{H}, J=7.0 \mathrm{~Hz}), 3.76(\mathrm{~s}, 3 \mathrm{H}), 3.77(\mathrm{~s}, 3 \mathrm{H}), 6.03(\mathrm{~s}, 2 \mathrm{H})$, $6.68(\mathrm{~d}, 1 \mathrm{H}, J=8.5 \mathrm{~Hz}) 6.72(\mathrm{~s}, 1 \mathrm{H}), 6.82(\mathrm{~d}, 1 \mathrm{H}, J=8.5 \mathrm{~Hz}), 6.94(\mathrm{~d}, 1 \mathrm{H}, J=7.5 \mathrm{~Hz})$, 7.20 (d, $1 \mathrm{H}, J=7.5 \mathrm{~Hz}), 7.21(\mathrm{~s}, 1 \mathrm{H}), 7.70(\mathrm{~d}, 2 \mathrm{H}, J=8.5 \mathrm{~Hz}), 7.79$ (d, 2H, $J=8.5 \mathrm{~Hz})$. MS(ESI): $\mathrm{m} / \mathrm{z}=442.1(\mathrm{M}+\mathrm{H})^{+}$. HPLC2: $t_{\mathrm{R}} 13.7 \mathrm{~min}$, Purity $82 \%$.

\section{$N$-[2-(3,4-dimethoxy-phenyl)-ethyl]-4-(3,5-dimethyl-isoxazol-4-yl)-}

benzenesulfonamide (2.8af). Using the above general procedure, 4-bromo-N-[2-(3,4dimethoxy-phenyl)-ethyl]-benzenesulfonamide $(0.25 \mathrm{mmol}), 3,5$-dimethyl-4isoxazolylboronic acid $(0.30 \mathrm{mmol})$, sodium carbonate $(0.75 \mathrm{mmol}), \mathrm{PS}-\mathrm{Pd}\left(\mathrm{Ph}_{3}\right)_{4}(0.025$ mmol) and DME:EtOH: $\mathrm{H}_{2} \mathrm{O}(5 \mathrm{~mL})$ were used to synthesize 2.8af as a white solid (75\%). ${ }^{1} \mathrm{HNMR}\left(500 \mathrm{MHz}, \mathrm{CDCl}_{3}\right): \delta 2.31(\mathrm{~s}, 3 \mathrm{H}), 2.48(\mathrm{~s}, 3 \mathrm{H}), 2.72(\mathrm{t}, 2 \mathrm{H}, J=7.0$ $\mathrm{Hz}), 3.16(\mathrm{t}, 2 \mathrm{H}, J=7.0 \mathrm{~Hz}), 3.79(\mathrm{~s}, 3 \mathrm{H}), 3.80(\mathrm{~s}, 3 \mathrm{H}), 6.71(\mathrm{~d}, 1 \mathrm{H}, J=8.0 \mathrm{~Hz}), 6.78(\mathrm{~s}$, $1 \mathrm{H}), 6.85(\mathrm{~d}, 1 \mathrm{H}, J=8.0 \mathrm{~Hz}), 7.55(\mathrm{~d}, 2 \mathrm{H}, J=8.5 \mathrm{~Hz}), 7.90(\mathrm{~d}, 2 \mathrm{H}, J=8.5 \mathrm{~Hz})$. MS(ESI): $\mathrm{m} / \mathrm{z}=417.2(\mathrm{M}+\mathrm{H})^{+}$. HPLC2: $t_{\mathrm{R}} 12.8 \mathrm{~min}$, Purity $>99 \%$.

\section{4-(2,4-dihydroxy-pyrimidin-5-yl)-N-[2-(3,4-dimethoxy-phenyl)-ethyl]-}

benzenesulfonamide (2.8ag). Using the above general procedure, 4-bromo- $\mathrm{N}-[2-(3,4-$ dimethoxy-phenyl)-ethyl]-benzenesulfonamide $(0.25 \mathrm{mmol}), 2,4$-dioxoheahyropyrimidin5 -yl boronic acid $(0.30 \mathrm{mmol})$, sodium carbonate $(0.75 \mathrm{mmol}), \mathrm{PS}-\mathrm{Pd}\left(\mathrm{Ph}_{3}\right)_{4}(0.025$ mmol) and DME:EtOH: $\mathrm{H}_{2} \mathrm{O}(5 \mathrm{~mL})$ were used to synthesize 2.8ag as a white solid (57\%). ${ }^{1} \mathrm{HNMR}\left(500 \mathrm{MHz}, \mathrm{CDCl}_{3}\right): \delta 2.69(\mathrm{t}, 2 \mathrm{H}, J=7.5 \mathrm{~Hz}), 3.16(\mathrm{t}, 2 \mathrm{H}, J=7.0 \mathrm{~Hz})$, $3.77(\mathrm{~s}, 3 \mathrm{H}), 3.80(\mathrm{~s}, 3 \mathrm{H}), 6.68(\mathrm{~d}, 1 \mathrm{H}, J=8.5 \mathrm{~Hz}), 6.70(\mathrm{~s}, 1 \mathrm{H}), 6.83(\mathrm{~d}, 1 \mathrm{H}, J=8.0 \mathrm{~Hz})$, $7.71(\mathrm{~d}, 2 \mathrm{H}, J=8.5 \mathrm{~Hz}), 7.76(\mathrm{~d}, 2 \mathrm{H}, J=8.5 \mathrm{~Hz}), 7.76(\mathrm{~s}, 1 \mathrm{H}) . \mathrm{MS}(\mathrm{ESI}): \mathrm{m} / \mathrm{z}=432.3$ $(\mathrm{M}+\mathrm{H})^{+}$. HPLC2: $t_{\mathrm{R}} 10.6$ min, Purity $>99 \%$.

\section{$N$-[2-(3,4-dimethoxy-phenyl)-ethyl]-4-(5-formyl-furan-2-yl)-benzenesulfonamide} (2.8ah). Using the above general procedure, 4-bromo-N-[2-(3,4-dimethoxy-phenyl)ethyl]-benzenesulfonamide $(0.25 \mathrm{mmol}), 5$-formyl-2-furylboronic acid $(0.30 \mathrm{mmol})$, sodium carbonate $(0.75 \mathrm{mmol}), \mathrm{PS}-\mathrm{Pd}\left(\mathrm{Ph}_{3}\right)_{4}(0.025 \mathrm{mmol})$ and DME:EtOH: $\mathrm{H}_{2} \mathrm{O}(5 \mathrm{~mL})$ were used to synthesize $2.8 \mathrm{ah}$ as a light yellow solid $(52 \%)$. ${ }^{1} \mathrm{HNMR}\left(500 \mathrm{MHz}, \mathrm{CDCl}_{3}\right)$ : $\delta 2.71(\mathrm{t}, 2 \mathrm{H}, J=7.0 \mathrm{~Hz}), 3.16(\mathrm{t}, 2 \mathrm{H}, J=7.0 \mathrm{~Hz}), 3.77(\mathrm{~s}, 6 \mathrm{H}), 6.69(\mathrm{~d}, 1 \mathrm{H}, J=9.5 \mathrm{~Hz})$, $6.74(\mathrm{~s}, 1 \mathrm{H}), 6.83(\mathrm{~d}, 1 \mathrm{H}, J=8.0 \mathrm{~Hz}), 7.51(\mathrm{~d}, 1 \mathrm{H}, J=7.5 \mathrm{~Hz}), 7.71(\mathrm{~d}, 1 \mathrm{H}, J=8.0 \mathrm{~Hz})$, 
$7.78(\mathrm{~d}, 2 \mathrm{H}, J=8.5 \mathrm{~Hz}), 7.85(\mathrm{~d}, 2 \mathrm{H}, J=8.5 \mathrm{~Hz}) . \mathrm{MS}(\mathrm{ESI}): \mathrm{m} / \mathrm{z}=438.1(\mathrm{M}+\mathrm{Na})^{+}$. HPLC2: $t_{\mathrm{R}} 13.8$ min, Purity $>99 \%$.

2'-formyl-4'-methoxy-biphenyl-4-sulfonic acid [2-(3,4-dimethoxy-phenyl)-ethyl]amide (2.8ai). Using the above general procedure, 4-bromo-N-[2-(3,4-dimethoxyphenyl)-ethyl]-benzenesulfonamide $(0.25 \mathrm{mmol}), 2$-formyl-4-methoxyphenylboronic acid $(0.30 \mathrm{mmol})$, sodium carbonate $(0.75 \mathrm{mmol}), \mathrm{PS}-\mathrm{Pd}\left(\mathrm{Ph}_{3}\right)_{4}(0.025 \mathrm{mmol})$ and

DME:EtOH: $\mathrm{H}_{2} \mathrm{O}(5 \mathrm{~mL})$ were used to synthesize 2.8ai as a white solid (63\%). ${ }^{1} \mathrm{HNMR}$ $\left(500 \mathrm{MHz}, \mathrm{CDCl}_{3}\right): \delta 2.79(\mathrm{t}, 2 \mathrm{H}, J=6.5 \mathrm{~Hz}), 3.29(\mathrm{q}, 2 \mathrm{H}, J=6.5 \mathrm{~Hz}), 3.84(\mathrm{~s}, 3 \mathrm{H})$, $3.85(\mathrm{~s}, 3 \mathrm{H}), 3.93(\mathrm{~s}, 3 \mathrm{H}), 4.67(\mathrm{t}, 1 \mathrm{H}, J=6.0 \mathrm{~Hz}), 6.66(\mathrm{~s}, 1 \mathrm{H}), 6.68(\mathrm{~d}, 1 \mathrm{H}, J=8.0 \mathrm{~Hz})$, $6.80(\mathrm{~d}, 1 \mathrm{H}, J=8.0 \mathrm{~Hz}), 7.25(\mathrm{~d}, 1 \mathrm{H}, J=8.0 \mathrm{~Hz}), 7.38(\mathrm{~d}, 1 \mathrm{H}, J=8.5 \mathrm{~Hz}), 7.47(\mathrm{~d}, 2 \mathrm{H}, J$ $=8.0 \mathrm{~Hz}), 7.54(\mathrm{~s}, 1 \mathrm{H}), 7.90(\mathrm{~d}, 2 \mathrm{H}, J=8.5 \mathrm{~Hz}), 9.92(\mathrm{~s}, 1 \mathrm{H}) . \mathrm{MS}(\mathrm{ESI}): \mathrm{m} / \mathrm{z}=478.1$ $(\mathrm{M}+\mathrm{Na})^{+}, 454.0(\mathrm{M}-\mathrm{H})^{-}$. HPLC2: $t_{\mathrm{R}} 13.5 \mathrm{~min}$, Purity $>99 \%$.

3'-fluoro-4'-methoxy-biphenyl-4-sulfonic acid (1-hydroxymethyl-propyl)-amide (2.8bb). Using the above general procedure, 4-bromo-N-(1-hydroxymethyl-propyl)benzenesulfonamide $(0.25 \mathrm{mmol})$, 3-fluoro-4-methoxyphenylboronic acid $(0.30 \mathrm{mmol})$, sodium carbonate $(0.75 \mathrm{mmol}), \mathrm{PS}-\mathrm{Pd}\left(\mathrm{Ph}_{3}\right)_{4}(0.025 \mathrm{mmol})$ and DME:EtOH: $\mathrm{H}_{2} \mathrm{O}(5 \mathrm{~mL})$ were used to synthesize $\mathbf{2 . 8 b b}$ as a white solid (72\%). ${ }^{1} \mathrm{HNMR}(300 \mathrm{MHz}, \mathrm{DMSO}): \delta$ $0.66(\mathrm{t}, 3 \mathrm{H}, J=7.5 \mathrm{~Hz}), 1.22(\mathrm{~m}, 1 \mathrm{H}), 1.55(\mathrm{~m}, 1 \mathrm{H}), 2.99(\mathrm{~m}, 1 \mathrm{H}), 3.14$ (dd, 1H, $J=7.0$, $10.0 \mathrm{~Hz}$ ), $3.27(\mathrm{dd}, 1 \mathrm{H}, J=4.5,11.0 \mathrm{~Hz}), 3.89(\mathrm{~s}, 3 \mathrm{H}), 7.28(\mathrm{t}, 1 \mathrm{H}, J=9.0 \mathrm{~Hz}), 7.58(\mathrm{~d}$, $1 \mathrm{H}, J=9.0 \mathrm{~Hz}), 7.68(\mathrm{~d}, 1 \mathrm{H}, J=13.0 \mathrm{~Hz}), 7.83(\mathrm{~d}, 2 \mathrm{H}, J=9.0 \mathrm{~Hz}), 7.87(\mathrm{~d}, 2 \mathrm{H}, J=9.0$ Hz). MS(ESI): $\mathrm{m} / \mathrm{z}=376.3(\mathrm{M}+\mathrm{Na})^{+}$. HPLC2: $t_{\mathrm{R}} 12.6 \mathrm{~min}$, Purity $95 \%$.

4'-(1-hydroxymethyl-propylsulfamoyl)-biphenyl-4-carboxylic acid (2.8bc). Using the above general procedure, 4-bromo- $\mathrm{N}$-(1-hydroxymethyl-propyl)-benzenesulfonamide $(0.25 \mathrm{mmol}), 4$-carboxylphenylboronic acid $(0.30 \mathrm{mmol})$, sodium carbonate $(0.75 \mathrm{mmol})$, PS- $\mathrm{Pd}\left(\mathrm{Ph}_{3}\right)_{4}(0.025 \mathrm{mmol})$ and DME:EtOH: $\mathrm{H}_{2} \mathrm{O}(5 \mathrm{~mL})$ were used to synthesize $\mathbf{2 . 8 b c}$ as a white solid (72\%). ${ }^{1} \mathrm{HNMR}(300 \mathrm{MHz}, \mathrm{DMSO}): \delta 0.66(\mathrm{t}, 3 \mathrm{H}, J=7.0 \mathrm{~Hz}), 1.24(\mathrm{~m}$, $1 \mathrm{H}), 1.51(\mathrm{~m}, 1 \mathrm{H}), 2.96(\mathrm{~m}, 1 \mathrm{H}), 3.16(\mathrm{dd}, 1 \mathrm{H}, J=3.0,7.0 \mathrm{~Hz}), 3.27(\mathrm{dd}, 1 \mathrm{H}, J=5.0$, $10.5 \mathrm{~Hz}), 7.66(\mathrm{~d}, 2 \mathrm{H}, J=8.0 \mathrm{~Hz}), 7.86(\mathrm{bs}, 4 \mathrm{H}), 7.99(\mathrm{~d}, 2 \mathrm{H}, J=8.0 \mathrm{~Hz}) . \quad \mathrm{MS}(\mathrm{ESI})$ : $\mathrm{m} / \mathrm{z}=350.2(\mathrm{M}+\mathrm{H})^{+}$. HPLC2: $t_{\mathrm{R}} 11.2 \mathrm{~min}$, Purity $87 \%$.

\section{5-[4-(1-hydroxymethyl-propylsulfamoyl)-phenyl]-thiophene-2-carboxylic acid} (2.8bd). Using the above general procedure, 4-bromo-N-(1-hydroxymethyl-propyl)benzenesulfonamide $(0.25 \mathrm{mmol}), 5$-(dihydroxylboryl)-2-thiophenecarboxylic acid $(0.30 \mathrm{mmol})$, sodium carbonate $(0.75 \mathrm{mmol}), \mathrm{PS}-\mathrm{Pd}\left(\mathrm{Ph}_{3}\right)_{4}(0.025 \mathrm{mmol})$ and DME:EtOH: $\mathrm{H}_{2} \mathrm{O}(5 \mathrm{~mL})$ were used to synthesize $\mathbf{2 . 8 b d}$ as a white solid $(89 \%) .{ }^{1} \mathrm{HNMR}$ (500MHz, MeOD): $\delta 0.78(\mathrm{t}, 3 \mathrm{H}, J=7.5 \mathrm{~Hz}), 1.35(\mathrm{~m}, 1 \mathrm{H}), 1.64(\mathrm{~m}, 1 \mathrm{H}), 3.20(\mathrm{~m}, 1 \mathrm{H})$, $3.37(\mathrm{dd}, 1 \mathrm{H}, J=6.0,15.0 \mathrm{~Hz}), 3.59(\mathrm{dd}, 1 \mathrm{H}, J=4.5,11.0 \mathrm{~Hz}), 7.61(\mathrm{~d}, 2 \mathrm{H}, J=3.5 \mathrm{~Hz})$, $7.80(\mathrm{~d}, 2 \mathrm{H}, J=4.0 \mathrm{~Hz}), 7.91(\mathrm{~d}, 2 \mathrm{H}, J=9.0 \mathrm{~Hz}), 7.95(\mathrm{~d}, 2 \mathrm{H}, J=8.5 \mathrm{~Hz}) . \quad \mathrm{MS}(\mathrm{ESI})$ : $\mathrm{m} / \mathrm{z}=356.1(\mathrm{M}+\mathrm{H})^{+}$. HPLC2: $t_{\mathrm{R}} 11.1 \mathrm{~min}$, Purity $>99 \%$.

4-benzo[1,3] dioxol-5-yl-N-(1-hydroxymethyl-propyl)-benzenesulfonamide (2.8be). Using the above general procedure, 4-bromo-N-(1-hydroxymethyl-propyl)benzenesulfonamide $(0.25 \mathrm{mmol}), 1,3$-benxodioxol-5-ylboronic acid $(0.30 \mathrm{mmol})$, sodium 
carbonate $(0.75 \mathrm{mmol}), \mathrm{PS}-\mathrm{Pd}\left(\mathrm{Ph}_{3}\right)_{4}(0.025 \mathrm{mmol})$ and DME:EtOH: $\mathrm{H}_{2} \mathrm{O}(5 \mathrm{~mL})$ were used to synthesize 2.8be as a white solid (62\%). ${ }^{1} \mathrm{HNMR}(300 \mathrm{MHz}, \mathrm{DMSO}): \delta 0.66(\mathrm{t}$, $3 \mathrm{H}, J=7.0 \mathrm{~Hz}), 1.22(\mathrm{~m}, 1 \mathrm{H}), 1.53(\mathrm{~m}, 1 \mathrm{H}), 2.97(\mathrm{~m}, 1 \mathrm{H}), 3.14(\mathrm{dd}, 1 \mathrm{H}, J=7.5,9.0 \mathrm{~Hz})$, $3.25(\mathrm{dd}, 1 \mathrm{H}, J=8.0,12.0 \mathrm{~Hz}), 6.06(\mathrm{~s}, 2 \mathrm{H}), 7.04$ (d, $1 \mathrm{H}, J=8.0 \mathrm{~Hz}), 7.25$ (d, $1 \mathrm{H}, J=8.0$ $\mathrm{Hz}), 7.35(\mathrm{~s}, 1 \mathrm{H}), 7.82(\mathrm{bs}, 4 \mathrm{H}) . \mathrm{MS}(\mathrm{ESI}): \mathrm{m} / \mathrm{z}=372.1(\mathrm{M}+\mathrm{Na})^{+}$. HPLC2: $t_{\mathrm{R}} 12.4 \mathrm{~min}$, Purity $92 \%$.

\section{4-(3,5-dimethyl-isoxazol-4-yl)-N-(1-hydroxymethyl-propyl)-benzenesulfonamide}

(2.8bf). Using the above general procedure, 4-bromo-N-(1-hydroxymethyl-propyl)benzenesulfonamide $(0.25 \mathrm{mmol}), 3,5$-dimethyl-4-isoxazolylboronic acid $(0.30 \mathrm{mmol})$, sodium carbonate $(0.75 \mathrm{mmol}), \mathrm{PS}-\mathrm{Pd}\left(\mathrm{Ph}_{3}\right)_{4}(0.025 \mathrm{mmol})$ and DME:EtOH: $\mathrm{H}_{2} \mathrm{O}(5 \mathrm{~mL})$ were used to synthesize $\mathbf{2 . 8 b f}$ as a white solid (69\%). ${ }^{1} \mathrm{HNMR}(500 \mathrm{MHz}, \mathrm{MeOD}): \delta$ $0.77(\mathrm{t}, 3 \mathrm{H}, J=7.5 \mathrm{~Hz}), 1.35(\mathrm{~m}, 1 \mathrm{H}), 1.64(\mathrm{~m}, 1 \mathrm{H}), 2.30(\mathrm{~s}, 3 \mathrm{H}), 2.46(\mathrm{~s}, 3 \mathrm{H}), 3.16(\mathrm{~m}$, $1 \mathrm{H}), 3.39(\mathrm{dd}, 1 \mathrm{H}, J=6.0,11.0 \mathrm{~Hz}), 3.47(\mathrm{dd}, 1 \mathrm{H}, J=4.5,15.0 \mathrm{~Hz}), 7.57(\mathrm{~d}, 2 \mathrm{H}, J=8.5$ $\mathrm{Hz}), 8.00(\mathrm{~d}, 2 \mathrm{H}, J=8.5 \mathrm{~Hz}) . \mathrm{MS}(\mathrm{ESI}): \mathrm{m} / \mathrm{z}=325.0(\mathrm{M}+\mathrm{H})^{+}$. HPLC2: $t_{\mathrm{R}} 11.1 \mathrm{~min}$, Purity $>99 \%$.

4-(2,4-dihydroxy-pyrimidin-5-yl)-N-(1-hydroxymethyl-propyl)-benzenesulfonamide (2.8bg). Using the above general procedure, 4-bromo-N-(1-hydroxymethyl-propyl)benzenesulfonamide $(0.25 \mathrm{mmol}), 2$,4-dihydroxypyrimidine-5-boronic acid $(0.30 \mathrm{mmol})$, sodium carbonate $(0.75 \mathrm{mmol}), \mathrm{PS}-\mathrm{Pd}\left(\mathrm{Ph}_{3}\right)_{4}(0.025 \mathrm{mmol})$ and DME:EtOH: $\mathrm{H}_{2} \mathrm{O}(5 \mathrm{~mL})$ were used to synthesize $\mathbf{2 . 8 b g}$ as a white solid (66\%). ${ }^{1} \mathrm{HNMR}(500 \mathrm{MHz}, \mathrm{MeOD}): \delta$ $0.78(\mathrm{t}, 3 \mathrm{H}, J=7.5 \mathrm{~Hz}), 1.34(\mathrm{~m}, 1 \mathrm{H}), 1.63(\mathrm{~m}, 1 \mathrm{H}), 3.13(\mathrm{~m}, 1 \mathrm{H}), 3.35(\mathrm{dd}, 1 \mathrm{H}, J=6.5$, $11.0 \mathrm{~Hz}), 3.45(\mathrm{dd}, 1 \mathrm{H}, J=4.5,12.0 \mathrm{~Hz}), 7.74(\mathrm{~s}, 1 \mathrm{H}), 7.78$ (d, 2H, $J=8.5 \mathrm{~Hz}), 7.89$ (d, $2 \mathrm{H}, J=9.0 \mathrm{~Hz})$. MS(ESI): $\mathrm{m} / \mathrm{z}=362.1(\mathrm{M}+\mathrm{Na})^{+}$. HPLC2: $t_{\mathrm{R}} 8.5 \mathrm{~min}$, Purity $>99 \%$.

\section{2'-formyl-4'-methoxy-biphenyl-4-sulfonic acid (1-hydroxymethyl-propyl)-amide}

(2.8bi). Using the above general procedure, 4-bromo-N-(1-hydroxymethyl-propyl)benzenesulfonamide $(0.25 \mathrm{mmol})$, 2-formyl-4-methoxyphenylboronic acid $(0.30 \mathrm{mmol})$, sodium carbonate $(0.75 \mathrm{mmol}), \mathrm{PS}-\mathrm{Pd}\left(\mathrm{Ph}_{3}\right)_{4}(0.025 \mathrm{mmol})$ and DME:EtOH: $\mathrm{H}_{2} \mathrm{O}(5 \mathrm{~mL})$ were used to synthesize 2.8bi as a white solid (63\%). ${ }^{1} \mathrm{HNMR}(300 \mathrm{MHz}, \mathrm{DMSO}): \delta$ $0.77(\mathrm{t}, 3 \mathrm{H}, J=7.5 \mathrm{~Hz}), 1.35(\mathrm{~m}, 1 \mathrm{H}), 1.64(\mathrm{~m}, 1 \mathrm{H}), 3.18(\mathrm{~m}, 1 \mathrm{H}), 3.39(\mathrm{dd}, 1 \mathrm{H}, J=6.0$, $11.0 \mathrm{~Hz}), 3.48(\mathrm{dd}, 1 \mathrm{H}, J=5.0,11.0 \mathrm{~Hz}), 3.91(\mathrm{~s}, 3 \mathrm{H}), 7.33(\mathrm{t}, 1 \mathrm{H}, J=3.0 \mathrm{~Hz}), 7.44$ (s, $1 \mathrm{H}), 7.51(\mathrm{~d}, 1 \mathrm{H}, J=3.0 \mathrm{~Hz}), 7.57(\mathrm{~d}, 2 \mathrm{H}, J=9.0 \mathrm{~Hz}), 7.99(\mathrm{~d}, 2 \mathrm{H}, J=8.5 \mathrm{~Hz}), 9.95$ (s, 1H). $\mathrm{MS}(\mathrm{ESI}): \mathrm{m} / \mathrm{z}=386.2(\mathrm{M}+\mathrm{Na})^{+}$. HPLC2: $t_{\mathrm{R}} 12.2 \mathrm{~min}$, Purity $92 \%$.

3'-fluoro-4'-methoxy-biphenyl-4-sulfonic acid (pyridin-2-ylmethyl)-amide (2.8cb). Using the above general procedure, 4-bromo-N-pyridin-2-ylmethyl-benzenesulfonamide (0.25 mmol), 3-fluoro-4-methoxyphenylboronic acid $(0.30 \mathrm{mmol})$, sodium carbonate $(0.75 \mathrm{mmol}), \mathrm{PS}-\mathrm{Pd}\left(\mathrm{Ph}_{3}\right)_{4}(0.025 \mathrm{mmol})$ and DME:EtOH: $\mathrm{H}_{2} \mathrm{O}(5 \mathrm{~mL})$ were used to synthesize $2.8 \mathrm{cb}$ as a white solid $(72 \%)$. ${ }^{1} \mathrm{HNMR}\left(500 \mathrm{MHz}, \mathrm{CDCl}_{3}\right): \delta 3.88(\mathrm{~s}, 3 \mathrm{H})$, $4.10(\mathrm{~s}, 2 \mathrm{H}), 7.22(\mathrm{t}, 1 \mathrm{H}, J=8.5 \mathrm{~Hz}), 7.30(\mathrm{t}, 1 \mathrm{H}, J=15.0 \mathrm{~Hz}), 7.38(\mathrm{~d}, 1 \mathrm{H}, J=13.0 \mathrm{~Hz})$, $7.56(\mathrm{~d}, 1 \mathrm{H}, J=14.5 \mathrm{~Hz}), 7.70(\mathrm{t}, 1 \mathrm{H}, J=14.0 \mathrm{~Hz}), 7.72(\mathrm{~d}, 1 \mathrm{H}, J=12.0 \mathrm{~Hz}), 7.82(\mathrm{bs}$, $4 \mathrm{H}), 8.42(\mathrm{~d}, 1 \mathrm{H}, J=7.0 \mathrm{~Hz}) . \mathrm{MS}(\mathrm{ESI}): \mathrm{m} / \mathrm{z}=395.3(\mathrm{M}+\mathrm{Na})^{+}$. HPLC2: $t_{\mathrm{R}} 12.2 \mathrm{~min}$, Purity $96 \%$. 
4-benzo[1,3]dioxol-5-yl-N-pyridin-2-ylmethyl-benzenesulfonamide (2.8ce). Using the above general procedure, 4-bromo-N-pyridin-2-ylmethyl-benzenesulfonamide

(0.25 mmol), 1,3-benxodioxol-5-ylboronic acid $(0.30 \mathrm{mmol})$, sodium carbonate $(0.75$

mmol), PS- $\mathrm{Pd}\left(\mathrm{Ph}_{3}\right)_{4}(0.025 \mathrm{mmol})$ and DME:EtOH: $\mathrm{H}_{2} \mathrm{O}(5 \mathrm{~mL})$ were used to synthesize

2.8ce as a white solid (84\%). ${ }^{1} \mathrm{HNMR}\left(500 \mathrm{MHz}, \mathrm{CDCl}_{3}\right): \delta 6.10(\mathrm{~s}, 2 \mathrm{H}), 7.05(\mathrm{~d}, 1 \mathrm{H}, \mathrm{J}$

$=8.0 \mathrm{~Hz}), 7.23(\mathrm{~d}, 2 \mathrm{H}, \mathrm{J}=5.0 \mathrm{~Hz}), 7.34(\mathrm{~s}, 1 \mathrm{H}), 7.37(\mathrm{~d}, 1 \mathrm{H}, \mathrm{J}=7.5 \mathrm{~Hz}), 7.72(\mathrm{t}, 1 \mathrm{H}, \mathrm{J}=$

$7.5 \mathrm{~Hz}), 7.78(\mathrm{~d}, 2 \mathrm{H}, \mathrm{J}=8.5 \mathrm{~Hz}), 7.81(\mathrm{~d}, 2 \mathrm{H}, \mathrm{J}=9.0 \mathrm{~Hz}), 8.44(\mathrm{~d}, 1 \mathrm{H}, \mathrm{J}=5.0 \mathrm{~Hz})$.

MS(ESI): $\mathrm{m} / \mathrm{z}=391.1(\mathrm{M}+\mathrm{Na})^{+}$. HPLC2: $t_{\mathrm{R}} 12.0 \mathrm{~min}$, Purity $84 \%$.

3'-fluoro-4'-methoxy-biphenyl-4-sulfonic acid 3,4,5-trimethoxy-benzylamide (2.8db). Using the above general procedure, 4-bromo-N-(3,4,5-trimethoxy-benzyl)-

benzenesulfonamide $(0.25 \mathrm{mmol}), 3$-fluoro-4-methoxyphenylboronic acid

$(0.30 \mathrm{mmol})$, sodium carbonate $(0.75 \mathrm{mmol}), \mathrm{PS}-\mathrm{Pd}\left(\mathrm{Ph}_{3}\right)_{4}(0.025 \mathrm{mmol})$ and

DME:EtOH: $\mathrm{H}_{2} \mathrm{O}(5 \mathrm{~mL})$ were used to synthesize $\mathbf{2 . 8 d b}$ as a white solid $(96 \%) .{ }^{1} \mathrm{HNMR}$ $\left(500 \mathrm{MHz}, \mathrm{CDCl}_{3}\right): \delta 3.53(\mathrm{~s}, 3 \mathrm{H}), 3.67(\mathrm{~s}, 6 \mathrm{H}), 3.90(\mathrm{~s}, 3 \mathrm{H}), 4.00(\mathrm{~s}, 2 \mathrm{H}), 6.49(\mathrm{~s}, 2 \mathrm{H})$, $7.29(\mathrm{t}, 1 \mathrm{H}, J=8.5 \mathrm{~Hz}), 7.54(\mathrm{~d}, 1 \mathrm{H}, J=8.5 \mathrm{~Hz}), 7.64(\mathrm{~d}, 1 \mathrm{H}, J=13.0 \mathrm{~Hz}), 7.78(\mathrm{~d}, 2 \mathrm{H}, J$ $=9.0 \mathrm{~Hz}), 7.81(\mathrm{~d}, 2 \mathrm{H}, J=9.0 \mathrm{~Hz}) . \mathrm{MS}(\mathrm{ESI}): \mathrm{m} / \mathrm{z}=484.1(\mathrm{M}+\mathrm{Na})^{+}$. HPLC2: $t_{\mathrm{R}} 13.5$ min, Purity $97 \%$.

4'-(3,4,5-trimethoxy-benzylsulfamoyl)-biphenyl-4-carboxylic acid (2.8dc). Using the above general procedure, 4-bromo-N-(3,4,5-trimethoxy-benzyl)-benzenesulfonamide $(0.25 \mathrm{mmol}), 4$-carboxylphenylboronic acid $(0.30 \mathrm{mmol})$, sodium carbonate $(0.75 \mathrm{mmol})$, PS- $\mathrm{Pd}\left(\mathrm{Ph}_{3}\right)_{4}(0.025 \mathrm{mmol})$ and DME:EtOH: $\mathrm{H}_{2} \mathrm{O}(5 \mathrm{~mL})$ were used to synthesize 2.8dc as a white solid (78\%). ${ }^{1} \mathrm{HNMR}\left(500 \mathrm{MHz}, \mathrm{CDCl}_{3}\right): \delta 3.51(\mathrm{~s}, 3 \mathrm{H}), 3.67(\mathrm{~s}, 6 \mathrm{H}), 4.01(\mathrm{~s}$, 2H), $6.50(\mathrm{~s}, 2 \mathrm{H}), 7.64(\mathrm{~d}, 2 \mathrm{H}, J=8.0 \mathrm{~Hz}), 7.83(\mathrm{bs}, 4 \mathrm{H}), 8.00(\mathrm{~d}, 2 \mathrm{H}, J=7.5 \mathrm{~Hz})$. MS(ESI): $\mathrm{m} / \mathrm{z}=456.0(\mathrm{M}-\mathrm{H})^{-}$. HPLC2: $t_{\mathrm{R}} 12.4 \mathrm{~min}$, Purity $93 \%$.

5-[4-(3,4,5-trimethoxy-benzylsulfamoyl)-phenyl]-thiophene-2-carboxylic acid (2.8dd). Using the above general procedure, 4-bromo-N-(3,4,5-trimethoxy-benzyl)benzenesulfonamide $(0.25 \mathrm{mmol}), 5$-(dihydroxylboryl)-2-thiophenecarboxylic acid $(0.30 \mathrm{mmol})$, sodium carbonate $(0.75 \mathrm{mmol}), \mathrm{PS}-\mathrm{Pd}\left(\mathrm{Ph}_{3}\right)_{4}(0.025 \mathrm{mmol})$ and DME:EtOH: $\mathrm{H}_{2} \mathrm{O}(5 \mathrm{~mL})$ were used to synthesize 2.8dd as a white solid (48\%). ${ }^{1} \mathrm{HNMR}$ $\left(500 \mathrm{MHz}, \mathrm{CDCl}_{3}\right): \delta 3.65(\mathrm{~s}, 3 \mathrm{H}), 3.75(\mathrm{~s}, 6 \mathrm{H}), 4.13(\mathrm{~s}, 2 \mathrm{H}), 6.47(\mathrm{~s}, 2 \mathrm{H}), 7.55(\mathrm{~d}, 1 \mathrm{H}, J$ $=4.0 \mathrm{~Hz}), 7.71(\mathrm{~d}, 1 \mathrm{H}, J=4.0 \mathrm{~Hz}), 7.82(\mathrm{bs}, 4 \mathrm{H}) . \mathrm{MS}(\mathrm{ESI}): \mathrm{m} / \mathrm{z}=486.1(\mathrm{M}+\mathrm{Na})^{+}$. HPLC2: $t_{\mathrm{R}} 12.3 \mathrm{~min}$, Purity $>99 \%$.

4-benzo[1,3]dioxol-5-yl-N-(3,4,5-trimethoxy-benzyl)-benzenesulfonamide (2.8de). Using the above general procedure, 4-bromo-N-(3,4,5-trimethoxy-benzyl)benzenesulfonamide $(0.25 \mathrm{mmol}), 1,3$-benxodioxol-5-ylboronic acid $(0.30 \mathrm{mmol})$, sodium carbonate $(0.75 \mathrm{mmol}), \mathrm{PS}-\mathrm{Pd}\left(\mathrm{Ph}_{3}\right)_{4}(0.025 \mathrm{mmol})$ and DME:EtOH: $\mathrm{H}_{2} \mathrm{O}(5 \mathrm{~mL})$ were used to synthesize $2.8 d e$ as a white solid $(68 \%)$. ${ }^{1} \mathrm{HNMR}\left(500 \mathrm{MHz}, \mathrm{CDCl}_{3}\right): \delta 3.54(\mathrm{~s}$, $3 \mathrm{H}), 3.67(\mathrm{~s}, 6 \mathrm{H}), 4.00(\mathrm{~s}, 2 \mathrm{H}), 6.10(\mathrm{~s}, 2 \mathrm{H}), 6.49(\mathrm{~s}, 2 \mathrm{H}), 7.05(\mathrm{~d}, 1 \mathrm{H}, J=8.0 \mathrm{~Hz}), 7.22$ $(\mathrm{d}, 1 \mathrm{H}, J=8.0 \mathrm{~Hz}), 7.31(\mathrm{~s}, 1 \mathrm{H}), 7.77(\mathrm{bs}, 4 \mathrm{H}) . \mathrm{MS}(\mathrm{ESI}): \mathrm{m} / \mathrm{z}=480.5(\mathrm{M}+\mathrm{Na})^{+}$. HPLC2: $t_{\mathrm{R}} 13.4 \mathrm{~min}$, Purity $>99 \%$. 
4-(3,5-dimethyl-isoxazol-4-yl)-N-(3,4,5-trimethoxy-benzyl)-benzenesulfonamide (2.8df). Using the above general procedure, 4-bromo-N-(3,4,5-trimethoxy-benzyl)benzenesulfonamide $(0.25 \mathrm{mmol}), 3,5$-dimethyl-4-isoxazolylboronic acid $(0.30 \mathrm{mmol})$, sodium carbonate $(0.75 \mathrm{mmol}), \mathrm{PS}-\mathrm{Pd}\left(\mathrm{Ph}_{3}\right)_{4}(0.025 \mathrm{mmol})$ and DME:EtOH: $\mathrm{H}_{2} \mathrm{O}(5 \mathrm{~mL})$ were used to synthesize $2.8 d f$ as a white solid $(41 \%)$. ${ }^{1} \mathrm{HNMR}\left(500 \mathrm{MHz}, \mathrm{CDCl}_{3}\right)$ : $\delta$ $2.30(\mathrm{~s}, 3 \mathrm{H}), 2.46(\mathrm{~s}, 3 \mathrm{H}), 3.68(\mathrm{~s}, 3 \mathrm{H}), 3.76(\mathrm{~s}, 6 \mathrm{H}), 4.16(\mathrm{~s}, 2 \mathrm{H}), 6.51(\mathrm{~s}, 2 \mathrm{H}), 7.47(\mathrm{~d}$, $2 \mathrm{H}, J=8.5 \mathrm{~Hz}), 7.86(\mathrm{~d}, 2 \mathrm{H}, J=8.5 \mathrm{~Hz}) . \mathrm{MS}(\mathrm{ESI}): \mathrm{m} / \mathrm{z}=430.9(\mathrm{M}-\mathrm{H})^{-}$. HPLC2: $t_{\mathrm{R}}$ 11.6 min, Purity $87 \%$.

4-(2,4-dihydroxy-pyrimidin-5-yl)-N-(3,4,5-trimethoxy-benzyl)-benzenesulfonamide (2.8dg). Using the above general procedure, 4-bromo-N-(3,4,5-trimethoxy-benzyl)benzenesulfonamide $(0.25 \mathrm{mmol}), 2,4$-dihydroxypyrimidine-5-boronic acid $(0.30 \mathrm{mmol})$, sodium carbonate $(0.75 \mathrm{mmol}), \mathrm{PS}-\mathrm{Pd}\left(\mathrm{Ph}_{3}\right)_{4}(0.025 \mathrm{mmol})$ and DME:EtOH: $\mathrm{H}_{2} \mathrm{O}(5 \mathrm{~mL})$ were used to synthesize $2.8 \mathrm{dg}$ as a white solid $(75 \%)$. ${ }^{1} \mathrm{HNMR}\left(500 \mathrm{MHz}, \mathrm{CDCl}_{3}\right)$ : $\delta$ $3.71(\mathrm{~s}, 3 \mathrm{H}), 3.76(\mathrm{~s}, 6 \mathrm{H}), 4.08(\mathrm{~s}, 2 \mathrm{H}), 6.49(\mathrm{~s}, 2 \mathrm{H}), 7.53(\mathrm{t}, 2 \mathrm{H}, J=7.5 \mathrm{~Hz}), 7.59(\mathrm{t}, 1 \mathrm{H}$, $J=7.5 \mathrm{~Hz}), 7.82(\mathrm{~d}, 2 \mathrm{H}, J=8.0 \mathrm{~Hz}) . \mathrm{MS}(\mathrm{ESI}): \mathrm{m} / \mathrm{z}=446.0(\mathrm{M}-\mathrm{H})^{-}$. HPLC2: $t_{\mathrm{R}} 11.6$ min, Purity $88 \%$.

4-(5-formyl-furan-2-yl)-N-(3,4,5-trimethoxy-benzyl)-benzenesulfonamide (2.8dh). Using the above general procedure, 4-bromo-N-(3,4,5-trimethoxy-benzyl)benzenesulfonamide $(0.25 \mathrm{mmol})$, 5-formyl-2-furylboronic acid $(0.30 \mathrm{mmol})$, sodium carbonate $(0.75 \mathrm{mmol}), \mathrm{PS}-\mathrm{Pd}\left(\mathrm{Ph}_{3}\right)_{4}(0.025 \mathrm{mmol})$ and DME:EtOH: $\mathrm{H}_{2} \mathrm{O}(5 \mathrm{~mL})$ were used to synthesize $\mathbf{2 . 8 d h}$ as a light yellow solid $(39 \%)$. ${ }^{1} \mathrm{HNMR}\left(500 \mathrm{MHz}, \mathrm{CDCl}_{3}\right)$ : $\delta$ $3.64(\mathrm{~s}, 3 \mathrm{H}), 3.76(\mathrm{~s}, 6 \mathrm{H}), 4.14(\mathrm{~s}, 2 \mathrm{H}), 6.48(\mathrm{~s}, 2 \mathrm{H}), 6.96(\mathrm{~d}, 1 \mathrm{H}, J=3.0 \mathrm{~Hz}), 7.25(\mathrm{~d}, 1 \mathrm{H}$, $J=4.0 \mathrm{~Hz}), 7.86(\mathrm{~d}, 2 \mathrm{H}, J=8.5 \mathrm{~Hz}), 7.98(\mathrm{~d}, 2 \mathrm{H}, J=8.5 \mathrm{~Hz}) . \mathrm{MS}(\mathrm{ESI}): \mathrm{m} / \mathrm{z}=454.6$ $(\mathrm{M}+\mathrm{Na})^{+}$. HPLC2: $t_{\mathrm{R}} 12.2 \mathrm{~min}$, Purity $80 \%$.

2'-formyl-4'-methoxy-biphenyl-4-sulfonic acid 3,4,5-trimethoxy-benzylamide (2.8di). Using the above general procedure, 4-bromo-N-(3,4,5-trimethoxy-benzyl)benzenesulfonamide $(0.25 \mathrm{mmol}), 2$-formyl-4-methoxyphenylboronic acid $(0.30 \mathrm{mmol})$, sodium carbonate $(0.75 \mathrm{mmol})$, PS- $\mathrm{Pd}\left(\mathrm{Ph}_{3}\right)_{4}(0.025 \mathrm{mmol})$ and DME:EtOH: $\mathrm{H}_{2} \mathrm{O}(5 \mathrm{~mL})$ were used to synthesize 2.8di as a white solid $(90 \%)$. ${ }^{1} \mathrm{HNMR}\left(500 \mathrm{MHz}, \mathrm{CDCl}_{3}\right): \delta$ $3.78(\mathrm{~s}, 9 \mathrm{H}), 3.93(\mathrm{~s}, 3 \mathrm{H}), 4.15(\mathrm{~s}, 2 \mathrm{H}), 6.45(\mathrm{~s}, 2 \mathrm{H}), 7.24(\mathrm{~d}, 1 \mathrm{H}, J=8.5 \mathrm{~Hz}), 7.36(\mathrm{~d}, 1 \mathrm{H}$, $J=8.5 \mathrm{~Hz}), 7.48(\mathrm{~d}, 2 \mathrm{H}, J=8.5 \mathrm{~Hz}), 7.54(\mathrm{~s}, 1 \mathrm{H}), 7.94(\mathrm{~d}, 2 \mathrm{H}, J=8.0 \mathrm{~Hz}), 9.91(\mathrm{~s}, 1 \mathrm{H})$. MS(ESI): $\mathrm{m} / \mathrm{z}=494.6(\mathrm{M}+\mathrm{Na})^{+}$. HPLC2: $t_{\mathrm{R}} 13.2 \mathrm{~min}$, Purity $>99 \%$.

3'-fluoro-4'-methoxy-biphenyl-4-sulfonamide (2.8eb). Using the above general procedure, 4-bromo-N-(2-methoxymethyl-pyrrolidin-1-yl)-benzenesulfonamide $(0.25 \mathrm{mmol}), 3$-fluoro-4-methoxyphenylboronic acid $(0.30 \mathrm{mmol})$, sodium carbonate $(0.75 \mathrm{mmol}), \mathrm{PS}-\mathrm{Pd}\left(\mathrm{Ph}_{3}\right)_{4}(0.025 \mathrm{mmol})$ and DME:EtOH: $\mathrm{H}_{2} \mathrm{O}(5 \mathrm{~mL})$ were used to synthesize 2.8eb as a white solid (79\%). ${ }^{1} \mathrm{HNMR}(500 \mathrm{MHz}, \mathrm{MeOD}): \delta 3.94(\mathrm{~s}, 3 \mathrm{H})$, $7.19(\mathrm{t}, 1 \mathrm{H}, J=8.5 \mathrm{~Hz}), 7.42(\mathrm{~d}, 1 \mathrm{H}, J=3.5 \mathrm{~Hz}), 7.44(\mathrm{~s}, 1 \mathrm{H}), 7.67(\mathrm{~d}, 2 \mathrm{H}, J=8.0 \mathrm{~Hz})$, $7.73(\mathrm{~d}, 2 \mathrm{H}, J=8.0 \mathrm{~Hz}) . \mathrm{MS}(\mathrm{ESI}): \mathrm{m} / \mathrm{z}=280.8(\mathrm{M}-\mathrm{H})^{-}$. HPLC2: $t_{\mathrm{R}} 11.8 \mathrm{~min}$, Purity $83 \%$. 
4'-sulfamoyl-biphenyl-4-carboxylic acid (2.8ec). Using the above general procedure, bromo-N-(2-methoxymethyl-pyrrolidin-1-yl)-benzenesulfonamide $(0.25 \mathrm{mmol}), 5$ (dihydroxylboryl)-2-thiophenecarboxylic acid $(0.30 \mathrm{mmol})$, sodium carbonate $(0.75$ $\mathrm{mmol})$, PS- $\mathrm{Pd}\left(\mathrm{Ph}_{3}\right)_{4}(0.025 \mathrm{mmol})$ and DME:EtOH: $\mathrm{H}_{2} \mathrm{O}(5 \mathrm{~mL})$ were used to synthesize 2.8ec as a white solid (74\%). ${ }^{1} \mathrm{HNMR}\left(500 \mathrm{MHz}, \mathrm{CDCl}_{3}\right): \delta 7.66(\mathrm{~d}, 2 \mathrm{H}, J=8.5 \mathrm{~Hz})$, $7.74(\mathrm{~d}, 2 \mathrm{H}, J=8.5 \mathrm{~Hz}), 7.77(\mathrm{~d}, 2 \mathrm{H}, J=8.5 \mathrm{~Hz}), 8.05(\mathrm{~d}, 2 \mathrm{H}, J=8.5 \mathrm{~Hz}) . \quad \mathrm{MS}(\mathrm{ESI})$ : $\mathrm{m} / \mathrm{z}=277.0(\mathrm{M}+\mathrm{H})^{+}$. HPLC2: $t_{\mathrm{R}} 10.2 \mathrm{~min}$, Purity $85 \%$.

5-(4-sulfamoyl-phenyl)-thiophene-2-carboxylic acid (2.8ed). Using the above general procedure, bromo-N-(2-methoxymethyl-pyrrolidin-1-yl)-benzenesulfonamide (0.25 mmol), 5-(dihydroxylboryl)-2-thiophenecarboxylic acid $(0.30 \mathrm{mmol})$, sodium carbonate $(0.75 \mathrm{mmol}), \mathrm{PS}-\mathrm{Pd}\left(\mathrm{Ph}_{3}\right)_{4}(0.025 \mathrm{mmol})$ and DME:EtOH: $\mathrm{H}_{2} \mathrm{O}(5 \mathrm{~mL})$ were used to synthesize 2.8ed as a white solid (24\%). ${ }^{1} \mathrm{HNMR}(500 \mathrm{MHz}, \mathrm{MeOD}): \delta 7.31(\mathrm{~d}$, $1 \mathrm{H}, J=8.5 \mathrm{~Hz}), 7.51(\mathrm{~d}, 1 \mathrm{H}, J=8.5 \mathrm{~Hz}), 7.61(\mathrm{~d}, 2 \mathrm{H}, J=8.5 \mathrm{~Hz}), 7.75(\mathrm{~d}, 2 \mathrm{H}, J=8.5$ $\mathrm{Hz})$. MS(ESI): $\mathrm{m} / \mathrm{z}=284.1(\mathrm{M}+\mathrm{H})^{+}$. HPLC2: $t_{\mathrm{R}} 8.3 \mathrm{~min}$, Purity $80 \%$.

4-benzo[1,3]dioxol-5-yl-benzenesulfonamide (2.8ee). Using the above general procedure, bromo-N-(2-methoxymethyl-pyrrolidin-1-yl)-benzenesulfonamide ( $0.25 \mathrm{mmol}), 1,3$-benxodioxol-5-ylboronic acid $(0.30 \mathrm{mmol})$, sodium carbonate $(0.75$ mmol $), \mathrm{PS}-\mathrm{Pd}\left(\mathrm{Ph}_{3}\right)_{4}(0.025 \mathrm{mmol})$ and DME:EtOH: $\mathrm{H}_{2} \mathrm{O}(5 \mathrm{~mL})$ were used to synthesize 2.8ee as a white solid (63\%). ${ }^{1} \mathrm{HNMR}(500 \mathrm{MHz}, \mathrm{MeOD}): \delta 6.02(\mathrm{~s}, 2 \mathrm{H}), 6.92(\mathrm{~d}, 1 \mathrm{H}, J$ $=9.0 \mathrm{~Hz}), 7.16(\mathrm{~d}, 1 \mathrm{H}, J=5.5 \mathrm{~Hz}), 7.63(\mathrm{~d}, 2 \mathrm{H}, J=8.5 \mathrm{~Hz}), 7.77(\mathrm{~s}, 1 \mathrm{H}), 7.88(\mathrm{~d}, 2 \mathrm{H}, J$ $=8.5 \mathrm{~Hz}) . \mathrm{MS}(\mathrm{ESI}): \mathrm{m} / \mathrm{z}=276.9(\mathrm{M}-\mathrm{H})^{-}$. HPLC2: $t_{\mathrm{R}} 12.0 \mathrm{~min}$, Purity $92 \%$.

4-(2,4-dihydroxy-pyrimidin-5-yl)-benzenesulfonamide (2.8eg). Using the above general procedure, bromo-N-(2-methoxymethyl-pyrrolidin-1-yl)-benzenesulfonamide $(0.25 \mathrm{mmol}), 2,4$-dihydroxypyrimidine-5-boronic acid $(0.30 \mathrm{mmol})$, sodium carbonate $(0.75 \mathrm{mmol})$, PS- $\mathrm{Pd}\left(\mathrm{Ph}_{3}\right)_{4}(0.025 \mathrm{mmol})$ and DME:EtOH: $\mathrm{H}_{2} \mathrm{O}(5 \mathrm{~mL})$ were used to synthesize 2.8eg as a white solid (61\%). ${ }^{1} \mathrm{HNMR}(500 \mathrm{MHz}, \mathrm{MeOD}): \delta 6.22(\mathrm{~s}, 1 \mathrm{H})$, $6.28(\mathrm{~d}, 2 \mathrm{H}, J=8.5 \mathrm{~Hz}), 6.33(\mathrm{~d}, 2 \mathrm{H}, J=8.5 \mathrm{~Hz}) . \mathrm{MS}(\mathrm{ESI}): \mathrm{m} / \mathrm{z}=266.2(\mathrm{M}-\mathrm{H})^{-}$. HPLC2: $t_{\mathrm{R}} 10.1 \mathrm{~min}$, Purity $>99 \%$.

4-(5-formyl-furan-2-yl)-N-(2-methoxymethyl-pyrrolidin-1-yl)-benzenesulfonamide (2.8eh). Using the above general procedure, 4-bromo-N-(2-methoxymethyl-pyrrolidin-1yl)-benzenesulfonamide $(0.25 \mathrm{mmol}), 5$-formyl-2-furylboronic acid $(0.30 \mathrm{mmol})$, sodium carbonate $(0.75 \mathrm{mmol}), \mathrm{PS}-\mathrm{Pd}\left(\mathrm{Ph}_{3}\right)_{4}(0.025 \mathrm{mmol})$ and DME:EtOH: $\mathrm{H}_{2} \mathrm{O}(5 \mathrm{~mL})$ were used to synthesize 2.8eh as a light yellow solid (24\%). ${ }^{1} \mathrm{HNMR}(500 \mathrm{MHz}, \mathrm{MeOD}): \delta$ $1.60(\mathrm{~m}, 2 \mathrm{H}), 1.87(\mathrm{~m}, 2 \mathrm{H}), 3.27(\mathrm{~m}, 1 \mathrm{H}), 3.38(\mathrm{~s}, 3 \mathrm{H}), 3.43(\mathrm{~m}, 2 \mathrm{H}), 3.60(\mathrm{dd}, 1 \mathrm{H}, J=$ 4.0, $9.0 \mathrm{~Hz}), 3.79(\mathrm{~m}, 1 \mathrm{H}), 7.28(\mathrm{~d}, 1 \mathrm{H}, J=6.0 \mathrm{~Hz}), 7.56(\mathrm{~d}, 1 \mathrm{H}, J=5.5 \mathrm{~Hz}), 7.97(\mathrm{~d}, 2 \mathrm{H}$, $J=8.0 \mathrm{~Hz}), 8.11(\mathrm{~d}, 2 \mathrm{H}, J=8.5 \mathrm{~Hz}), 9.67(\mathrm{~s}, 1 \mathrm{H}) . \mathrm{MS}(\mathrm{ESI}): \mathrm{m} / \mathrm{z}=363.3(\mathrm{M}-\mathrm{H})^{-}$. HPLC2: $t_{\mathrm{R}} 12.7$ min, Purity $>99 \%$.

2'-formyl-4'-methoxy-biphenyl-4-sulfonic acid (2-methoxymethyl-pyrrolidin-1-yl)amide (2.9ei). Using the above general procedure, 4-bromo-N-(2-methoxymethylpyrrolidin-1-yl)-benzenesulfonamide $(0.25 \mathrm{mmol}), 2$-formyl-4-methoxyphenylboronic acid $(0.30 \mathrm{mmol})$, sodium carbonate $(0.75 \mathrm{mmol}), \mathrm{PS}-\mathrm{Pd}\left(\mathrm{Ph}_{3}\right)_{4}(0.025 \mathrm{mmol})$ and 
DME:EtOH: $\mathrm{H}_{2} \mathrm{O}(5 \mathrm{~mL})$ were used to synthesize $\mathbf{2 . 8 b i}$ as a white solid (92\%). ${ }^{1} \mathrm{HNMR}$ (500MHz, MeOD): $\delta 1.60(\mathrm{~m}, 2 \mathrm{H}), 1.86(\mathrm{~m}, 2 \mathrm{H}), 3.27(\mathrm{~m}, 1 \mathrm{H}), 3.39(\mathrm{~s}, 3 \mathrm{H}), 3.43(\mathrm{~m}$, $2 \mathrm{H}), 3.60(\mathrm{dd}, 1 \mathrm{H}, J=4.0,9.0 \mathrm{~Hz}), 3.79(\mathrm{~m}, 1 \mathrm{H}), 3.88(\mathrm{~s}, 3 \mathrm{H}), 6.97(\mathrm{~d}, 1 \mathrm{H}, J=8.0 \mathrm{~Hz})$, $7.19(\mathrm{~d}, 1 \mathrm{H}, J=8.0 \mathrm{~Hz}), 7.24(\mathrm{~d}, 1 \mathrm{H}, J=8.0 \mathrm{~Hz}), 7.61(\mathrm{~d}, 2 \mathrm{H}, J=8.5 \mathrm{~Hz}), 7.491(\mathrm{~d}, 2 \mathrm{H}$, $J=8.0 \mathrm{~Hz})$. .MS(ESI): $\mathrm{m} / \mathrm{z}=403.2(\mathrm{M}-\mathrm{H})^{-}$. HPLC2: $t_{\mathrm{R}} 12.7 \mathrm{~min}$, Purity $>99 \%$.

3'-fluoro-4'-methoxy-biphenyl-4-sulfonic acid (2-piperidin-1-yl-ethyl)-amide (2.8fb). Using the above general procedure, 4-bromo-N-(2-piperidin-1-yl-ethyl)benzenesulfonamide $(0.25 \mathrm{mmol})$, 3-fluoro-4-methoxyphenylboronic acid $(0.30 \mathrm{mmol})$, sodium carbonate $(0.75 \mathrm{mmol}), \mathrm{PS}-\mathrm{Pd}\left(\mathrm{Ph}_{3}\right)_{4}(0.025 \mathrm{mmol})$ and DME:EtOH: $\mathrm{H}_{2} \mathrm{O}(5 \mathrm{~mL})$ were used to synthesize $\mathbf{2 . 8 f b}$ as a white solid (23\%). ${ }^{1} \mathrm{HNMR}(500 \mathrm{MHz}, \mathrm{MeOD}): \delta$ 1.57 (bt, 1H, J = 12.0 Hz), 1.85 (m, 3H), 1.98 (bd, 4H, J = $15.0 \mathrm{~Hz}), 3.01$ (t, 2H, J = 12.0 $\mathrm{Hz}), 3.27(\mathrm{~m}, 4 \mathrm{H}), 3.62(\mathrm{bd}, 2 \mathrm{H}, J=12.5 \mathrm{~Hz}), 3.96(\mathrm{~s}, 3 \mathrm{H}), 7.25$ (t, 1H, J = 8.5 Hz), 7.51 $(\mathrm{s}, 1 \mathrm{H}), 7.53(\mathrm{t}, 1 \mathrm{H}, \mathrm{J}=3.5 \mathrm{~Hz}), 7.86(\mathrm{~d}, 2 \mathrm{H}, J=8.5 \mathrm{~Hz}), 7.95(\mathrm{~d}, 2 \mathrm{H}, J=8.5 \mathrm{~Hz})$. MS(ESI): $\mathrm{m} / \mathrm{z}=393.2(\mathrm{M}+\mathrm{H})^{+}$. HPLC2: $t_{\mathrm{R}} 12.7 \mathrm{~min}$, Purity $>99 \%$.

4'-(2-piperidin-1-yl-ethylsulfamoyl)-biphenyl-4-carboxylic acid (2.8fc). Using the above general procedure, 4-bromo-N-(2-piperidin-1-yl-ethyl)-benzenesulfonamide $(0.25 \mathrm{mmol}), 4$-carboxylphenylboronic acid $(0.30 \mathrm{mmol})$, sodium carbonate $(0.75 \mathrm{mmol})$, PS- $\mathrm{Pd}\left(\mathrm{Ph}_{3}\right)_{4}(0.025 \mathrm{mmol})$ and DME:EtOH:H $\mathrm{H}_{2} \mathrm{O}(5 \mathrm{~mL})$ were used to synthesize $\mathbf{2 . 8 f c}$ as a white solid (67\%). ${ }^{1} \mathrm{HNMR}(500 \mathrm{MHz}, \mathrm{MeOD}): \delta 1.57$ (bt, $\left.1 \mathrm{H}, \mathrm{J}=13.5 \mathrm{~Hz}\right), 1.86(\mathrm{~m}$, $3 \mathrm{H}), 1.99(\mathrm{bd}, 4 \mathrm{H}, \mathrm{J}=14.5 \mathrm{~Hz}), 3.02(\mathrm{t}, 2 \mathrm{H}, \mathrm{J}=14.5 \mathrm{~Hz}), 3.28(\mathrm{bs}, 4 \mathrm{H}), 3.63(\mathrm{bd}, 2 \mathrm{H}, J=$ $12.0 \mathrm{~Hz}), 7.84(\mathrm{~d}, 2 \mathrm{H}, \mathrm{J}=8.0 \mathrm{~Hz}), 7.96(\mathrm{~d}, 2 \mathrm{H}, \mathrm{J}=8.5 \mathrm{~Hz}), 8.02(\mathrm{~d}, 2 \mathrm{H}, J=8.5 \mathrm{~Hz}), 8.18$ $(\mathrm{d}, 2 \mathrm{H}, J=8.5 \mathrm{~Hz})$. MS(ESI): $\mathrm{m} / \mathrm{z}=389.1(\mathrm{M}+\mathrm{H})^{+}$. HPLC2: $t_{\mathrm{R}} 11.3 \mathrm{~min}$, Purity $>99 \%$.

\section{4-benzo[1,3]dioxol-5-yl-N-(2-piperidin-1-yl-ethyl)-benzenesulfonamide (2.8fe).}

Using the above general procedure, 4-bromo-N-(2-piperidin-1-yl-ethyl)-

benzenesulfonamide $(0.25 \mathrm{mmol}), 1,3$-benxodioxol-5-ylboronic acid $(0.30 \mathrm{mmol})$, sodium carbonate $(0.75 \mathrm{mmol}), \mathrm{PS}-\mathrm{Pd}\left(\mathrm{Ph}_{3}\right)_{4}(0.025 \mathrm{mmol})$ and DME:EtOH: $\mathrm{H}_{2} \mathrm{O}(5 \mathrm{~mL})$ were used to synthesize 2.8fe as a white solid (34\%). ${ }^{1} \mathrm{HNMR}(500 \mathrm{MHz}, \mathrm{MeOD}): \delta 1.57$ (bt, $1 \mathrm{H}, \mathrm{J}=13.5 \mathrm{~Hz}), 1.85(\mathrm{~m}, 3 \mathrm{H}), 1.98(\mathrm{bd}, 4 \mathrm{H}, \mathrm{J}=14.5 \mathrm{~Hz}), 3.01$ (t, 2H, J = $12.5 \mathrm{~Hz}), 3.27$ $(\mathrm{m}, 4 \mathrm{H}), 3.61(\mathrm{bd}, 2 \mathrm{H}, J=11.5 \mathrm{~Hz}), 6.05(\mathrm{~s}, 2 \mathrm{H}), 6.97(\mathrm{~d}, 1 \mathrm{H}, \mathrm{J}=8.5 \mathrm{~Hz}), 7.22(\mathrm{~m}, 2 \mathrm{H}$, $7.81(\mathrm{~d}, 2 \mathrm{H}, J=8.5 \mathrm{~Hz}), 7.93(\mathrm{~d}, 2 \mathrm{H}, J=8.5 \mathrm{~Hz}) . \mathrm{MS}(\mathrm{ESI}): \mathrm{m} / \mathrm{z}=389.1(\mathrm{M}+\mathrm{H})^{+}$. HPLC2: $t_{\mathrm{R}} 12.7 \mathrm{~min}$, Purity $89 \%$.

4-(3,5-dimethyl-isoxazol-4-yl)-N-(2-piperidin-1-yl-ethyl)-benzenesulfonamide (2.8ff). Using the above general procedure, 4-bromo-N-(2-piperidin-1-yl-ethyl)benzenesulfonamide $(0.25 \mathrm{mmol}), 3,5$-dimethyl-4-isoxazolylboronic acid $(0.30 \mathrm{mmol})$, sodium carbonate $(0.75 \mathrm{mmol}), \mathrm{PS}-\mathrm{Pd}\left(\mathrm{Ph}_{3}\right)_{4}(0.025 \mathrm{mmol})$ and DME:EtOH: $\mathrm{H}_{2} \mathrm{O}(5 \mathrm{~mL})$ were used to synthesize 2.8ff as a light yellow solid (66\%). ${ }^{1} \mathrm{HNMR}(500 \mathrm{MHz}, \mathrm{MeOD})$ : $\delta 1.57(\mathrm{bt}, 1 \mathrm{H}, \mathrm{J}=12.5 \mathrm{~Hz}), 1.86(\mathrm{~m}, 3 \mathrm{H}), 1.99(\mathrm{bd}, 4 \mathrm{H}, \mathrm{J}=15.0 \mathrm{~Hz}), 2.31(\mathrm{~s}, 3 \mathrm{H}), 2.48$ $(\mathrm{s}, 3 \mathrm{H}), 3.02(\mathrm{t}, 2 \mathrm{H}, \mathrm{J}=12.5 \mathrm{~Hz}), 3.29(\mathrm{bs}, 4 \mathrm{H}), 3.63(\mathrm{bd}, 2 \mathrm{H}, J=11.0 \mathrm{~Hz}), 7.64(\mathrm{~d}, 2 \mathrm{H}, J$ $=8.5 \mathrm{~Hz}), 8.01(\mathrm{~d}, 2 \mathrm{H}, J=8.5 \mathrm{~Hz}) . \mathrm{MS}(\mathrm{ESI}): \mathrm{m} / \mathrm{z}=364.1(\mathrm{M}+\mathrm{H})^{+}$. HPLC2: $t_{\mathrm{R}} 11.3$ min, Purity $91 \%$. 
4-(2,4-dihydroxy-pyrimidin-5-yl)-N-(2-piperidin-1-yl-ethyl)-benzenesulfonamide (2.8fg). Using the above general procedure, 4-bromo-N-(2-piperidin-1-yl-ethyl)benzenesulfonamide $(0.25 \mathrm{mmol})$, 2,4-dihydroxypyrimidine-5-boronic acid $(0.30 \mathrm{mmol})$, sodium carbonate $(0.75 \mathrm{mmol}), \mathrm{PS}-\mathrm{Pd}\left(\mathrm{Ph}_{3}\right)_{4}(0.025 \mathrm{mmol})$ and DME:EtOH: $\mathrm{H}_{2} \mathrm{O}(5 \mathrm{~mL})$ were used to synthesize $\mathbf{2 . 8 f g}$ as a light yellow solid (74\%). ${ }^{1} \mathrm{HNMR}(500 \mathrm{MHz}, \mathrm{MeOD})$ : $\delta 1.57(\mathrm{bt}, 1 \mathrm{H}, \mathrm{J}=11.5 \mathrm{~Hz}), 1.85(\mathrm{~m}, 3 \mathrm{H}), 1.98(\mathrm{bd}, 4 \mathrm{H}, \mathrm{J}=16.0 \mathrm{~Hz}), 3.01(\mathrm{t}, 2 \mathrm{H}, \mathrm{J}=$ $12.5 \mathrm{~Hz}), 3.25(\mathrm{~m}, 4 \mathrm{H}), 3.61(\mathrm{bd}, 2 \mathrm{H}, J=11.5 \mathrm{~Hz}), 7.76(\mathrm{~s}, 1 \mathrm{H}), 7.83(\mathrm{~d}, 2 \mathrm{H}, J=8.5 \mathrm{~Hz})$, $7.91(\mathrm{~d}, 2 \mathrm{H}, J=9.0 \mathrm{~Hz}) . \mathrm{MS}(\mathrm{ESI}): \mathrm{m} / \mathrm{z}=379.1(\mathrm{M}+\mathrm{H})^{+}$. HPLC2: $t_{\mathrm{R}} 8.9 \mathrm{~min}$, Purity $>$ $99 \%$.

4-(5-formyl-furan-2-yl)-N-(2-piperidin-1-yl-ethyl)-benzenesulfonamide (2.8fh). Using the above general procedure, 4-bromo-N-(2-piperidin-1-yl-ethyl)benzenesulfonamide $(0.25 \mathrm{mmol})$, 5-formyl-2-furylboronic acid $(0.30 \mathrm{mmol})$, sodium carbonate $(0.75 \mathrm{mmol}), \mathrm{PS}-\mathrm{Pd}\left(\mathrm{Ph}_{3}\right)_{4}(0.025 \mathrm{mmol})$ and DME:EtOH: $\mathrm{H}_{2} \mathrm{O}(5 \mathrm{~mL})$ were used to synthesize 2.8fh as a light yellow solid (69\%). ${ }^{1} \mathrm{HNMR}(500 \mathrm{MHz}, \mathrm{MeOD}): \delta$ 1.57 (bt, $1 \mathrm{H}, \mathrm{J}=12.0 \mathrm{~Hz}$ ), 1.85 (m, 3H), 1.98 (bd, 4H, J = 17.5 Hz), 3.01 (t, 2H, J = 12.0 $\mathrm{Hz}$ ), 3.26 (bs, 4H), 3.62 (bd, 2H, J=12.0 Hz), 6.59 (d, 1H, J = 4.0 Hz), 7.06 (d, 1H, J = $3.0 \mathrm{~Hz}), 7.93(\mathrm{~d}, 2 \mathrm{H}, J=8.5 \mathrm{~Hz}), 7.96(\mathrm{~d}, 2 \mathrm{H}, J=8.5 \mathrm{~Hz}) . \mathrm{MS}(\mathrm{ESI}): \mathrm{m} / \mathrm{z}=363.1$ $(\mathrm{M}+\mathrm{H})^{+}$. HPLC2: $t_{\mathrm{R}} 12.2 \mathrm{~min}$, Purity $>99 \%$.

2'-formyl-4'-methoxy-biphenyl-4-sulfonic acid (2-piperidin-1-yl-ethyl)-amide (2.8fi). Using the above general procedure, 4-bromo-N-(2-piperidin-1-yl-ethyl)benzenesulfonamide $(0.25 \mathrm{mmol}), 2$-formyl-4-methoxyphenylboronic acid $(0.30 \mathrm{mmol})$, sodium carbonate $(0.75 \mathrm{mmol}), \mathrm{PS}-\mathrm{Pd}\left(\mathrm{Ph}_{3}\right)_{4}(0.025 \mathrm{mmol})$ and DME:EtOH: $\mathrm{H}_{2} \mathrm{O}(5 \mathrm{~mL})$ were used to synthesize 2.8fi as a white solid (31\%). ${ }^{1} \mathrm{HNMR}(500 \mathrm{MHz}, \mathrm{MeOD}): \delta$ 1.58 (bt, 1H, J = 11.5 Hz), $1.86(\mathrm{~m}, 3 \mathrm{H}), 1.99$ (bd, 4H, J = 16.0 Hz), 3.02 (t, 2H, J = 13.5 $\mathrm{Hz}), 3.30(\mathrm{bs}, 4 \mathrm{H}), 3.63(\mathrm{bd}, 2 \mathrm{H}, J=11.5 \mathrm{~Hz}), 3.94(\mathrm{~s}, 3 \mathrm{H}), 7.35$ (d, 1H, J = 8.5 Hz), 7.47 $(\mathrm{d}, 1 \mathrm{H}, \mathrm{J}=8.5 \mathrm{~Hz}), 7.56(\mathrm{~s}, 1 \mathrm{H}) 7.66(\mathrm{~d}, 2 \mathrm{H}, J=8.5 \mathrm{~Hz}), 8.01(\mathrm{~d}, 2 \mathrm{H}, J=8.5 \mathrm{~Hz}), 9.92$ (s, 1H). MS(ESI): $\mathrm{m} / \mathrm{z}=403.2(\mathrm{M}+\mathrm{H})^{+}$. HPLC2: $t_{\mathrm{R}} 12.4 \mathrm{~min}$, Purity $95 \%$.

3'-fluoro-4'-methoxy-biphenyl-4-sulfonic acid (furan-2-ylmethyl)-amide (2.8gb). Using the above general procedure, 4-bromo-N-furan-2-ylmethyl-benzenesulfonamide $(0.25 \mathrm{mmol}), 3$-fluoro-4-methoxyphenylboronic acid $(0.30 \mathrm{mmol})$, sodium carbonate $(0.75$ mmol), PS- $\mathrm{Pd}\left(\mathrm{Ph}_{3}\right)_{4}(0.025 \mathrm{mmol})$ and DME:EtOH: $\mathrm{H}_{2} \mathrm{O}(5 \mathrm{~mL})$ were used to synthesize 2.8gb as a white solid (98\%). ${ }^{1} \mathrm{HNMR}(500 \mathrm{MHz}, \mathrm{DMSO}): \delta 3.91(\mathrm{~s}, 3 \mathrm{H}), 4.20(\mathrm{~s}, 2 \mathrm{H})$, $6.18(\mathrm{~s}, 1 \mathrm{H}), 6.31(\mathrm{t}, 1 \mathrm{H}, J=2.5 \mathrm{~Hz}), 7.30(\mathrm{t}, 1 \mathrm{H}, J=8.5 \mathrm{~Hz}), 7.49,(\mathrm{~s}, 1 \mathrm{H}), 7.57(\mathrm{~d}, 1 \mathrm{H}, J$ $=9.0 \mathrm{~Hz}), 7.67(\mathrm{~d}, 1 \mathrm{H}, J=13.0 \mathrm{~Hz}), 7.79(\mathrm{~d}, 2 \mathrm{H}, J=8.5 \mathrm{~Hz}), 7.84(\mathrm{~d}, 2 \mathrm{H}, J=8.5 \mathrm{~Hz})$. MS(ESI): $\mathrm{m} / \mathrm{z}=384.3(\mathrm{M}+\mathrm{Na})^{+}$. HPLC2: $t_{\mathrm{R}} 13.5 \mathrm{~min}$, Purity $98 \%$.

4'-[(furan-2-ylmethyl)-sulfamoyl]-biphenyl-4-carboxylic acid (2.8gc). Using the above general procedure, 4-bromo-N-furan-2-ylmethyl-benzenesulfonamide $(0.25 \mathrm{mmol})$, $(0.30 \mathrm{mmol})$, sodium carbonate $(0.75 \mathrm{mmol}), \mathrm{PS}-\mathrm{Pd}\left(\mathrm{Ph}_{3}\right)_{4}(0.025 \mathrm{mmol})$ and

DME:EtOH: $\mathrm{H}_{2} \mathrm{O}(5 \mathrm{~mL})$ were used to synthesize $\mathbf{2 . 8 g c}$ as a white solid (91\%). ${ }^{1} \mathrm{HNMR}$ (300MHz, MeOD): $\delta 4.16(\mathrm{~s}, 2 \mathrm{H}), 6.12(\mathrm{~s}, 1 \mathrm{H}), 6.22(\mathrm{~s}, 1 \mathrm{H}), 7.28(\mathrm{~s}, 1 \mathrm{H}), 7.83$ (t, 4H, $J$ $=13.5 \mathrm{~Hz}), 7.91(\mathrm{~d}, 2 \mathrm{H}, J=14.5 \mathrm{~Hz}), 8.15(\mathrm{~d}, 2 \mathrm{H}, J=14.0 \mathrm{~Hz}) . \mathrm{MS}(\mathrm{ESI}): \mathrm{m} / \mathrm{z}=381.1$ $(\mathrm{M}+\mathrm{Na})^{+}$. HPLC2: $t_{\mathrm{R}} 12.3$ min, Purity $>99 \%$. 
5-\{4-[(furan-2-ylmethyl)-sulfamoyl]-phenyl\}-thiophene-2-carboxylic acid (2.8gd). Using the above general procedure, 4-bromo-N-furan-2-ylmethyl-benzenesulfonamide (0.25 mmol), 5-(dihydroxylboryl)-2-thiophenecarboxylic acid $(0.30 \mathrm{mmol})$, sodium carbonate $(0.75 \mathrm{mmol})$, PS- $\mathrm{Pd}\left(\mathrm{Ph}_{3}\right)_{4}(0.025 \mathrm{mmol})$ and DME:EtOH: $\mathrm{H}_{2} \mathrm{O}(5 \mathrm{~mL})$ were used to synthesize 2.8gd as a light yellow solid (34\%). ${ }^{1} \mathrm{HNMR}(300 \mathrm{MHz}, \mathrm{MeOD}): \delta$ 4.15 (s, 2H), $6.11(\mathrm{~s}, 1 \mathrm{H}), 6.21(\mathrm{~s}, 1 \mathrm{H}), 7.27(\mathrm{~s}, 1 \mathrm{H}), 7.57$ (d, 1H, $J=6.5 \mathrm{~Hz}), 7.78$ (d, 1H, $J=6.5 \mathrm{~Hz}), 7.84$ (bs, $4 \mathrm{H}) . \mathrm{MS}(\mathrm{ESI}): \mathrm{m} / \mathrm{z}=386.0(\mathrm{M}+\mathrm{Na})^{+}$. HPLC2: $t_{\mathrm{R}} 12.3$ min, Purity $94 \%$.

4-benzo[1,3] dioxol-5-yl-N-furan-2-ylmethyl-benzenesulfonamide (2.8ge). Using the above general procedure, 4-bromo- $\mathrm{N}$-furan-2-ylmethyl-benzenesulfonamide $(0.25 \mathrm{mmol})$, 1,3-benxodioxol-5-ylboronic acid $(0.30 \mathrm{mmol})$, sodium carbonate $(0.75 \mathrm{mmol})$, PS$\mathrm{Pd}\left(\mathrm{Ph}_{3}\right)_{4}(0.025 \mathrm{mmol})$ and DME:EtOH: $\mathrm{H}_{2} \mathrm{O}(5 \mathrm{~mL})$ were used to synthesize 2.8ge as a white solid (92\%). ${ }^{1} \mathrm{HNMR}(500 \mathrm{MHz}, \mathrm{DMSO}): \delta 4.02(\mathrm{~s}, 2 \mathrm{H}), 6.10(\mathrm{~s}, 2 \mathrm{H}), 6.19(\mathrm{~d}$, $1 \mathrm{H}, J=3.5 \mathrm{~Hz}), 6.31(\mathrm{t}, 1 \mathrm{H}, J=2.5 \mathrm{~Hz}), 7.05$, (d, $1 \mathrm{H}, J=8.5 \mathrm{~Hz}), 7.24(\mathrm{~d}, 1 \mathrm{H}, J=8.5$ $\mathrm{Hz}), 7.35$ (d, $1 \mathrm{H}, J=2.0 \mathrm{~Hz}$ ), 7.50 (s, $1 \mathrm{H}), 7.89$ (bs, 4H). $\mathrm{MS}(\mathrm{ESI}): \mathrm{m} / \mathrm{z}=380.1$ $(\mathrm{M}+\mathrm{Na})^{+}$. HPLC2: $t_{\mathrm{R}} 13.4 \mathrm{~min}$, Purity $96 \%$.

4-(2,4-dihydroxy-pyrimidin-5-yl)-N-furan-2-ylmethyl-benzenesulfonamide (2.8gg). Using the above general procedure, 4-bromo-N-furan-2-ylmethyl-benzenesulfonamide $(0.25 \mathrm{mmol}), 2,4$-dihydroxypyrimidine- 5 -boronic acid $(0.30 \mathrm{mmol})$, sodium carbonate $(0.75 \mathrm{mmol})$, PS- $\mathrm{Pd}\left(\mathrm{Ph}_{3}\right)_{4}(0.025 \mathrm{mmol})$ and DME:EtOH: $\mathrm{H}_{2} \mathrm{O}(5 \mathrm{~mL})$ were used to synthesize 2.8gg as a white solid (93\%). ${ }^{1} \mathrm{HNMR}(500 \mathrm{MHz}, \mathrm{MeOD}): \delta 4.18(\mathrm{~s}, 2 \mathrm{H})$, $6.13(\mathrm{~d}, 1 \mathrm{H}, J=3.0 \mathrm{~Hz}), 6.24(\mathrm{t}, 1 \mathrm{H}, J=3.0 \mathrm{~Hz}), 7.31(\mathrm{~s}, 1 \mathrm{H}), 7.73$ (d, $3 \mathrm{H}, J=9.0 \mathrm{~Hz})$, $7.82(\mathrm{~d}, 2 \mathrm{H}, J=8.5 \mathrm{~Hz}) . \mathrm{MS}(\mathrm{ESI}): \mathrm{m} / \mathrm{z}=370.0(\mathrm{M}+\mathrm{Na})^{+}$. HPLC2: $t_{\mathrm{R}} 9.8 \mathrm{~min}$, Purity > $99 \%$.

4-(5-formyl-furan-2-yl)-N-furan-2-ylmethyl-benzenesulfonamide (2.8gh). Using the above general procedure, 4-bromo-N-furan-2-ylmethyl-benzenesulfonamide $(0.25 \mathrm{mmol})$, 5 -formyl-2-furylboronic acid $(0.30 \mathrm{mmol})$, sodium carbonate $(0.75 \mathrm{mmol}), \mathrm{PS}-\mathrm{Pd}\left(\mathrm{Ph}_{3}\right)_{4}$ $(0.025 \mathrm{mmol})$ and DME:EtOH: $\mathrm{H}_{2} \mathrm{O}(5 \mathrm{~mL})$ were used to synthesize $\mathbf{2 . 8 g h}$ as a light yeallow solid (52\%). ${ }^{1} \mathrm{HNMR}(300 \mathrm{MHz}, \mathrm{MeOD}): \delta 4.17(\mathrm{~s}, 2 \mathrm{H}), 6.11(\mathrm{~d}, 1 \mathrm{H}, J=6.5$ $\mathrm{Hz}), 6.20(\mathrm{t}, 1 \mathrm{H}, J=4.5 \mathrm{~Hz}), 7.26(\mathrm{~d}, 2 \mathrm{H}, J=6.5 \mathrm{~Hz}), 7.56,(\mathrm{~d}, 1 \mathrm{H}, J=6.5 \mathrm{~Hz}), 7.89(\mathrm{~d}$, $2 \mathrm{H}, J=11.5 \mathrm{~Hz}), 8.01(\mathrm{~d}, 2 \mathrm{H}, J=14.5 \mathrm{~Hz}) . \mathrm{MS}(\mathrm{ESI}): \mathrm{m} / \mathrm{z}=332.0(\mathrm{M}+\mathrm{H})^{+}$. HPLC2: $t_{\mathrm{R}}$ 13.0 min, Purity $86 \%$.

2'-formyl-4'-methoxy-biphenyl-4-sulfonic acid (furan-2-ylmethyl)-amide (2.8gi). Using the above general procedure, 4-bromo-N-furan-2-ylmethyl-benzenesulfonamide $(0.25 \mathrm{mmol}), 2$-formyl-4-methoxyphenylboronic acid $(0.30 \mathrm{mmol})$, sodium carbonate $(0.75 \mathrm{mmol}), \mathrm{PS}-\mathrm{Pd}\left(\mathrm{Ph}_{3}\right)_{4}(0.025 \mathrm{mmol})$ and DME:EtOH: $\mathrm{H}_{2} \mathrm{O}(5 \mathrm{~mL})$ were used to synthesize 2.8gi as a white solid (92\%). ${ }^{1} \mathrm{HNMR}(500 \mathrm{MHz}, \mathrm{MeOD}): \delta 3.94(\mathrm{~s}, 3 \mathrm{H})$, $4.21(\mathrm{~s}, 2 \mathrm{H}), 6.11(\mathrm{~d}, 1 \mathrm{H}, J=3.0 \mathrm{~Hz}), 6.22(\mathrm{t}, 1 \mathrm{H}, J=2.5 \mathrm{~Hz}), 7.30(\mathrm{~s}, 1 \mathrm{H}), 7.33(\mathrm{~d}, 1 \mathrm{H}, J$ $=8.5 \mathrm{~Hz}), 7.45,(\mathrm{~d}, 1 \mathrm{H}, J=8.5 \mathrm{~Hz}), 7.52(\mathrm{~d}, 2 \mathrm{H}, J=8.5 \mathrm{~Hz}), 7.54(\mathrm{~d}, 1 \mathrm{H}, J=3.0 \mathrm{~Hz})$, $7.89(\mathrm{~d}, 2 \mathrm{H}, J=8.5 \mathrm{~Hz}), 9.88(\mathrm{~s}, 1 \mathrm{H}) . \mathrm{MS}(\mathrm{ESI}): \mathrm{m} / \mathrm{z}=394.4(\mathrm{M}+\mathrm{Na})^{+}$. HPLC2: $t_{\mathrm{R}} 13.1$ min, Purity $96 \%$. 
3'-fluoro-4'-methoxy-biphenyl-4-sulfonic acid [3-(2-oxo-pyrrolidin-1-yl)-propyl]amide (2.8hb). Using the above general procedure, 4-bromo-N-[3-(2-oxo-pyrrolidin-1yl)-propyl]-benzenesulfonamide $(0.25 \mathrm{mmol})$, 3-fluoro-4-methoxyphenylboronic acid $(0.30 \mathrm{mmol})$, sodium carbonate $(0.75 \mathrm{mmol}), \mathrm{PS}-\mathrm{Pd}\left(\mathrm{Ph}_{3}\right)_{4}(0.025 \mathrm{mmol})$ and DME:EtOH: $\mathrm{H}_{2} \mathrm{O}(5 \mathrm{~mL})$ were used to synthesize $\mathbf{2 . 8 h b}$ as a white solid (84\%). ${ }^{1} \mathrm{HNMR}$ (500MHz, DMSO): $\delta 1.57(\mathrm{~m}, 2 \mathrm{H}), 1.86(\mathrm{~m}, 2 \mathrm{H}), 2.16(\mathrm{t}, 2 \mathrm{H}, J=8.0 \mathrm{~Hz}), 2.72(\mathrm{t}, 2 \mathrm{H}, J$ $=7.0 \mathrm{~Hz}), 3.14(\mathrm{~m}, 2 \mathrm{H}), 3.23(\mathrm{t}, 2 \mathrm{H}, J=7.0 \mathrm{~Hz}), 3.90(\mathrm{~s}, 3 \mathrm{H}), 7.30(\mathrm{~d}, 1 \mathrm{H}, J=9.0 \mathrm{~Hz})$, $7.58(\mathrm{~d}, 1 \mathrm{H}, J=8.5 \mathrm{~Hz}), 7.68(\mathrm{~d}, 1 \mathrm{H}, J=12.0 \mathrm{~Hz}), 7.82(\mathrm{~d}, 2 \mathrm{H}, J=6.0 \mathrm{~Hz}), 7.89(\mathrm{~d}, 2 \mathrm{H}$, $J=4.5 \mathrm{~Hz})$. MS(ESI): $\mathrm{m} / \mathrm{z}=429.6(\mathrm{M}+\mathrm{Na})^{+}$. HPLC2: $t_{\mathrm{R}} 13.0 \mathrm{~min}$, Purity $93 \%$.

4'-[3-(2-oxo-pyrrolidin-1-yl)-propylsulfamoyl]-biphenyl-4-carboxylic acid (2.8hc). Using the above general procedure, 4-bromo-N-[3-(2-oxo-pyrrolidin-1-yl)-propyl]benzenesulfonamide $(0.25 \mathrm{mmol})$, 4-carboxylphenylboronic acid $(0.30 \mathrm{mmol})$, sodium carbonate $(0.75 \mathrm{mmol})$, PS- $\mathrm{Pd}\left(\mathrm{Ph}_{3}\right)_{4}(0.025 \mathrm{mmol})$ and DME:EtOH: $\mathrm{H}_{2} \mathrm{O}(5 \mathrm{~mL})$ were used to synthesize $\mathbf{2 . 8 h c}$ as a white solid (72\%). ${ }^{1} \mathrm{HNMR}(500 \mathrm{MHz}, \mathrm{MeOD}): \delta 1.74(\mathrm{~m}$, $2 \mathrm{H}), 2.03(\mathrm{~m}, 2 \mathrm{H}), 2.36(\mathrm{t}, 2 \mathrm{H}, J=8.0 \mathrm{~Hz}), 2.91(\mathrm{t}, 2 \mathrm{H}, J=7.0 \mathrm{~Hz}), 3.33(\mathrm{~m}, 2 \mathrm{H}), 3.43(\mathrm{t}$, $2 \mathrm{H}, J=7.5 \mathrm{~Hz}), 7.83(\mathrm{~d}, 2 \mathrm{H}, J=6.0 \mathrm{~Hz}), 7.92(\mathrm{~d}, 2 \mathrm{H}, J=4.0 \mathrm{~Hz}), 7.98(\mathrm{~d}, 2 \mathrm{H}, J=4.0$ $\mathrm{Hz}), 8.17(\mathrm{~d}, 2 \mathrm{H}, J=4.0 \mathrm{~Hz}) . \mathrm{MS}(\mathrm{ESI}): \mathrm{m} / \mathrm{z}=403.5(\mathrm{M}+\mathrm{H})^{+}$. HPLC2: $t_{\mathrm{R}} 11.6 \mathrm{~min}$, Purity $85 \%$.

\section{4-benzo[1,3]dioxol-5-yl-N-[3-(2-oxo-pyrrolidin-1-yl)-propyl]-benzenesulfonamide} (2.8he). Using the above general procedure, 4-bromo-N-[3-(2-oxo-pyrrolidin-1-yl)propyl]-benzenesulfonamide $(0.25 \mathrm{mmol}), 1,3$-benxodioxol-5-ylboronic acid $(0.30 \mathrm{mmol})$, sodium carbonate $(0.75 \mathrm{mmol}), \mathrm{PS}-\mathrm{Pd}\left(\mathrm{Ph}_{3}\right)_{4}(0.025 \mathrm{mmol})$ and DME:EtOH: $\mathrm{H}_{2} \mathrm{O}(5 \mathrm{~mL})$ were used to synthesize 2.8he as a light yellow solid (97\%). ${ }^{1} \mathrm{HNMR}(500 \mathrm{MHz}, \mathrm{DMSO})$ : $\delta 1.57(\mathrm{~m}, 2 \mathrm{H}), 1.85(\mathrm{~m}, 2 \mathrm{H}), 2.16(\mathrm{t}, 2 \mathrm{H}, J=8.0 \mathrm{~Hz}), 2.71(\mathrm{t}, 2 \mathrm{H}, J=7.0 \mathrm{~Hz}), 3.13(\mathrm{~m}$, $2 \mathrm{H}), 3.23(\mathrm{t}, 2 \mathrm{H}, J=7.0 \mathrm{~Hz}), 6.09(\mathrm{~s}, 2 \mathrm{H}), 7.04(\mathrm{~d}, 1 \mathrm{H}, J=8.0 \mathrm{~Hz}), 7.24(\mathrm{~d}, 1 \mathrm{H}, J=8.0$ $\mathrm{Hz}), 7.35(\mathrm{~s}, 1 \mathrm{H}), 7.80(\mathrm{~d}, 2 \mathrm{H}, J=9.0 \mathrm{~Hz}), 7.84(\mathrm{~d}, 2 \mathrm{H}, J=9.0 \mathrm{~Hz}) . \mathrm{MS}(\mathrm{ESI}): \mathrm{m} / \mathrm{z}=$ $425.6(\mathrm{M}+\mathrm{Na})^{+}$. HPLC2: $t_{\mathrm{R}} 12.8 \mathrm{~min}$, Purity $97 \%$.

\section{4-(3,5-dimethyl-isoxazol-4-yl)-N-[3-(2-oxo-pyrrolidin-1-yl)-propyl]-}

benzenesulfonamide (2.8hf). Using the above general procedure, 4-bromo-N-[3-(2-oxopyrrolidin-1-yl)-propyl]-benzenesulfonamide $(0.25 \mathrm{mmol}), 3,5$-dimethyl-4isoxazolylboronic acid $(0.30 \mathrm{mmol})$, sodium carbonate $(0.75 \mathrm{mmol}), \mathrm{PS}-\mathrm{Pd}\left(\mathrm{Ph}_{3}\right)_{4}(0.025$ $\mathrm{mmol}$ ) and DME:EtOH: $\mathrm{H}_{2} \mathrm{O}(5 \mathrm{~mL})$ were used to synthesize $\mathbf{2 . 8 h f}$ as a light yellow solid (53\%). ${ }^{1} \mathrm{HNMR}(500 \mathrm{MHz}, \mathrm{MeOD}): \delta 1.75(\mathrm{~m}, 2 \mathrm{H}), 2.04(\mathrm{~m}, 2 \mathrm{H}), 2.31(\mathrm{~s}, 3 \mathrm{H}), 2.37(\mathrm{t}$, $2 \mathrm{H}, J=8.0 \mathrm{~Hz}), 2.48(\mathrm{~s}, 3 \mathrm{H}), 2.91(\mathrm{t}, 2 \mathrm{H}, J=7.0 \mathrm{~Hz}), 3.33(\mathrm{~m}, 2 \mathrm{H}), 3.45(\mathrm{t}, 2 \mathrm{H}, J=7.0$ $\mathrm{Hz}), 7.60(\mathrm{~d}, 2 \mathrm{H}, J=8.5 \mathrm{~Hz}), 7.96(\mathrm{~d}, 2 \mathrm{H}, J=8.5 \mathrm{~Hz}) . \mathrm{MS}(\mathrm{ESI}): \mathrm{m} / \mathrm{z}=378.1(\mathrm{M}+\mathrm{H})^{+}$. HPLC2: $t_{\mathrm{R}} 11.7 \mathrm{~min}$, Purity $82 \%$.

\section{4-(2,4-dihydroxy-pyrimidin-5-yl)-N-[3-(2-oxo-pyrrolidin-1-yl)-propyl]-}

benzenesulfonamide (2.8hg). Using the above general procedure, 4-bromo-N-[3-(2oxo-pyrrolidin-1-yl)-propyl]-benzenesulfonamide $(0.25 \mathrm{mmol}), 2,4$-dihydroxypyrimidine5-boronic acid $(0.30 \mathrm{mmol})$, sodium carbonate $(0.75 \mathrm{mmol}), \mathrm{PS}-\mathrm{Pd}\left(\mathrm{Ph}_{3}\right)_{4}(0.025 \mathrm{mmol})$ and DME: $\mathrm{EtOH}: \mathrm{H}_{2} \mathrm{O}(5 \mathrm{~mL})$ were used to synthesize $\mathbf{2 . 8 h}$ as a white solid $(72 \%)$. ${ }^{1} \mathrm{HNMR}(500 \mathrm{MHz}, \mathrm{MeOD}): \delta 1.71(\mathrm{~m}, 2 \mathrm{H}), 2.03$ (m, 2H), $2.36(\mathrm{t}, 2 \mathrm{H}, J=8.0 \mathrm{~Hz}), 2.87$ 
(t, $2 \mathrm{H}, J=7.0 \mathrm{~Hz}), 3.30(\mathrm{~m}, 2 \mathrm{H}), 3.42(\mathrm{t}, 2 \mathrm{H}, J=7.0 \mathrm{~Hz}), 7.75(\mathrm{~s}, 1 \mathrm{H}), 7.79(\mathrm{~d}, 2 \mathrm{H}, J=$ $9.0 \mathrm{~Hz}), 7.86(\mathrm{~d}, 2 \mathrm{H}, J=8.5 \mathrm{~Hz}) . \mathrm{MS}(\mathrm{ESI}): \mathrm{m} / \mathrm{z}=393.1(\mathrm{M}+\mathrm{H})^{+}$. HPLC2: $t_{\mathrm{R}} 9.2 \mathrm{~min}$, Purity $>99 \%$.

2'-formyl-4'-methoxy-biphenyl-4-sulfonic acid [3-(2-oxo-pyrrolidin-1-yl)-propyl]amide (2.8hi). Using the above general procedure, 4-bromo-N-[3-(2-oxo-pyrrolidin-1yl)-propyl]-benzenesulfonamide $(0.25 \mathrm{mmol}), 2$-formyl-4-methoxyphenylboronic acid $(0.30 \mathrm{mmol})$, sodium carbonate $(0.75 \mathrm{mmol}), \mathrm{PS}-\mathrm{Pd}\left(\mathrm{Ph}_{3}\right)_{4}(0.025 \mathrm{mmol})$ and

DME:EtOH: $\mathrm{H}_{2} \mathrm{O}(5 \mathrm{~mL})$ were used to synthesize $\mathbf{2 . 8 h i}$ as a yellow solid (35\%). ${ }^{1} \mathrm{HNMR}$ $(500 \mathrm{MHz}, \mathrm{MeOD}): \delta 1.74(\mathrm{~m}, 2 \mathrm{H}), 2.04(\mathrm{~m}, 2 \mathrm{H}), 2.37(\mathrm{t}, 2 \mathrm{H}, J=8.0 \mathrm{~Hz}), 2.94(\mathrm{t}, 2 \mathrm{H}, J$ $=6.5 \mathrm{~Hz}), 3.32(\mathrm{~m}, 2 \mathrm{H}), 3.45(\mathrm{t}, 2 \mathrm{H}, J=7.0 \mathrm{~Hz}), 3.94(\mathrm{~s}, 3 \mathrm{H}), 7.33(\mathrm{~d}, 1 \mathrm{H}, J=8.5 \mathrm{~Hz})$, $7.47(\mathrm{~d}, 1 \mathrm{H}, J=8.5 \mathrm{~Hz}), 7.55(\mathrm{~d}, 1 \mathrm{H}, J=3.0 \mathrm{~Hz}), 7.61(\mathrm{~d}, 2 \mathrm{H}, J=8.5 \mathrm{~Hz}), 7.97(\mathrm{~d}, 2 \mathrm{H}, J$ $=8.0 \mathrm{~Hz}), 9.91(\mathrm{~s}, 1 \mathrm{H}) . \mathrm{MS}(\mathrm{ESI}): \mathrm{m} / \mathrm{z}=417.3(\mathrm{M}+\mathrm{H})^{+}$. HPLC2: $t_{\mathrm{R}} 12.6 \mathrm{~min}$, Purity $>$ $81 \%$.

3'-fluoro-4'-methoxy-biphenyl-4-sulfonic acid (6-methoxy-pyrimidin-4-yl)-amide (2.8ib). Using the above general procedure, 4-bromo-N-(6-methoxy-pyrimidin-4-yl)benzenesulfonamide $(0.25 \mathrm{mmol})$, 3-fluoro-4-methoxyphenylboronic acid $(0.30 \mathrm{mmol})$, sodium carbonate $(0.75 \mathrm{mmol}), \mathrm{PS}-\mathrm{Pd}\left(\mathrm{Ph}_{3}\right)_{4}(0.025 \mathrm{mmol})$ and DME:EtOH: $\mathrm{H}_{2} \mathrm{O}(5 \mathrm{~mL})$ were used to synthesize $\mathbf{2 . 8 i b}$ as a white solid $(88 \%)$. ${ }^{1} \mathrm{HNMR}(300 \mathrm{MHz}, \mathrm{DMSO}): \delta$ $3.68(\mathrm{~s}, 3 \mathrm{H}), 3.88(\mathrm{~s}, 3 \mathrm{H}), 5.92(\mathrm{~s}, 1 \mathrm{H}), 7.25(\mathrm{t}, 1 \mathrm{H}, J=9.0 \mathrm{~Hz}), 7.49(\mathrm{~d}, 1 \mathrm{H}, J=8.5 \mathrm{~Hz})$, $7.58(\mathrm{~d}, 1 \mathrm{H}, J=13.0 \mathrm{~Hz}), 7.67(\mathrm{~d}, 2 \mathrm{H}, J=4.0 \mathrm{~Hz}), 7.76(\mathrm{~d}, 2 \mathrm{H}, J=5.0 \mathrm{~Hz}), 8.04(\mathrm{~s}, 1 \mathrm{H})$. MS(ESI): $\mathrm{m} / \mathrm{z}=387.9(\mathrm{M}-\mathrm{H})^{-}$. HPLC2: $t_{\mathrm{R}} 12.9 \mathrm{~min}$, Purity $>99 \%$.

4'-(6-methoxy-pyrimidin-4-ylsulfamoyl)-biphenyl-4-carboxylic acid (2.8ic). Using the above general procedure, 4-bromo-N-(6-methoxy-pyrimidin-4-yl)benzenesulfonamide $(0.25 \mathrm{mmol})$, 4-carboxylphenylboronic acid $(0.30 \mathrm{mmol})$, sodium carbonate $(0.75 \mathrm{mmol})$, PS- $\left.\mathrm{Pd}_{(} \mathrm{Ph}_{3}\right)_{4}(0.025 \mathrm{mmol})$ and DME:EtOH: $\mathrm{H}_{2} \mathrm{O}(5 \mathrm{~mL})$ were used to synthesize 2.8ic as a white solid (78\%). ${ }^{1} \mathrm{HNMR}(300 \mathrm{MHz}, \mathrm{DMSO}): \delta 3.68$ (s, $3 \mathrm{H}), 5.93(\mathrm{~s}, 1 \mathrm{H}), 7.60(\mathrm{~d}, 2 \mathrm{H}, J=8.0 \mathrm{~Hz}), 7.69(\mathrm{~d}, 2 \mathrm{H}, J=8.5 \mathrm{~Hz}), 7.79(\mathrm{~d}, 2 \mathrm{H}, J=8.0$ $\mathrm{Hz}), 7.95(\mathrm{~d}, 2 \mathrm{H}, J=8.0 \mathrm{~Hz}), 8.04(\mathrm{~s}, 1 \mathrm{H}) . \mathrm{MS}(\mathrm{ESI}): \mathrm{m} / \mathrm{z}=386.1(\mathrm{M}+\mathrm{H})^{+} . \mathrm{HPLC} 2: t_{\mathrm{R}}$ 11.5 min, Purity $90 \%$.

4-benzo[1,3] dioxol-5-yl-N-(6-methoxy-pyrimidin-4-yl)-benzenesulfonamide (2.8ie). Using the above general procedure, 4-bromo-N-(6-methoxy-pyrimidin-4-yl)benzenesulfonamide $(0.25 \mathrm{mmol}), 1,3$-benxodioxol-5-ylboronic acid $(0.30 \mathrm{mmol})$, sodium carbonate $(0.75 \mathrm{mmol})$, PS- $\mathrm{Pd}\left(\mathrm{Ph}_{3}\right)_{4}(0.025 \mathrm{mmol})$ and DME:EtOH: $\mathrm{H}_{2} \mathrm{O}(5 \mathrm{~mL})$ were used to synthesize 2.8ie as a white solid (81\%). ${ }^{1} \mathrm{HNMR}(300 \mathrm{MHz}, \mathrm{DMSO}): \delta 3.68$ (s, $3 \mathrm{H}), 5.93(\mathrm{~s}, 1 \mathrm{H}), 6.06(\mathrm{~s}, 2 \mathrm{H}), 6.99(\mathrm{~d}, 1 \mathrm{H}, J=8.0 \mathrm{~Hz}), 7.17(\mathrm{~d}, 1 \mathrm{H}, J=8.0 \mathrm{~Hz}), 7.27(\mathrm{~s}$, $1 \mathrm{H}), 7.62(\mathrm{~d}, 2 \mathrm{H}, J=8.5 \mathrm{~Hz}), 7.75(\mathrm{~d}, 2 \mathrm{H}, J=8.5 \mathrm{~Hz}), 8.04$ (s, 1H). MS(ESI): $\mathrm{m} / \mathrm{z}=$ $384.0(\mathrm{M}-\mathrm{H})^{-}$. HPLC2: $t_{\mathrm{R}} 12.7 \mathrm{~min}$, Purity $>99 \%$.

4-(3,4-dimethyl-isoxazol-5-yl)-N-(6-methoxy-pyrimidin-4-yl)-benzenesulfonamide (2.9if). Using the above general procedure, 4-bromo-N-(6-methoxy-pyrimidin-4-yl)benzenesulfonamide $(0.25 \mathrm{mmol}), 3,5$-dimethyl-4-isoxazolylboronic acid $(0.30 \mathrm{mmol})$, sodium carbonate $(0.75 \mathrm{mmol}), \mathrm{PS}-\mathrm{Pd}\left(\mathrm{Ph}_{3}\right)_{4}(0.025 \mathrm{mmol})$ and DME:EtOH: $\mathrm{H}_{2} \mathrm{O}(5 \mathrm{~mL})$ 
were used to synthesize 2.8if as a light yellow solid (47\%). ${ }^{1} \mathrm{HNMR}\left(500 \mathrm{MHz}, \mathrm{CDCl}_{3}\right)$ : $\delta 2.29(\mathrm{~s}, 3 \mathrm{H}), 2.44(\mathrm{~s}, 3 \mathrm{H}), 4.00(\mathrm{~s}, 3 \mathrm{H}), 6.64(\mathrm{~s}, 1 \mathrm{H}), 7.41(\mathrm{~d}, 2 \mathrm{H}, J=8.5 \mathrm{~Hz}), 8.01$ (d, $2 \mathrm{H}, J=8.0 \mathrm{~Hz}), 8.56(\mathrm{~s}, 1 \mathrm{H}) . \mathrm{MS}(\mathrm{ESI}): \mathrm{m} / \mathrm{z}=361.1(\mathrm{M}+\mathrm{H})^{+}$. HPLC2: $t_{\mathrm{R}} 11.4 \mathrm{~min}$, Purity $83 \%$.

\section{4-(3,4-dimethyl-isoxazol-5-yl)-N-(6-methoxy-pyrimidin-4-yl)-benzenesulfonamide} (2.8ig). Using the above general procedure, 4-bromo-N-(6-methoxy-pyrimidin-4-yl)benzenesulfonamide $(0.25 \mathrm{mmol}), 2$,4-dihydroxypyrimidine-5-boronic acid $(0.30 \mathrm{mmol})$, sodium carbonate $(0.75 \mathrm{mmol}), \mathrm{PS}-\mathrm{Pd}\left(\mathrm{Ph}_{3}\right)_{4}(0.025 \mathrm{mmol})$ and DME:EtOH: $\mathrm{H}_{2} \mathrm{O}(5 \mathrm{~mL})$ were used to synthesize 2.8ig as a white solid $(71 \%)$. ${ }^{1} \mathrm{HNMR}\left(500 \mathrm{MHz}, \mathrm{CDCl}_{3}\right)$ : $\delta$ $3.93(\mathrm{~s}, 3 \mathrm{H}), 6.48(\mathrm{~s}, 1 \mathrm{H}), 7.59(\mathrm{~d}, 2 \mathrm{H}, J=8.0 \mathrm{~Hz}), 7.65(\mathrm{~s}, 1 \mathrm{H}), 8.00(\mathrm{~d}, 2 \mathrm{H}, J=7.0 \mathrm{~Hz})$, $8.33(\mathrm{~s}, 1 \mathrm{H})$. MS(ESI): $\mathrm{m} / \mathrm{z}=376.0(\mathrm{M}+\mathrm{H})^{+}$. HPLC2: $t_{\mathrm{R}} 10.1 \mathrm{~min}$, Purity $87 \%$.

4-(5-formyl-furan-2-yl)-N-(6-methoxy-pyrimidin-4-yl)-benzenesulfonamide (2.8ih). Using the above general procedure, 4-bromo-N-(6-methoxy-pyrimidin-4-yl)benzenesulfonamide $(0.25 \mathrm{mmol})$, 5-formyl-2-furylboronic acid $(0.30 \mathrm{mmol})$, sodium carbonate $(0.75 \mathrm{mmol}), \mathrm{PS}-\mathrm{Pd}\left(\mathrm{Ph}_{3}\right)_{4}(0.025 \mathrm{mmol})$ and DME:EtOH: $\mathrm{H}_{2} \mathrm{O}(5 \mathrm{~mL})$ were used to synthesize $\mathbf{2 . 8 i h}$ as a light yellow solid $(57 \%) .{ }^{1} \mathrm{HNMR}\left(500 \mathrm{MHz}, \mathrm{CDCl}_{3}\right)$ : $\delta$ $3.93(\mathrm{~s}, 3 \mathrm{H}), 6.47(\mathrm{~s}, 1 \mathrm{H}), 7.57(\mathrm{~d}, 1 \mathrm{H}, J=7.5 \mathrm{~Hz}), 7.58(\mathrm{~d}, 2 \mathrm{H}, J=8.0 \mathrm{~Hz}), 7.65(\mathrm{~d}, 1 \mathrm{H}$, $\mathrm{J}=7.0 \mathrm{~Hz}), 8.00(\mathrm{~d}, 2 \mathrm{H}, \mathrm{J}=7.5 \mathrm{~Hz}), 8.33(\mathrm{~s}, 1 \mathrm{H}) . \mathrm{MS}(\mathrm{ESI}): \mathrm{m} / \mathrm{z}=360.0(\mathrm{M}+\mathrm{H})^{+}$. HPLC2: $t_{\mathrm{R}} 10.1 \mathrm{~min}$, Purity $80 \%$.

\section{2'-formyl-4'-methoxy-biphenyl-4-sulfonic acid (6-methoxy-pyrimidin-4-yl)-amide} (2.8ii). Using the above general procedure, 4-bromo-N-(6-methoxy-pyrimidin-4-yl)benzenesulfonamide $(0.25 \mathrm{mmol}), 2$-formyl-4-methoxyphenylboronic acid $(0.30 \mathrm{mmol})$, sodium carbonate $(0.75 \mathrm{mmol}), \mathrm{PS}-\mathrm{Pd}\left(\mathrm{Ph}_{3}\right)_{4}(0.025 \mathrm{mmol})$ and DME:EtOH: $\mathrm{H}_{2} \mathrm{O}(5 \mathrm{~mL})$ were used to synthesize 2.8ii as a white solid (75\%). ${ }^{1} \mathrm{HNMR}(300 \mathrm{MHz}, \mathrm{DMSO}): \delta$ $3.69(\mathrm{~s}, 3 \mathrm{H}), 3.87$ (s, 3H), $5.96(\mathrm{~s}, 1 \mathrm{H}), 7.31-7.489$ (m, 3H), 7.40 (d, 2H, J=7.5 Hz), $7.83(\mathrm{~d}, 2 \mathrm{H}, J=8.0 \mathrm{~Hz}), 8.04(\mathrm{~s}, 1 \mathrm{H}), 9.83(\mathrm{~s}, 1 \mathrm{H}) . \quad \mathrm{MS}(\mathrm{ESI}): \mathrm{m} / \mathrm{z}=398.0(\mathrm{M}-\mathrm{H})^{-}$. HPLC2: $t_{\mathrm{R}} 12.3 \mathrm{~min}$, Purity $>99 \%$.

3'-fluoro-4'-methoxy-biphenyl-4-sulfonic acid benzothiazol-6-ylamide (2.8jb). Using the above general procedure, N-(2-hydroxy-1-methyl-2,2-diphenyl-ethyl)-3-(5-methyl[1,3,4] oxadiazol-2-yl)-benzenesulfonamide (0.25mmol), 3-fluoro-4methoxyphenylboronic acid $(0.30 \mathrm{mmol})$, sodium carbonate $(0.75 \mathrm{mmol}), \mathrm{PS}-\mathrm{Pd}\left(\mathrm{Ph}_{3}\right)_{4}$ $(0.025 \mathrm{mmol})$ and DME:EtOH: $\mathrm{H}_{2} \mathrm{O}(5 \mathrm{~mL})$ were used to synthesize $\mathbf{2 . 8 j b}$ as a yellow solid (65\%). ${ }^{1} \mathrm{HNMR}(500 \mathrm{MHz}, \mathrm{MeOD}): \delta 3.92(\mathrm{~s}, 3 \mathrm{H}), 7.15(\mathrm{t}, 1 \mathrm{H}, J=9.0 \mathrm{~Hz}), 7.23-$ $7.27(\mathrm{~m}, 2 \mathrm{H}), 7.30(\mathrm{dd}, 1 \mathrm{H}, J=2.0,8.5 \mathrm{~Hz}), 7.54(\mathrm{t}, 1 \mathrm{H}, J=8.0 \mathrm{~Hz}), 7.72(\mathrm{~d}, 1 \mathrm{H}, J=7.5$ $\mathrm{Hz}), 7.88$ (d, 1H, $J=8.0 \mathrm{~Hz}), 7.88-7.90$ (m, 2H), 7.94 (d, 1H, $J=9.0 \mathrm{~Hz}), 9.17(\mathrm{~s}, 1 \mathrm{H})$. MS(ESI): $\mathrm{m} / \mathrm{z}=415.1(\mathrm{M}+\mathrm{H})^{+}$. HPLC2: $t_{\mathrm{R}} 13.6 \mathrm{~min}$, Purity $>99 \%$.

4'-(benzothiazol-6-ylsulfamoyl)-biphenyl-4-carboxylic acid (2.8jc). Using the above general procedure, N-(2-hydroxy-1-methyl-2,2-diphenyl-ethyl)-3-(5-methyl$[1,3,4]$ oxadiazol-2-yl)-benzenesulfonamide $(0.25 \mathrm{mmol})$, 4-carboxylphenylboronic acid $(0.30 \mathrm{mmol})$, sodium carbonate $(0.75 \mathrm{mmol}), \mathrm{PS}-\mathrm{Pd}\left(\mathrm{Ph}_{3}\right)_{4}(0.025 \mathrm{mmol})$ and DME:EtOH: $\mathrm{H}_{2} \mathrm{O}(5 \mathrm{~mL})$ were used to synthesize $\mathbf{2 . 8 j c}$ as a yellow solid $(48 \%) .{ }^{1} \mathrm{HNMR}$ 
(500MHz, MeOD): $\delta 7.31(\mathrm{dd}, 1 \mathrm{H}, J=2.0,8.5 \mathrm{~Hz}), 7.49(\mathrm{t}, 1 \mathrm{H}, J=8.0 \mathrm{~Hz}), 7.60(\mathrm{~d}$, $2 \mathrm{H}, J=8.0 \mathrm{~Hz}), 7.81(\mathrm{~d}, 1 \mathrm{H}, J=7.5 \mathrm{~Hz}), 7.89(\mathrm{~d}, 1 \mathrm{H}, J=8.0 \mathrm{~Hz}), 7.91(\mathrm{~d}, 1 \mathrm{H}, J=2.0$ $\mathrm{Hz}), 7.95$ (d, 1H, $J=9.0 \mathrm{~Hz}), 7.99$ (t, 1H, $J=2.0 \mathrm{~Hz}), 8.09$ (d, 2H, $J=8.5), 9.17(\mathrm{~s}, 1 \mathrm{H})$. MS(ESI): $\mathrm{m} / \mathrm{z}=411.1(\mathrm{M}+\mathrm{H})^{+}$. HPLC2: $t_{\mathrm{R}} 12.4 \mathrm{~min}$, Purity $89 \%$.

5-[4-(benzothiazol-6-ylsulfamoyl)-phenyl]-thiophene-2-carboxylic acid (2.8jd). Using the above general procedure, N-(2-hydroxy-1-methyl-2,2-diphenyl-ethyl)-3-(5methyl-[1,3,4] oxadiazol-2-yl)-benzenesulfonamide $(0.25 \mathrm{mmol}), 5$-(dihydroxylboryl)-2thiophenecarboxylic acid $(0.30 \mathrm{mmol})$, sodium carbonate $(0.75 \mathrm{mmol}), \mathrm{PS}-\mathrm{Pd}\left(\mathrm{Ph}_{3}\right)_{4}$ (0.025 mmol) and DME:EtOH: $\mathrm{H}_{2} \mathrm{O}(5 \mathrm{~mL})$ were used to synthesize $\mathbf{2 . 8 j d}$ as a yellow solid (49\%). ${ }^{1} \mathrm{HNMR}(500 \mathrm{MHz}, \mathrm{MeOD}): \delta 7.29$ (dd, 1H, $\left.J=2.0,8.5 \mathrm{~Hz}\right), 7.49$ (t, $2 \mathrm{H}, J$ $=7.5 \mathrm{~Hz}), 7.57(\mathrm{~d}, 1 \mathrm{H}, J=7.5 \mathrm{~Hz}), 7.79(\mathrm{~d}, 2 \mathrm{H}, J=8.5 \mathrm{~Hz}), 7.84(\mathrm{~d}, 1 \mathrm{H}, J=8.5 \mathrm{~Hz})$, $7.91(\mathrm{~d}, 1 \mathrm{H}, J=2.0 \mathrm{~Hz}), 9.15(\mathrm{~s}, 1 \mathrm{H}) . \mathrm{MS}(\mathrm{ESI}): \mathrm{m} / \mathrm{z}=417.0(\mathrm{M}+\mathrm{H})^{+}$. HPLC2: $t_{\mathrm{R}} 11.7$ min, Purity $88 \%$.

4-benzo[1,3]dioxol-5-yl-N-benzothiazol-6-yl-benzenesulfonamide (2.8je). Using the above general procedure, N-(2-hydroxy-1-methyl-2,2-diphenyl-ethyl)-3-(5-methyl[1,3,4] oxadiazol-2-yl)-benzenesulfonamide (0.25mmol), 1,3-benxodioxol-5-ylboronic acid $(0.30 \mathrm{mmol})$, sodium carbonate $(0.75 \mathrm{mmol}), \mathrm{PS}-\mathrm{Pd}\left(\mathrm{Ph}_{3}\right)_{4}(0.025 \mathrm{mmol})$ and DME:EtOH: $\mathrm{H}_{2} \mathrm{O}(5 \mathrm{~mL})$ were used to synthesize $\mathbf{2 . 8 j e}$ as a yellow solid $(67 \%) .{ }^{1} \mathrm{HNMR}$ $(500 \mathrm{MHz}, \mathrm{MeOD}): \delta 6.01(\mathrm{~s}, 2 \mathrm{H}), 6.95(\mathrm{~d}, 1 \mathrm{H}, J=8.5 \mathrm{~Hz}), 7.30(\mathrm{dd}, 1 \mathrm{H}, J=2.0,8.5$ $\mathrm{Hz}), 7.52$ (t, $1 \mathrm{H}, J=8.0 \mathrm{~Hz}), 7.70(\mathrm{~d}, 1 \mathrm{H}, J=7.5 \mathrm{~Hz}), 7.74(\mathrm{~d}, 2 \mathrm{H}, J=7.5 \mathrm{~Hz}), 7.85$ (d, $1 \mathrm{H}, J=2.0 \mathrm{~Hz}), 7.89(\mathrm{~d}, 1 \mathrm{H}, J=2.0 \mathrm{~Hz}), 7.94(\mathrm{~d}, 1 \mathrm{H}, J=8.5 \mathrm{~Hz}), 9.17(\mathrm{~s}, 1 \mathrm{H})$. MS(ESI): $\mathrm{m} / \mathrm{z}=411.1(\mathrm{M}+\mathrm{H})^{+}$. HPLC2: $t_{\mathrm{R}} 13.4 \mathrm{~min}$, Purity $>99 \%$.

$\mathrm{N}$-benzothiazol-6-yl-4-(3,4-dimethyl-isoxazol-5-yl)-benzenesulfonamide (2.8jf). Using the above general procedure, N-(2-hydroxy-1-methyl-2,2-diphenyl-ethyl)-3-(5methyl-[1,3,4]oxadiazol-2-yl)-benzenesulfonamide $(0.25 \mathrm{mmol}), 3,5$-dimethyl-4isoxazolylboronic acid $(0.30 \mathrm{mmol})$, sodium carbonate $(0.75 \mathrm{mmol}), \mathrm{PS}-\mathrm{Pd}\left(\mathrm{Ph}_{3}\right)_{4}(0.025$ mmol) and DME:EtOH: $\mathrm{H}_{2} \mathrm{O}(5 \mathrm{~mL})$ were used to synthesize 2.8jf as a yellow solid (84\%). ${ }^{1} \mathrm{HNMR}(500 \mathrm{MHz}, \mathrm{MeOD}): \delta 2.02$ (s, 3H), 2.19 (s, 3H), 7.30 (dd, 1H, J=2.0, $8.5 \mathrm{~Hz}), 7.56(\mathrm{~d}, 1 \mathrm{H}, J=8.0 \mathrm{~Hz}), 7.64(\mathrm{t}, 1 \mathrm{H}, J=7.5 \mathrm{~Hz}), 7.87(\mathrm{~d}, 1 \mathrm{H}, J=7.5 \mathrm{~Hz}), 7.91$ $(\mathrm{d}, 1 \mathrm{H}, J=2.0 \mathrm{~Hz}), 7.94(\mathrm{~d}, 1 \mathrm{H}, J=9.0 \mathrm{~Hz}), 9.29(\mathrm{~s}, 1 \mathrm{H}) . \mathrm{MS}(\mathrm{ESI}): \mathrm{m} / \mathrm{z}=386.0$ $(\mathrm{M}+\mathrm{H})^{+}$. HPLC2: $t_{\mathrm{R}} 12.5 \mathrm{~min}$, Purity $94 \%$.

$\mathrm{N}$-benzothiazol-6-yl-4-(2,4-dihydroxy-pyrimidin-5-yl)-benzenesulfonamide (2.8jg). Using the above general procedure, N-(2-hydroxy-1-methyl-2,2-diphenyl-ethyl)-3-(5methyl-[1,3,4]oxadiazol-2-yl)-benzenesulfonamide (0.25 mmol), 2,4dihydroxypyrimidine-5-boronic acid $(0.30 \mathrm{mmol})$, sodium carbonate $(0.75 \mathrm{mmol})$, PS$\mathrm{Pd}\left(\mathrm{Ph}_{3}\right)_{4}(0.025 \mathrm{mmol})$ and DME:EtOH: $\mathrm{H}_{2} \mathrm{O}(5 \mathrm{~mL})$ were used to synthesize 2.8jg as a light yellow solid (58\%). ${ }^{1} \mathrm{HNMR}(500 \mathrm{MHz}, \mathrm{MeOD}): \delta 7.31(\mathrm{dd}, 1 \mathrm{H}, J=2.0,9.0 \mathrm{~Hz})$, 7.48 (t, 1H, J=7.5 Hz), 7.59 (s, 1H), 7.69 (d, 1H, $J=7.5 \mathrm{~Hz}), 7.73(\mathrm{~d}, 1 \mathrm{H}, J=8.0 \mathrm{~Hz})$, $7.87(\mathrm{~d}, 1 \mathrm{H}, J=2.5 \mathrm{~Hz}), 7.91(\mathrm{~d}, 1 \mathrm{H}, J=8.5 \mathrm{~Hz}), 8.10(\mathrm{t}, 1 \mathrm{H}, J=2.0 \mathrm{~Hz}), 9.15(\mathrm{~s}, 1 \mathrm{H})$. MS(ESI): $\mathrm{m} / \mathrm{z}=401.0(\mathrm{M}+\mathrm{H})^{+}$. HPLC2: $t_{\mathrm{R}} 10.4 \mathrm{~min}$, Purity $>99 \%$. 
$\mathrm{N}$-benzothiazol-6-yl-4-(5-formyl-furan-2-yl)-benzenesulfonamide (2.8jh). Using the above general procedure, $\mathrm{N}$-(2-hydroxy-1-methyl-2,2-diphenyl-ethyl)-3-(5-methyl[1,3,4] oxadiazol-2-yl)-benzenesulfonamide $(0.25 \mathrm{mmol})$, 5-formyl-2-furylboronic acid $(0.30 \mathrm{mmol})$, sodium carbonate $(0.75 \mathrm{mmol}), \mathrm{PS}-\mathrm{Pd}\left(\mathrm{Ph}_{3}\right)_{4}(0.025 \mathrm{mmol})$ and

DME:EtOH: $\mathrm{H}_{2} \mathrm{O}(5 \mathrm{~mL})$ were used to synthesize $\mathbf{2 . 8 j h}$ as a yellow solid $(64 \%) .{ }^{1} \mathrm{HNMR}$ (500MHz, MeOD): $\delta 7.27(\mathrm{dd}, 1 \mathrm{H}, J=2.0,9.0 \mathrm{~Hz}), 7.49(\mathrm{t}, 2 \mathrm{H}, J=8.0 \mathrm{~Hz}), 7.57(\mathrm{t}, 1 \mathrm{H}$, $J=7.0 \mathrm{~Hz}), 7.79(\mathrm{~d}, 1 \mathrm{H}, J=8.5 \mathrm{~Hz}), 7.84(\mathrm{~d}, 2 \mathrm{H}, J=2.0 \mathrm{~Hz}), 7.91(\mathrm{~d}, 1 \mathrm{H}, J=8.5 \mathrm{~Hz})$, $9.15(\mathrm{~s}, 1 \mathrm{H})$. MS(ESI): $\mathrm{m} / \mathrm{z}=384.6(\mathrm{M}-\mathrm{H})^{-}$. HPLC2: $t_{\mathrm{R}} 11.7 \mathrm{~min}$, Purity $>99 \%$.

2-(3'-fluoro-4'-methoxy-biphenyl-4-sulfonylamino)-3-phenyl-propionic acid $(2.8 \mathrm{~kb})$. Using the above general procedure, 2-(4-bromo-benzenesulfonylamino)-3-phenylpropionic acid methyl ester $(0.25 \mathrm{mmol}), 3$-fluoro-4-methoxyphenylboronic acid $(0.30 \mathrm{mmol})$, sodium carbonate $(0.75 \mathrm{mmol}), \mathrm{PS}-\mathrm{Pd}\left(\mathrm{Ph}_{3}\right)_{4}(0.025 \mathrm{mmol})$ and DME:EtOH: $\mathrm{H}_{2} \mathrm{O}(5 \mathrm{~mL})$ were used to synthesize $\mathbf{2 . 8 k b}$ as a light yellow solid $(77 \%)$. ${ }^{1} \mathrm{HNMR}(500 \mathrm{MHz}, \mathrm{MeOD}): \delta 2.90(\mathrm{dd}, 1 \mathrm{H}, J=4.0,13.0 \mathrm{~Hz}), 3.06(\mathrm{dd}, 1 \mathrm{H}, J=5.5$, $13.0 \mathrm{~Hz}), 3.90(\mathrm{~s}, 3 \mathrm{H}), 4.10(\mathrm{~m}, 1 \mathrm{H}), 7.15(\mathrm{~m}, 5 \mathrm{H}), 7.28(\mathrm{t}, 1 \mathrm{H}, J=9.0 \mathrm{~Hz}), 7.56(\mathrm{~d}, 1 \mathrm{H}, J$ $=9.0 \mathrm{~Hz}), 7.66(\mathrm{~d}, 1 \mathrm{H}, J=13.0 \mathrm{~Hz}), 7.75(\mathrm{~d}, 2 \mathrm{H}, J=8.5 \mathrm{~Hz}), 7.82(\mathrm{~d}, 2 \mathrm{H}, J=8.5 \mathrm{~Hz})$. MS(ESI): $\mathrm{m} / \mathrm{z}=427.9(\mathrm{M}-\mathrm{H})^{-}$. HPLC2: $t_{\mathrm{R}} 13.3 \mathrm{~min}$, Purity $>99 \%$.

4'-(1-carboxy-2-phenyl-ethylsulfamoyl)-biphenyl-4-carboxylic acid (2.8kc). Using the above general procedure, 2-(4-bromo-benzenesulfonylamino)-3-phenyl-propionic acid methyl ester $(0.25 \mathrm{mmol}), 4$-carboxylphenylboronic acid $(0.30 \mathrm{mmol})$, sodium carbonate $(0.75 \mathrm{mmol}), \mathrm{PS}-\mathrm{Pd}\left(\mathrm{Ph}_{3}\right)_{4}(0.025 \mathrm{mmol})$ and DME:EtOH: $\mathrm{H}_{2} \mathrm{O}(5 \mathrm{~mL})$ were used to synthesize $2.8 \mathrm{kc}$ as a white solid (70\%). ${ }^{1} \mathrm{HNMR}(500 \mathrm{MHz}, \mathrm{MeOD}): \delta 2.93(\mathrm{~d}$, $1 \mathrm{H}, J=11.0 \mathrm{~Hz}), 3.05(\mathrm{~d}, 1 \mathrm{H}, J=12.0 \mathrm{~Hz}), 4.10(\mathrm{~m}, 1 \mathrm{H}), 7.18(\mathrm{~m}, 5 \mathrm{H}), 7.66(\mathrm{~d}, 2 \mathrm{H}, J=$ $7.0 \mathrm{~Hz}), 7.80(\mathrm{bs}, 4 \mathrm{H}), 8.00(\mathrm{~d}, 2 \mathrm{H}, J=6.5 \mathrm{~Hz}) . \mathrm{MS}(\mathrm{ESI}): \mathrm{m} / \mathrm{z}=423.9(\mathrm{M}-\mathrm{H})^{-}$. HPLC2: $t_{\mathrm{R}} 12.2 \mathrm{~min}$, Purity $93 \%$.

5-[4-(1-carboxy-2-phenyl-ethylsulfamoyl)-phenyl]-thiophene-2-carboxylic acid (2.8kd). Using the above general procedure, 2-(4-bromo-benzenesulfonylamino)-3phenyl-propionic acid methyl ester $(0.25 \mathrm{mmol}), 5$-(dihydroxylboryl)-2-

thiophenecarboxylic acid $(0.30 \mathrm{mmol})$, sodium carbonate $(0.75 \mathrm{mmol}), \mathrm{PS}-\mathrm{Pd}\left(\mathrm{Ph}_{3}\right)_{4}$ $(0.025 \mathrm{mmol})$ and DME:EtOH: $\mathrm{H}_{2} \mathrm{O}(5 \mathrm{~mL})$ were used to synthesize $\mathbf{2 . 8 k d}$ as a yellow solid (55\%). ${ }^{1} \mathrm{HNMR}(500 \mathrm{MHz}, \mathrm{MeOD}): \delta 2.88(\mathrm{dd}, 1 \mathrm{H}, J=8.5,14.0 \mathrm{~Hz}), 3.10(\mathrm{dd}$, $1 \mathrm{H}, J=5.5,14.0 \mathrm{~Hz}), 4.10(\mathrm{~m}, 1 \mathrm{H}), 7.18(\mathrm{~m}, 5 \mathrm{H}), 7.53(\mathrm{~d}, 1 \mathrm{H}, J=9.0 \mathrm{~Hz}), 7.57(\mathrm{~d}, 1 \mathrm{H}, J$ $=9.0), 7.71(\mathrm{~d}, 2 \mathrm{H}, J=8.5 \mathrm{~Hz}), 7.77(\mathrm{~d}, 2 \mathrm{H}, J=6.5 \mathrm{~Hz}) . \mathrm{MS}(\mathrm{ESI}): \mathrm{m} / \mathrm{z}=432.1$

$(\mathrm{M}+\mathrm{H})^{+}$. HPLC2: $t_{\mathrm{R}} 12.7$ min, Purity $80 \%$.

2-(4-benzo[1,3]dioxol-5-yl-benzenesulfonylamino)-3-phenyl-propionic acid (2.8ke). Using the above general procedure, 2-(4-bromo-benzenesulfonylamino)-3-phenylpropionic acid methyl ester $(0.25 \mathrm{mmol}), 1,3$-benxodioxol-5-ylboronic acid $(0.30 \mathrm{mmol})$, sodium carbonate $(0.75 \mathrm{mmol}), \mathrm{PS}-\mathrm{Pd}\left(\mathrm{Ph}_{3}\right)_{4}(0.025 \mathrm{mmol})$ and DME:EtOH: $\mathrm{H}_{2} \mathrm{O}(5 \mathrm{~mL})$ were used to synthesize 2.8ke as a light yellow solid (65\%) ${ }^{1} \mathrm{HNMR}(500 \mathrm{MHz}, \mathrm{MeOD})$ : $\delta 2.92(\mathrm{~d}, 1 \mathrm{H}, J=13.0 \mathrm{~Hz}), 3.06(\mathrm{~d}, 1 \mathrm{H}, J=11.5 \mathrm{~Hz}), 4.10(\mathrm{~m}, 1 \mathrm{H}), 6.09(\mathrm{~s}, 2 \mathrm{H}), 7.13$ $(\mathrm{d}, 1 \mathrm{H}, J=8.5 \mathrm{~Hz}), 7.17(\mathrm{~m}, 5 \mathrm{H}), 7.23(\mathrm{~d}, 1 \mathrm{H}, J=8.5 \mathrm{~Hz}), 7.33(\mathrm{~s}, 1 \mathrm{H}), 7.74(\mathrm{bs}, 4 \mathrm{H})$. MS(ESI): $\mathrm{m} / \mathrm{z}=423.9(\mathrm{M}-\mathrm{H})^{-}$. HPLC2: $t_{\mathrm{R}} 13.2 \mathrm{~min}$, Purity $91 \%$. 
2-[4-(3,4-dimethyl-isoxazol-5-yl)-benzenesulfonylamino]-3-phenyl-propionic acid (2.8kf). Using the above general procedure, 2-(4-bromo-benzenesulfonylamino)-3phenyl-propionic acid methyl ester $(0.25 \mathrm{mmol}), 3,5$-dimethyl-4-isoxazolylboronic acid $(0.30 \mathrm{mmol})$, sodium carbonate $(0.75 \mathrm{mmol}), \mathrm{PS}-\mathrm{Pd}\left(\mathrm{Ph}_{3}\right)_{4}(0.025 \mathrm{mmol})$ and

DME:EtOH: $\mathrm{H}_{2} \mathrm{O}(5 \mathrm{~mL})$ were used to synthesize $\mathbf{2 . 8 k f}$ as a yellow solid $(74 \%) .{ }^{1} \mathrm{HNMR}$ (500MHz, MeOD): $\delta 2.34(\mathrm{~s}, 3 \mathrm{H}), 2.36(\mathrm{~s}, 3 \mathrm{H}), 2.84(\mathrm{dd}, 1 \mathrm{H}, J=9.0,14.0 \mathrm{~Hz}), 3.09$ $(\mathrm{dd}, 1 \mathrm{H}, J=5.0,14.0 \mathrm{~Hz}), 4.06(\mathrm{~m}, 1 \mathrm{H}), 7.17(\mathrm{~m}, 5 \mathrm{H}), 7.53(\mathrm{~d}, 2 \mathrm{H}, J=4.5 \mathrm{~Hz}), 7.57$ (d, $2 \mathrm{H}, J=9.0 \mathrm{~Hz}) . \mathrm{MS}(\mathrm{ESI}): \mathrm{m} / \mathrm{z}=401.1(\mathrm{M}+\mathrm{H})^{+}$. HPLC2: $t_{\mathrm{R}} 12.2 \mathrm{~min}$, Purity $83 \%$.

2-[4-(2,4-dihydroxy-pyrimidin-5-yl)-benzenesulfonylamino]-3-phenyl-propionic acid (2.8kg). Using the above general procedure, 2-(4-bromo-benzenesulfonylamino)-3phenyl-propionic acid methyl ester $(0.25 \mathrm{mmol}), 2,4$-dioxoheahyropyrimidin-5-yl boronic acid $(0.30 \mathrm{mmol})$, sodium carbonate $(0.75 \mathrm{mmol}), \mathrm{PS}-\mathrm{Pd}\left(\mathrm{Ph}_{3}\right)_{4}(0.025 \mathrm{mmol})$ and DME:EtOH: $\mathrm{H}_{2} \mathrm{O}(5 \mathrm{~mL})$ were used to synthesize $\mathbf{2 . 8 k g}$ as a white solid $(84 \%) .{ }^{1} \mathrm{HNMR}$ (500MHz, MeOD): $\delta 2.88(\mathrm{dd}, 1 \mathrm{H}, J=8.5,14.0 \mathrm{~Hz}), 3.08(\mathrm{dd}, 1 \mathrm{H}, J=6.0,13.5 \mathrm{~Hz})$, $4.07(\mathrm{~m}, 1 \mathrm{H}), 7.18(\mathrm{~m}, 5 \mathrm{H}), 7.64(\mathrm{~d}, 2 \mathrm{H}, J=9.0 \mathrm{~Hz}), 7.68(\mathrm{~d}, 2 \mathrm{H}, J=9.0 \mathrm{~Hz}), 7.70(\mathrm{~s}$, 1H). MS(ESI): $\mathrm{m} / \mathrm{z}=416.1(\mathrm{M}+\mathrm{H})^{+}$. HPLC2: $t_{\mathrm{R}} 10.2 \mathrm{~min}$, Purity $>99 \%$.

2-[4-(5-formyl-furan-2-yl)-benzenesulfonylamino]-3-phenyl-propionic acid (2.8kh). Using the above general procedure, 2-(4-bromo-benzenesulfonylamino)-3-phenylpropionic acid methyl ester $(0.25 \mathrm{mmol}), 5$-formyl-2-furylboronic acid $(0.30 \mathrm{mmol})$, sodium carbonate $(0.75 \mathrm{mmol}), \mathrm{PS}-\mathrm{Pd}\left(\mathrm{Ph}_{3}\right)_{4}(0.025 \mathrm{mmol})$ and DME:EtOH: $\mathrm{H}_{2} \mathrm{O}(5 \mathrm{~mL})$ were used to synthesize $\mathbf{2 . 8 k h}$ as a light yellow solid (78\%). ${ }^{1} \mathrm{HNMR}(500 \mathrm{MHz}, \mathrm{MeOD})$ : $\delta 2.89(\mathrm{dd}, 1 \mathrm{H}, J=8.5,14.0 \mathrm{~Hz}), 3.10(\mathrm{dd}, 1 \mathrm{H}, J=5.0,13.5 \mathrm{~Hz}), 4.10(\mathrm{~m}, 1 \mathrm{H}), 7.18(\mathrm{~m}$, $5 \mathrm{H}), 7.53(\mathrm{~d}, 1 \mathrm{H}, J=8.5 \mathrm{~Hz}), 7.57(\mathrm{~d}, 1 \mathrm{H}, J=9.0 \mathrm{~Hz}), 7.71(\mathrm{~d}, 2 \mathrm{H}, J=8.5 \mathrm{~Hz}), 7.77$ (d, $2 \mathrm{H}, J=8.5 \mathrm{~Hz})$. MS(ESI): $\mathrm{m} / \mathrm{z}=400.1(\mathrm{M}+\mathrm{H})^{+}$. HPLC2: $t_{\mathrm{R}} 12.7 \mathrm{~min}$, Purity $86 \%$. HPLC(254nm) 86\%, rt $=12.717$.

2-(2'-formyl-4'-methoxy-biphenyl-4-sulfonylamino)-3-phenyl-propionic acid (2.8ki). Using the above general procedure, 2-(4-bromo-benzenesulfonylamino)-3-phenylpropionic acid methyl ester $(0.25 \mathrm{mmol}), 2$-formyl-4-methoxyphenylboronic acid $(0.30$ mmol), sodium carbonate $(0.75 \mathrm{mmol}), \mathrm{PS}-\mathrm{Pd}\left(\mathrm{Ph}_{3}\right)_{4}(0.025 \mathrm{mmol})$ and DME:EtOH: $\mathrm{H}_{2} \mathrm{O}$ ( $5 \mathrm{~mL}$ ) were used to synthesize $\mathbf{2 . 8 k i}$ as a white solid $(86 \%)$. ${ }^{1} \mathrm{HNMR}$ (500MHz, MeOD): $\delta 2.89(\mathrm{dd}, 1 \mathrm{H}, J=9.0,13.5 \mathrm{~Hz}), 3.11(\mathrm{dd}, 1 \mathrm{H}, J=5.5,13.5 \mathrm{~Hz}), 3.94(\mathrm{~s}, 3 \mathrm{H})$, $4.11(\mathrm{~m}, 1 \mathrm{H}), 7.21(\mathrm{~m}, 6 \mathrm{H}), 7.33(\mathrm{~d}, 1 \mathrm{H}, J=8.5 \mathrm{~Hz}), 7.43(\mathrm{~d}, 1 \mathrm{H}, J=9.5 \mathrm{~Hz}), 7.75(\mathrm{~d}$, $2 \mathrm{H}, J=8.5 \mathrm{~Hz}), 7.82(\mathrm{~d}, 2 \mathrm{H}, J=8.5 \mathrm{~Hz}) . \mathrm{MS}(\mathrm{ESI}): \mathrm{m} / \mathrm{z}=440.1(\mathrm{M}+\mathrm{H})^{+}$. HPLC2: $t_{\mathrm{R}}$ $13.0 \mathrm{~min}$, Purity $>99 \%$.

MIC Determinations

MIC values of the bi-aryl sulfonamides against $M$. tuberculosis H37Rv were determined by the micro broth dilution method according to NCCLS guidelines. A broth culture of $M$. tuberculosis was grown in Middlebrook $7 \mathrm{H} 9$ medium with 10\% ADC supplement to an $\mathrm{OD}_{600}$ of 0.4-0.6. The culture was diluted with $7 \mathrm{H} 9$ medium to an $\mathrm{OD}_{600}$ of 0.01 , and $100 \mu \mathrm{L}$ of these cells was then added to a microtiter plate containing 
serial dilutions of the nitrofuranyl amides for a final volume of $200 \mu \mathrm{L}$. The plates were incubated at $37^{\circ} \mathrm{C}$ for 7 days. The $\mathrm{MIC}_{90}$ was determined by visual inspection for wells with greater than $90 \%$ inhibition of growth. 


\section{CHAPTER 3: NOVEL INHIBITORS OF PHOSPHOLIPID BIOSYNTHESIS IN GRAM-POSITIVE BACTERIA}

\section{Introduction}

The widespread occurrence of resistance to current antibiotics by gram-positive bacteria, including methicillin resistant Staphylococcus aureus (MRSA), vancomycin resistant Enterococcus (VRE) and macrolide resistant Streptococcus pneumoniae, exemplifies the urgent need for the development of new antimicrobials to combat the growing menace of complicated infections. ${ }^{53}$ The sequencing of bacterial genomes has identified many new drug targets with the promise of introducing novel classes of drugs with different modes of action to overcome the problems associated with current therapies while avoiding cross-resistance. ${ }^{148}$ Among these attractive targets are the unique enzymes involved in the biosynthesis of lipids in bacteria. ${ }^{88,149,150}$ Accordingly, this chapter involves the design of inhibitors of bacterial phospholipid biosynthesis.

Phospholipid Biosynthesis

Phospholipids are abundant and essential membrane components in all bacterial species. They form the structural elements of the cell membrane, and disruption of their biosynthesis results in cell death. ${ }^{151}$ Phosphatidic acid is a key intermediate in the biosynthesis of bacterial membrane phospholipids, and is formed by the acylation of snglycerol-3-phosphate (G3P). ${ }^{152}$ In E. coli, phosphatidic acid biosynthesis is initiated by the PlsB acyltransferase that transfers a fatty acid from acyl-acyl carrier protein (ACP) to the 1-position of G3P (Figure 3.1a). ${ }^{152}$ There are a number of PlsB homologs in animals that perform the same function; however, PlsB is not universally expressed in bacteria. ${ }^{153}$ Specifically, it is not found in the clinically important Gram-positive bacteria, such as $S$. pneumonia and S. aureus. ${ }^{153}$ In some bacteria, such as Pseudomonas aeruginosa, the $p l s B$ gene is non-essential ${ }^{154}$ demonstrating the presence of an alternate pathway to the initiation of phosphatidic acid biosynthesis.

\section{Discovery of PlsX/PlsY}

Using S. pneumoniae as a representative, an alternate two-step pathway was recently discovered that is required for G3P acylation in Gram-positive pathogens (Figure 3.1b). ${ }^{153}$ The first step is catalyzed by PlsX, a soluble phosphate:acyl-ACP acyltransferase, that produces an acylphosphate $\left(\right.$ acyl- $\left.\mathrm{PO}_{4}\right)$ intermediate. The second step is catalyzed by $\mathrm{PlsY}$, an integral transmembrane acyl-PO $\mathrm{P}_{4}: \mathrm{G} 3 \mathrm{P}$ acyltransferase that transfers the acyl group from acyl- $\mathrm{PO}_{4}$ to the 1-position of G3P. The PlsX/PlsY pathway is the only route to membrane phospholipids in Firmicutes (Figure 3.2), ${ }^{153}$ which include the most clinically important Gram-positive bacteria, including Staphylococci,

Streptococci, and Enterococci. ${ }^{155}$ Importantly, there are no mammalian homologs of the 
a.
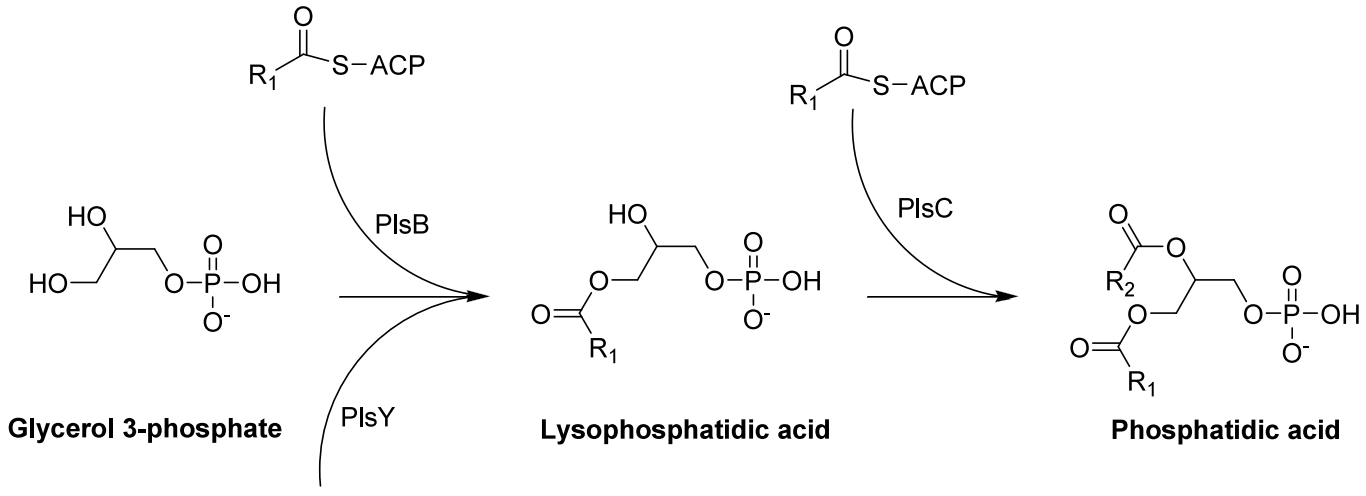

Lysophosphatidic acid

Phosphatidic acid

b.

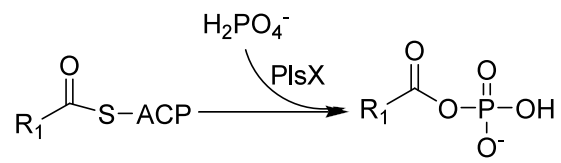

Figure 3.1: Phosphatidic Acid Formation. (a) Pathway in E. coli. (b) Pathway in $S$. pneumoniae.

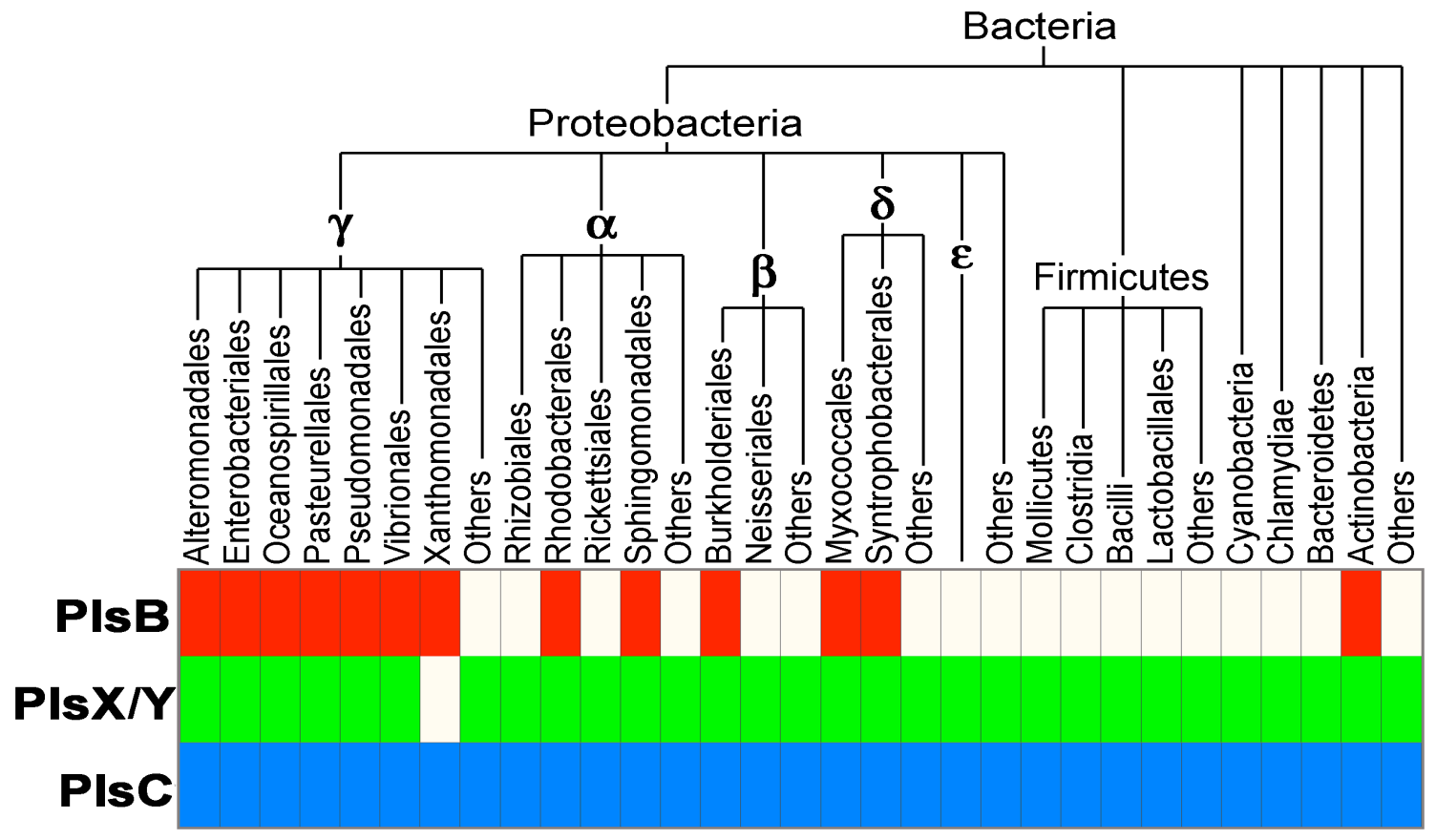

Figure 3.2: Distribution of pls Genes in Bacteria

Permission to reprint from: Lu, Y.J.; Zhang, Y.M.; Grimes K.D.; Qi, J.; Lee, R.E.; Rock C.O., Acyl-Phosphates Initiate Membrane Phospholipid Synthesis in Gram-Positive Pathogens. Molecular Cell 2006, 23, 765-72. ${ }^{153}$ 
$\mathrm{PlsX} / \mathrm{PlsY}$ pathway making it an attractive target for drug discovery. ${ }^{153} \mathrm{PlsC}$, is universally expressed in bacteria and completes the synthesis of phosphatidic acid by transferring an acyl chain from acyl-ACP to the 2-position of 1-acyl-G3P (Figure 3.1). ${ }^{153}$

Synthesis of Substrate

Research performed in this section began with the synthesis of monopalmitoyl phosphate, a biosynthetic intermediate used to validate the function of PlsX and Pls Y (Scheme 3.1). ${ }^{153}$ Though it seemed as if the synthesis of this substrate would be straightforward, it proved to be quite challenging due to the product's high lability and contrasting solubilities of the reagents. The synthesis of monopalmitoyl phosphate was finally achieved using the method of Lehninger (Scheme 3.1). ${ }^{156}$ Silver phosphate was reacted with anhydrous phosphoric acid in diethyl ether to form the monosilver phosphate salt. Next, palmitoyl chloride 3.1 in diethyl ether was added drop-wise to the resulting mixture generating the desired crude product. The resulting mixture was concentrated then recrystalized in warm benzene yielding monopalmitoyl phosphate $\mathbf{3 . 2}$ as a white powder with a $24 \%$ yield.

\section{Design of Substrate Mimics}

Studies performed by our collaborators at St. Jude Children's Research Hospital established that, in $S$. pneumoniae, two types of fatty acids were found at the first position of bacterial phospholipids: palmitic acid and cis-vaccenic acid. ${ }^{153}$ This information initiated the design and synthesis of acylphosphate mimetics as inhibitors of this newly discovered pathway. We focused on designing novel inhibitors of this pathway through the synthesis of stabilized homologs of the acyl- $\mathrm{PO}_{4}$ intermediate utilizing bioisosteric replacement strategies for the highly labile acyl- $\mathrm{PO}_{4}$ group. We began with the synthesis of known bioisosteric replacement strategies for the labile phosophate moiety in the form of phosphonates and phosphoramides containing the palmitic and cis-vaccenic acid groups. From analysis of the activity in this initial study, we learned that these compounds were good inhibitors of $S$. pneumoniae PlsY ( $\mathrm{SpPlsY}$ ). With this success, we decided to design and synthesize an expanded set of potential substrate-based inhibitors which included a series of phosphonates, phosphoramides, difluoromethyl phosphonates, and reverse-amide phosphonates having both saturated and unsaturated acyl chains of various lengths, as well as the replacement of the acyl chain with various aromatic and nonaromatic ring systems to further probe this pathway.

During our efforts to synthesize substrate mimics, we encountered the work of Aldrich et al., showing the design and the synthesis of non-ribosomal tRNA synthetase inhibitors, whose substrate was similar to the PlsY acylphosphate substrate. ${ }^{157-160}$ These inhibitors incorporated several bioisosteric replacement strategies for the labile phosphate moiety which included $\beta$-ketophosphonate, acylsulfamate, acylsulfamide, sulfamate, $\beta$ ketosulfonamide, $\alpha, \alpha$-difluoro- $\beta$-ketosulfonamide, acyltriazole, and vinylsulfonamide linkages. We chose to incorporate two of these bioisosteric replacements in our library of 
Scheme 3.1: Synthesis of Monopalmitoyl Phosphate

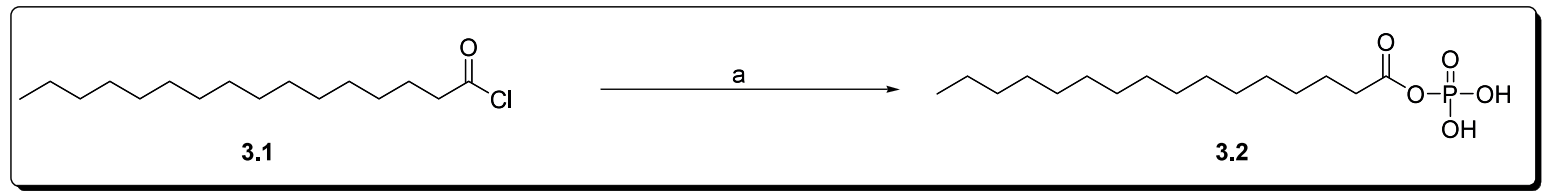

Reagents and Conditions: (a) Silver phosphate, Diethyl ether, rt, $1 \mathrm{~h}$. 
substrate mimics (sulfamates and sulfamides). We only sought to synthesize the palmitoyl and cis-vaccecinoyl or cis-oleoyl chains for our initial study, since from the previous studies we knew that these chains had the most significant activity. This work evaluated the study of six acyl- $\mathrm{PO}_{4}$ bioisosteric head groups combined with a series of acyl chains (Figure 3.3) to develop a preliminary structure activity relationship (SAR) for PlsY inhibition and anti-bacterial activity

\section{Synthesis}

Acylphosphonate derivatives were synthesized by reacting lithiated dimethyl methane phosphonate with the appropriate esters or acid chlorides $\mathbf{3 . 3}$ to yield the corresponding phosphonate esters in good yields 3.6a-h (Scheme 3.2). ${ }^{161}$ Diethyl $\alpha, \alpha-$ difluoromethyl phosphonate esters 3.7a,e,i,j were synthesized in an analogous manner from lithiated diethyl $\alpha, \alpha$-difluoromethyl phosphonate. ${ }^{162}$ All the phosphonate esters were cleaved with bromotrimethylsilane (TMSBr), to yield the desired phosphonic acids 3.6a-h, 3.7a,e,i,j. Acyl phosphoramides were prepared starting from the corresponding fatty acid potassium salts 3.8a-f. Acylation of 3.8a-f with ethylchloroformate yielded the anyhydrides 3.7a-f, which were subsequently reacted with the lithium salt of diethyl phosphoramidate to give acylphosphoramide esters 3.10a-f. ${ }^{163}$ Then, TMSBr mediated cleavage of the phosphoramide esters yielded the target acylphosphoramides 3.11a-f (Scheme 3.3). Reverse amide phosphonates were synthesized by coupling various amines 3.12a-d with diethylphosphonoacetic acid using 1-hydroxybenzotriazole (HOBt) and N-(3-dimethylaminopropyl)-N'-ethylcarbodiimide (EDCI) to form the corresponding phosphonate esters 3.13a-d, ${ }^{164}$ which were then deprotected with TMSBr to generate the target phosphonates 3.14a-d (Scheme 3.4).

The acylsulfamates and acylsulfamides were synthesized starting from the aminosulfonyl chloride 3.16, according to the protocol of Appel and Berger. ${ }^{165}$ Aminosulfonyl chloride $\mathbf{3 . 1 6}$ was treated with various alcohols or propylamine to generate the intermediate sulfamates 3.17a-d ${ }^{166}$ or sulfamide 3.18a,b. ${ }^{167}$ The sulfamates and sulfamide were then acylated with selected acid chlorides in the presence of triethylamine and catalytic 4-(dimethylamino) pyridine (DMAP) to form the desired acylsulfamates 3.19a-d and acylsulfamide 3.20a,b (Scheme 3.5).

\section{Results and Discussion}

The synthesized acyl- $\mathrm{PO}_{4}$ bioisosteres were tested for inhibition of the $S$. pneumoniae PlsX and PlsY (SpPlsX/Y) (Table 3.1). None of the compounds showed $S p \mathrm{PlsX}$ activity. For this reason, we focused primarily on PlsY inhibition for development. Compounds from all six of the bioisosteric head group series showed varying degrees of $S p P l s Y$ inhibition. The most potent inhibitors in each class contained saturated or unsaturated alkyl chains of 12 carbons or more. The weakest inhibitors included the shortest alkyl chains ranging from 4 to 11 or the equivalent. These results suggested that shorter chained analogs are not able to mimic the same interactions as the 


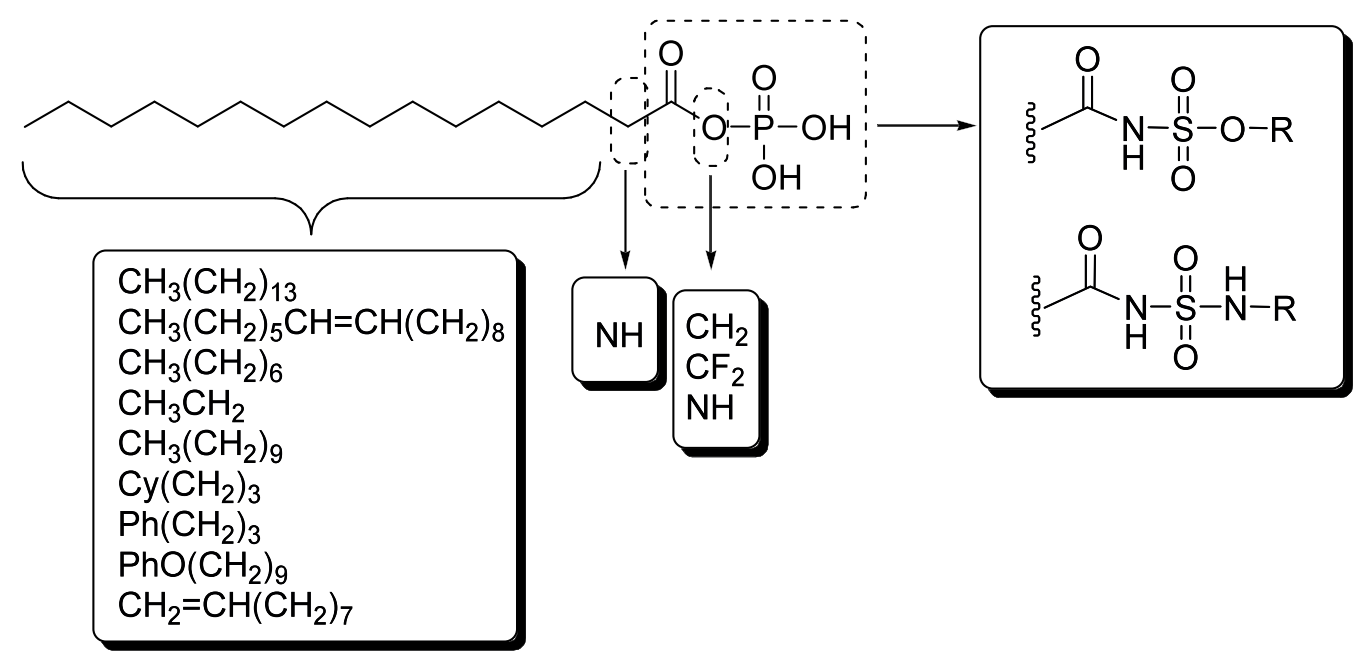

Figure 3.3: Design of Substrate Mimics of Acylphosphate.

Scheme 3.2: Synthesis of Ketophosphonates and Acyl $\alpha, \alpha$-Difluromethyl Phosphonates

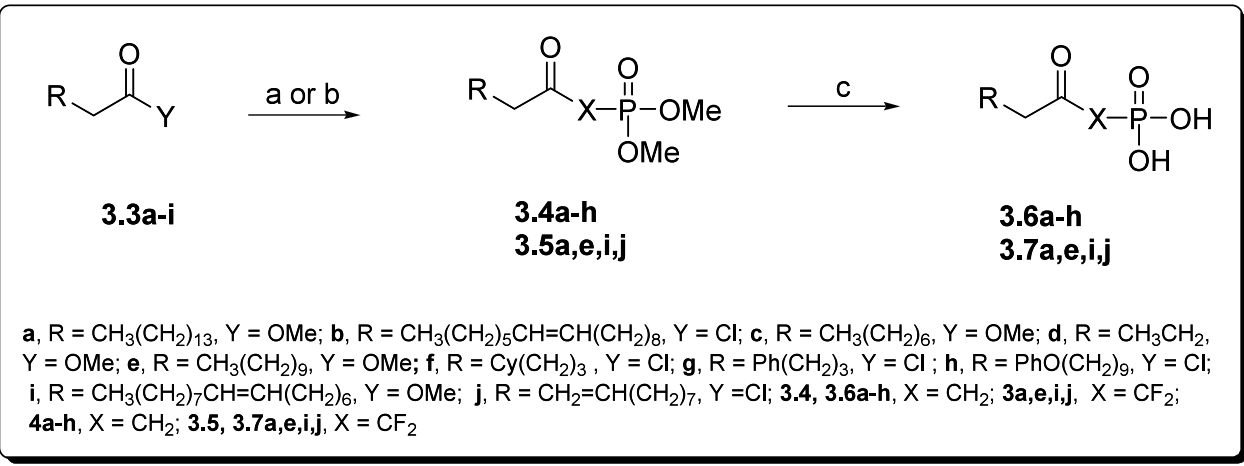

Reagents and Conditions: (a) Dimethyl methylphosphonate, BuLi, THF, $-78^{\circ} \mathrm{C}$, (b) Diethyl (difluoromethane) phosphonate, $\mathrm{LDA}, \mathrm{THF},-78^{\circ} \mathrm{C}$, (c) TMSBr, DCM, then $95 \% \mathrm{EtOH}$. 
Scheme 3.3: Synthesis of Acylphosphoramides

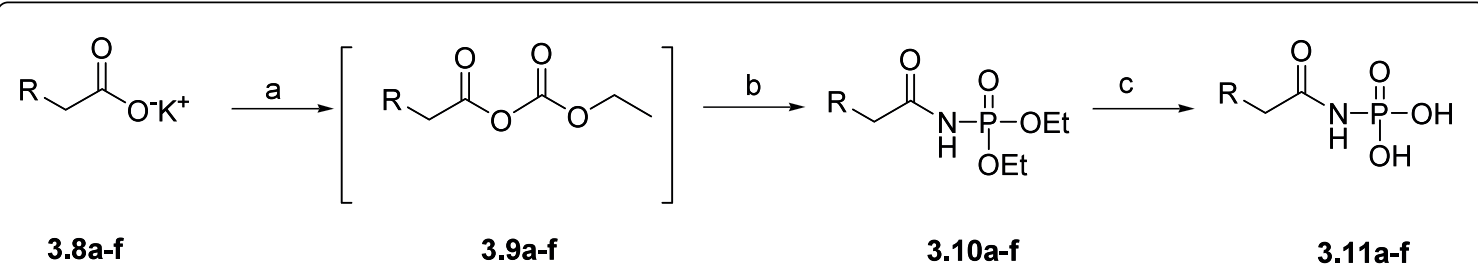

a, $\mathrm{R}=\mathrm{CH}_{3}\left(\mathrm{CH}_{2}\right)_{13} ; \mathbf{b}, \mathrm{R}=\mathrm{CH}_{3}\left(\mathrm{CH}_{2}\right)_{5} \mathrm{CH}=\mathrm{CH}\left(\mathrm{CH}_{2}\right)_{8} ; \mathbf{c}, \mathrm{R}=\mathrm{CH}_{3}\left(\mathrm{CH}_{2}\right)_{6} ; \mathbf{d}, \mathrm{R}=\mathrm{CH}_{3}\left(\mathrm{CH}_{2}\right)_{9} ; \mathbf{e}, \mathrm{R}=\mathrm{Cy}\left(\mathrm{CH}_{2}\right)_{3} ; \mathbf{f}, \mathrm{R}=\mathrm{PhO}\left(\mathrm{CH}_{2}\right)_{9}$

Reagents and Conditions: (a) Ethylcholoroformate, DCM; (b) Diethyl phosphoramidate, $\mathrm{BuLi}$, THF, $-78^{\circ} \mathrm{C}$, (c) TMSBr, DCM, then $95 \% \mathrm{EtOH}$.

\section{Scheme 3.4: Synthesis of Reverse Amide Phosphonates}

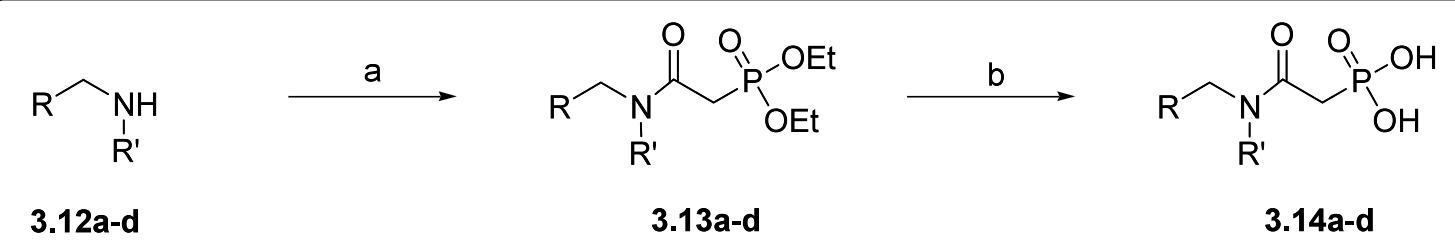

a, $\mathrm{R}=\mathrm{CH}_{3}\left(\mathrm{CH}_{2}\right)_{13}, \mathrm{R}^{\prime}=\mathrm{H} ; \mathbf{b}, \mathrm{R}=\mathrm{CH}_{3}\left(\mathrm{CH}_{2}\right)_{5} \mathrm{CH}=\mathrm{CH}\left(\mathrm{CH}_{2}\right)_{8}, \mathrm{R}^{\prime}=\mathrm{H} ; \mathbf{c}, \mathrm{R}=\mathrm{CH}_{3}\left(\mathrm{CH}_{2}\right)_{9}, \mathrm{R}^{\prime}=\mathrm{CH}_{3} ; \mathbf{d}, \mathrm{R}=\mathrm{CH}_{3}\left(\mathrm{CH}_{2}\right)_{9}, \mathrm{R}^{\prime}=\mathrm{H}$

Reagents and Conditions: (a) Diethylphosphonoacetic acid, HOBt, EDCI, DCM:DMF, rt, 16hrs; (b) TMSBr, DCM, then $95 \% \mathrm{EtOH}$.

\section{Scheme 3.5: Synthesis of Acylsulfamates and Acylsulfamides}

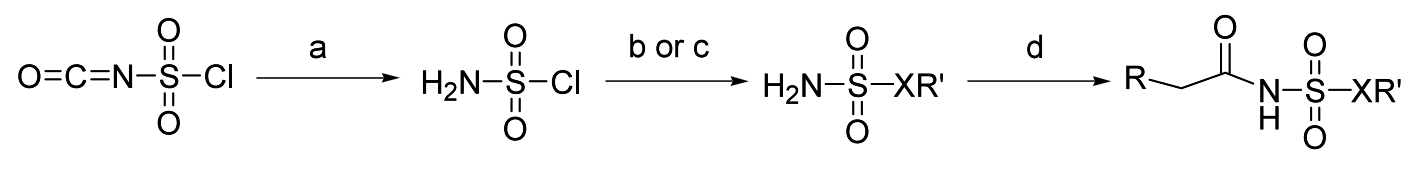

3.15

3.16

3.17a-d

3.19a-d

3.18a,b

$3.20 a, b$

3.17a, $X=O, R^{\prime}=E t ; 3.17 b, X=O \quad R^{\prime}=B u ; 3.17 c, d, X=O, R^{\prime}=4-O M e P h ; 3.18 a, b, X=N H, R^{\prime}=\operatorname{Pr}, 3.19 a, X=O, R^{\prime}=E t$, $\mathrm{R}=\mathrm{CH}_{3}\left(\mathrm{CH}_{2}\right)_{14} ; 3.19 \mathrm{~b}, \mathrm{X}=\mathrm{O} \mathrm{R}^{\prime}=\mathrm{Bu}, \mathrm{R}=\mathrm{CH}_{3}\left(\mathrm{CH}_{2}\right)_{14} ; 3.19 \mathrm{c}, \mathrm{X}=\mathrm{O}, \mathrm{R}^{\prime}=4-\mathrm{OMePh}, \mathrm{R}=\mathrm{CH}_{3}\left(\mathrm{CH}_{2}\right)_{14} ; 3.19 \mathrm{~d}, \mathrm{X}=\mathrm{O}$,

$\mathrm{R}^{\prime}=4-\mathrm{OMePh}, \mathrm{R}=\mathrm{Ph}\left(\mathrm{CH}_{2}\right)_{3} ; 3.20 \mathrm{a}, \mathrm{X}=\mathrm{NH}, \mathrm{R}^{\prime}=\mathrm{Pr}, \mathrm{R}=\mathrm{CH}_{3}\left(\mathrm{CH}_{2}\right)_{14} ; 3.20 \mathrm{~b}, \mathrm{X}=\mathrm{NH}, \mathrm{R}^{\prime}=\mathrm{Pr}, \mathrm{R}=\mathrm{CH}_{3}\left(\mathrm{CH}_{2}\right)_{7} \mathrm{CH}=\mathrm{CH}\left(\mathrm{CH}_{2}\right)_{7}$

Reagents and Conditions: (a) $\mathrm{HCO}_{2} \mathrm{H}$, neat; (b) R'OH, DMA; (c) $\mathrm{R}^{\prime} \mathrm{NH}_{2}$, neat, $\mathrm{NaOH}$; (d) RCOCl, DMAP, $\mathrm{NEt}_{3}$, DCM:DMF. 
Table 3.1: Enzyme Activity of Acylphosphate Mimics

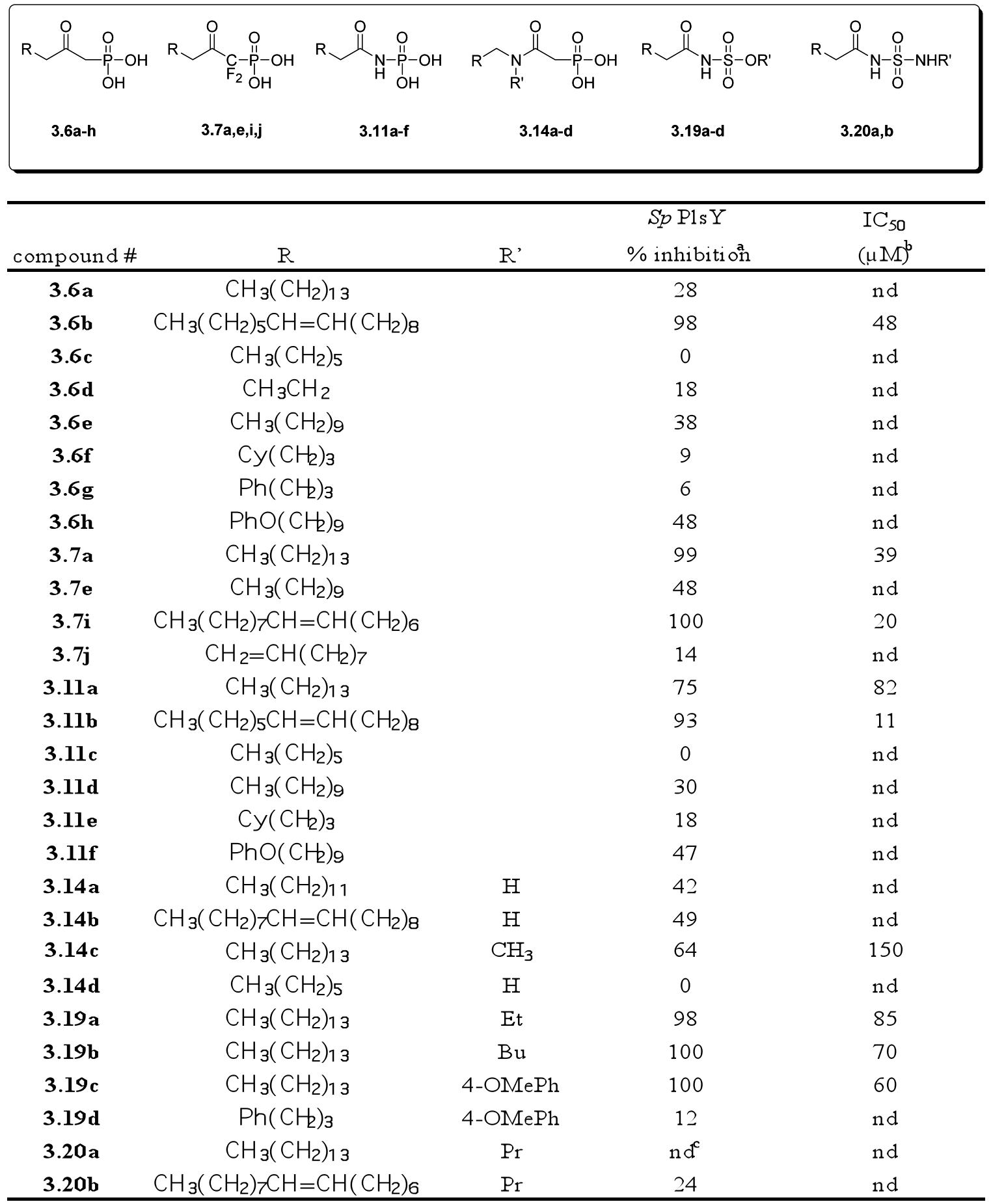

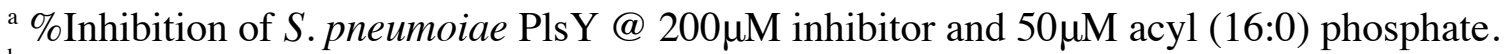

${ }^{\mathrm{b}} \mathrm{IC}_{50}$ were only determined on compounds for which there was greater than $50 \%$ inhibition at $\mathrm{SpPlsY} .{ }^{\mathrm{c}} \mathrm{nd}=$ not determined. 
natural substrate. Unsaturated C18 derivatives showed significant inhibitory activity, which is expected based on initial results observed on the fatty acids incorporated in the 1-position of G3P. ${ }^{153}$ The most active compounds were acylphosphonate $\mathbf{3 . 6} \mathbf{b}$ (IC $_{50} 48$ $\left.\mu \mathrm{M}, \mathrm{C} 18_{\Delta 11}\right), \alpha, \alpha$-difluoromethyl phosphonates 3.7a $\left(\mathrm{IC}_{50} 39 \mu \mathrm{M}, \mathrm{C} 16\right)$ and 3.7i $\left(\mathrm{IC}_{50} 20\right.$ $\left.\mu \mathrm{M}, \mathrm{C} 18_{\Delta 9}\right)$, and acylphosphoramide $\mathbf{3 . 1 1 b}\left(\mathrm{IC}_{50} 11 \mu \mathrm{M}, \mathrm{C} 18_{\Delta 11}\right)$. In contrast, the long chain reverse amide phosphonates $3.14 a-c$ had moderate activity against $S p P l s Y$. The acylsulfamates 3.19a-c had good activity against $S p P l s Y\left(\mathrm{IC}_{50} 85 \mu \mathrm{M}, 70 \mu \mathrm{M}\right.$, and 60 $\mu \mathrm{M}$, respectively); however, acylsulfamide 3.20b was considerably less potent. Kinetic analyses of the acyl- $\mathrm{PO}_{4}$ bioisosteres were performed which determined that these compounds act as competitive inhibitors of $\mathrm{SpPlsY}$ with respect to the acyl- $\mathrm{PO}_{4}$ (Figure 3.4).

The antimicrobial activity for the compound series was tested against a clinicallyrelevant panel of bacteria consisting of $S$. pneumoniae, E. faecalis, Methicillin resistant $S$. aureus, B. subtilis, and B. anthracis (Table 3.2). Activity was weak to moderate against all Gram-positive species tested except for the B. anthracis Sterne strain, which was potently inhibited by acylphosphonates 3.6a (MIC $1.56 \mu \mathrm{g} / \mathrm{mL}$ ) and 3.6b (MIC 0.05 $\mu \mathrm{g} / \mathrm{mL}$ ) and reverse amide phosphonates 3.14a (MIC $0.1 \mu \mathrm{g} / \mathrm{mL}$ ), 3.14b (MIC 0.1 $\mu \mathrm{g} / \mathrm{mL}$ ), and 3.14c (MIC $3.13 \mu \mathrm{g} / \mathrm{mL}$ ). Acylsulfamate 3.19c displayed considerable antibacterial activity against $B$. anthracis and $B$. subtilis (MIC $3.13 \mu \mathrm{g} / \mathrm{mL}$, respectively) with some activity against $S$. pneumoniae (MIC $12.5 \mu \mathrm{g} / \mathrm{mL}$ ). The SAR of compounds exhibiting activity against $B$. anthracis generally correlated with inhibition data against the $S p P$ PlsY enzyme, and together revealed that the most active acylphosphonate and reverse amide phosphonate compounds had longer alkyl chains. The acylphosphoramide and acyl $\alpha, \alpha$-difluormethyl phosphonate series were generally inactive, which may be attributed to a chemical instability and increased acidity of the phosphoramides and difluormethylphosphonates respectively, preventing entry into the cell. None of the compounds tested exhibited antimicrobial activity against Gram-negative species, E. coli and $P$. aeruginosa $(<200 \mu \mathrm{g} / \mathrm{mL})$. Cytotoxicity against mammalian epithelial cells was also evaluated for the most active compounds (Table 3.2). Compounds 3.6a, 3.6b, 3.14a and 3.14b only exhibited cytotoxicity at high concentrations, producing high selectivity indices (Cytoxicity $\mathrm{IC}_{50} /$ B. anthracis MIC) ranging from 2200-4850.

The discovery of the potent antimicrobial activity against $B$. anthracis sparked further studies of the PlsX/PlsY pathway in this bacterium. We initially questioned the nature of B. anthracis or the strain (Sterne) used versus the other Gram-positive bacteria in our panel. Indeed, a potential explanation for species selectivity was the capsule deficient status of the attenuated $B$. anthracis Sterne strain, which might enable better penetration of the compounds into its cells. ${ }^{168}$ In contrast, poor penetration into the other Gram-positive species that likely carry competent capsules may explain the inactivity. In order to explore this relationship we contacted Dr. Vicki Luna at the University of South Florida who has a significant background in $B$. anthracis and other bacillus species. ${ }^{169,170}$ Her lab was able to test our compounds against a panel of $B$. anthracis and closely related B. cereus strains (Tables 3.3 and 3.4). Interestingly, acylphosphonates 3.6a,b and reverse amide phosphonates 3.14a-c showed potent anti-cereus activity across most of the strains tested. Likewise, similar inhibitory activity for capsule-positive and deficient strains of 


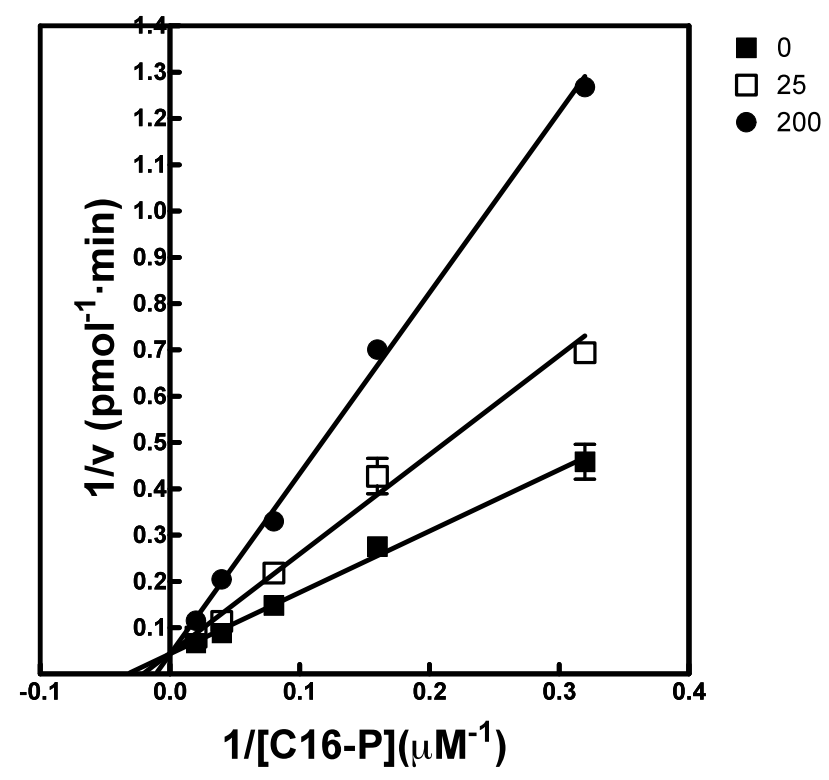

Figure 3.4: Enzyme Kinetics Profile for 3.11b 
Table 3.2: Antimicrobial Activity of Acylphosphate Mimetics against a Panel of Gram-Positive Bacteria.

\begin{tabular}{|c|c|c|c|c|c|c|}
\hline \multirow[b]{2}{*}{ compound \# } & \multirow[b]{2}{*}{ SP } & \multicolumn{4}{|c|}{$\mathrm{MIC}\left(\mathrm{ug} / \mathrm{ml}^{\mathrm{a}}\right)$} & \multirow{2}{*}{$\begin{array}{l}\text { Cytotox } \\
\left(\mu \mathrm{g} / \mathrm{ml}^{\mathrm{l}}\right)\end{array}$} \\
\hline & & $\mathrm{EF}$ & MRSA & $\mathrm{BS}$ & $\mathrm{BA}$ & \\
\hline $3.6 \mathrm{a}$ & 200 & 12.5 & 100 & 25 & 1.56 & 205 \\
\hline $3.6 \mathrm{~b}$ & 200 & 12.5 & 100 & 25 & 0.05 & 235 \\
\hline $3.6 \mathrm{c}$ & $>200$ & $>200$ & 200 & $>200$ & $>200$ & $n d^{c}$ \\
\hline $3.6 \mathrm{~d}$ & 200 & $>200$ & $>200$ & $>200$ & 100 & nd \\
\hline $3.6 \mathrm{e}$ & 25 & 25 & 100 & $>200$ & 50 & 114 \\
\hline $3.6 \mathrm{f}$ & $>200$ & $>200$ & $>200$ & 25 & 200 & nd \\
\hline $3.6 \mathrm{~g}$ & $>200$ & $>200$ & $>200$ & $>200$ & $>200$ & nd \\
\hline $3.6 \mathrm{~h}$ & 50 & 50 & 100 & $>200$ & $>200$ & 34 \\
\hline $3.7 \mathrm{a}$ & $>200$ & 100 & 100 & 200 & 200 & nd \\
\hline $3.7 \mathrm{e}$ & $>200$ & 100 & $>200$ & $>200$ & 200 & nd \\
\hline $3.7 \mathrm{i}$ & $>200$ & 6.25 & $>200$ & $>200$ & 25 & nd \\
\hline $3.7 \mathbf{j}$ & $>200$ & $>200$ & $>200$ & 200 & $>200$ & nd \\
\hline $3.11 \mathrm{a}$ & 100 & 200 & 200 & $>200$ & $>200$ & nd \\
\hline $3.11 b$ & $>200$ & 200 & 200 & 100 & 100 & 46 \\
\hline $3.11 \mathrm{c}$ & $>200$ & $>200$ & $>200$ & $>200$ & $>200$ & nd \\
\hline $3.11 d$ & 100 & 200 & 200 & $>200$ & $>200$ & nd \\
\hline $3.11 \mathrm{e}$ & 200 & $>200$ & $>200$ & $>200$ & $>200$ & nd \\
\hline $3.11 f$ & 100 & 100 & 100 & $>200$ & $>200$ & nd \\
\hline $3.14 \mathrm{a}$ & 200 & $>200$ & 50 & 50 & 0.1 & 220 \\
\hline $3.14 \mathrm{~b}$ & $>200$ & 50 & 100 & 200 & 0.1 & 485 \\
\hline $3.14 c$ & $>200$ & 200 & 200 & $>200$ & 3.13 & 35 \\
\hline $3.14 \mathrm{~d}$ & $>200$ & $>200$ & $>200$ & $>200$ & 100 & 43 \\
\hline $3.19 \mathrm{a}$ & 12.5 & $>200$ & $>200$ & $>200$ & $>200$ & nd \\
\hline $3.19 \mathrm{~b}$ & 25 & $>200$ & $>200$ & $>200$ & $>200$ & nd \\
\hline $3.19 c$ & 12.5 & $>200$ & $>200$ & 3.12 & 3.12 & nd \\
\hline $3.19 \mathrm{~d}$ & 200 & $>200$ & $>200$ & 200 & 200 & nd \\
\hline $3.20 \mathrm{a}$ & $>200$ & $>200$ & $>200$ & 200 & $>200$ & nd \\
\hline $3.20 \mathrm{~b}$ & $>200$ & $>200$ & $>200$ & $>200$ & $>200$ & nd \\
\hline
\end{tabular}

${ }^{a}$ Whole-cell Minimum Inhibitory Concentration of the following species: SPStreptococcus pneumoniae DAW30, EF-Enterococcus faecalis ATCC33186, MRSAMethicillin resistant Staphylococcus aureus ATCC33591, BS-Bacillus subtilis ATCC 23857 , and BA-Bacillus anthracis Sterne $34 \mathrm{~F} 2 .{ }^{\mathrm{b}}$ Doxycycline $\left(\mathrm{IC}_{50}=212 \mu \mathrm{g} / \mathrm{mL}\right)$ was used as a control. Assays were performed using the Vero monkey kidney cell line (CCL81). ${ }^{\mathrm{c}}$ nd $=$ not determined. 
Table 3.3: Antimicrobial Activity of Acylphosphate Mimics against a Panel of Bacillus cereus Strains

\begin{tabular}{cccccccc}
\hline & \multicolumn{7}{c}{$\mathrm{MIC} \mu \mathrm{g} / \mathrm{mL}^{\mathbf{a}}$} \\
\cline { 2 - 7 } compound \# & $\mathrm{BC}(40)$ & $\mathrm{BC}(104)$ & $\mathrm{BC}(169)^{\mathbf{b}}$ & $\mathrm{BC}(174)$ & $\mathrm{BC}(210)$ & $\mathrm{BC}(508)$ & $\mathrm{BC}(1056)$ \\
\hline $\mathbf{3 . 6 a}$ & $>200$ & 50 & $>200$ & $>200$ & 0.001 & 1.56 & 0.05 \\
$\mathbf{3 . 6 b}$ & $>200$ & 12.5 & $>200$ & $>200$ & 0.05 & $>200$ & 0.2 \\
$\mathbf{3 . 6 c}$ & $>200$ & $>200$ & $>200$ & 200 & $>200$ & $>200$ & 200 \\
$\mathbf{3 . 6 d}$ & $>200$ & $>200$ & $>200$ & $>200$ & $>200$ & $>200$ & $>200$ \\
$\mathbf{3 . 6 e}$ & $>200$ & 100 & $>200$ & $>200$ & 100 & $>200$ & 100 \\
$\mathbf{3 . 6 f}$ & $>200$ & $>200$ & $>200$ & $>200$ & $>200$ & $>200$ & $>200$ \\
$\mathbf{3 . 6 g}$ & $>200$ & $>200$ & $>200$ & $>200$ & $>200$ & $>200$ & $>200$ \\
$\mathbf{3 . 6 h}$ & $>200$ & $>200$ & $>200$ & $>200$ & $>200$ & $>200$ & $>200$ \\
$\mathbf{3 . 7 a}$ & $>200$ & 200 & 200 & 200 & $>200$ & 200 & 200 \\
$\mathbf{3 . 7 e}$ & $>200$ & $>200$ & $>200$ & $>200$ & $>200$ & $>200$ & 200 \\
$\mathbf{3 . 7 i}$ & $>200$ & $>200$ & $>200$ & $>200$ & $>200$ & $>200$ & 200 \\
$\mathbf{3 . 7 j}$ & $>200$ & $>200$ & $>200$ & $>200$ & $>200$ & $>200$ & $>200$ \\
$\mathbf{3 . 1 1 a}$ & $>200$ & $>200$ & $>200$ & $>200$ & $>200$ & $>200$ & $>200$ \\
$\mathbf{3 . 1 1 b}$ & $>200$ & $>200$ & $>200$ & $>200$ & 200 & 200 & 200 \\
$\mathbf{3 . 1 1} \mathbf{3 . 1 1}$ & $>200$ & $>200$ & $>200$ & $>200$ & $>200$ & $>200$ & $>200$ \\
$\mathbf{3 . 1 1 d}$ & 200 & $>200$ & $>200$ & 100 & 200 & 100 & 200 \\
$\mathbf{3 . 1 1} \mathbf{3}$ & $>200$ & $>200$ & $>200$ & $>200$ & $>200$ & $>200$ & 200 \\
$\mathbf{3 . 1 1 f}$ & $>200$ & $>200$ & 200 & $>200$ & $>200$ & $>200$ & $>200$ \\
$\mathbf{3 . 1 4 a}$ & 3.13 & 0.8 & $>200$ & 0.8 & 200 & 0.4 & 3.13 \\
$\mathbf{3 . 1 4 b}$ & 3.13 & 6.25 & 0.8 & 3.13 & 1.56 & 6.25 & 0.8 \\
$\mathbf{3 . 1 4 c}$ & 0.024 & 0.001 & 0.024 & 0.2 & 0.1 & 0.05 & 0.024 \\
$\mathbf{3 . 1 4 d}$ & $>200$ & $>200$ & $>200$ & $>200$ & $>200$ & $>200$ & $>200$ \\
\hline
\end{tabular}

${ }^{a}$ Whole-cell Minimum Inhibitory Concentration of varying strains of Bacillus cereus.

${ }^{\mathrm{b}}$ Capsule-deficient strain of B. cereus. 
Table 3.4: Antimicrobial Activity against a Panel of Bacillus anthracis Strains

\begin{tabular}{|c|c|c|c|c|c|c|c|c|c|c|c|c|c|}
\hline \multirow[b]{2}{*}{ Cmpd\# } & \multicolumn{13}{|c|}{$\operatorname{MIC}(\mu \mathrm{g} / \mathrm{mL})^{\mathrm{a}}$} \\
\hline & $\begin{array}{c}\text { Ames } \\
\text { (F1a) }\end{array}$ & $\begin{array}{c}\text { Ames } \\
\text { (NR-411) }\end{array}$ & Davis & Kruger & V770NR32 & $107 N R 33$ & $116 \mathrm{NR} 34$ & $\begin{array}{r}\mathrm{N} 105^{\mathrm{b}} \\
(2-9)\end{array}$ & $\begin{array}{l}\text { N105 } \\
(2-11) \\
\end{array}$ & $\begin{array}{c}\text { N105 } \\
(22-12) \\
\end{array}$ & $\begin{array}{c}\text { French } \\
\text { (B2) }\end{array}$ & Vollum & WNA \\
\hline $3.6 \mathrm{a}$ & 0.195 & 0.39 & 0.097 & 0.012 & 0.097 & 0.097 & 0.195 & 50 & 0.049 & 0.049 & 12.5 & 0.097 & 50 \\
\hline $3.6 \mathrm{~b}$ & 3.13 & 0.39 & 0.195 & 0.097 & 0.097 & 0.097 & 0.024 & 50 & 0.049 & 0.049 & 25 & 0.097 & 50 \\
\hline $3.6 \mathrm{c}$ & 200 & $>200$ & 200 & 200 & 200 & 200 & 200 & 200 & 200 & $>200$ & $>200$ & $>200$ & 100 \\
\hline $3.6 \mathrm{~d}$ & $>200$ & $>200$ & 200 & 200 & 200 & 200 & 200 & $>200$ & 200 & $>200$ & $>200$ & $>200$ & 200 \\
\hline $3.6 \mathrm{e}$ & 200 & $>200$ & $>200$ & 200 & 100 & $>200$ & 100 & $>200$ & 100 & $>200$ & $>200$ & 200 & $>200$ \\
\hline $3.6 f$ & 200 & 200 & $>200$ & 200 & 100 & 50 & $>200$ & 100 & 200 & $>200$ & $>200$ & $>200$ & $>200$ \\
\hline $3.6 \mathrm{~g}$ & $>200$ & 200 & $>200$ & 200 & $>200$ & 200 & $>200$ & $>200$ & $>200$ & $>200$ & $>200$ & 200 & $>200$ \\
\hline $3.6 \mathrm{~h}$ & $>200$ & $>200$ & $>200$ & $>200$ & $>200$ & 200 & $>200$ & $>200$ & $>200$ & $>200$ & $>200$ & $>200$ & $>200$ \\
\hline $3.7 \mathrm{a}$ & 200 & 200 & 200 & 200 & 200 & 200 & 200 & 200 & 200 & 100 & $>200$ & $>200$ & 200 \\
\hline $3.7 \mathrm{e}$ & 25 & $>200$ & $>200$ & $>200$ & $>200$ & $>200$ & $>200$ & $>200$ & $>200$ & $>200$ & $>200$ & $>200$ & 200 \\
\hline $3.7 \mathrm{i}$ & $>200$ & $>200$ & $>200$ & $>200$ & $>200$ & 200 & $>200$ & 100 & $>200$ & $>200$ & $>200$ & $>200$ & 200 \\
\hline 3.7j & $>200$ & $>200$ & $>200$ & $>200$ & 200 & 200 & $>200$ & 100 & $>200$ & $>200$ & $>200$ & $>200$ & 200 \\
\hline $3.11 \mathrm{a}$ & $>200$ & $>200$ & $>200$ & $>200$ & $>200$ & $>200$ & $>200$ & 50 & $>200$ & 200 & $>200$ & $>200$ & $>200$ \\
\hline $3.11 \mathrm{~b}$ & $>200$ & $>200$ & $>200$ & $>200$ & 50 & $>200$ & $>200$ & 50 & $>200$ & $>200$ & 200 & $>200$ & $>200$ \\
\hline $3.11 \mathrm{c}$ & $>200$ & $>200$ & $>200$ & 200 & $>200$ & 200 & $>200$ & $>200$ & $>200$ & $>200$ & 200 & $>200$ & $>200$ \\
\hline $3.11 d$ & 200 & 200 & $>200$ & 200 & 200 & 200 & 200 & 200 & 200 & $>200$ & $>200$ & 200 & 200 \\
\hline $3.11 \mathrm{e}$ & $>200$ & 200 & $>200$ & $>200$ & 200 & 100 & 200 & 200 & 200 & 100 & $>200$ & $>200$ & 200 \\
\hline $3.11 \mathrm{f}$ & $>200$ & $>200$ & $>200$ & $>200$ & 200 & 100 & $>200$ & 200 & 200 & 50 & $>200$ & $>200$ & $>200$ \\
\hline $3.14 a$ & 0.78 & 6.25 & 1.56 & 0.195 & 1.56 & 0.39 & 0.049 & 0.097 & 0.097 & 0.049 & 0.78 & 1.56 & 1.56 \\
\hline $3.14 b$ & 0.78 & 3.13 & 1.56 & 3.13 & 3.13 & 0.78 & 0.39 & 3.13 & 0.097 & 0.097 & 1.56 & 0.39 & 1.56 \\
\hline $3.14 \mathrm{c}$ & 0.049 & 0.78 & 1.56 & 0.097 & 0.049 & 0.049 & 0.049 & 3.13 & 0.097 & 0.097 & 0.39 & 0.097 & 0.097 \\
\hline $3.14 d$ & $>200$ & $>200$ & $>200$ & $>200$ & 200 & $>200$ & 200 & $>200$ & $>200$ & 100 & 100 & 50 & 100 \\
\hline
\end{tabular}

${ }^{a}$ Whole-cell Minimum Inhibitory Concentration in $\mu \mathrm{g} / \mathrm{ml}$ of varying strains of Bacillus Anthracis. Penicillin ( $\mathrm{MIC}=0.008-0.03 \mu \mathrm{g} / \mathrm{ml})$ and Ciprofloxacin $(\mathrm{MIC}=0.03$ $0.06 \mu \mathrm{g} / \mathrm{ml}$ ) were used as controls. ${ }^{\mathrm{b}}$ Capsule-deficient strain. 
B. anthracis was seen with some strains showing low MICs confirming our initial results and showing that these compounds possess significant activity against clinically relevant B. anthracis strains. However, these data demonstrated that the anti-anthracis activity seen was independent of the presence of the capsule.

Our second idea questioned the uniqueness of the PlsX/PlsY pathway in $B$. anthracis. This idea was supported by an analysis from our collaborators at St. Jude Children's Research Hospital of the B. anthracis genome showing that it has three putative $p l_{s} Y$ genes. This finding is unusual because most bacteria ( $\left.>99 \%\right)$ posses only a single $p l_{s} Y$ gene. Several bacillus species harbor multiple PlsY isoforms. $B$. licheniformis, $B$. thuringinesis, $B$. cereus, and $B$. clausii have two homologs, whereas $B$. subtilis has only a single PlsY. To date, all three $p l s Y$ homolgs from $B$. anthracis have been purified following cloning and expression. A comparative analysis of the protein sequences of $B$. subtilis PlsY (BsPlsY) and the three BaPlsYs have been performed. This indicated that $B a \mathrm{P} 1 s \mathrm{Y} 1$ and $B a \mathrm{PlsY} 2$ are similar to $B s \mathrm{PlsY}$ and other prototypical PlsYs with $62 \%$ and $53 \%$ sequence identity, respectively. The $B a \mathrm{PlsY} 3$ is the most different. It has $92 \%$ sequence similarity to the $B c \mathrm{PlsY} 2$ but these are not related to any other PlsY isoforms. $B c \mathrm{PlsY} 1$ and $B a \mathrm{PlsY} 1$ are $97 \%$ identical which may explain the similarities in antimicrobial activity seen in the two species. $B a \mathrm{PlsY} 1$ was tested for its acyltransferase activity using one of our potent inhibitors 3.9e comparing it to that of $S p \mathrm{PlsY}$. We have discovered that this enzyme is indeed an acyl-PO $\mathrm{P}_{4}: \mathrm{G} 3 \mathrm{P}$ acyltransferase showing $\mathrm{BaPlsY} 1$ inhibitory activity. Comparison of enzyme inhibition activity of $\mathrm{SpPlsY}$ and $\mathrm{BaPlsY} 1$ of our compound library is listed in Table 3.5. There are considerable differences in activity for some compounds, but the acylsulfamates and acylsulfamamides have similar activity against the two PlsY enzymes. There is ongoing work to determine if the other two pls $Y$ genes also encode glycerol-phosphate acyltransferases or some other acyltransferase activity. Determining the specific roles of the three BaPlsY enzymes would give us insight in to which enzyme is essential to phospholipid biosynthesis as it would be the target for the design of selective inhibitors for future antimicrobial drug discovery.

\section{Conclusions}

Substrate mimics incorporating six acyl- $\mathrm{PO}_{4}$ bioisosteric head groups have been synthesized. Based on the preliminary SAR, longer chain analogues matching the substrate were the most active in each series. Kinetic profiles show that these compounds are acting competitively at PlsY. Acylphosphonates 3.6a-b, reverse amide phosphonates 3.14a-c, and acylsulfamate 3.19c show promise as early leads in the development of potential novel antimicrobial agents demonstrating good target enzyme inhibition, good antimicrobial activity against $B$. anthracis, and low cytotoxicity. Even though these compounds showed significant activity against at $S p P l s Y$, overall antimicrobial activity was generally weak or nonexistent with only a few compounds having MIC's of $12.5 \mu \mathrm{g} / \mathrm{mL}$ (acylsulfamates 3.19a and 3.19c). A possible explanation for this activity could be lack of cell penetration due to chemical instability or increased acidity of the compounds in the library. Overall, we've discovered the first known inhibitors of the Gram-positive PlsX/PlsY pathway to phosphatidic acid. 
Table 3.5: Comparison of Inhibitory Activity for $\mathrm{SpPIsY}$ and BaPIsY1

\begin{tabular}{|c|c|c|}
\hline compound \# & $\begin{array}{c}S p \text { P1sY } \\
\% \text { inhibition } \\
\end{array}$ & $\begin{array}{c}\text { Ba P1sY1 } \\
\% \text { inhibition }\end{array}$ \\
\hline $3.6 \mathrm{a}$ & 28 & 67 \\
\hline $3.6 \mathrm{~b}$ & 98 & 40 \\
\hline $3.6 \mathrm{c}$ & 0 & 0 \\
\hline $3.6 \mathrm{~d}$ & 18 & 0 \\
\hline $3.6 \mathrm{e}$ & 38 & 28 \\
\hline $3.6 \mathrm{f}$ & 9 & $n d^{c}$ \\
\hline $3.6 \mathrm{~g}$ & 6 & 0 \\
\hline $3.6 \mathrm{~h}$ & 48 & 55 \\
\hline $3.7 \mathrm{a}$ & 99 & 62 \\
\hline $3.7 \mathrm{e}$ & 48 & 23 \\
\hline $3.7 \mathrm{i}$ & 100 & 8 \\
\hline $3.7 \mathbf{j}$ & 14 & 91 \\
\hline $3.11 \mathrm{a}$ & 75 & 33 \\
\hline $3.11 \mathrm{~b}$ & 93 & 41 \\
\hline $3.11 \mathrm{c}$ & 0 & 0 \\
\hline $3.11 \mathrm{~d}$ & 30 & 26 \\
\hline $3.11 \mathrm{e}$ & 18 & 0 \\
\hline $3.11 f$ & 47 & 30 \\
\hline $3.14 \mathrm{a}$ & 42 & 27 \\
\hline $3.14 \mathrm{~b}$ & 49 & 100 \\
\hline $3.14 c$ & 64 & 68 \\
\hline $3.14 d$ & 0 & 29 \\
\hline $3.19 \mathrm{a}$ & 98 & 99 \\
\hline $3.19 \mathrm{~b}$ & 100 & 99 \\
\hline $3.19 c$ & 100 & 100 \\
\hline $3.19 \mathrm{~d}$ & 12 & 13 \\
\hline $3.20 \mathrm{a}$ & nd & nd \\
\hline $3.20 \mathrm{~b}$ & 24 & 56 \\
\hline
\end{tabular}

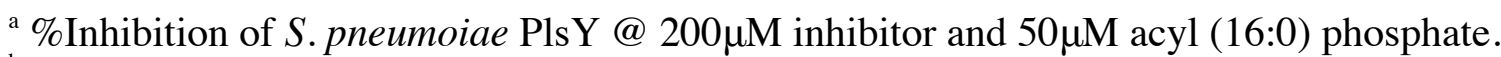

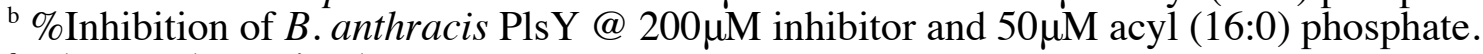

${ }^{\mathrm{c}}$ nd $=$ not determined. 


\section{Experimental Section}

Chemistry

All reagents and anhydrous solvents were purchased from Sigma-Aldrich. All the reagent-grade solvents used for chromatography were purchased from Fisher Scientific (Suwanee, GA) and flash column chromatography silica cartridges were obtained from Biotage Inc. (Lake Forest, VA). The reactions were monitored by thin-layer chromatography (TLC) on pre-coated Merck 60 F254 silica gel plates and visualized using UV light (254 nm) and Iodine staining. A Biotage FLASH column chromatography system was used to purify the reaction mixtures. All $1 \mathrm{H}$ and 13C NMR spectra were recorded on a Varian INOVA-500 spectrometer. Chemical shifts $(\delta)$ are reported in ppm relative to the residual solvent peak or internal standard (tetramethylsilane), and coupling constants $(J)$ are reported in hertz $(\mathrm{Hz})$. Mass spectra were recorded on a Bruker Esquire LCMS using ESI. The yields quoted are unoptimized. Purity of the final products were analyzed by a Waters Acquity UPLC-PDA-ELSD-MS. UPLC separations were performed using an Acquity UPLC 2.1 x $50 \mathrm{~mm}$ BEH C18 column (1.7 um, Waters) at $50^{\circ} \mathrm{C}$, and a $1.0 \mathrm{~mL} / \mathrm{min}$ flow rate. The PDA was set to acquire UV data from $210-400$ $\mathrm{nm}$ throughout the run. UPLC1: Gradient: solvent A (10 $\mathrm{mM}$ ammonium acetate in water) and solvent $\mathrm{B}(10 \mathrm{mM}$ ammonium acetate in acetonitrile): $0-0.2 \mathrm{~min} 10-30 \% \mathrm{~B}$, $0.20-1.40 \mathrm{~min} 30-95 \% \mathrm{~B}$ (linear gradient), $1.40-1.70 \mathrm{~min} 95 \% \mathrm{~B}, 1.70-1.75 \mathrm{~min} 10 \% \mathrm{~B}$. UPLC2: Gradient: solvent A (10 mM ammonium acetate in water) and solvent B (10 mM ammonium acetate in acetonitrile): 0 - $0.2 \min 10-30 \% \mathrm{~B}, 0.20-1.40 \mathrm{~min} 30-95 \% \mathrm{~B}$ (linear gradient), $1.40-2.70 \min 95 \% \mathrm{~B}, 2.70-2.75 \mathrm{~min} 10 \% \mathrm{~B}$.

Synthesis of monopalmitoyl phosphate (3.2). Silver phosphate (376 mg, $0.90 \mathrm{mmol})$ was added to anhydrous phosphoric acid $(199 \mathrm{mg}, 2.03 \mathrm{mmol})$ in diethyl ether $(10 \mathrm{~mL})$, and the mixture was stirred at room temperature for $16 \mathrm{hr}$. Palmitoyl chloride $(558 \mathrm{mg}$, $2.03 \mathrm{mmol})$ was dissolved in diethyl ether $(5 \mathrm{ml})$ and added dropwise to the resulting mixture. After the addition was complete, the mixture was stirred for an additional hour. The resulting mixture was filtered, and the solid was washed with diethyl ether. The filtrate and washings were combined and concentrated in vacuo. Recrystallization of the resulting residue from warm benzene yielded monopalmitoyl phosphate as a white powder (24\%). ${ }^{1} \mathrm{HNMR}(\mathrm{MeOD}, 300 \mathrm{MHz}), \delta 0.92(\mathrm{t}, 3 \mathrm{H}, J=6.0 \mathrm{~Hz}), 1.31$ (bs, $\left.26 \mathrm{H}\right)$, $1.65(\mathrm{~m}, 2 \mathrm{H}), 2.46(\mathrm{t}, 2 \mathrm{H}, J=7.0 \mathrm{~Hz}) .{ }^{13} \mathrm{CNMR}(\mathrm{MeOD}, 300 \mathrm{MHz}), \delta 12.5,21.8,23.6$, 28.6, 28.7, 28.8, 31.1, 34.0, 168.3. MS(ESI), $\mathrm{m} / \mathrm{z}=335(\mathrm{M}-\mathrm{H})^{-}$.

General procedure for synthesis of acylphosphonate esters (3.4a-h). A 1.6M solution of $n$-Butyl lithium $(3.5 \mathrm{eq})$ in hexanes was added to THF at $-78^{\circ} \mathrm{C}$. After stirring for $30 \mathrm{~min}$, dimethyl methanephosphonate (3.5 eq) was added drop-wise to the mixture over 30 min generating the carbanion. After the resulting suspension was stirred for an additional $30 \mathrm{~min}$, various esters or acid chlorides (1.0 eq) in THF were added drop-wise over $30 \mathrm{~min}$. The resulting suspension was allowed to stir until the temperature rose to $20^{\circ} \mathrm{C}$. The reaction mix was quenched with glacial acetic acid $(3 \mathrm{~mL})$ until mildly acidic $(\mathrm{pH}=5)$. The reaction mix was extracted with ethyl acetate. The organic layer was 
washed with brine, dried over $\mathrm{Na}_{2} \mathrm{SO}_{4}$, and then concentrated in vacuo. Flash column purification (0-100\%, Petroleum Ether/Ethyl Acetate) yielded the corresponding acylphosphonate esters.

Dimethyl 2-oxoheptadecylphosphonate (3.4a). Using the above general procedure, $n$ butyl lithium $(32.0 \mathrm{mmol})$, dimethyl methanephosphonate $(32.0 \mathrm{mmol})$, methylpalmitate (9.24 mmol) and THF (45 mL) were used to synthesize 3.4a as a white solid $(89 \%), \mathrm{mp}=$ $47-49^{\circ} \mathrm{C}$. TLC $R_{f}=0.5$ (Ethyl Acetate). ${ }^{1} \mathrm{H}$ NMR $\left(\mathrm{CDCl}_{3}, 500 \mathrm{MHz}\right): \delta 0.90(\mathrm{t}, 3 \mathrm{H}, J=$ $6.5 \mathrm{~Hz}), 1.27-1.33$ (bs, 24H), $1.60(\mathrm{~m}, 2 \mathrm{H}), 2.63(\mathrm{t}, 2 \mathrm{H}, J=7.0 \mathrm{~Hz}), 3.11(\mathrm{~d}, 2 \mathrm{H}, J=23.0$ $\mathrm{Hz}), 3.80$ (s, 3H), 3.82 (s, 3H). MS(ESI), m/z = 385.9 [M+Na] $]^{+}, 361.3[\mathrm{M}-\mathrm{H}]^{-}$.

(Z)-dimethyl 2-oxononadec-12-enylphosphonate (3.4b). Using the above general procedure, $n$-butyl lithium $(3.5 \mathrm{mmol})$, dimethyl methanephosphonate $(3.5 \mathrm{mmol})$, vaccenoyl chloride $(1.0 \mathrm{mmol})$ and THF $(15 \mathrm{~mL})$ were used to synthesize $\mathbf{3 . 4 b}$ as a colorless waxy solid (77\%). TLC $R_{f}=0.5$ (Ethyl Acetate). ${ }^{1} \mathrm{H}$ NMR $\left(\mathrm{CDCl}_{3}, 500 \mathrm{MHz}\right)$ : $\delta 0.81(\mathrm{t}, 3 \mathrm{H}, J=7.0 \mathrm{~Hz}), 1.24(\mathrm{bs}, 20 \mathrm{H}), 1.50(\mathrm{~m}, 2 \mathrm{H}), 1.94(\mathrm{q}, 4 \mathrm{H}, J=8.5 \mathrm{~Hz}), 2.53(\mathrm{t}$, $2 \mathrm{H}, J=7.5 \mathrm{~Hz}), 3.01(\mathrm{~d}, 2 \mathrm{H}, J=22.5 \mathrm{~Hz}), 3.71(\mathrm{~s}, 3 \mathrm{H}), 3.73(\mathrm{~s}, 3 \mathrm{H}), 5.28(\mathrm{~m}, 2 \mathrm{H})$. $\mathrm{MS}(\mathrm{ESI}), \mathrm{m} / \mathrm{z}=411.4[\mathrm{M}+\mathrm{Na}]+, 387.1[\mathrm{M}-\mathrm{H}]^{-}$.

Dimethyl 2-oxononylphosphonate (3.4c). Using the above general procedure, $n$-butyl lithium (32.0 mmol), dimethyl methanephosphonate $(32.0 \mathrm{mmol})$, methyl octanoate $(9.24$ $\mathrm{mmol})$ and THF $(40 \mathrm{~mL})$ were used to synthesize $3.4 \mathrm{c}$ as a colorless oil $(14 \%)$. TLC $R_{f}=$ 0.5 (Ethyl Acetate). ${ }^{1} \mathrm{H}$ NMR $\left(\mathrm{CDCl}_{3}, 500 \mathrm{MHz}\right): \delta 0.89(\mathrm{t}, 3 \mathrm{H}, J=7.0 \mathrm{~Hz}), 1.30(\mathrm{bs}$, $8 \mathrm{H}), 1.60(\mathrm{~m}, 2 \mathrm{H}), 2.62(\mathrm{t}, 2 \mathrm{H}, J=7.5 \mathrm{~Hz}), 3.11(\mathrm{~d}, 2 \mathrm{H}, J=23.0 \mathrm{~Hz}), 3.80(\mathrm{~m}, 3 \mathrm{H}), 3.82$ $(\mathrm{m}, 3 \mathrm{H}) . \mathrm{MS}(\mathrm{ESI}), \mathrm{m} / \mathrm{z}=273.1[\mathrm{M}+\mathrm{Na}]+$.

Dimethyl 2-oxopentylphosphonate (3.4d). Using the above general procedure, $n$-butyl lithium (17.5 mmol), dimethyl methanephosphonate (17.5 mmol), methyl butyrate $(5.0$ $\mathrm{mmol})$ and THF $(25 \mathrm{~mL})$ were used to synthesize $3.4 \mathrm{~d}$ as a colorless oil $(76 \%)$. TLC $R_{f}=$ 0.2 (Ethyl Acetate). ${ }^{1} \mathrm{H}$ NMR $\left(\mathrm{CDCl}_{3}, 500 \mathrm{MHz}\right): \delta 0.93(\mathrm{t}, 3 \mathrm{H}, J=7.5 \mathrm{~Hz}), 1.62(\mathrm{~m}$, $2 \mathrm{H}), 2.60(\mathrm{t}, 2 \mathrm{H}, J=7.0 \mathrm{~Hz}), 3.08(\mathrm{~d}, 2 \mathrm{H}, J=22.5 \mathrm{~Hz}), 3.78(\mathrm{~s}, 3 \mathrm{H}), 3.80(\mathrm{~s}, 3 \mathrm{H})$. $\mathrm{MS}(\mathrm{ESI}), \mathrm{m} / \mathrm{z}=217.0[\mathrm{M}+\mathrm{Na}]+192.70[\mathrm{M}-\mathrm{H}]^{-}$.

Dimethyl 2-oxotridecylphosphonate (3.4e). Using the above general procedure, $n$-butyl lithium (17.5 mmol), dimethyl methanephosphonate $(17.5 \mathrm{mmol})$, methyl laurate $(5.0$ $\mathrm{mmol})$ and THF $(25 \mathrm{~mL})$ were used to synthesize $3.4 \mathrm{e}$ as a white solid $(73 \%)$. TLC $R_{f}=$ 0.4 (Ethyl Acetate). ${ }^{1} \mathrm{H}$ NMR $\left(\mathrm{CDCl}_{3}, 500 \mathrm{MHz}\right): \delta 0.88(\mathrm{t}, 3 \mathrm{H}, J=7.0 \mathrm{~Hz}), 1.25$ (bs, $16 \mathrm{H}), 1.59(\mathrm{~m}, 2 \mathrm{H}), 2.61(\mathrm{t}, 2 \mathrm{H}, J=7.0 \mathrm{~Hz}), 3.08(\mathrm{~d}, 2 \mathrm{H}, J=22.5 \mathrm{~Hz}), 3.78(\mathrm{~s}, 3 \mathrm{H}), 3.80$ (s, 3H). MS(ESI), m/z = 329.3 [M+Na], $305.0[\mathrm{M}-\mathrm{H}]^{-}$.

Dimethyl 6-cyclohexyl-2-oxohexylphosphonate (3.4f). Using the above general procedure, $n$-butyl 1 lithium $(17.5 \mathrm{mmol})$, dimethyl methanephosphonate $(17.5 \mathrm{mmol})$, cyclohexanepentanoyl chloride $(5.0 \mathrm{mmol})$ and THF $(25 \mathrm{~mL})$ were used to synthesize 3.4f as a colorless oil (67\%). TLC $R_{f}=0.4$ (Ethyl Acetate). ${ }^{1} \mathrm{H} \mathrm{NMR}\left(\mathrm{CDCl}_{3}, 500 \mathrm{MHz}\right)$ : $\delta 0.85(\mathrm{~m}, 2 \mathrm{H}), 1.11-1.32(\mathrm{~m}, 6 \mathrm{H}), 1.53-1.68(\mathrm{~m}, 10 \mathrm{H}), 2.61(\mathrm{t}, 2 \mathrm{H}, J=7.0 \mathrm{~Hz}), 3.08(\mathrm{~d}$, 
$2 \mathrm{H}, J=23.0 \mathrm{~Hz}), 3.78(\mathrm{~s}, 3 \mathrm{H}), 3.80(\mathrm{~s}, 3 \mathrm{H}) . \mathrm{MS}(\mathrm{ESI}), \mathrm{m} / \mathrm{z}=313.10[\mathrm{M}+\mathrm{Na}]^{+}, 288.9$ $[\mathrm{M}-\mathrm{H}]^{-}$.

Dimethyl 2-oxo-6-phenylhexylphosphonate (3.4g). Using the above general procedure, $n$-butyl lithium (17.5 mmol), dimethyl methanephosphonate $(17.5 \mathrm{mmol}), 5$ phenylpentanoyl chloride $(5.0 \mathrm{mmol})$ and THF $(25 \mathrm{~mL})$ were used to synthesize $\mathbf{3 . 4 g}$ as a colorless oil (62\%). TLC $R_{f}=0.5$ (Ethyl Acetate). ${ }^{1} \mathrm{H}$ NMR $\left(\mathrm{CDCl}_{3}, 500 \mathrm{MHz}\right): \delta 1.63$ $(\mathrm{m}, 4 \mathrm{H}), 2.63(\mathrm{~m}, 4 \mathrm{H}), 3.07(\mathrm{~d}, 2 \mathrm{H}, J=22.5 \mathrm{~Hz}), 3.77(\mathrm{~s}, 3 \mathrm{H}), 3.79(\mathrm{~s}, 3 \mathrm{H}), 7.16(\mathrm{~d}, 2 \mathrm{H}, J$ $=8.0 \mathrm{~Hz}), 7.17(\mathrm{t}, 1 \mathrm{H}, J=7.5 \mathrm{~Hz}), 7.27(\mathrm{t}, 2 \mathrm{H}, J=8.0 \mathrm{~Hz}) . \mathrm{MS}(\mathrm{ESI}), \mathrm{m} / \mathrm{z}=307.10$ $[\mathrm{M}+\mathrm{Na}]^{+}, 282.90[\mathrm{M}-\mathrm{H}]^{-}$.

Dimethyl 2-oxo-12-phenoxydodecylphosphonate (3.4h). Using the above general procedure, $n$-butyl lithium (17.5 mmol), dimethyl methanephosphonate (17.5 mmol), 11 phenoxyundecanoyl chloride $(5.0 \mathrm{mmol})$ and THF $(25 \mathrm{~mL})$ were used to synthesize $\mathbf{3 . 4 h}$ as a white solid (66\%). TLC $R_{f}=0.6$ (Ethyl Acetate). ${ }^{1} \mathrm{H}$ NMR $\left(\mathrm{CDCl}_{3}, 500 \mathrm{MHz}\right): \delta$ $1.28(\mathrm{bs} 10 \mathrm{H}), 1.45(\mathrm{~m}, 2 \mathrm{H}), 1.58(\mathrm{~m}, 2 \mathrm{H}), 1.77(\mathrm{~m}, 2 \mathrm{H}), 2.61(\mathrm{t}, 2 \mathrm{H}, J=7.0 \mathrm{~Hz}), 3.08(\mathrm{~d}$, $2 \mathrm{H}, J=22.5 \mathrm{~Hz}), 3.78(\mathrm{~s}, 3 \mathrm{H}), 3.80(\mathrm{~s}, 3 \mathrm{H}), 3.95(\mathrm{t}, 2 \mathrm{H}, J=6.5 \mathrm{~Hz}), 6.89(\mathrm{~d}, 2 \mathrm{H}, J=$ $8.0 \mathrm{~Hz}), 6.92(\mathrm{t}, 1 \mathrm{H}, J=7.5 \mathrm{~Hz}), 7.27(\mathrm{t}, 2 \mathrm{H}, J=7.0 \mathrm{~Hz}) . \mathrm{MS}(\mathrm{ESI}), \mathrm{m} / \mathrm{z}=407.30$ $[\mathrm{M}+\mathrm{Na}]^{+}, 382.90[\mathrm{M}-\mathrm{H}]^{-}$.

General procedure for synthesis of acyl $\alpha, \alpha$-difluoromethyl phosphonate esters (3.5a,e,i,j). A freshly prepared solution of LDA $(2.0$ eq) was added to THF $(20 \mathrm{~mL})$ at $78^{\circ} \mathrm{C}$. After stirring for $30 \mathrm{~min}$, diethyl $\alpha, \alpha$-difluoromethyl phosphonate $(2.0 \mathrm{eq})$ in THF $(1 \mathrm{~mL})$ was added drop-wise to the mixture over $10 \mathrm{~min}$ to generate the carbanion. After the resulting suspension was stirred for an additional $45 \mathrm{~min}$, various esters or acid chlorides $(1.0 \mathrm{eq})$ in THF $(5 \mathrm{~mL})$ were added drop-wise over $10 \mathrm{~min}$. The resulting suspension was allowed to stir for $2.5 \mathrm{~h}$. After the reaction was complete, it was quenched with glacial acetic acid $(2 \mathrm{~mL})$ followed by saturated ammonium chloride. The mixture was allowed to warm to room temperature and extracted with chloroform. The organic extracts were washed with brine, dried over $\mathrm{Na}_{2} \mathrm{SO}_{4}$, and then concentrated in vacuo. Flash column purification (0-100\%, Petroleum Ether/Ethyl Acetate) yielded the desired acyl $\alpha, \alpha$-difluoromethyl phosphonate esters.

Diethyl 1,1-difluoro-2-oxoheptadecylphosphonic acid (3.5a). Using the above general procedure, $n$-butyl lithium $(4.25 \mathrm{mmol})$, diisopropylamine $(4.25 \mathrm{mmol})$, diethyl $\alpha, \alpha$ difluromethyl phosphonate $(4.25 \mathrm{mmol})$, methylpalmitate $(2.13 \mathrm{mmol})$ and THF $(30 \mathrm{~mL})$ were used to synthesize 3.5a as a colorless oil (55\%). TLC $R_{f}=0.5$ (8:2, Pet Ether:EtOAc). ${ }^{1} \mathrm{H}$ NMR $\left(\mathrm{CDCl}_{3}, 500 \mathrm{MHz}\right): \delta 0.89$ (t, 3H, $\left.J=7.0 \mathrm{~Hz}\right), 1.25$ (bs, 24H), $1.39(\mathrm{t}, 6 \mathrm{H}, J=7.0 \mathrm{~Hz}), 1.63(\mathrm{~m}, 2 \mathrm{H}), 2.77(\mathrm{t}, 2 \mathrm{H}, J=7.5 \mathrm{~Hz}), 4.31(\mathrm{~m}, 4 \mathrm{H}) . \mathrm{MS}(\mathrm{ESI})$, $\mathrm{m} / \mathrm{z}=449.4[\mathrm{M}+\mathrm{Na}]^{+}, 425.1[\mathrm{M}-\mathrm{H}]^{-}$.

Diethyl 1,1-difluoro-2-oxotridecylphosphonic acid (3.5e): Using the above general procedure, $n$-butyl lithium $(6.0 \mathrm{mmol})$, diisopropylamine $(6.0 \mathrm{mmol})$, diethyl $\alpha, \alpha$ difluromethyl phosphonate $(6.0 \mathrm{mmol})$, methyl laurate $(2.0 \mathrm{mmol})$ and THF $(30 \mathrm{~mL})$ were used to synthesize 3.5e as a colorless oil (69\%). TLC $R_{f}=0.6$ (8:2, Pet Ether:EtOAc). ${ }^{1} \mathrm{H}$ NMR $\left(\mathrm{CDCl}_{3}, 300 \mathrm{MHz}\right): \delta 0.90(\mathrm{t}, 3 \mathrm{H}, J=6.8 \mathrm{~Hz}), 1.28(\mathrm{bs}, 16 \mathrm{H})$, 
$1.41(\mathrm{t}, 6 \mathrm{H}, J=6.0 \mathrm{~Hz}), 1.65(\mathrm{~m}, 2 \mathrm{H}), 2.79(\mathrm{t}, 2 \mathrm{H}, J=7.2 \mathrm{~Hz}), 4.33(\mathrm{~m}, 4 \mathrm{H}) . \quad \mathrm{MS}(\mathrm{ESI})$, $\mathrm{m} / \mathrm{z}=393.3[\mathrm{M}+\mathrm{Na}]^{+}$.

Diethyl (Z)-1,1-difluoro-2-oxononadec-10-enylphosphonic acid (3.5i). Using the above general procedure, $n$-butyl lithium $(6.0 \mathrm{mmol})$, diisopropylamine $(6.0 \mathrm{mmol})$, diethyl $\alpha, \alpha$-difluromethyl phosphonate $(6.0 \mathrm{mmol})$, methyl oleate $(2.0 \mathrm{mmol})$ and THF (30 mL) were used to synthesize $3.5 \mathbf{i}$ as a colorless oil (78\%). TLC $R_{f}=0.5$ (8:2, Pet Ether:EtOAc). ${ }^{1} \mathrm{H} \mathrm{NMR}\left(\mathrm{CDCl}_{3}, 500 \mathrm{MHz}\right): \delta 0.88(\mathrm{t}, 3 \mathrm{H}, J=6.5 \mathrm{~Hz}), 1.29(\mathrm{bd}, 20 \mathrm{H})$, $1.39(\mathrm{t}, 6 \mathrm{H}, J=7.0 \mathrm{~Hz}), 1.64(\mathrm{~m}, 2 \mathrm{H}), 2.01(\mathrm{q}, 4 \mathrm{H}, J=5.0 \mathrm{~Hz}), 2.77(\mathrm{t}, 2 \mathrm{H}, J=7.0 \mathrm{~Hz})$, $4.31(\mathrm{~m}, 4 \mathrm{H}), 4.34(\mathrm{~m}, 2 \mathrm{H}) . \mathrm{MS}(\mathrm{ESI}), \mathrm{m} / \mathrm{z}=475.3[\mathrm{M}+\mathrm{Na}]^{+}$.

Diethyl 1,1-difluoro-2-oxododec-11-enylphosphonic acid (3.5j): Using the above general procedure, $n$-butyl lithium $(6.0 \mathrm{mmol})$, diisopropylamine $(6.0 \mathrm{mmol})$, diethyl $\alpha, \alpha$ difluromethyl phosphonate $(6.0 \mathrm{mmol})$, methyl 10 -undecanoate $(2.0 \mathrm{mmol})$ and THF (30 $\mathrm{mL}$ ) were used to synthesize $\mathbf{3 . 5} \mathbf{j}$ as a colorless oil (39\%). TLC $R_{f}=0.5$ (8:2, Pet Ether:EtOAc). ${ }^{1} \mathrm{H} \mathrm{NMR}\left(\mathrm{CDCl}_{3}, 500 \mathrm{MHz}\right): \delta 1.29$ (bs, $\left.10 \mathrm{H}\right), 1.40$ (t. $\left.6 \mathrm{H}, J=7.0 \mathrm{~Hz}\right)$, $1.64(\mathrm{~m}, 2 \mathrm{H}), 2.04(\mathrm{q}, 2 \mathrm{H}, J=5.0 \mathrm{~Hz}), 2.78(\mathrm{t}, 2 \mathrm{H}, J=7.0 \mathrm{~Hz}), 4.31(\mathrm{~m}, 4 \mathrm{H}), 4.97(\mathrm{dd}$, $2 \mathrm{H}, J=20 \mathrm{~Hz}, 30 \mathrm{~Hz}), 5.81(\mathrm{~m}, 1 \mathrm{H}) . \mathrm{MS}(\mathrm{ESI}), \mathrm{m} / \mathrm{z}=377.2[\mathrm{M}+\mathrm{Na}]^{+}$.

General procedure for synthesis of acylphosphoramidate esters (3.10a-f). Various esters or acids (1.0 eq) were treated with $\mathrm{KOH}(1.0 \mathrm{eq})$ in $\mathrm{H}_{2} \mathrm{O}: \mathrm{ACN}(1: 1)$. The reaction mixture was stirred and heated at $110^{\circ} \mathrm{C}$ until dry, then subjected to high vacuum for $16 \mathrm{~h}$. DCM $(25 \mathrm{~mL})$ was added to the flask. To the resulting suspension was added ethylchloroformate $(1.0 \mathrm{eq})$ which was stirred for $7 \mathrm{~h}$, then chilled to $\quad-78^{\circ} \mathrm{C}$. Pretreatment of diethyl phosphoramidate (3.2 eq) with $1.6 \mathrm{M} n$-butyl lithium (3.2 eq) to generate the anion was performed before slow addition to the activated acyl species. The reaction was allowed to stir until the temperature rose to $25^{\circ} \mathrm{C}$. The reaction mixture was quenched with glacial acetic acid $(3 \mathrm{~mL})$ until mildly acidic $(\mathrm{pH}=5)$. The reaction mix was extracted with ethyl acetate. The organic layer was washed with brine, dried over $\mathrm{Na}_{2} \mathrm{SO}_{4}$, and then concentrated in vacuo. Flash column purification (0-100\%, Petroleum Ether/Ethyl Acetate) yielded the desired acylphosphoramide esters.

(Diethyl) 1-oxohexadecylphosphoramidate (3.10a). Using the above general procedure, methylpalmitate $(10.0 \mathrm{mmol}), \mathrm{ACN}: \mathrm{H}_{2} \mathrm{O}(20 \mathrm{~mL}), \mathrm{KOH}(10.0 \mathrm{mmol})$, ethyl chloroformate $(10.0 \mathrm{mmol}), n$-butyl lithium $(35.0 \mathrm{mmol})$, and diethyl phosphoramidate $(35.0 \mathrm{mmol})$ were used to synthesize 3.10a as a white solid $(25 \%), \mathrm{mp}=53-56^{\circ} \mathrm{C}$. TLC $R_{f}=0.6$ (Ethyl Acetate). ${ }^{1} \mathrm{H}$ NMR $\left(\mathrm{CDCl}_{3}, 500 \mathrm{MHz}\right): \delta 0.90(\mathrm{t}, 3 \mathrm{H}, J=6.5 \mathrm{~Hz}), 1.27$ (bs, 24H) $1.38(\mathrm{t}, 6 \mathrm{H}, J=7.0 \mathrm{~Hz}), 1.65(\mathrm{~m}, 2 \mathrm{H}), 2.36(\mathrm{t}, 2 \mathrm{H}, J=7.0 \mathrm{~Hz}), 4.22(\mathrm{~m}, 4 \mathrm{H})$, $8.34(\mathrm{~s}, 1 \mathrm{H}) . \mathrm{MS}(\mathrm{ESI}), \mathrm{m} / \mathrm{z}=390.1[\mathrm{M}-\mathrm{H}]^{-}$.

(Diethyl) (Z)-1-oxooctadec-11-enylphosphoramidate (3.10b). Using the above general procedure, vaccenic acid (1.0 mmol), $\mathrm{ACN}: \mathrm{H}_{2} \mathrm{O}(10 \mathrm{~mL}), \mathrm{KOH}(1.0 \mathrm{mmol})$, ethyl chloroformate $(1.0 \mathrm{mmol}), n$-butyl lithium $(3.5 \mathrm{mmol})$, and diethyl phosphoramidate $(3.5$ mmol) were used to synthesize $\mathbf{3 . 1 0 b}$ as a yellow syrup (20\%). TLC $R_{f}=0.5$ (Ethyl Acetate). ${ }^{1} \mathrm{H} \mathrm{NMR}\left(\mathrm{CDCl}_{3}, 500 \mathrm{MHz}\right): \delta 0.91$ (t, 3H, $\left.J=7.0 \mathrm{~Hz}\right), 1.30-1.37(\mathrm{bs}, 20 \mathrm{H})$, 
$1.40(\mathrm{t}, 6 \mathrm{H}, J=7.0 \mathrm{~Hz}), 1.60(\mathrm{~m}, 2 \mathrm{H}), 2.04(\mathrm{q}, 4 \mathrm{H}, J=8.5 \mathrm{~Hz}), 2.37(\mathrm{t}, 2 \mathrm{H}, J=8.0 \mathrm{~Hz})$, $4.23(\mathrm{~m}, 4 \mathrm{H}), 5.38(\mathrm{~m}, 2 \mathrm{H})$. MS (ESI), $\mathrm{m} / \mathrm{z}=416.1[\mathrm{M}-\mathrm{H}]^{-}$.

(Diethyl) 1-oxooctylphosphoramidate (3.10c). Using the above general procedure, methyl caprylate $(5.0 \mathrm{mmol}), \mathrm{ACN}: \mathrm{H}_{2} \mathrm{O}(20 \mathrm{~mL}), \mathrm{KOH}(5.0 \mathrm{mmol})$, ethyl chloroformate (5.0 mmol), $n$-butyl lithium (17.5 mmol), and diethyl phosphoramidate (17.5 mmol) were used to synthesize 3.10c as a colorless oil (32\%). TLC $R_{f}=0.3$ (Ethyl Acetate). ${ }^{1} \mathrm{H}$ NMR $\left(\mathrm{CDCl}_{3}, 500 \mathrm{MHz}\right): \delta 0.90(\mathrm{t}, 3 \mathrm{H}, J=7.5 \mathrm{~Hz}), 1.31(\mathrm{bs}, 8 \mathrm{H}) 1.39(\mathrm{t}, 6 \mathrm{H}, J=7.5$ $\mathrm{Hz}), 1.66(\mathrm{~m}, 2 \mathrm{H}), 2.37(\mathrm{t}, 2 \mathrm{H}, J=7.5 \mathrm{~Hz}), 4.21(\mathrm{~m}, 4 \mathrm{H}) . \quad \mathrm{MS}(\mathrm{ESI}), \mathrm{m} / \mathrm{z}=277.9[\mathrm{M}-\mathrm{H}]^{-}$ , $302.2[\mathrm{M}+\mathrm{Na}]^{+}$.

(Diethyl) 1-oxododecylphosphoramidate (3.10d). Using the above general procedure, methyl laurate $(5.0 \mathrm{mmol}), \mathrm{ACN}: \mathrm{H}_{2} \mathrm{O}(20 \mathrm{~mL}), \mathrm{KOH}(5.0 \mathrm{mmol})$, ethyl chloroformate (5.0 mmol), $n$-butyl lithium (17.5 mmol), and diethyl phosphoramidate $(17.5 \mathrm{mmol})$ were used to synthesize 3.10d as a white solid (10\%). TLC $R_{f}=0.5$ (Ethyl Acetate). ${ }^{1} \mathrm{H}$ NMR $\left(\mathrm{CDCl}_{3}, 500 \mathrm{MHz}\right): \delta 0.85(\mathrm{t}, 3 \mathrm{H}, J=6.5 \mathrm{~Hz}), 1.23(\mathrm{bs}, 16 \mathrm{H}), 1.33(\mathrm{t}, 6 \mathrm{H}, J=7.0$ $\mathrm{Hz}), 1.61(\mathrm{~m}, 2 \mathrm{H}), 2.33$ (t, 2H, $J=7.5 \mathrm{~Hz}), 4.16(\mathrm{~m}, 4 \mathrm{H}) . \mathrm{MS}(\mathrm{ESI}), \mathrm{m} / \mathrm{z}=334.1[\mathrm{M}-\mathrm{H}]^{-}$, $358.3[\mathrm{M}+\mathrm{Na}]^{+}$.

(Diethyl) 5-cyclohexyl-1-oxopentylphosphoramidate (3.10e). Using the above general procedure, 5-phenylvaleric acid $(5.0 \mathrm{mmol}), \mathrm{ACN}: \mathrm{H}_{2} \mathrm{O}(20 \mathrm{~mL}), \mathrm{KOH}(5.0 \mathrm{mmol})$, ethyl chloroformate $(5.0 \mathrm{mmol}), n$-butyl lithium $(17.5 \mathrm{mmol})$, and diethyl phosphoramidate $(17.5 \mathrm{mmol})$ were used to synthesize 3.10e as a white solid $(35 \%)$. TLC $R_{f}=0.6$ (Ethyl Acetate). ${ }^{1} \mathrm{H}$ NMR $\left(\mathrm{CDCl}_{3}, 500 \mathrm{MHz}\right): \delta 0.85(\mathrm{~m}, 2 \mathrm{H}), 1.11-1.33(\mathrm{~m}, 8 \mathrm{H}), 1.36(\mathrm{t}, 6 \mathrm{H}, J$ $=7.0 \mathrm{~Hz}), 1.58-1.69(\mathrm{~m}, 8 \mathrm{H}), 2.34(\mathrm{t}, 2 \mathrm{H}, J=7.5 \mathrm{~Hz}), 4.20(\mathrm{~m}, 4 \mathrm{H}) . \mathrm{MS}(\mathrm{ESI}), \mathrm{m} / \mathrm{z}=$ $342.2[\mathrm{M}+\mathrm{Na}]^{+}, 318.0[\mathrm{M}-\mathrm{H}]^{-}$.

(Diethyl) 1-oxo-11-phenoxyundecylphosphoramidate (3.10f). Using the above general procedure, 11-phenoxyundecanoic acid (5.0 mmol), $\mathrm{ACN}: \mathrm{H}_{2} \mathrm{O}(20 \mathrm{~mL}), \mathrm{KOH}(5.0$ mmol), ethyl chloroformate $(5.0 \mathrm{mmol}), n$-butyl lithium $(17.5 \mathrm{mmol})$, and diethyl phosphoramidate $(17.5 \mathrm{mmol})$ were used to synthesize $\mathbf{3 . 1 0 f}$ as a white solid $(15 \%)$. TLC $R_{f}=0.6$ (Ethyl Acetate). ${ }^{1} \mathrm{H} \mathrm{NMR}\left(\mathrm{CDCl}_{3}, 500 \mathrm{MHz}\right): \delta 1.30(\mathrm{bs}, 10 \mathrm{H}), 1.36(\mathrm{t}, 6 \mathrm{H}$, $J=7.5 \mathrm{~Hz}), 1.45(\mathrm{~m}, 2 \mathrm{H}), 1.63(\mathrm{~m}, 2 \mathrm{H}), 1.77(\mathrm{~m}, 2 \mathrm{H}), 2.34(\mathrm{t}, 2 \mathrm{H}, J=7.5 \mathrm{~Hz}), 3.95(\mathrm{t}$, $2 \mathrm{H}, J=7.0 \mathrm{~Hz}), 4.20(\mathrm{~m}, 4 \mathrm{H}), 6.89(\mathrm{~d}, 2 \mathrm{H}, J=8.0 \mathrm{~Hz}), 6.92(\mathrm{t}, 1 \mathrm{H}, J=7.0 \mathrm{~Hz}), 7.27(\mathrm{t}$, $2 \mathrm{H}, J=7.5 \mathrm{~Hz}) . \mathrm{MS}(\mathrm{ESI}), \mathrm{m} / \mathrm{z}=436.3[\mathrm{M}+\mathrm{Na}]^{+}, 412.1[\mathrm{M}-\mathrm{H}]^{-}$.

General procedure for synthesis of acyl reverse amide phosphonate esters (3.13a-d). To DCM/DMF (1:1) was added HOBt (1.0 eq), diethylphosphonoacetic acid (1.0 eq), and EDCI $(1.0 \mathrm{eq})$. The mixture was allowed to stir for $30 \mathrm{~min}$. Drop-wise various amines (1.0 eq) were added. The reaction mixture was allowed to stir at room temperature for 16h. The mixture was extracted with chloroform. The organic layer was washed with $\mathrm{NaHCO}_{3}$, water, and brine, then dried over $\mathrm{Na}_{2} \mathrm{SO}_{4}$, and concentrated in vacuo. Flash column purification (0-100\%, Petroleum Ether/Ethyl Acetate) yielded the desired reverse amide phosphonate esters. 
Diethyl (Tetradecylcarbamoyl)methylphosphonic acid (3.13a). Using the above general procedure, HOBt $(5.0 \mathrm{mmol})$, EDCI $(5.0 \mathrm{mmol})$, diethylphosphonoaceticacid (5.0 $\mathrm{mmol}), \mathrm{DCM} / \mathrm{DMF}(50 \mathrm{~mL})$, and tetradecylamine $(5.0 \mathrm{mmol})$ were used to synthesize 3.13a as a yellow solid $(29 \%), \mathrm{mp}=32-34^{\circ} \mathrm{C}$. TLC $R_{f}=0.3$ (Ethyl Acetate). ${ }^{1} \mathrm{H}$ NMR $\left(\mathrm{CDCl}_{3}, 500 \mathrm{MHz}\right): \delta 0.84(\mathrm{t}, 3 \mathrm{H}, J=6.5 \mathrm{~Hz}), 1.22(\mathrm{bs}, 22 \mathrm{H}) 1.31(\mathrm{t}, 6 \mathrm{H}, J=7.0 \mathrm{~Hz})$, $1.47(\mathrm{~m}, 2 \mathrm{H}), 2.82(\mathrm{~d}, 2 \mathrm{H}, J=20.5 \mathrm{~Hz}), 3.21(\mathrm{q}, 2 \mathrm{H}, J=6.5 \mathrm{~Hz}), 4.11(\mathrm{~m}, 4 \mathrm{H}), 6.91(\mathrm{bt}$, 1H) $\mathrm{MS}(\mathrm{ESI}), \mathrm{m} / \mathrm{z}=390.1[\mathrm{M}-\mathrm{H}]^{-}, \mathrm{m} / \mathrm{z}=414.4[\mathrm{M}+\mathrm{Na}]^{+}$.

Diethyl ((Z)-octadec-9-enylcarbamoyl)methylphosphonic acid (3.13b). Using the above general procedure, HOBt $(5.0 \mathrm{mmol})$, EDCI $(5.0 \mathrm{mmol})$, diethylphosphonoacetic acid $(5.0 \mathrm{mmol}), \mathrm{DCM} / \mathrm{DMF}(50 \mathrm{~mL})$, and oleylamine $(5.0 \mathrm{mmol})$ were used to synthesize 3.13b as a colorless oil (18\%). TLC $R_{f}=0.3$ (Ethyl Acetate). ${ }^{1} \mathrm{H}$ NMR $\left(\mathrm{CDCl}_{3}, 500 \mathrm{MHz}\right): \delta 0.88(\mathrm{t}, 3 \mathrm{H}, J=6.5 \mathrm{~Hz}), 1.27(\mathrm{bs}, 22 \mathrm{H}), 1.34(\mathrm{t}, 6 \mathrm{H}, J=7.0 \mathrm{~Hz})$, $1.51(\mathrm{~m}, 2 \mathrm{H}), 2.01(\mathrm{~m}, 4 \mathrm{H}), 2.83(\mathrm{~d}, 2 \mathrm{H}, J=22.0 \mathrm{~Hz}), 3.26(\mathrm{t}, 2 \mathrm{H}, J=7.5 \mathrm{~Hz}), 4.14(\mathrm{~m}$, $4 \mathrm{H}), 5.35(\mathrm{~m}, 2 \mathrm{H}), 6.73(\mathrm{bt}, 1 \mathrm{H}) . \mathrm{MS}(\mathrm{ESI}), \mathrm{m} / \mathrm{z}=444.1[\mathrm{M}-\mathrm{H}]^{-}, \mathrm{m} / \mathrm{z}=468.3[\mathrm{M}+\mathrm{Na}]^{+}$.

Diethyl (N-dodecyl-N-methylcarbamoyl)methylphosphonic acid (3.13c). Using the above general procedure, HOBt $(5.0 \mathrm{mmol})$, EDCI (5.0 mmol), diethylphosphonoacetic acid $(5.0 \mathrm{mmol}), \mathrm{DCM} / \mathrm{DMF}(50 \mathrm{~mL})$, and $\mathrm{N}$-methyl dodecylamine $(5.0 \mathrm{mmol})$ were used to synthesize 3.13c as a colorless oil (18\%). TLC $R_{f}=0.2$ (Ethyl Acetate). ${ }^{1} \mathrm{H}$ NMR $\left(\mathrm{CDCl}_{3}, 500 \mathrm{MHz}\right): \delta 0.88(\mathrm{t}, 3 \mathrm{H}, J=6.5 \mathrm{~Hz}), 1.26(\mathrm{bs}, 18 \mathrm{H}), 1.34(\mathrm{t}, 6 \mathrm{H}, J=7.5 \mathrm{~Hz})$, $1.52(\mathrm{~m}, 2 \mathrm{H}), 3.04(\mathrm{~d}, 2 \mathrm{H}, J=22.5 \mathrm{~Hz}), 3.01(\mathrm{bd}, 3 \mathrm{H}), 3.37(\mathrm{t}, 2 \mathrm{H}, J=7.5 \mathrm{~Hz}), 4.18(\mathrm{~m}$, 4H). $\mathrm{MS}(\mathrm{ESI}), \mathrm{m} / \mathrm{z}=376.1[\mathrm{M}-\mathrm{H}]^{-}, \mathrm{m} / \mathrm{z}=400.4[\mathrm{M}+\mathrm{Na}]^{+}$.

Diethyl (Heptylcarbamoyl)methylphosphonic acid (3.13d). Using the above general procedure, HOBt $(5.0 \mathrm{mmol})$, EDCI $(5.0 \mathrm{mmol})$, diethylphosphonoacetic acid (5.0 $\mathrm{mmol}), \mathrm{DCM} / \mathrm{DMF}(50 \mathrm{~mL})$, and heptylamine $(5.0 \mathrm{mmol})$ were used to synthesize $\mathbf{3 . 1 3 d}$ as a colorless oil $(30 \%)$. TLC $R_{f}=0.2$ (Ethyl Acetate). ${ }^{1} \mathrm{H} \mathrm{NMR}\left(\mathrm{CDCl}_{3}, 500 \mathrm{MHz}\right): \delta$ $0.88(\mathrm{t}, 3 \mathrm{H}, J=6.5 \mathrm{~Hz}), 1.26-1.36(\mathrm{~m}, 14 \mathrm{H}) 1.51(\mathrm{~m}, 2 \mathrm{H}), 2.82(\mathrm{~d}, 2 \mathrm{H}, J=20.0 \mathrm{~Hz})$, $3.26(\mathrm{q}, 2 \mathrm{H}, J=6.5 \mathrm{~Hz}), 4.14(\mathrm{~m}, 4 \mathrm{H}), 6.72(\mathrm{bt}, 1 \mathrm{H}) \mathrm{MS}(\mathrm{ESI}), \mathrm{m} / \mathrm{z}=291.1[\mathrm{M}-\mathrm{H}]^{-}, \mathrm{m} / \mathrm{z}$ $=316.1[\mathrm{M}+\mathrm{Na}]^{+}$.

General procedure for ester deprotection (3.6a-h, 3.7a,e,i,j, 3.11a-d, and 3.14a-d). Each ester $(1.0 \mathrm{eq})$ was treated with $2 \mathrm{ml}$ of DCM. The flask was flushed several times with Argon. Bromotrimethylsilane (10.0 eq) was added slowly to the mixture. The resulting solution was allowed to stir $16 \mathrm{~h}$ at ambient temperature. Excess TMSBr was removed in vacuo. $95 \%$ Ethanol $(5 \mathrm{~mL})$ was added to the reaction flask and allowed to stir for $1 \mathrm{~h}$ after which the solvent was removed in vacuo. The residue was triturated several times with diethyl ether and filtered.

2-oxoheptadecylphosphonic acid (3.6a). Using the above general procedure, dimethyl 2-oxoheptadecylphosphonate $(2.76 \mathrm{mmol}), \mathrm{TMSBr}(27.6 \mathrm{mmol})$ and DCM (2 mL) were used to synthesize 3.6a as a white solid $(89 \%$ overall $), \mathrm{mp}=91-93{ }^{\circ} \mathrm{C}$. ${ }^{1} \mathrm{H} \mathrm{NMR}\left(\mathrm{d}_{6}{ }^{-}\right.$ DMSO, 500MHz): $\delta 0.86(\mathrm{t}, 3 \mathrm{H}, J=6.0 \mathrm{~Hz}), 1.25(\mathrm{bs}, 24 \mathrm{H}), 1.43(\mathrm{~m}, 2 \mathrm{H}), 2.57(\mathrm{t}, 2 \mathrm{H}, J$ $=7.0 \mathrm{~Hz}), 2.92(\mathrm{~d}, 2 \mathrm{H}, J=22.5 \mathrm{~Hz}) .{ }^{13} \mathrm{C} \mathrm{NMR}\left(\mathrm{d}_{6}-\mathrm{DMSO}, 500 \mathrm{MHz}\right): \delta 14.4,22.6$, 
23.4, 29.0, 29.2, 29.4, 29.5, 29.6, 31.8, 43.1, 45.1, 46.1. 203.9. $\mathrm{MS}(\mathrm{ESI}), \mathrm{m} / \mathrm{z}=333.4$ $[\mathrm{M}-\mathrm{H}]^{-}$. UPLC1: $t_{\mathrm{R}} 1.18 \mathrm{~min}$, Purity $>99 \%$.

(Z)-2-oxononadec-12-enylphosphonic acid (3.6b). Using the above general procedure, (Z)-dimethyl 2-oxononadec-12-enylphosphonate (0.5 mmol), TMSBr (5.0 mmol) and DCM (2 mL) were used to synthesize 3.6b as a light yellow waxy solid (77\% overall). ${ }^{1} \mathrm{H}$ NMR $\left(\mathrm{CD}_{3} \mathrm{OD}, 500 \mathrm{MHz}\right): \delta 0.93(\mathrm{t}, 3 \mathrm{H}, J=7.0 \mathrm{~Hz}), 1.33(\mathrm{bs}, 20 \mathrm{H}), 1.58(\mathrm{~m}, 2 \mathrm{H})$, $2.05(\mathrm{q}, 4 \mathrm{H}, J=8.5 \mathrm{~Hz}), 2.67(\mathrm{t}, 2 \mathrm{H}, J=7.5 \mathrm{~Hz}), 3.09(\mathrm{~d}, 2 \mathrm{H}, J=22.5 \mathrm{~Hz}), 5.36(\mathrm{~m}, 2 \mathrm{H})$. ${ }^{13} \mathrm{C}$ NMR $\left(\mathrm{CD}_{3} \mathrm{OD}, 500 \mathrm{MHz}\right): \delta 13.1,22.3,23.1,26.8,28.7,28.9,29.2,29.4,29.5,31.5$, 39.0, 43.3, 129.5, 204.1. MS(ESI), $\mathrm{m} / \mathrm{z}=359.2[\mathrm{M}-\mathrm{H}]^{-}$. UPLC1: $t_{\mathrm{R}} 1.25 \mathrm{~min}$, Purity $96 \%$.

2-oxononylphosphonic acid (3.6c). Using the above general procedure, Dimethyl 2oxononylphosphonate $(0.4 \mathrm{mmol}), \mathrm{TMSBr}(4.0 \mathrm{mmol})$ and DCM $(2 \mathrm{~mL})$ were used to synthesize 3.6c as a light yellow oil (14\% overall). ${ }^{1} \mathrm{H}$ NMR $\left(\mathrm{CD}_{3} \mathrm{OD}, 500 \mathrm{MHz}\right): \delta 0.92$ $(\mathrm{t}, 3 \mathrm{H}, J=7.0 \mathrm{~Hz}), 1.32(\mathrm{bs}, 8 \mathrm{H}), 1.58(\mathrm{~m}, 2 \mathrm{H}), 2.67(\mathrm{t}, 2 \mathrm{H}, J=7.0 \mathrm{~Hz}), 3.08(\mathrm{~d}, 2 \mathrm{H}, J=$ $20 \mathrm{~Hz}$ ). ${ }^{13} \mathrm{C}$ NMR (d-MeOD, 500MHz): $\delta$ 13.0, 22.3, 23.1, 28.7, 28.8, 31.5, 43.2, 204.1. MS(ESI), $\mathrm{m} / \mathrm{z}=223.1[\mathrm{M}+\mathrm{H}]^{+}, 221.2[\mathrm{M}-\mathrm{H}]^{-}$. UPLC1: $t_{\mathrm{R}} 0.37 \mathrm{~min}$, Purity $98 \%$.

2-oxopentylphosphonic acid (3.6d). Using the above general procedure, Dimethyl 2oxopentylphosphonate $(2.3 \mathrm{mmol}), \mathrm{TMSBr}(23.0 \mathrm{mmol})$ and DCM $(2 \mathrm{~mL})$ were used to synthesize 3.6d as a yellow oil $(76 \%$ overall $) .{ }^{1} \mathrm{H} \mathrm{NMR}\left(\mathrm{CDCl}_{3}, 500 \mathrm{MHz}\right): \delta 0.91(\mathrm{t}$, $3 \mathrm{H}, J=7.5 \mathrm{~Hz}), 1.59(\mathrm{~m}, 2 \mathrm{H}), 2.62(\mathrm{t}, 2 \mathrm{H}, J=7.0 \mathrm{~Hz}), 3.20(\mathrm{~d}, 2 \mathrm{H}, J=22.5 \mathrm{~Hz}) .{ }^{13} \mathrm{C}$ NMR $\left(\mathrm{CDCl}_{3}, 500 \mathrm{MHz}\right): \delta 13.0,16.6,31.6,43.2,204.0 . \mathrm{MS}(\mathrm{ESI}), \mathrm{m} / \mathrm{z}=167.0[\mathrm{M}+$ $\mathrm{H}]+164.7[\mathrm{M}-\mathrm{H}]^{-}$. UPLC1: $t_{\mathrm{R}} 0.15 \mathrm{~min}$, Purity $>99 \%$.

2-oxotridecylphosphonic acid (3.6e). Using the above general procedure, Dimethyl 2oxotridecylphosphonate (3.0 mmol), TMSBr (30.0 mmol) and DCM (2 mL) were used to synthesize 3.6e as a white solid $(73 \%$ overall $), \mathrm{mp}=81-84^{\circ} \mathrm{C} .{ }^{1} \mathrm{H}$ NMR $\left(\mathrm{CD}_{3} \mathrm{OD}\right.$, $500 \mathrm{MHz}): \delta 0.92(\mathrm{t}, 3 \mathrm{H}, J=6.0 \mathrm{~Hz}), 1.31(\mathrm{bs}, 16 \mathrm{H}), 1.57(\mathrm{~m}, 2 \mathrm{H}), 2.67(\mathrm{t}, 2 \mathrm{H}, J=7.0$ $\mathrm{Hz}), 3.09$ (d, 2H, $J=22.5 \mathrm{~Hz}) .{ }^{13} \mathrm{C} \mathrm{NMR}\left(\mathrm{CD}_{3} \mathrm{OD}, 500 \mathrm{MHz}\right): \delta 13.1,22.4,23.1,28.7$, 29.1, 29.2, 29.3 , 29.4, 31.7, 43.2, 204.1. $\mathrm{MS}(\mathrm{ESI}), \mathrm{m} / \mathrm{z}=279.2[\mathrm{M}+\mathrm{H}]^{+}, 277.0[\mathrm{M}-\mathrm{H}]^{-}$. UPLC1: $t_{\mathrm{R}} 0.73 \mathrm{~min}$, Purity $>99 \%$.

6-cyclohexyl-2-oxohexylphosphonic acid (3.6f). Using the above general procedure, Dimethyl 6-cyclohexyl-2-oxohexylphosphonate (2.7 mmol), TMSBr $(27.0 \mathrm{mmol})$ and $\operatorname{DCM}(2 \mathrm{~mL})$ were used to synthesize 3.6f as a light yellow oil $(69 \%$ overall $) .{ }^{1} \mathrm{H}$ NMR $\left(\mathrm{CDCl}_{3}, 500 \mathrm{MHz}\right): \delta 0.90(\mathrm{~m}, 2 \mathrm{H}), 1.12-1.36(\mathrm{~m}, 6 \mathrm{H}), 1.53-1.68(\mathrm{~m}, 10 \mathrm{H}), 2.69(\mathrm{t}, 2 \mathrm{H}$, $J=7.0 \mathrm{~Hz}), 3.06(\mathrm{~d}, 2 \mathrm{H}, J=23.0 \mathrm{~Hz}) .{ }^{13} \mathrm{C} \mathrm{NMR}\left(\mathrm{CDCl}_{3}, 500 \mathrm{MHz}\right): \delta 23.7,26.2,26.3$, 26.7, 33.3, 37.2 , 37.4, 44.2, 204.6. $\mathrm{MS}(\mathrm{ESI}), \mathrm{m} / \mathrm{z}=260.8[\mathrm{M}-\mathrm{H}]^{-}$. UPLC1: $t_{\mathrm{R}} 0.51 \mathrm{~min}$, Purity $>99 \%$.

2-oxo-6-phenylhexylphosphonic acid (3.6g). Using the above general procedure, Dimethyl 2-oxo-6-phenylhexylphosphonate (2.2 mmol), TMSBr $(22.0 \mathrm{mmol})$ and DCM $(2 \mathrm{~mL})$ were used to synthesize $\mathbf{3 . 6 g}$ as a light yellow oil (62\% overall). ${ }^{1} \mathrm{H}$ NMR $\left(\mathrm{CD}_{3} \mathrm{OD}, 500 \mathrm{MHz}\right): \delta 1.56(\mathrm{~m}, 4 \mathrm{H}), 2.58(\mathrm{~m}, 4 \mathrm{H}), 3.13(\mathrm{~d}, 2 \mathrm{H}, J=22.5 \mathrm{~Hz}), 7.14(\mathrm{t}, 3 \mathrm{H}$, 
$J=8.0 \mathrm{~Hz}), 7.24(\mathrm{t}, 2 \mathrm{H}, J=8.0 \mathrm{~Hz}) .{ }^{13} \mathrm{C} \mathrm{NMR}\left(\mathrm{CD}_{3} \mathrm{OD}, 500 \mathrm{MHz}\right): \delta 23.1,30.6,35.6$, 44.2, 47.3, 125.8, 128.4, 142.1, 205.0. $\mathrm{MS}(\mathrm{ESI}), \mathrm{m} / \mathrm{z}=257.0[\mathrm{M}+\mathrm{H}]^{+}, 254.8[\mathrm{M}-\mathrm{H}]^{-}$. UPLC1: $t_{\mathrm{R}} 0.36 \mathrm{~min}$, Purity $>99 \%$.

2-oxo-12-phenoxydodecylphosphonic acid (3.6h). Using the above general procedure, Dimethyl 2-oxo-12-phenoxydodecylphosphonate (2.7 mmol), TMSBr $(27.0 \mathrm{mmol})$ and DCM $(2 \mathrm{~mL})$ were used to synthesize 3.6h as a white solid $(66 \%$ overall $), \mathrm{mp}=93-95^{\circ} \mathrm{C}$. ${ }^{1} \mathrm{H}$ NMR $\left(\mathrm{CD}_{3} \mathrm{OD}, 500 \mathrm{MHz}\right): \delta 1.34(\mathrm{bs}, 10 \mathrm{H}), 1.49(\mathrm{~m}, 2 \mathrm{H}), 1.58(\mathrm{~m}, 2 \mathrm{H}), 1.78(\mathrm{~m}$, 2H), $2.67(\mathrm{t}, 2 \mathrm{H}, J=7.0 \mathrm{~Hz}), 3.09(\mathrm{~d}, 2 \mathrm{H}, J=22.5 \mathrm{~Hz}), 3.97(\mathrm{t}, 2 \mathrm{H}, J=6.5 \mathrm{~Hz}), 6.91(\mathrm{~d}$, $2 \mathrm{H}, J=8.0 \mathrm{~Hz}), 6.91(\mathrm{t}, 1 \mathrm{H}, J=7.5 \mathrm{~Hz}), 7.26(\mathrm{t}, 2 \mathrm{H}, J=7.0 \mathrm{~Hz}) .{ }^{13} \mathrm{C} \mathrm{NMR}\left(\mathrm{CD}_{3} \mathrm{OD}\right.$, 500MHz): $\delta$ 23.1, 25.8, 28.7, 29.1, 29.2, 29.3, 43.3, 67.5, 114.1, 120.1, 129.0, 159.2, 204.1. $\mathrm{MS}(\mathrm{ESI}), \mathrm{m} / \mathrm{z}=355.0[\mathrm{M}-\mathrm{H}]^{-}$. UPLC1: $t_{\mathrm{R}} 0.78 \mathrm{~min}$, Purity $>99 \%$.

1,1-difluoro-2-oxoheptadecylphosphonic acid (3.7a). Using the above general procedure, Diethyl 1,1-difluoro-2-oxoheptadecylphosphonic acid (0.1 mmol), TMSBr (1.0 mmol) and DCM (2 mL) were used to synthesize 3.7a as a white solid (52\% overall), $\mathrm{mp}=45-48^{\circ} \mathrm{C} .{ }^{1} \mathrm{H}$ NMR $\left(\mathrm{d}_{6}-\mathrm{DMSO}, 500 \mathrm{MHz}\right): \delta 0.87(\mathrm{t}, 3 \mathrm{H}, J=6.5 \mathrm{~Hz}), 1.25(\mathrm{bs}$, $24 \mathrm{H}), 1.51(\mathrm{~m}, 2 \mathrm{H}), 2.76(\mathrm{t}, 2 \mathrm{H}, J=7.0 \mathrm{~Hz}) .{ }^{13} \mathrm{C}$ NMR $\left(\mathrm{d}_{6}-\mathrm{DMSO}, 500 \mathrm{MHz}\right): \delta 13.2$, 22.3, 28.6, 29.1, 29.2, 29.3, 29.4, 199.8. $\mathrm{MS}(\mathrm{ESI}), \mathrm{m} / \mathrm{z}=371.3[\mathrm{M}+\mathrm{H}]^{+}, 369.1[\mathrm{M}-\mathrm{H}]^{-}$. UPLC1: $t_{\mathrm{R}} 1.19 \mathrm{~min}$, Purity $63 \%$.

1,1-difluoro-2-oxotridecylphosphonic acid (3.7e). Using the above general procedure, Diethyl 1,1-difluoro-2-oxotridecylphosphonic acid (0.1 mmol), TMSBr (1.0 mmol) and $\operatorname{DCM}(2 \mathrm{~mL})$ were used to synthesize 3.7e as a colorless oil $(66 \%$ overall $) .{ }^{1} \mathrm{H} \mathrm{NMR}\left(\mathrm{d}_{6}{ }^{-}\right.$ DMSO, 500MHz): $\delta 0.92(\mathrm{t}, 3 \mathrm{H}, J=7.0 \mathrm{~Hz}), 1.31(\mathrm{bs}, 16 \mathrm{H}), 1.62(\mathrm{~m}, 2 \mathrm{H}), 2.85(\mathrm{t}, 2 \mathrm{H}, J$ $=7.0 \mathrm{~Hz}) .{ }^{13} \mathrm{C}$ NMR $\left(\mathrm{d}_{6}-\mathrm{DMSO}, 500 \mathrm{MHz}\right): \delta \quad 13.1,22.4,28.7,29.1,29.1,29.2,29.3$, 31.7, 37.4, 110.0. $\mathrm{MS}(\mathrm{ESI}), \mathrm{m} / \mathrm{z}=312.9[\mathrm{M}-\mathrm{H}]^{-}$.

(Z)-1,1-difluoro-2-oxononadec-10-enylphosphonic acid (3.7i). Using the above general procedure, Diethyl (Z)-1,1-difluoro-2-oxononadec-10-enylphosphonic acid (0.1 $\mathrm{mmol}), \mathrm{TMSBr}(1.0 \mathrm{mmol})$ and DCM $(2 \mathrm{~mL})$ were used to synthesize 3.7i as a colorless oil $\left(74 \%\right.$ overall). ${ }^{1} \mathrm{H}$ NMR $\left(\mathrm{d}_{6}-\mathrm{DMSO}, 500 \mathrm{MHz}\right): \delta 0.92(\mathrm{t}, 3 \mathrm{H}, J=6.5 \mathrm{~Hz}), 1.34(\mathrm{bd}$, $20 \mathrm{H}), 1.62(\mathrm{~m}, 2 \mathrm{H}), 2.05(\mathrm{q}, 4 \mathrm{H}, J=5.0 \mathrm{~Hz}), 2.86(\mathrm{t}, 2 \mathrm{H}, J=7.0 \mathrm{~Hz}), 5.37(\mathrm{~m}, 2 \mathrm{H}) .{ }^{13} \mathrm{C}$ NMR $\left(\mathrm{d}_{6}\right.$-DMSO, 500MHz): $\delta$ 13.1, 22.4, 24.7, 26.7, 28.7, 28.8, 28.9, 29.0, 29.4, 31.7, 37.4, 129.5, 156.0. MS(ESI), $\mathrm{m} / \mathrm{z}=395.0[\mathrm{M}-\mathrm{H}]^{-}$. UPLC1: $t_{\mathrm{R}} 0.70 \mathrm{~min}$, Purity $96 \%$.

1,1-difluoro-2-oxododec-11-enylphosphonic acid (3.7j). Using the above general procedure, Diethyl 1,1-difluoro-2-oxododec-11-enylphosphonic acid (1.0 mmol), TMSBr $(10.0 \mathrm{mmol})$ and DCM $(2 \mathrm{~mL})$ were used to synthesize $\mathbf{3 . 7} \mathbf{j}$ as a colorless oil $(37 \%$ overall). ${ }^{1} \mathrm{H}$ NMR $\left(\mathrm{CD}_{3} \mathrm{OD}, 500 \mathrm{MHz}\right): \delta 1.27$ (bs, 10H), $1.59(\mathrm{~m}, 2 \mathrm{H}), 2.03(\mathrm{q}, 2 \mathrm{H}, J=$ $5.0 \mathrm{~Hz}), 2.78(\mathrm{t}, 2 \mathrm{H}, J=7.0 \mathrm{~Hz}), 4.96(\mathrm{dd}, 2 \mathrm{H}, J=25 \mathrm{~Hz}, 15 \mathrm{~Hz}), 5.80(\mathrm{~m}, 1 \mathrm{H}) .{ }^{13} \mathrm{C}$ NMR (CD $\left.{ }_{3} \mathrm{OD}, 500 \mathrm{MHz}\right): \delta$ 22.4, 28.6, 28.7, 28.8, 29.0, 29.1, 33.5, 37.4, 113.3, 138.7. $\mathrm{MS}(\mathrm{ESI}), \mathrm{m} / \mathrm{z}=296.9[\mathrm{M}-\mathrm{H}]^{-}$. UPLC1: $t_{\mathrm{R}} 0.51 \mathrm{~min}$, Purity $80 \%$.

1-oxohexadecylphosphoramidic acid (3.11a). Using the above general procedure, (Diethyl) 1-oxohexadecylphosphoramidate $(1.0 \mathrm{mmol}), \mathrm{TMSBr}(1.0 \mathrm{mmol})$ and DCM (2 
$\mathrm{mL}$ ) were used to synthesize 3.11a as a white solid (24\% overall), $\mathrm{mp}=56-58^{\circ} \mathrm{C} .{ }^{1} \mathrm{H}$ NMR (d $\left.{ }_{6}-\mathrm{DMSO}, 500 \mathrm{MHz}\right): \delta 0.87(\mathrm{t}, 3 \mathrm{H}, J=6.5 \mathrm{~Hz}), 1.25(\mathrm{bs}, 24 \mathrm{H}), 1.47(\mathrm{~m}, 2 \mathrm{H})$, $2.18(\mathrm{t}, 2 \mathrm{H}, J=7.0 \mathrm{~Hz}), 8.98(\mathrm{~d}, 1 \mathrm{H}, J=9.0 \mathrm{~Hz}) .{ }^{13} \mathrm{C}$ NMR $\left(\mathrm{d}_{6}-\mathrm{DMSO}, 500 \mathrm{MHz}\right): \delta$ 13.0, 22.3, 26.6, 28.9, 29.0, 29.3, 29.3, 29.4, 31.7, 35.6, 36.6, 39.4, 110.0, 166.7. $\mathrm{MS}(\mathrm{ESI}), \mathrm{m} / \mathrm{z}=334.3[\mathrm{M}-\mathrm{H}]^{-}$.

(Z)-1-oxooctadec-11-enylphosphoramidic acid (3.11b). Using the above general procedure, (Diethyl) (Z)-1-oxooctadec-11-enylphosphoramidate (0.1 mmol), TMSBr (1.0 $\mathrm{mmol})$ and DCM $(2 \mathrm{~mL})$ were used to synthesize 3.11b as a white solid (19\% overall), $\mathrm{mp}=76-80^{\circ} \mathrm{C} .{ }^{1} \mathrm{H}$ NMR $\left(\mathrm{d}_{6}-\mathrm{DMSO}, 500 \mathrm{MHz}\right): \delta 0.93(\mathrm{t}, 3 \mathrm{H}, J=7.0 \mathrm{~Hz}), 1.33(\mathrm{bs}$, $20 \mathrm{H}), 1.64(\mathrm{~m}, 2 \mathrm{H}), 2.05(\mathrm{q}, 4 \mathrm{H}, J=9.0 \mathrm{~Hz}), 2.32(\mathrm{t}, 2 \mathrm{H}, J=7.0 \mathrm{~Hz}), 5.37(\mathrm{~m}, 2 \mathrm{H}) .{ }^{13} \mathrm{C}$ NMR $\left(\mathrm{d}_{6}\right.$-DMSO, 500MHz): $\delta$ 13.1, 22.3, 24.9, 26.8, 28.6, 28.9, 29.0, 29.1, 29.2, 29.5, $31.5,129.5,176.5$. MS (ESI), $\mathrm{m} / \mathrm{z}=360.1[\mathrm{M}-\mathrm{H}]^{-}$.

1-oxooctylphosphoramidic acid (3.11c). Using the above general procedure, (Diethyl) 1-oxooctylphosphoramidate $(1.5 \mathrm{mmol}), \mathrm{TMSBr}(15.0 \mathrm{mmol})$ and DCM $(2 \mathrm{~mL})$ were used to synthesize 3.11c as a white solid $(32 \%$ overall $), \mathrm{mp}=75-77^{\circ} \mathrm{C}$. ${ }^{1} \mathrm{H} \mathrm{NMR}$ $\left(\mathrm{CD}_{3} \mathrm{OD}, 500 \mathrm{MHz}\right): \delta 0.93(\mathrm{t}, 3 \mathrm{H}, J=7.0 \mathrm{~Hz}), 1.35(\mathrm{bs}, 8 \mathrm{H}), 1.64(\mathrm{~m}, 2 \mathrm{H}), 2.32(\mathrm{bs}$, $2 \mathrm{H}) ;{ }^{13} \mathrm{C} \mathrm{NMR}\left(\mathrm{CD}_{3} \mathrm{OD}, 500 \mathrm{MHz}\right): \delta$ 13.1, 22.3, 24.8, 28.8, 31.5, 176.8. MS(ESI), m/z $=221.9[\mathrm{M}-\mathrm{H}]^{-}, 224.0[\mathrm{M}+\mathrm{H}]^{+}$.

1-oxododecylphosphoramidic acid (3.11d). Using the above general procedure, (Diethyl) 1-oxododecylphosphoramidate (0.6 mmol), TMSBr (6.0 mmol) and DCM (2 $\mathrm{mL})$ were used to synthesize $\mathbf{3 . 1 1 d}$ as a white solid (10\% overall). ${ }^{1} \mathrm{H}$ NMR $\left(\mathrm{CD}_{3} \mathrm{OD}\right.$, $500 \mathrm{MHz}): \delta 0.92(\mathrm{t}, 3 \mathrm{H}, J=6.5 \mathrm{~Hz}), 1.32(\mathrm{bs}, 16 \mathrm{H}), 1.63(\mathrm{~m}, 2 \mathrm{H}), 2.31(\mathrm{t}, 2 \mathrm{H}, J=$ 7.5Hz). ${ }^{13} \mathrm{C}$ NMR $\left(\mathrm{CD}_{3} \mathrm{OD}, 500 \mathrm{MHz}\right): \delta \quad 13.0,22.3,24.8,28.8,29.0,29.2,29.3,31.7$, 168.6. $\mathrm{MS}(\mathrm{ESI}), \mathrm{m} / \mathrm{z}=277.9[\mathrm{M}-\mathrm{H}]^{-}, 280.1[\mathrm{M}+\mathrm{Na}]^{+}$.

5-cyclohexyl-1-oxopentylphosphoramidic acid (3.11e). Using the above general procedure, (Diethyl) 5-cyclohexyl-1-oxopentylphosphoramidate (0.6 mmol), TMSBr (6.0 mmol) and DCM (2 mL) were used to synthesize 3.11e as a white solid (35\% overall). ${ }^{1} \mathrm{H}$ NMR $\left(\mathrm{CD}_{3} \mathrm{OD}, 500 \mathrm{MHz}\right): \delta 0.90(\mathrm{~m}, 2 \mathrm{H}), 1.23(\mathrm{~m}, 6 \mathrm{H}), 1.37(\mathrm{~m}, 2 \mathrm{H}), 1.61(\mathrm{~m}, 2 \mathrm{H})$, $1.73(\mathrm{~m}, 2 \mathrm{H}), 2.32(\mathrm{t}, 2 \mathrm{H}, J=7.5 \mathrm{~Hz}) .{ }^{13} \mathrm{C} \mathrm{NMR}\left(\mathrm{CD}_{3} \mathrm{OD}, 500 \mathrm{MHz}\right): \delta 25.1,26.1,26.4$, 33.2, 37.0, 37.5, 176.7. $\mathrm{MS}(\mathrm{ESI}), \mathrm{m} / \mathrm{z}=264.1[\mathrm{M}+\mathrm{H}]^{+}, 261.9[\mathrm{M}-\mathrm{H}]^{-}$.

1-oxo-11-phenoxyundecylphosphoramidic acid (3.11f). Using the above general procedure, (Diethyl) 1-oxo-11-phenoxyundecylphosphoramidate (0.5 mmol), TMSBr $(5.0 \mathrm{mmol})$ and DCM $(2 \mathrm{~mL})$ were used to synthesize $\mathbf{3 . 1 1 f}$ as a white solid $(15 \%$ overall), $\mathrm{mp}=100-103^{\circ} \mathrm{C} .{ }^{1} \mathrm{H}$ NMR $\left(\mathrm{CD}_{3} \mathrm{OD}, 500 \mathrm{MHz}\right): \delta 1.35(\mathrm{bs}, 10 \mathrm{H}), 1.49(\mathrm{~m}, 2 \mathrm{H})$, $1.63(\mathrm{~m}, 2 \mathrm{H}), 1.77(\mathrm{~m}, 2 \mathrm{H}), 2.32(\mathrm{bt}, 2 \mathrm{H}, J=7.5 \mathrm{~Hz}), 3.96(\mathrm{t}, 2 \mathrm{H}, J=7.0 \mathrm{~Hz}), 6.91(\mathrm{t}$, $3 \mathrm{H}, 8.0 \mathrm{~Hz}), 7.26(\mathrm{t}, 2 \mathrm{H}, J=7.5 \mathrm{~Hz}) .{ }^{13} \mathrm{C} \mathrm{NMR}\left(\mathrm{CD}_{3} \mathrm{OD}, 500 \mathrm{MHz}\right): \delta 24.8,25.8,28.8$, 29.0, 29.1, 29.3, 67.5, 114.1, 120.1, 129.0, 159.2, 176.6. $\mathrm{MS}(\mathrm{ESI}), \mathrm{m} / \mathrm{z}=358.3[\mathrm{M}+\mathrm{H}]^{+}$, $356.0[\mathrm{M}-\mathrm{H}]^{-}$.

(Tetradecylcarbamoyl)methylphosphonic acid (3.14a). Using the above general procedure, Diethyl (Tetradecylcarbamoyl)methylphosphonic acid (1.0 mmol), TMSBr 
(30.0 mmol) and DCM (2 mL) were used to synthesize 3.14a as a white solid $(10 \%$ overall), $\mathrm{mp}=133-135^{\circ} \mathrm{C} .{ }^{1} \mathrm{H}$ NMR $\left(\mathrm{d}_{6}-\mathrm{DMSO}, 500 \mathrm{MHz}\right): \delta 0.87(\mathrm{t}, 3 \mathrm{H}, J=6.5 \mathrm{~Hz})$, 1.25 (bs, 22H), $1.38(\mathrm{~m}, 2 \mathrm{H}), 2.57(\mathrm{~d}, 2 \mathrm{H}, J=20.5 \mathrm{~Hz}), 3.03(\mathrm{q}, 2 \mathrm{H}, J=6.0 \mathrm{~Hz}), 7.74(\mathrm{t}$, $1 \mathrm{H}, J=5.5 \mathrm{~Hz}) .{ }^{13} \mathrm{C}$ NMR $\left(\mathrm{d}_{6}-\mathrm{DMSO}, 500 \mathrm{MHz}\right): \delta \quad 13.0,22.3,26.6,28.8,29.0,29.2$, 29.4, 31.7, 39.4, MS(ESI), $\mathrm{m} / \mathrm{z}=334.1[\mathrm{M}-\mathrm{H}]^{-}, \mathrm{m} / \mathrm{z}=336.3[\mathrm{M}+\mathrm{H}]^{+}$. UPLC1: $t_{\mathrm{R}} 1.75$ min, Purity $>99 \%$.

((Z)-octadec-9-enylcarbamoyl)methylphosphonic acid (3.14b). Using the above general procedure, Diethyl ((Z)-octadec-9-enylcarbamoyl)methylphosphonic acid (0.1 $\mathrm{mmol}), \mathrm{TMSBr}(3.0 \mathrm{mmol})$ and DCM $(2 \mathrm{~mL})$ were used to synthesize $\mathbf{3 . 1 4 b}$ as a white solid $(17 \%$ overall $), \mathrm{mp}=111-114^{\circ} \mathrm{C} .{ }^{1} \mathrm{H} \mathrm{NMR}\left(\mathrm{CD}_{3} \mathrm{OD}, 500 \mathrm{MHz}\right): \delta 0.92(\mathrm{t}, 3 \mathrm{H}, J=$ $6.5 \mathrm{~Hz}), 1.33(\mathrm{bd}, 22 \mathrm{H}), 1.54(\mathrm{~m}, 2 \mathrm{H}), 2.05(\mathrm{~m}, 4 \mathrm{H}), 2.81(\mathrm{~d}, 2 \mathrm{H}, J=21.0 \mathrm{~Hz}), 3.21(\mathrm{t}$, $2 \mathrm{H}, J=7.5 \mathrm{~Hz}), 5.37(\mathrm{~m}, 2 \mathrm{H}) .{ }^{13} \mathrm{C} \mathrm{NMR}\left(\mathrm{CD}_{3} \mathrm{OD}, 500 \mathrm{MHz}\right): \delta 13.01,22.4,26.6,26.8$, $28.9,29.0,29.1,29.2,29.4,29.5,31.7,38.9,39.5,129.5,166.7 . \quad \mathrm{MS}(\mathrm{ESI}), \mathrm{m} / \mathrm{z}=388.0$ $[\mathrm{M}-\mathrm{H}]^{-}$. UPLC1: $t_{\mathrm{R}} 1.32 \mathrm{~min}$, Purity $96 \%$.

(N-dodecyl-N-methylcarbamoyl)methylphosphonic acid (3.14c). Using the above general procedure, Diethyl (N-dodecyl-N-methylcarbamoyl)methylphosphonic acid (0.1 mmol), TMSBr $(3.0 \mathrm{mmol})$ and DCM $(2 \mathrm{~mL})$ were used to synthesize $\mathbf{3 . 1 4 c}$ as a white solid $(10 \%$ overall $), \mathrm{mp}=80-83^{\circ} \mathrm{C} .{ }^{1} \mathrm{H} \mathrm{NMR}\left(\mathrm{CD}_{3} \mathrm{OD}, 500 \mathrm{MHz}\right): \delta 0.92(\mathrm{t}, 3 \mathrm{H}, J=6.5$ $\mathrm{Hz}), 1.31(\mathrm{bs}, 18 \mathrm{H}), 1.62(\mathrm{~m}, 2 \mathrm{H}), 3.06(\mathrm{~d}, 2 \mathrm{H}, J=22.5 \mathrm{~Hz}), 3.06(\mathrm{bd}, 3 \mathrm{H}), 3.44(\mathrm{dt}, 2 \mathrm{H}$, $J=7.5 \mathrm{~Hz}, 29.5 \mathrm{~Hz}) .{ }^{13} \mathrm{C} \mathrm{NMR}\left(\mathrm{CD}_{3} \mathrm{OD}, 500 \mathrm{MHz}\right): \delta 13.1,22.3,26.5,26.7,27.9,29.1$, 29.4, 31.7, 33.0, 36.0, 51.1, 167.4. $\mathrm{MS}(\mathrm{ESI}), \mathrm{m} / \mathrm{z}=320.0[\mathrm{M}-\mathrm{H}]^{-}, \mathrm{m} / \mathrm{z}=322.3[\mathrm{M}+\mathrm{H}]^{+}$. UPLC1: $t_{\mathrm{R}} 0.83 \mathrm{~min}$, Purity $>99 \%$.

(Heptylcarbamoyl)methylphosphonic acid (3.14d). Using the above general procedure, Diethyl (Heptylcarbamoyl)methylphosphonic acid (0.1 mmol), TMSBr (3.0 $\mathrm{mmol})$ and DCM (2 mL) were used to synthesize 3.14d as a white solid (28\% overall), $\mathrm{mp}=137-140^{\circ} \mathrm{C} .{ }^{1} \mathrm{H}$ NMR $\left(\mathrm{CD}_{3} \mathrm{OD}, 500 \mathrm{MHz}\right): \delta 0.93(\mathrm{t}, 3 \mathrm{H}, J=6.0 \mathrm{~Hz}), 1.34(\mathrm{bm}$, $8 \mathrm{H}) 1.54(\mathrm{~m}, 2 \mathrm{H}), 2.81(\mathrm{~d}, 2 \mathrm{H}, J=21.0 \mathrm{~Hz}), 3.21(\mathrm{t}, 2 \mathrm{H}, J=7.0 \mathrm{~Hz}) .{ }^{13} \mathrm{C} N M R\left(\mathrm{CD}_{3} \mathrm{OD}\right.$, $500 \mathrm{MHz}): \delta 13.0,22.3,26.5,28.7,28.9,31.5,35.6,39.4,166.7 . \quad \mathrm{MS}(\mathrm{ESI}), \mathrm{m} / \mathrm{z}=$ $235.8[\mathrm{M}-\mathrm{H}]^{-}, \mathrm{m} / \mathrm{z}=238.0[\mathrm{M}+\mathrm{H}]^{+}$. UPLC1: $t_{\mathrm{R}} 0.35 \mathrm{~min}$, Purity $>99 \%$.

General procedure for synthesis of acylsulfamates (3.19a-d). Anhydrous formic acid $\left(99 \%, 2.0\right.$ eq) was added drop-wise to chlorosulfonyl isocyanate $(2.0 \mathrm{eq})$ at $0^{\circ} \mathrm{C}$ under argon. The mixture was allowed to rise to room temperature and stirred until gas evolution stopped $(\sim 2 \mathrm{~h})$. The desired alcohol $(1.0 \mathrm{eq})$ in DMA $(30 \mathrm{~mL})$ was added dropwise to the resulting sulfamoyl chloride at $0^{\circ} \mathrm{C}$ under argon. The mixture was allowed to stir at $0^{\circ} \mathrm{C}$ for $10 \mathrm{~min}$, then allowed to warm to room temperature and stirred an additional $3 \mathrm{~h}$. The mixture was then poured into cold brine $(100 \mathrm{~mL})$ and extracted with ethyl acetate. The combined extracts were washed with water and brine, then dried over $\mathrm{Na}_{2} \mathrm{SO}_{4}$ and concentrated in vacuo. The residue was purified via flash chromatography in Hexane/ EtOAc to afford the desired sulfamate ester (3.17). Acid chlorides were generated by adding oxalyl chloride (2.0 eq) and DMF (2 drops) to appropriate acids (1.0 eq) in THF $(15 \mathrm{~mL})$ at $0^{\circ} \mathrm{C}$ under argon. After gas evolution stopped ( $\left.20 \mathrm{~min}\right)$ the mixture was warmed to room temperature and allowed to stir for $2 \mathrm{~h}$. The resulting 
mixture was concentrated in vacuo then dissolved in DCM/DMF (1:1, $5 \mathrm{~mL})$ and added drop-wise to a mixture of previously prepared sulfamate ester, 3.17 (1.0 eq), DMAP (cat., $10 \% \mathrm{~mol})$, triethylamine $(3.0 \mathrm{eq})$ in DCM/DMF $(1: 1,15 \mathrm{~mL})$. The mixture was allowed to stir for $16 \mathrm{~h}$ under argon. The mixture was diluted with DCM and washed with $1 \mathrm{~N}$ $\mathrm{HCl}$, water, and brine then dried over $\mathrm{Na}_{2} \mathrm{SO}_{4}$ and concentrated in vacuo. The residue was purified via flash chromatography $(0-100 \%$, Hexane/Ethyl Acetate) to afford the desired acylsulfamate.

Ethyl palmitoylsulfamate (3.19a). Using the above general procedure, chlorosulfonyl isocyanate $(40.0 \mathrm{mmol})$, formic acid $(40.0 \mathrm{mmol})$, ethanol $(20.0 \mathrm{mmol})$, DMA $(30 \mathrm{~mL})$, palmitic acid $(6.0 \mathrm{mmol})$, oxalylchloride $(12.0 \mathrm{mmol})$, triethylamine $(18.0 \mathrm{mmol})$, and DMAP $(0.6 \mathrm{mmol})$ were used to synthesize 3.19a as a white solid $(25 \%), \mathrm{mp}=85-87^{\circ} \mathrm{C}$. TLC $R_{f}=0.5\left(8: 2, \mathrm{CHCl}_{3}: \mathrm{MeOH}\right) .{ }^{1} \mathrm{H} \mathrm{NMR}\left(\mathrm{CDCl}_{3}, 500 \mathrm{MHz}\right): \delta 0.88(\mathrm{t}, 3 \mathrm{H}, J=6.0$ $\mathrm{Hz}), 1.26(\mathrm{bs}, 24 \mathrm{H}), 1.43(\mathrm{t}, 3 \mathrm{H}, J=7.0 \mathrm{~Hz}), 1.66(\mathrm{~m}, 2 \mathrm{H}), 2.39(\mathrm{t}, 2 \mathrm{H}, J=7.5 \mathrm{~Hz}), 4.48$ $(\mathrm{q}, 2 \mathrm{H}, J=8.0 \mathrm{~Hz}), 8.39(\mathrm{~s}, 1 \mathrm{H}) .{ }^{13} \mathrm{C} \mathrm{NMR}\left(\mathrm{CDCl}_{3}, 500 \mathrm{MHz}\right): \delta 14.1,14.7,22.7,24.4$, 29.0, 29.3, 29.4, 29.6, 29.7, 31.9, 35.9, 70.8, 171.3. $\mathrm{MS}(\mathrm{ESI}), \mathrm{m} / \mathrm{z}=386.3[\mathrm{M}+\mathrm{Na}]^{+}$, $362.1[\mathrm{M}-\mathrm{H}]^{-}$. UPLC1: $t_{\mathrm{R}} 1.57$ min, Purity $>99 \%$.

Butyl palmitoylsulfamate (3.19b). Using the above general procedure, Chlorosulfonyl isocyanate $(40.0 \mathrm{mmol})$, formic acid $(40.0 \mathrm{mmol})$, butanol $(20.0 \mathrm{mmol})$, DMA $(30 \mathrm{~mL})$, palmitic acid $(6.0 \mathrm{mmol})$, oxalylchloride $(12.0 \mathrm{mmol})$, triethylamine $(18.0 \mathrm{mmol})$, and DMAP $(0.6 \mathrm{mmol})$ were used to synthesize $3.19 \mathrm{~b}$ as a white solid $(46 \%), \mathrm{mp}=74-76^{\circ} \mathrm{C}$. TLC $R_{f}=0.5\left(8: 2, \mathrm{CHCl}_{3}: \mathrm{MeOH}\right) .{ }^{1} \mathrm{H} \mathrm{NMR}\left(\mathrm{CDCl}_{3}, 500 \mathrm{MHz}\right): \delta 0.88(\mathrm{t}, 3 \mathrm{H}, J=6.5$ $\mathrm{Hz}), 0.95$ (t, 3H, $J=7.5 \mathrm{~Hz}), 1.26$ (bs, 24H), $1.44(\mathrm{~m}, 2 \mathrm{H}), 1.65(\mathrm{~m}, 2 \mathrm{H}), 1.75(\mathrm{~m}, 2 \mathrm{H})$, $2.39(\mathrm{t}, 2 \mathrm{H}, J=7.5 \mathrm{~Hz}), 4.40(\mathrm{t}, 2 \mathrm{H}, J=6.5 \mathrm{~Hz}), 8.18(\mathrm{~s}, 1 \mathrm{H}) .{ }^{13} \mathrm{C} \mathrm{NMR}\left(\mathrm{CDCl}_{3}\right.$, 500MHz): $\delta$ 13.4, 14.1, 18.6, 22.7, 24.4, 29.0, 29.3, 29.4, 29.6, 29.7, 30.8, 31.9, 35.9, 74.4, 171.4. $\mathrm{MS}(\mathrm{ESI}), \mathrm{m} / \mathrm{z}=414.4[\mathrm{M}+\mathrm{Na}]^{+}, 390.1[\mathrm{M}-\mathrm{H}]^{-}$. UPLC1: $t_{\mathrm{R}} 1.74 \mathrm{~min}$, Purity $>99 \%$.

4-methoxyphenyl palmitoylsulfamate (3.19c). Using the above general procedure, Chlorosulfonyl isocyanate $(40.0 \mathrm{mmol})$, formic acid (40.0 mmol), 4-methoxyphenol (20.0 mmol), DMA $(30 \mathrm{~mL})$, palmitic acid $(6.0 \mathrm{mmol})$, oxalylchloride $(12.0 \mathrm{mmol})$, triethylamine $(18.0 \mathrm{mmol})$, and DMAP $(0.6 \mathrm{mmol})$ were used to synthesize $3.19 \mathrm{c}$ as a white solid $(10 \%), \mathrm{mp}=74-76^{\circ} \mathrm{C}$. TLC $R_{f}=0.9$ (Ethyl Acetate). ${ }^{1} \mathrm{H}$ NMR $\left(\mathrm{CDCl}_{3}\right.$, $300 \mathrm{MHz}): \delta 0.90(\mathrm{t}, 3 \mathrm{H}, J=6.5 \mathrm{~Hz}), 1.27(\mathrm{bs}, 24 \mathrm{H}), 1.64(\mathrm{~m}, 2 \mathrm{H}), 2.38(\mathrm{t}, 2 \mathrm{H}, J=7.0$ $\mathrm{Hz}), 3.81(\mathrm{~s}, 3 \mathrm{H}), 6.89(\mathrm{~d}, 2 \mathrm{H}, J=9.0 \mathrm{~Hz}), 7.21,(\mathrm{~d}, 2 \mathrm{H}, J=9.0 \mathrm{~Hz}) .{ }^{13} \mathrm{C} \mathrm{NMR}\left(\mathrm{CDCl}_{3}\right.$, $500 \mathrm{MHz}): \delta 14.1,22.7,24.5,29.0,29.3,29.4,29.5,29.6,29.7,31.9,36.2,55.6,114.18$, 122.3, 143.2, 158.7, 171.4. MS(ESI), $\mathrm{m} / \mathrm{z}=464.2[\mathrm{M}+\mathrm{Na}]^{+}, 440.0[\mathrm{M}-\mathrm{H}]^{-}$. UPLC1: $t_{\mathrm{R}}$ 1.58 min, Purity $>99 \%$.

4-methoxyphenyl 5-phenylpentanoylsulfamate (3.19d). Using the above general procedure, Chlorosulfonyl isocyanate $(40.0 \mathrm{mmol})$, formic acid $(40.0 \mathrm{mmol}), 4-$ methoxyphenol (20.0 mmol), DMA (30 mL), 5-phenylpentanoic acid (6.0 mmol), oxalylchloride $(12.0 \mathrm{mmol})$, triethylamine $(18.0 \mathrm{mmol})$, and DMAP $(0.6 \mathrm{mmol})$ were used to synthesize 3.19d as a colorless waxy solid (10\%). TLC $R_{f}=0.8$ (Ethyl Acetate). ${ }^{1} \mathrm{H} \mathrm{NMR}\left(\mathrm{CDCl}_{3}, 300 \mathrm{MHz}\right): \delta 1.60(\mathrm{bs}, 4 \mathrm{H}), 2.32(\mathrm{t}, 2 \mathrm{H}, J=6.0 \mathrm{~Hz}), 2.57(\mathrm{t}, 2 \mathrm{H}, J=7.0$ 
$\mathrm{Hz}), 3.73(\mathrm{~s}, 3 \mathrm{H}), 6.81(\mathrm{~d}, 2 \mathrm{H}, J=9.0 \mathrm{~Hz}), 7.22(\mathrm{~m}, 7 \mathrm{H}) .{ }^{13} \mathrm{C} \mathrm{NMR}\left(\mathrm{CDCl}_{3}, 500 \mathrm{MHz}\right)$ : $\delta$ 24.2, 30.7, 35.5, 36.5, 55.6, 114.8, 122.9, 125.9, 128.4, 141.9, 143.4, 158.6, 171.3. $\mathrm{MS}(\mathrm{ESI}), \mathrm{m} / \mathrm{z}=386.1[\mathrm{M}+\mathrm{Na}]^{+}, 361.9[\mathrm{M}-\mathrm{H}]^{-}$. UPLC1: $t_{\mathrm{R}} 0.61 \mathrm{~min}$, Purity $>99 \%$.

Synthesis of acylsulfamide (3.20a,b). Anhydrous formic acid (99\%, 2.0 eq) was added drop-wise to chlorosulfonyl isocyanate $(2.0 \mathrm{eq})$ at $0^{\circ} \mathrm{C}$ under argon. The mixture was allowed to rise to room temperature and stirred until gas evolution stopped $(\sim 2 \mathrm{~h})$. Propylamine $(1.0 \mathrm{eq})$ was added drop-wise to the resulting sulfamoyl chloride at $0^{\circ} \mathrm{C}$ under argon. The mixture was allowed to stir at $0^{\circ} \mathrm{C}$ for $30 \mathrm{~min}$, and then warmed to room temperature. $\mathrm{NaOH}(5 \mathrm{~mL})$ was added to the mixture and stirred for $1 \mathrm{~h}$. The mixture was then extracted with Ethyl Acetate. The combined extracts were washed with brine, then dried over $\mathrm{Na}_{2} \mathrm{SO}_{4}$ and concentrated in vacuo to afford the propylsulfamide ester $(3.18$ a,b). The acid chloride was generated by adding oxalyl chloride $(2.0 \mathrm{eq})$ and $\operatorname{DMF}(10 \% \mathrm{~mol})$ to the appropriate acid $(1.0 \mathrm{eq})$ in $\mathrm{THF}(15 \mathrm{~mL})$ at $0^{\circ} \mathrm{C}$ under argon. After gas evolution stopped ( $\sim 20 \mathrm{~min})$ the mixture was warmed to room temperature and allowed to stir for $2 \mathrm{~h}$. The resulting mixture was concentrated in vacuo then dissolved in DCM/DMF (1:1, $5 \mathrm{~mL})$ and added drop-wise to a mixture of previously prepared propylsulfamide ester, 3.18a,b (1.0 eq), DMAP (10\% mol), triethylamine (3.0 eq) in DCM/DMF (1:1, $15 \mathrm{~mL})$. The mixture was allowed to stir for $16 \mathrm{~h}$ under argon. The mixture was diluted with DCM and washed with $1 \mathrm{~N} \mathrm{HCl,} \mathrm{water,} \mathrm{and} \mathrm{brine} \mathrm{then} \mathrm{dried}$ over $\mathrm{Na}_{2} \mathrm{SO}_{4}$ and concentrated in vacuo. The residue was purified via flash chromatography (0-100\%, Hexane/Ethyl Acetate) to afford the desired acylsulfamide.

Palmitoyl N-propylsulfamide (3.20a). Using the above general procedure, chlorosulfonyl isocyanate $(40.0 \mathrm{mmol})$, formic acid $(40.0 \mathrm{mmol})$, propanol $(20.0 \mathrm{mmol})$, palmitic acid $(6.0 \mathrm{mmol})$, oxalylchloride $(12.0 \mathrm{mmol})$, triethylamine $(18.0 \mathrm{mmol})$, and DMAP $(0.6 \mathrm{mmol})$ were used to synthesize 3.20a as a white solid $(15 \%)$, ${ }^{1} \mathrm{H}$ NMR $\left(\mathrm{CDCl}_{3}, 500 \mathrm{MHz}\right): \delta 0.88(\mathrm{t}, 3 \mathrm{H}, J=7.0 \mathrm{~Hz}), 0.92(\mathrm{t}, 3 \mathrm{H}, J=7.5 \mathrm{~Hz}), 1.25(\mathrm{bs}, 24 \mathrm{H})$, $1.51(\mathrm{~m}, 2 \mathrm{H}), 1.62(\mathrm{~m} 2 \mathrm{H}), 2.15(\mathrm{t}, 2 \mathrm{H}, J=8.0 \mathrm{~Hz}), 3.21(\mathrm{q}, 2 \mathrm{H}, J=9.0 \mathrm{~Hz}), 5.43(\mathrm{bs}$, 1H). ${ }^{13} \mathrm{C} \mathrm{NMR}\left(\mathrm{CDCl}_{3}, 500 \mathrm{MHz}\right): \delta 11.4,14.1,22.7,22.9,25.9,29.3,29.4,29.5,29.6$, 29.7, 31.9, 36.9, 41.2, 173.2. $\mathrm{MS}(\mathrm{ESI}), \mathrm{m} / \mathrm{z}=375.1[\mathrm{M}-\mathrm{H}]^{-}$.

Oleoyl N-propylsulfamide (3.20b). Using the above general procedure, chlorosulfonyl isocyanate $(40.0 \mathrm{mmol})$, formic acid $(40.0 \mathrm{mmol})$, propanol $(20.0 \mathrm{mmol})$, oleic acid (6.0 mmol), oxalylchloride $(12.0 \mathrm{mmol})$, triethylamine $(18.0 \mathrm{mmol})$, and DMAP (0.6 mmol) were used to synthesize 3.20b as a waxy solid $(8 \%) . R_{f}=0.7\left(8: 2, \mathrm{CHCl}_{3}: \mathrm{MeOH}\right){ }^{1} \mathrm{H}$ $\operatorname{NMR}\left(\mathrm{CDCl}_{3}, 500 \mathrm{MHz}\right): \delta 0.88(\mathrm{t}, 3 \mathrm{H}, J=6.5 \mathrm{~Hz}), 0.94(\mathrm{t}, 3 \mathrm{H}, J=7.0 \mathrm{~Hz}), 1.28(\mathrm{bs}$, $20 \mathrm{H}), 1.59(\mathrm{~m}, 4 \mathrm{H}), 2.00(\mathrm{~m}, 4 \mathrm{H}), 2.62(\mathrm{t}, 2 \mathrm{H}, J=7.5 \mathrm{~Hz}), 2.95(\mathrm{t}, 2 \mathrm{H}, J=6.5 \mathrm{~Hz}), 5.34$ $(\mathrm{m}, 2 \mathrm{H}) .{ }^{13} \mathrm{C} \mathrm{NMR}\left(\mathrm{CDCl}_{3}, 500 \mathrm{MHz}\right): \delta 11.3,14.1,22.5 .22 .7,27.2,29.2,29.3,29.5$, 29.7, 29.8, 31.9, 45.6, 129.6, 130.1, 174.8. MS(ESI), $\mathrm{m} / \mathrm{z}=401.1[\mathrm{M}-\mathrm{H}]^{-}$. UPLC1: $t_{\mathrm{R}}$ 2.01 min, Purity $>99 \%$. 
Preparation and Assay of Acyltransferase Activity

E. coli membranes were purified and acyltransferase activity was measured as described previously. ${ }^{153}$ Briefly, the reaction buffer contained $100 \mathrm{mM}$ Tris-HCL, $\mathrm{pH} 7.4$, $150 \mathrm{~mm} \mathrm{NaCl}, 1 \mathrm{mg} / \mathrm{ml} \mathrm{BSA}, 5 \mathrm{mM} \mathrm{Na}_{3} \mathrm{VO}_{4}, 200 \mu \mathrm{M}$ inhibitor and purified membranes. $16: 0 \mathrm{PO}_{4}$ was added to $50 \mu \mathrm{M}$ start the reaction. Reactions were terminated after incubation at $37^{\circ} \mathrm{C}$ for $20 \mathrm{~min}$ by pipetting $20 \mu \mathrm{l}$ of the reaction mixture onto a Whatman $3 \mathrm{MM}$ cellulose filter disc. Filter discs were washed in $10 \%, 5 \%$, and $1 \%$ ice-cold trichloroacetic acid (20min, $20 \mathrm{ml} /$ disk) prior to scintillation counting. The $\mathrm{K}_{\mathrm{M}}$ for 16:0$\mathrm{PO}_{4}$ was obtained by varying the concentration of $16: 0-\mathrm{PO}_{4}$ from 3.125 to $50 \mu \mathrm{M}$ at a fixed $\left[{ }^{14} \mathrm{C}\right] \mathrm{G} 3 \mathrm{P}$ concentratin of $200 \mu \mathrm{M}$.

\section{MIC Determinations}

The MIC of each test compound was determined by the microbroth dilution method in Mueller-Hinton (MH) media according to the Clinical Laboratory Standards Institute (CLSI) document M7-A7 for testing of the antibiotic susceptibility of aerobic bacteria. For growth of $S$. pneumoniae and $S$. pyogenes, MH broth was supplemented with 5\% lysed horse blood from BD Diagnostic Systems. All test compounds were dissolved in DMSO at a concentration of $10 \mathrm{mg} / \mathrm{ml}$ and stored at $-80^{\circ} \mathrm{C}$. Two fold serial dilutions of test compound were prepared in $\mathrm{MH}$ broth in 96-well plates to give drug concentrations ranging from 400 to $0.025 \mu \mathrm{g} / \mathrm{ml}$. Bacterial inoculum was prepared by streaking a $-80^{\circ} \mathrm{C}$ stock bacterial culture onto an $\mathrm{MH}$ agar plate, which was incubated overnight at $37^{\circ} \mathrm{C} .2-3$ colonies were picked from the plate and used to establish a bacterial inoculum at an optical density of $\lambda_{600}=0.1$ in $\mathrm{MH}$ broth, which was further diluted to an $\mathrm{OD} \lambda_{600}=0.001 .100 \mu 1$ of culture was then added to each well of the 96-well plate resulting in an $\mathrm{OD} \lambda_{600}=0.0005$, which corresponds to about $10^{5} \mathrm{CFU} / \mathrm{ml}$, and final antibiotic concentrations ranging from 200 to $0.0125 \mu \mathrm{g} / \mathrm{ml}$. The $96-w e l l$ plates were incubated overnight at $37^{\circ} \mathrm{C}$ and the MIC was recorded as the lowest concentration of drug that inhibited visible bacterial growth.

Cytotoxicity Assay

Vero monkey epithelial cells (ATCC CCL-81) were cultured in Dulbecco's Modified Eagle's Medium supplemented with 10\% fetal bovine serum and maintained in a humidified incubator $\left(37^{\circ} \mathrm{C}, 5 \% \mathrm{CO}_{2}\right)$. Cells were dislodged with a cell scraper, collected by centrifugation, resuspended in fresh medium at $\sim 106$ cells $/ \mathrm{mL}$, dispensed into 96 -well microtiter plates $(100 \mu \mathrm{l} /$ well $)$ and incubated for $18 \mathrm{~h}$ at $37^{\circ} \mathrm{C}$. Two-fold serial dilutions of test compounds (400-0.2 $\mu \mathrm{g} / \mathrm{mL})$ in DMEM with FBS were subsequently added and cells incubated for another 72 hours. The cytopathic effects of compounds were evaluated colorimetrically using the MTT Cell Proliferation Assay (ATCC). $\mathrm{IC}_{50}$ data were obtained from dose response curves plotted as percentage activity versus $\log _{10}$ concentration. 


\section{CHAPTER 4: OVERALL DISCUSSION OF RESEARCH PROJECTS}

\section{Introduction}

Both projects discussed in this dissertation involved the discovery of new antimicrobials to address the concerns associated with the increasing prevalence of drugresistant bacteria. The development of new antimicrobials is a major strategy toward overcoming the problems with drug resistance, as new compounds offer novel modes of action to which target pathogens are initially susceptible. My work involved the targeting of two different pathways: (1) the cell wall via inhibition of rhamnose biosynthesis, a key sugar in the makeup of the Mycobacterium tuberculosis cell wall; and (2) phospholipids via inhibition of phosphatidic acid biosynthesis, a key intermediate in the biosynthesis of bacterial phospholipids. Both of these projects involved the use of crossdisciplinary techniques from medicinal and organic chemistry, structural biology, computer modeling, biochemistry, and microbiology to discovery novel inhibitors of these pathways. The purpose of this chapter is to discuss some key themes throughout these projects and discuss future goals that will continue the success of this work.

\section{RmlC Project}

The first project reported in Chapter 2 discussed the discovery of novel inhibitors of cell wall biosynthesis in M. tuberculosis. The key concept in this project involved the use of structure based drug design, specifically computer aided drug design techniques. This work successfully combined the use of high throughput screening, database searching, virtual screening, and combinatorial chemistry to discovery novel inhibitors of $\mathrm{RmlC}$ as potential anti-TB drug candidates. High throughput screening was used to discover a hit molecule; $2 \mathrm{D}$ database searching was performed to find better high affinity hits; 3-D database searching provided new scaffolds for library development in the discovery of a lead; co-crystallography was performed in the development of a pharmacophore model as well as gain structural knowledge for rounds of virtual screening; virtual screening and docking were performed to generate and filter in silico libraries to produce a more focused and prioritized list of compounds for synthesis; synthesis of the compound libraries involved a combination of modern high throughput synthesis techniques: solution phase parallel synthesis with the use of solid phase reagents and microwave technology to expedite the reaction process.

In the synthesis of bi-aryl sulfonamides, modern technologies were used. It was very important to find a practical approach for rapid synthesis of these libraries. We discovered that the use of polymer supported catalysts ${ }^{142,143}$ in combination with microwave technology ${ }^{139}, 147$ expedited the synthesis of this library. Not only did it reduce the time to complete a normally sluggish reaction, but also cut down on purification of final products. With the polymer-supported catalysts for Suzuki cross coupling, we were able to work with mild, non-toxic reagents that were air and moisture stable. ${ }^{142,143}$ Also, at the completion of the reactions, the workup involved a simple 
filtration. The addition of microwave technology, not only decreased the time for synthesis, but helped the reactions go to completion with fewer by-products. In most cases, the reactions did not require further purification. These techniques were very successful in the rapid development of a 99-member bi-aryl sulfonamide library.

Both libraries of bi-aryl sulfonamides produced compounds that were found to inhibit RmlC in M. tuberculosis. These inhibitors contained important structural features observed with our pharmacophore model. However, the enzyme activity was generally weak $(<50 \%$ inhibition) and they did not present significant whole cell antimicrobial activity (MIC $\geq 25 \mu \mathrm{g} / \mathrm{mL}$ ). The lack of anti-tuberculosis activity is potentially due to poor penetration in the M. tuberculosis cell wall and low target enzyme inhibition. This is not unexpected owing to the nature of the complex cell wall of mycobacteria.

Although virtual screening is a successful in the discovery of high affinity leads, there are potential problems that prevent this method from being used solely in drug design. ${ }^{99,171-173}$ There are issues with the selection of target structure, selection of the most favorable docking program and selection of scoring functions. Particularly, there are many docking and scoring programs where the choice of program will have a major impact on the ultimate success of the study to identify validated leads. ${ }^{173}$ Major drawbacks involve the use of rigid body docking that cannot incorporate induced fit mechanisms and poor sampling over entropy which limits the success of these techniques. ${ }^{171,173}$ Previous work in our lab performed by Kerim Baboglu et al, using the aforementioned methods in this project, proved the success of our chosen docking and scoring programs. ${ }^{133}$ Many reviews have covered these issues and scientists are continually trying to improve these methods for their use in structure-based drug design. ${ }^{171,174-176}$ The development of leads in drug discovery programs generally involves the high throughput screening of libraries that exist in a particular collection which is often limited in chemical space and diversity. ${ }^{173}$ In silico library generation, associated with virtual screening, expands the possibilities of molecules that may not exist physically but can be readily obtained from commercial sources or through synthesis.

One of the shortcomings from both bi-aryl sulfonamide libraries were the selection of starting materials. The first library only offered a small select number of sulfonyl chlorides that could be obtained commercially and used in this library. The second library, a product of three points of diversity rather than the two in the first library, was more diverse in nature but was limited by the availability of building blocks that we possessed in-house for this pilot library. Future work in this project involves an attempt to enhance the diversity through expansion of this pilot library to a full library using our structure-guided approach of in silico library generation and docking to prioritize compounds for synthesis. In this library three points of diversity are introduced: boronic acids that mimic the thymine moiety, various sulfonyl chloride spacer groups to aid in proper binding conformations, and primary amines to further explore the sugar pocket. Using similar techniques in the generation of the first library, new compounds for synthesis were chosen. Three virtual libraries of 22,770 compounds were docked and scored. The top $2 \%$ compounds from each library were visually 
inspected and selected based on the following criteria: (1) $\mathrm{MW} \leq 500$; (2) $\mathrm{ClogP} \leq 5$; and (3) binding mode similar to dTDP-rhamnose with appropriate amino acid interactions. 15 representative compounds are proposed for synthesis to further this research (Figures 4.1-4.3). The synthesis of these compounds has been passed on to one of my lab mates and will be reported in due course.

\section{PIsY Project}

Chapter 3 described the discovery of novel inhibitors of the biosynthesis of phospholipids in Gram-positive bacteria. Due to the lack of structural knowledge of the PlsY enzyme, we employed a ligand-based drug design approach that involved the synthesis of substrate mimics using a bioisosteric replacement strategy to obtain a preliminary structure activity relationship. These compounds were tested for their enzyme inhibition activity and whole cell antimicrobial activity across a panel of clinically relevant bacteria. Several key inhibitors were discovered with good enzyme inhibition, good antimicrobial activity, and low cytotoxicity.

A recent publication of Paoletti et al demonstrated that plsX and plsY is essential in Gram-positive bacteria such as Bacillus subtilis. ${ }^{155}$ Deletion of the genes associated with plsX and plsY block phospholipids biosynthesis. ${ }^{155} \mathrm{PlsX}$ depletion results in the inhibition of total lipid synthesis without accumulation of fatty acids or other intermediates. ${ }^{155}$ This suggests a role of this pathway in fatty acid synthesis. The competitive inhibition of our compounds to PlsY causes a build up of acylphosphate which can be used in the reversible PlsX reaction to generate acyl-ACP. ${ }^{152}$ Acyl-ACP can then re-enter and block fatty acid synthesis. ${ }^{152}$ Additionally, the inhibitors of PlsY have long chains that are similar to those that are accumulated during fatty acid synthesis implying their potential to act as inhibitors of fatty acid biosynthesis causing a build up of intermediates which in turn will cause inhibition of the enzymes. ${ }^{177}$

I feel we have only scratched the surface toward the successful development of substrate mimics as inhibitors of phospholipids biosynthesis in Gram-positive bacteria. We have designed and synthesized the first known potent inhibitors of the PlsX/PlsY pathway which have significant antimicrobial activity in $B$. anthracis. The excellent activity in $B$. anthracis led us to do more research on $B$. anthracis and why the compounds had such a narrow spectrum activity, which revealed that $B$. anthracis has three $p l_{s} Y$ homologs in its genome. One of our current goals is to determine which enzyme or enzymes are responsible for the potent MIC activity.

The preliminary SAR studies led to the discovery of novel inhibitors for PlsY; however we need to further expand the library to include functional groups with more drug-like properties. There are two types of compounds I suggest that could further this project: reverse amide phosphonates and acylsulfamates. I would choose these two scaffolds because: (1) they are synthetically very tractable and it should be easy to synthesize expanded libraries in parallel; and (2) compounds with these scaffolds have already been synthesized, and were good inhibitors with good whole cell antimicrobial 


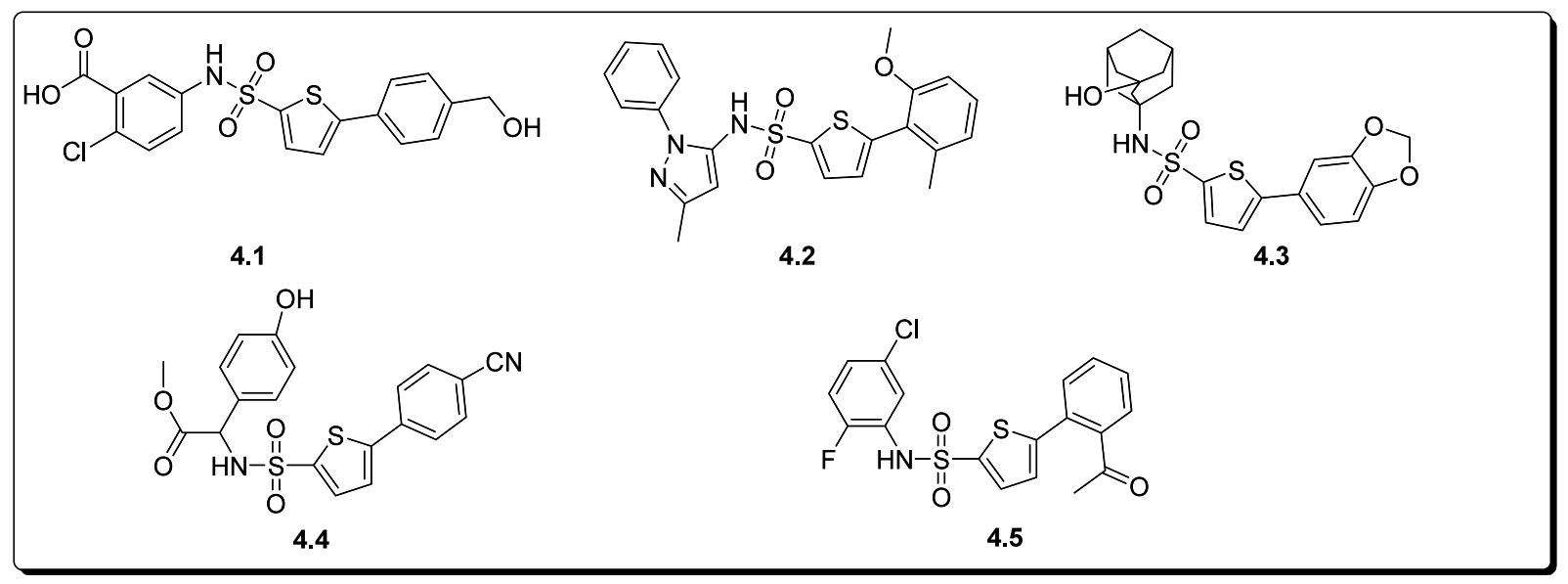

Figure 4.1: Compounds from Lib_1

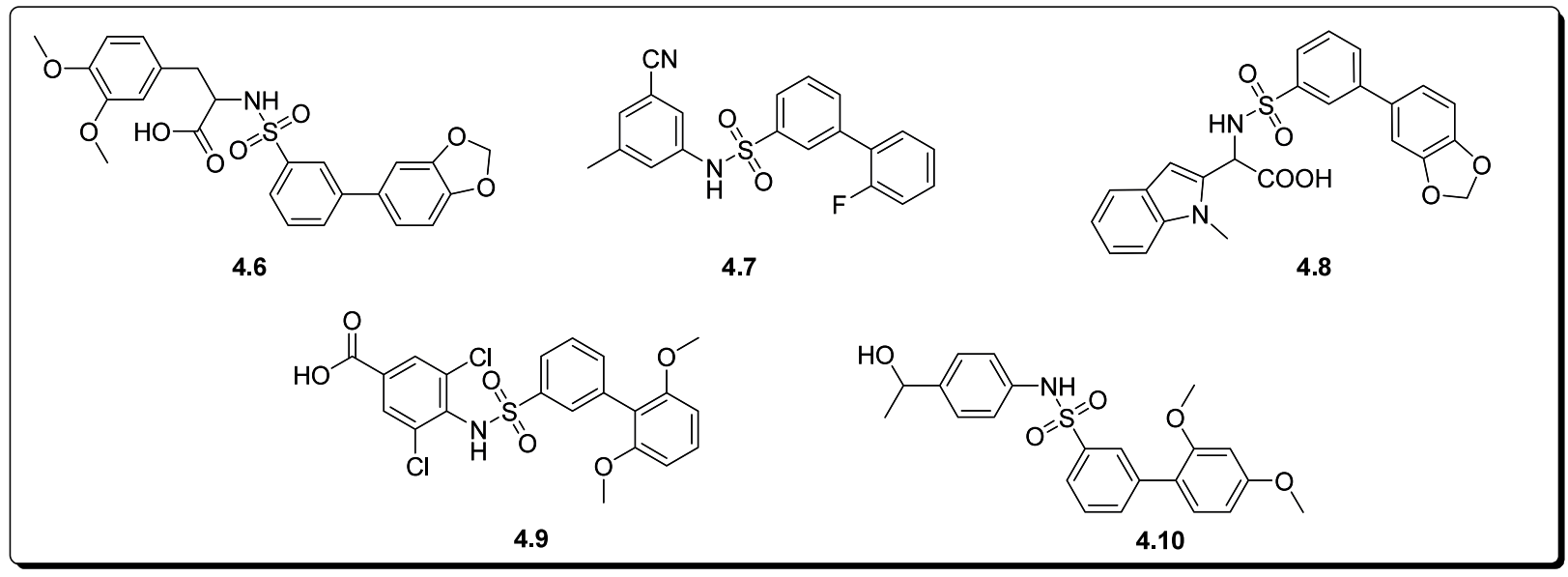

Figure 4.2: Compounds from Lib_2

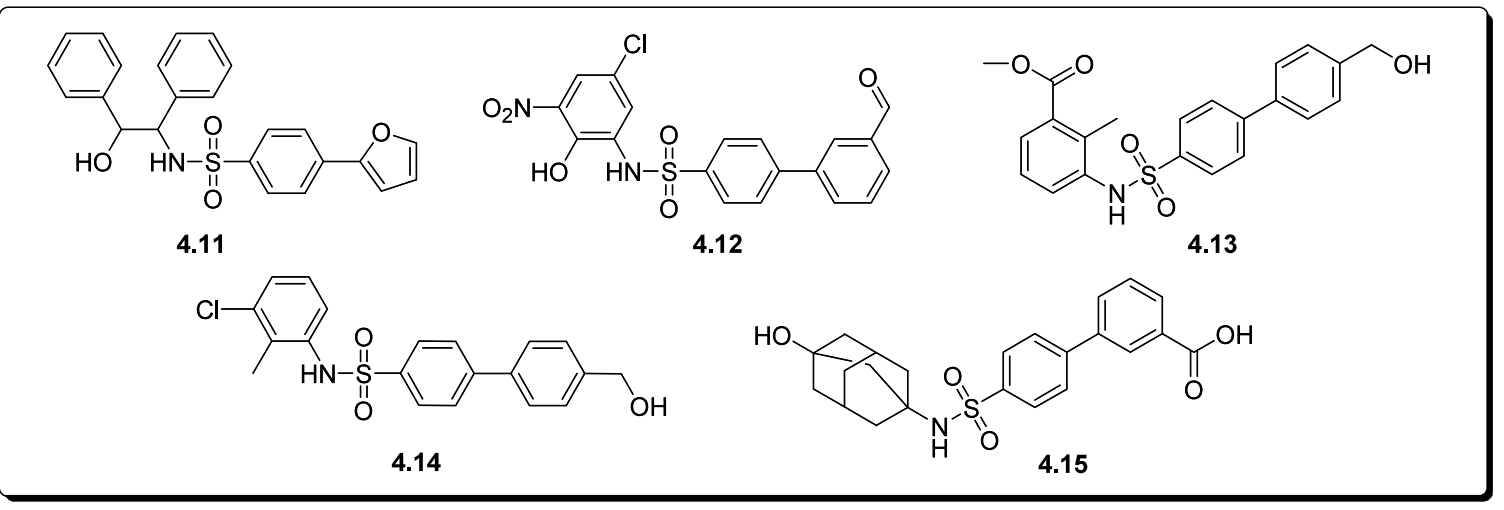

Figure 4.3: Compounds from Lib_3 
activity. In addition to the synthesis of more drug-like analogues of PlsY inhibitors, future work should also include inhibitors of PlsX. As discussed above, PlsX inhibition not only leads to blockade of phospholipid biosynthesis in Gram-positive bacteria, but also blocks total lipid synthesis. ${ }^{155}$ This shows the potential of inhibitors that can block fatty acid synthesis which is a proven target for antimicrobial design. There are crystal structure of two PlsX enzymes ${ }^{176}$ available, however not much is known about the specific active site of this enzyme. I believe the search for inhibitors of PlsX enzyme will be fertile ground for the development of new antimicrobial agents.

\section{Final Thoughts}

Medicinal chemistry is defined as a highly interdisciplinary science combining organic chemistry with biochemistry, computational chemistry, pharmacology, pharmacognosy, molecular and structural biology, statistics, and physical chemistry. ${ }^{96}$ The work outlined in these two projects utilized strategies and technologies from these areas in the successful discovery of potential candidates for antimicrobial drug design showing that no one discipline can work alone as it is important to have collaborations amongst other fields of study to flourish in any given project. Each discipline plays a critical role from the discovery of new therapeutic targets for which drugs can be designed and synthesized to the manufacturing and implement of these drugs to the market. Being a part of an interdisciplinary environment allows you to share your expertise in your field while learning more about other fields which is an important quality for continued success. I've had the opportunity to be exposed to several disciplines that have definitely broadened my understanding of the sciences and my effectiveness as a medicinal chemist. My hopes are that the importance of an interdisciplinary approach to drug design is incorporated in more graduate programs in order to produce a flood of well-rounded scientists that influence the field. 


\section{LIST OF REFERENCES}

1. Willams, D.; Lemke, T., Foye's Principles of Medicinal Chemistry. 5th ed.; Lippincott, Williams, \& Wilkins: Baltimore, MD, 2002.

2. Bermingham, A.; Derrick, J. P., The folic acid biosynthesis pathway in bacteria: evaluation of potential for antibacterial drug discovery. Bioessays 2002, 24, (7), $637-48$.

3. Finch, R. G.; Greenwood, D.; Norrby, S. R.; Whitley, R. J., Antibiotic and Chemotherapy: Anti-infective agents and theri use in therapy. 8th ed.; Churchill Livingstone, An imprint of Elsevier Science Limited: United Kingdom, 2003.

4. Domagk, G., Chemotherapy of Bacterial Infections. Dtsch Med Wochenschr 1935, 61, 250-3.

5. Fuller, A. T., Is p-aminobenzenesulfonamide the active agent in prontosil therapy? Lancet 1937, 1, 194-8.

6. Miller, A. K.; Bruno, P.; Berglund, R. M., The Effect of Sulfathiazole on the in Vitro Synthesis of Certain Vitamins by Escherichia coli. J Bacteriol 1947, 54, 9 (G20).

7. Miller, A. K., Proc Soc Exper Pathol Med 1944, 57.

8. Richey, D. P.; Brown, G. M., The biosynthesis of folic acid. IX. Purification and properties of the enzymes required for the formation of dihydropteroic acid. $J$ Biol Chem 1969, 244, (6), 1582-92.

9. Bock, L.; Miller, G. H.; Schaper, K. J.; Seydel, J. K., Sulfonamide structureactivity relationships in a cell-free system. 2. Proof for the formation of a sulfonamide-containing folate analog. J Med Chem 1974, 17, (1), 23-8.

10. Lacey, R. W., Mechanism of action of trimethoprim and sulphonamides: relevance to synergy in vivo. J Antimicrob Chemother 1979, 5, (B), 75-83.

11. Markowitz, N.; Quinn, E. L.; Saravolatz, L. D., Trimethoprim-sulfamethoxazole compared with vancomycin for the treatment of Staphylococcus aureus infection. Ann Intern Med 1992, 117, (5), 390-8.

12. Silverman, R. B., The Organic Chemistry of Drug Design and Drug Action. 2nd ed.; Elsevier Inc.: Burlington, MA, 2004.

13. Lee, B., Conformation of penicillin as a transition-state analog of the substrate of peptidoglycan transpeptidase. J Mol Biol 1971, 61, (2), 463-9. 
14. Batchelor, F. R.; Doyle, F. P.; Nayler, J. H.; Rolinson, G. N., Synthesis of penicillin: 6-aminopenicillanic acid in penicillin fermentations. Nature 1959, 183, (4656), 257-8.

15. Loder, B.; Newton, G. G.; Abraham, E. P., The cephalosporin C nucleus (7aminocephalosporanic acid) and some of its derivatives. Biochem J 1961, 79, 40816.

16. Birnbaum, J.; Kahan, F. M.; Kropp, H.; MacDonald, J. S., Carbapenems, a new class of beta-lactam antibiotics. Discovery and development of imipenem/cilastatin. Am J Med 1985, 78, (6A), 3-21.

17. Cooper, R.; Wells, J. S.; Sykes, R. B., Novel potentiators of beta-lactam antibiotics. Isolation of SQ28,504 and SQ28,546 from Chromobacterium violaceum. J Antibiot (Tokyo) 1985, 38, (4), 449-54.

18. Breuer, H.; Cimarust, i. C. M.; Denszel, T.; Koste, r. W. H.; Slusarchyk, W. A.; Treuner, U. D., Monobactams-structure-activity relationships leading to SQ26,776. J Antimicrob Chemother 1981, 8, (Suppl E), 21-28.

19. Livermore, D. M.; Williams, J. D., In-vitro activity of the monobactam, SQ 26,776 , against Gram-negative bacteria and its stability to their beta-lactamases. $J$ Antimicrob Chemother 1981, 8 Suppl E, 29-37.

20. Percival, A.; Thomas, E.; Hart, C. A.; Karayiannis, P., In-vitro activity of monobactam, SQ 26,776, against Gram-negative bacteria. J Antimicrob Chemother 1981, 8 Suppl E, 49-55.

21. Reeves, D. S.; Bywater, M. J.; Holt, H. A., Antibacterial activity of the monobactam SQ 26,776 against antibiotic resistant enterobacteria, including Serratia spp. J Antimicrob Chemother 1981, 8 Suppl E, 57-68.

22. Russell, A. D., In-vitro studies on SQ 26,776, a new monobactam antibiotic. $J$ Antimicrob Chemother 1981, 8 Suppl E, 81-8.

23. Lim, S. M.; Webb, S. A., Nosocomial bacterial infections in Intensive Care Units. I: Organisms and mechanisms of antibiotic resistance. Anaesthesia 2005, 60, (9), 887-902.

24. Parker, S. E.; Davey, P. G., Once-daily aminoglycoside administration in gramnegative sepsis. Economic and practical aspects. Pharmacoeconomics 1995, 7, (5), 393-402.

25. Duggar, B. M., Aureomycin; a product of the continuing search for new antibiotics. Ann N Y Acad Sci 1948, 51, (Art. 2), 177-81. 
26. Duggar, B. M. Aureomycin. 1949.

27. Chopra, I.; Roberts, M., Tetracycline antibiotics: mode of action, applications, molecular biology, and epidemiology of bacterial resistance. Microbiol Mol Biol Rev 2001, 65, (2), 232-60.

28. Champney, W. S.; Burdine, R., Macrolide antibiotics inhibit 50S ribosomal subunit assembly in Bacillus subtilis and Staphylococcus aureus. Antimicrob Agents Chemother 1995, 39, (9), 2141-4.

29. Culic, O.; Erakovic, V.; Parnham, M. J., Anti-inflammatory effects of macrolide antibiotics. Eur J Pharmacol 2001, 429, (1-3), 209-29.

30. Yoshida, H.; Nakamura, M.; Bogaki, M.; Ito, H.; Kojima, T.; Hattori, H.; Nakamura, S., Mechanism of action of quinolones against Escherichia coli DNA gyrase. Antimicrob Agents Chemother 1993, 37, (4), 839-45.

31. Marians, K. J.; Hiasa, H., Mechanism of quinolone action. A drug-induced structural perturbation of the DNA precedes strand cleavage by topoisomerase IV. J Biol Chem 1997, 272, (14), 9401-9.

32. Drlica, K.; Zhao, X., DNA gyrase, topoisomerase IV, and the 4-quinolones. Microbiol Mol Biol Rev 1997, 61, (3), 377-92.

33. Sugino, A.; Peebles, C. L.; Kreuzer, K. N.; Cozzarelli, N. R., Mechanism of action of nalidixic acid: purification of Escherichia coli nalA gene product and its relationship to DNA gyrase and a novel nicking-closing enzyme. Proc Natl Acad Sci U S A 1977, 74, (11), 4767-71.

34. Goldstein, E. J., Norfloxacin, a fluoroquinolone antibacterial agent. Classification, mechanism of action, and in vitro activity. Am J Med 1987, 82, (6B), 3-17.

35. Sensi, P.; Margalith, P.; Timbal, M. T., Rifomycin, a new antibiotic; preliminary report. Farmaco [Sci] 1959, 14, (2), 146-7.

36. Sensi, P.; Greco, A. M.; Ballotta, R., Rifomycin. I. Isolation and properties of rifomycin B and rifomycin complex. Antibiot Annu 1959, 7, 262-70.

37. Thiemann, J. E.; Hengeller, C.; Virgilio, A., Rifamycin. XXV: A group of actinophages active on Streptomyces mediterranei. Nature 1962, 193, 1104-5.

38. Coates, A. R.; Hu, Y., New strategies for antibacterial drug design: targeting nonmultiplying latent bacteria. Drugs R D 2006, 7, (3), 133-51.

39. Sefton, A. M., Mechanisms of antimicrobial resistance: their clinical relevance in the new millennium. Drugs 2002, 62, (4), 557-66. 
40. Miller, C. P.; Bohnhoff, M., The development of bacterial resistance to chemotherapeutic agents. Annu Rev Microbiol 1950, 4, 210-22.

41. MacLean, I. H.; Rogers, K. B.; Fleming, A., Lancet 1939, 1.

42. Salyers, A. A.; Whitt, D. D., Bacterial Pathogenesis: A Molecular Approach. 2nd ed.; ASM Press: Washington, D.C., 2002; p 150-81

43. Waterer, G. W.; Wunderink, R. G., Increasing threat of Gram-negative bacteria. Crit Care Med 2001, 29, (4 Suppl), N75-81.

44. Poole, K., Efflux-mediated antimicrobial resistance. J Antimicrob Chemother 2005, 56, (1), 20-51.

45. Nikaido, H., Multidrug efflux pumps of gram-negative bacteria. J Bacteriol 1996, $178,(20), 5853-9$.

46. Ball, P. R.; Shales, S. W.; Chopra, I., Plasmid-mediated tetracycline resistance in Escherichia coli involves increased efflux of the antibiotic. Biochem Biophys Res Commun 1980, 93, (1), 74-81.

47. McMurry, L.; Petrucci, R. E., Jr.; Levy, S. B., Active efflux of tetracycline encoded by four genetically different tetracycline resistance determinants in Escherichia coli. Proc Natl Acad Sci U S A 1980, 77, (7), 3974-7.

48. Kotra, L. P.; Haddad, J.; Mobashery, S., Aminoglycosides: perspectives on mechanisms of action and resistance and strategies to counter resistance. Antimicrob Agents Chemother 2000, 44, (12), 3249-56.

49. Berger-Bachi, B., Resistance mechanisms of gram-positive bacteria. Int J Med Microbiol 2002, 292, (1), 27-35.

50. Wickens, H.; Wade, P., Understanding Antibiotic Resistance. The Pharmaceutical Journal 2005, 274, 501-4.

51. Sutherland, R.; Boon, R. J.; Griffin, K. E.; Masters, P. J.; Slocombe, B.; White, A. R., Antibacterial activity of mupirocin (pseudomonic acid), a new antibiotic for topical use. Antimicrob Agents Chemother 1985, 27, (4), 495-8.

52. Parenti, M. A.; Hatfield, S. M.; Leyden, J. J., Mupirocin: a topical antibiotic with a unique structure and mechanism of action. Clin Pharm 1987, 6, (10), 761-70.

53. Zinner, S. H., The search for new antimicrobials: why we need new options. Expert Rev Anti Infect Ther 2005, 3, (6), 907-13. 
54. Thomas, K. S.; Smith, M. E., Version 2000: the new $\beta$-lactamases of Gramnegative bacteria at the dawn of the new millennium. Microbes Infect 2000, 2, 1225-35.

55. Poole, K., Overcoming antimicrobial resistance by targeting resistance mechanisms. J Pharm Pharmacol 2001, 53, (3), 283-94.

56. Buynak, J. D.; Ghadachanda, V. R.; Vogeti, L.; Zhang, H.; Chen, H., Synthesis and evaluation of 3-(carboxymethylidene)- and 3-(carboxymethyl)penicillinates as inhibitors of beta-lactamase. J Org Chem 2005, 70, (11), 4510-3.

57. Lienard, B. M.; Horsfall, L. E.; Galleni, M.; Frere, J. M.; Schofield, C. J., Inhibitors of the FEZ-1 metallo-beta-lactamase. Bioorg Med Chem Lett 2007, 17, (4), 964-8.

58. Morandi, F.; Caselli, E.; Morandi, S.; Focia, P. J.; Blazquez, J.; Shoichet, B. K.; Prati, F., Nanomolar inhibitors of AmpC beta-lactamase. J Am Chem Soc 2003, $125,(3), 685-95$.

59. Morandi, S.; Morandi, F.; Caselli, E.; Shoichet, B. K.; Prati, F., Structure-based optimization of cephalothin-analogue boronic acids as beta-lactamase inhibitors. Bioorg Med Chem 2008, 16, (3), 1195-205.

60. Nauton, L.; Kahn, R.; Garau, G.; Hernandez, J. F.; Dideberg, O., Structural insights into the design of inhibitors for the L1 metallo-beta-lactamase from Stenotrophomonas maltophilia. J Mol Biol 2008, 375, (1), 257-69.

61. Plantan, I.; Selic, L.; Mesar, T.; Anderluh, P. S.; Oblak, M.; Prezelj, A.; Hesse, L.; Andrejasic, M.; Vilar, M.; Turk, D.; Kocijan, A.; Prevec, T.; Vilfan, G.; Kocjan, D.; Copar, A.; Urleb, U.; Solmajer, T., 4-Substituted trinems as broad spectrum beta-lactamase inhibitors: structure-based design, synthesis, and biological activity. $J$ Med Chem 2007, 50, (17), 4113-21.

62. Venkatesan, A. M.; Agarwal, A.; Abe, T.; Ushirogochi, H.; Yamamura, I.; Kumagai, T.; Petersen, P. J.; Weiss, W. J.; Lenoy, E.; Yang, Y.; Shlaes, D. M.; Ryan, J. L.; Mansour, T. S., Novel imidazole substituted 6-methylidene-penems as broad-spectrum beta-lactamase inhibitors. Bioorg Med Chem 2004, 12, (22), 5807-17.

63. Weiss, W. J.; Petersen, P. J.; Murphy, T. M.; Tardio, L.; Yang, Y.; Bradford, P. A.; Venkatesan, A. M.; Abe, T.; Isoda, T.; Mihira, A.; Ushirogochi, H.; Takasake, T.; Projan, S.; O'Connell, J.; Mansour, T. S., In vitro and in vivo activities of novel 6-methylidene penems as beta-lactamase inhibitors. Antimicrob Agents Chemother 2004, 48, (12), 4589-96. 
64. Wyrembak, P. N.; Babaoglu, K.; Pelto, R. B.; Shoichet, B. K.; Pratt, R. F., Oaryloxycarbonyl hydroxamates: new beta-lactamase inhibitors that cross-link the active site. J Am Chem Soc 2007, 129, (31), 9548-9.

65. Bassetti, M.; Righi, E.; Viscoli, C., Novel beta-lactam antibiotics and inhibitor combinations. Expert Opin Investig Drugs 2008, 17, (3), 285-96.

66. Wright, G. D., Aminoglycoside-modifying enzymes. Curr Opin Microbiol 1999, 2, (5), 499-503.

67. Gao, F.; Yan, X.; Baettig, O. M.; Berghuis, A. M.; Auclair, K., Regio- and chemoselective 6'-N-derivatization of aminoglycosides: bisubstrate inhibitors as probes to study aminoglycoside 6'-N-acetyltransferases. Angew Chem Int Ed Engl 2005, 44, (42), 6859-62.

68. Gao, F.; Yan, X.; Shakya, T.; Baettig, O. M.; Ait-Mohand-Brunet, S.; Berghuis, A. M.; Wright, G. D.; Auclair, K., Synthesis and structure-activity relationships of truncated bisubstrate inhibitors of aminoglycoside 6'-N-acetyltransferases. J Med Chem 2006, 49, (17), 5273-81.

69. Welch, K. T.; Virga, K. G.; Whittemore, N. A.; Ozen, C.; Wright, E.; Brown, C. L.; Lee, R. E.; Serpersu, E. H., Discovery of non-carbohydrate inhibitors of aminoglycoside-modifying enzymes. Bioorg Med Chem 2005, 13, (22), 6252-63.

70. Vastola, A. P.; Altschaefl, J.; Harford, S., 5-epi-Sisomicin and 5-epi-Gentamicin B: substrates for aminoglycoside-modifying enzymes that retain activity against aminoglycoside-resistant bacteria. Antimicrob Agents Chemother 1980, 17, (5), 798-802.

71. Brenwald, N. P.; Gill, M. J.; Wise, R., The effect of reserpine, an inhibitor of multi-drug efflux pumps, on the in-vitro susceptibilities of fluoroquinoloneresistant strains of Streptococcus pneumoniae to norfloxacin. J Antimicrob Chemother 1997, 40, (3), 458-60.

72. Lomovskaya, O.; Zgurskaya, H. I.; Totrov, M.; Watkins, W. J., Waltzing transporters and 'the dance macabre' between humans and bacteria. Nat Rev Drug Discov 2007, 6, (1), 56-65.

73. Barrett, J. F., MC-207110 Daiichi Seiyaku/Microcide Pharmaceuticals. Curr Opin Investig Drugs 2001, 2, (2), 212-5.

74. Lomovskaya, O.; Warren, M. S.; Lee, A.; Galazzo, J.; Fronko, R.; Lee, M.; Blais, J.; Cho, D.; Chamberland, S.; Renau, T.; Leger, R.; Hecker, S.; Watkins, W.; Hoshino, K.; Ishida, H.; Lee, V. J., Identification and characterization of inhibitors of multidrug resistance efflux pumps in Pseudomonas aeruginosa: novel 
agents for combination therapy. Antimicrob Agents Chemother 2001, 45, (1), 10516.

75. Nelson, M. L.; Levy, S. B., Reversal of tetracycline resistance mediated by different bacterial tetracycline resistance determinants by an inhibitor of the Tet(B) antiport protein. Antimicrob Agents Chemother 1999, 43, (7), 1719-24.

76. Nelson, M. L.; Park, B. H.; Levy, S. B., Molecular requirements for the inhibition of the tetracycline antiport protein and the effect of potent inhibitors on the growth of tetracycline-resistant bacteria. J Med Chem 1994, 37, (9), 1355-61.

77. Fung, H. B.; Kirschenbaum, H. L.; Ojofeitimi, B. O., Linezolid: an oxazolidinone antimicrobial agent. Clin Ther 2001, 23, (3), 356-91.

78. Paladino, J. A., Linezolid: an oxazolidinone antimicrobial agent. Am J Health Syst Pharm 2002, 59, (24), 2413-25.

79. Steenbergen, J. N.; Alder, J.; Thorne, G. M.; Tally, F. P., Daptomycin: a lipopeptide antibiotic for the treatment of serious Gram-positive infections. $J$ Antimicrob Chemother 2005, 55, (3), 283-8.

80. Ackermann, G.; Rodloff, A. C., Drugs of the 21st century: telithromycin (HMR 3647)--the first ketolide. J Antimicrob Chemother 2003, 51, (3), 497-511.

81. Kasbekar, N., Tigecycline: a new glycylcycline antimicrobial agent. Am J Health Syst Pharm 2006, 63, (13), 1235-43.

82. Rose, W. E.; Rybak, M. J., Tigecycline: first of a new class of antimicrobial agents. Pharmacotherapy 2006, 26, (8), 1099-110.

83. Shah, P. M., The need for new therapeutic agents: what is the pipeline? Clin Microbiol Infect 2005, 11 Suppl 3, 36-42.

84. Black, M. T.; Hodgson, J., Novel target sites in bacteria for overcoming antibiotic resistance. Adv Drug Deliv Rev 2005, 57, (10), 1528-38.

85. Fuller, A. T.; Mellows, G.; Woolford, M.; Banks, G. T.; Barrow, K. D.; Chain, E. B., Pseudomonic acid: an antibiotic produced by Pseudomonas fluorescens. Nature 1971, 234, (5329), 416-7.

86. Pohlmann, J.; Brotz-Oesterhelt, H., New aminoacyl-tRNA synthetase inhibitors as antibacterial agents. Curr Drug Targets Infect Disord 2004, 4, (4), 261-72.

87. Hurdle, J. G.; O'Neill, A. J.; Chopra, I., Prospects for aminoacyl-tRNA synthetase inhibitors as new antimicrobial agents. Antimicrob Agents Chemother 2005, 49, (12), 4821-33. 
88. Zhang, Y. M.; White, S. W.; Rock, C. O., Inhibiting bacterial fatty acid synthesis. J Biol Chem 2006, 281, (26), 17541-4.

89. Heath, R. J.; Rock, C. O., Fatty acid biosynthesis as a target for novel antibacterials. Curr Opin Investig Drugs 2004, 5, (2), 146-53.

90. Wright, H. T.; Reynolds, K. A., Antibacterial targets in fatty acid biosynthesis. Curr Opin Microbiol 2007, 10, (5), 447-53.

91. Campbell, J. W.; Cronan, J. E., Jr., Bacterial fatty acid biosynthesis: targets for antibacterial drug discovery. Annu Rev Microbiol 2001, 55, 305-32.

92. Lu, H.; Tonge, P. J., Inhibitors of FabI, an Enzyme Drug Target in the Bacterial Fatty Acid Biosynthesis Pathway. Acc Chem Res 2008, 41, (1), 11-20.

93. Karlowsky, J. A.; Laing, N. M.; Baudry, T.; Kaplan, N.; Vaughan, D.; Hoban, D. J.; Zhanel, G. G., In vitro activity of API-1252, a novel FabI inhibitor, against clinical isolates of Staphylococcus aureus and Staphylococcus epidermidis. Antimicrob Agents Chemother 2007, 51, (4), 1580-1.

94. Park, H. S.; Yoon, Y. M.; Jung, S. J.; Kim, C. M.; Kim, J. M.; Kwak, J. H., Antistaphylococcal activities of CG400549, a new bacterial enoyl-acyl carrier protein reductase (FabI) inhibitor. J Antimicrob Chemother 2007, 60, (3), 568-74.

95. Fleischmann, R. D.; Adams, M. D.; White, O.; Clayton, R. A.; Kirkness, E. F.; Kerlavage, A. R.; Bult, C. J.; Tomb, J. F.; Dougherty, B. A.; Merrick, J. M.; et al., Whole-genome random sequencing and assembly of Haemophilus influenzae Rd. Science 1995, 269, (5223), 496-512.

96. Wikipedia, http://en.wikipedia.org/wiki/Medicinal_chemistry, accessed April 14, 2008.

97. Barker, J. J., Antibacterial drug discovery and structure-based design. Drug Discov Today 2006, 11, (9-10), 391-404.

98. Kubiyni, H., Structure-based design of enzyme inhibitors and receptor ligands. Curr Opin Drug Discov Devel 1998, 1, (1), 4-15.

99. Waszkowycz, B.; Perkins, T. D. J.; Sykes, R. A.; Li, J., Large-scale virtual screening for discoverying leads int he postgenomic era. IBM Sys J 2001, 40, (2), 360-76.

100. Larin, O. Combinatorial Chemisry Review, http://www.combichemsitry.com/, accessed April 14, 2008. 
101. Lipinski, C. A.; Lambardo, F.; Dominy, B. W.; Feeny, P. J., Experimental and computational approaches to estimate solubility and permeability in drug discovery and development settings. Adv Drug Deliv Rev 1997, 23, 3-25.

102. Verber, D. F.; Johnson, S. R.; Cheng, H. Y.; Smith, B. R.; Ward, K. W.; Kopple, K. D., Molecular Properties That Influence the Oral Bioavailability of Drug Candidates. J Med Chem 2002, 45, 2615-23.

103. Clark, D. E.; Pickett, S. D., Computational methods for the prediction of 'druglikeness'. Drug Discov Today 2000, 5, (2), 49-58.

104. Congreve, M.; Carr, R.; Murray, C.; Jhoti, H., A 'rule of three' for fragment-based lead discovery? Drug Discov Today 2003, 8, (19), 876-7.

105. Koch, R., Die Atiologie der Tuberkulose. Berliner Kliniscben Wocbenschift 1882, 15, 221-30.

106. Koch centennial supplement. 100th anniversary of the announcement of the discovery of the tubercle bacillus by Robert Koch, March 24, 1882. Am Rev Respir Dis 1982, 125, (3 Pt 2), 1-132.

107. Schlossberg, D., Tuberculosis. 3 ed.; Springer-Verlag: New York, NY, 1994.

108. Wayne, L. G., Dormancy of Mycobacterium tuberculosis and latency of disease. Eur J Clin Microbiol Infect Dis 1994, 13, (11), 908-14.

109. Flynn, J. L.; Chan, J., Tuberculosis: latency and reactivation. Infect Immun 2001, $69,(7), 4195-201$.

110. Selwyn, P. A.; Hartel, D.; Lewis, V. A.; Schoenbaum, E. E.; Vermund, S. H.; Klein, R. S.; Walker, A. T.; Friedland, G. H., A prospective study of the risk of tuberculosis among intravenous drug users with human immunodeficiency virus infection. N Engl J Med 1989, 320, (9), 545-50.

111. World Health Organization, http://www.who.int/mediacentre/factsheets/fs104/en/, accessed April 14, 2008.

112. First-line chemotherapy in the retreatment of bacteriological relapses of pulmonary tuberculosis following a shortcourse regimen. Lancet 1976, 1, (7952), 162-3.

113. Congress, U. S., The Continuing Challenge of Tuberculosis. US. Government Printing Office: Washington, DC, 1993; p 1-106.

114. Bernadou, J.; Nguyen, M.; Meunier, B., [The mechanism of action of isoniazid. A chemical model of activation]. Ann Pharm Fr 2001, 59, (5), 331-7. 
115. Vilcheze, C.; Jacobs, W. R., Jr., The mechanism of isoniazid killing: clarity through the scope of genetics. Annu Rev Microbiol 2007, 61, 35-50.

116. Cockerill, F. R., 3rd; Uhl, J. R.; Temesgen, Z.; Zhang, Y.; Stockman, L.; Roberts, G. D.; Williams, D. L.; Kline, B. C., Rapid identification of a point mutation of the Mycobacterium tuberculosis catalase-peroxidase (katG) gene associated with isoniazid resistance. J Infect Dis 1995, 171, (1), 240-5.

117. Yu, S.; Girotto, S.; Lee, C.; Magliozzo, R. S., Reduced affinity for Isoniazid in the S315T mutant of Mycobacterium tuberculosis KatG is a key factor in antibiotic resistance. J Biol Chem 2003, 278, (17), 14769-75.

118. Mariam, D. H.; Mengistu, Y.; Hoffner, S. E.; Andersson, D. I., Effect of rpoB mutations conferring rifampin resistance on fitness of Mycobacterium tuberculosis. Antimicrob Agents Chemother 2004, 48, (4), 1289-94.

119. Zhang, Y.; Wade, M. M.; Scorpio, A.; Zhang, H.; Sun, Z., Mode of action of pyrazinamide: disruption of Mycobacterium tuberculosis membrane transport and energetics by pyrazinoic acid. J Antimicrob Chemother 2003, 52, (5), 790-5.

120. Lee, R. E.; Protopopova, M.; Crooks, E.; Slayden, R. A.; Terrot, M.; Barry, C. E., $3 \mathrm{rd}$, Combinatorial lead optimization of $[1,2]$-diamines based on ethambutol as potential antituberculosis preclinical candidates. J Comb Chem 2003, 5, (2), 17287.

121. Yendapally, R.; Lee, R. E., Design, synthesis, and evaluation of novel ethambutol analogues. Bioorg Med Chem Lett 2008, 18, (5), 1607-11.

122. Telenti, A.; Philipp, W. J.; Sreevatsan, S.; Bernasconi, C.; Stockbauer, K. E.; Wieles, B.; Musser, J. M.; Jacobs, W. R., Jr., The emb operon, a gene cluster of Mycobacterium tuberculosis involved in resistance to ethambutol. Nat Med 1997, $3,(5), 567-70$.

123. Sreevatsan, S.; Stockbauer, K. E.; Pan, X.; Kreiswirth, B. N.; Moghazeh, S. L.; Jacobs, W. R., Jr.; Telenti, A.; Musser, J. M., Ethambutol resistance in Mycobacterium tuberculosis: critical role of embB mutations. Antimicrob Agents Chemother 1997, 41, (8), 1677-81.

124. Banerjee, A.; Dubnau, E.; Quemard, A.; Balasubramanian, V.; Um, K. S.; Wilson, T.; Collins, D.; de Lisle, G.; Jacobs, W. R., Jr., inhA, a gene encoding a target for isoniazid and ethionamide in Mycobacterium tuberculosis. Science 1994, 263, (5144), 227-30.

125. Mdluli, K.; Slayden, R. A.; Zhu, Y.; Ramaswamy, S.; Pan, X.; Mead, D.; Crane, D. D.; Musser, J. M.; Barry, C. E., 3rd, Inhibition of a Mycobacterium 
tuberculosis beta-ketoacyl ACP synthase by isoniazid. Science 1998, 280, (5369), 1607-10.

126. Barry, C. E., 3rd, Interpreting cell wall 'virulence factors' of Mycobacterium tuberculosis. Trends Microbiol 2001, 9, (5), 237-41.

127. Ma, Y.; Stern, R. J.; Scherman, M. S.; Vissa, V. D.; Yan, W.; Jones, V. C.; Zhang, F.; Franzblau, S. G.; Lewis, W. H.; McNeil, M. R., Drug targeting Mycobacterium tuberculosis cell wall synthesis: genetics of dTDP-rhamnose synthetic enzymes and development of a microtiter plate-based screen for inhibitors of conversion of dTDP-glucose to dTDP-rhamnose. Antimicrob Agents Chemother 2001, 45, (5), 1407-16.

128. Giraud, M. F.; Naismith, J. H., The rhamnose pathway. Curr Opin Struct Biol 2000, 10, (6), 687-96.

129. McNeil, M.; Daffe, M.; Brennan, P. J., Evidence for the nature of the link between the arabinogalactan and peptidoglycan of mycobacterial cell walls. $J$ Biol Chem 1990, 265, (30), 18200-6.

130. Giraud, M. F.; Leonard, G. A.; Field, R. A.; Berlind, C.; Naismith, J. H., RmlC, the third enzyme of dTDP-L-rhamnose pathway, is a new class of epimerase. Nat Struct Biol 2000, 7, (5), 398-402.

131. Kantardjieff, K. A.; Kim, C. Y.; Naranjo, C.; Waldo, G. S.; Lekin, T.; Segelke, B. W.; Zemla, A.; Park, M. S.; Terwilliger, T. C.; Rupp, B., Mycobacterium tuberculosis RmlC epimerase (Rv3465): a promising drug-target structure in the rhamnose pathway. Acta Crystallogr D Biol Crystallogr 2004, 60, (Pt 5), 895902.

132. Babaoglu, K. Use of modern structure-based drug design techniques in the discovery and development of novel antimicrobial candidates. Ph.D. dissertation, University of Tennessee Health Science Center, 2004.

133. Babaoglu, K.; Page, M. A.; Jones, V. C.; McNeil, M. R.; Dong, C.; Naismith, J. H.; Lee, R. E., Novel inhibitors of an emerging target in Mycobacterium tuberculosis; substituted thiazolidinones as inhibitors of dTDP-rhamnose synthesis. Bioorg Med Chem Lett 2003, 13, (19), 3227-30.

134. Tripos, http://www.tripos.com, accessed April 14, 2008.

135. Sigma-Aldrich, http://www.sigmaaldrich.com, accessed April 14, 2008.

136. Maybridge, http://www.maybridge.com, accessed April 14, 2008. 
137. Rarey, M.; Kramer, B.; Lengauer, T.; Klebe, G., A fast flexible docking method using an incremental construction algorithm. J Mol Biol 1996, 261, (3), 470-89.

138. Clark, M.; Cramer, R. D.; N., V. O., Validation of the general purpose tripos 5.2 force field. J Comp Chem 1989, 10, (8), 982-1012.

139. Novabiochem, Microwave accelerated Suzuki couplings employing a polymersupported palladium phosphine. In Novabiochem innovations 02/04, EMD Biosciences Inc: 2004.

140. Littke, A.; Dai, C.; Fu, G., Versatile Catalysts for the Suzuki Cross-Coupling of Arylboronic Acids with Aryl and Vinyl Halides and Triflates under Mild Conditions. J Am Chem Soc 2000, 122, 4020-8.

141. Miyaura, N.; Suzuki, A., Chem Rev 1995, 95, 2457.

142. Argonaut, Polymer-Bound Triphenylphosphine-Pd(0). In Technical Note 517, Argonaut Technologies: 2003.

143. Parrish, C.; Buchwald, S., Use of Polymer-Supported Dialkylphosphinobiphenyl Ligands for Palladium-Catalyzed Amination and Suzuki Reactions. J Org Chem 2001, 66, 3820-7.

144. Hayes, B., Microwave Synthesis: Chemistry at the Speed of Light. CEM Publishing: Matthews, NC, 2002.

145. Kappe, C. O.; Dallinger, D., The impact of microwave synthesis on drug discovery. Nat Rev Drug Discov 2006, 5, (1), 51-63.

146. Mavandadi, F.; Pilotti, A., The impact of microwave-assisted organic synthesis in drug discovery. Drug Discov Today 2006, 11, (3-4), 165-74.

147. Blettner, C.; Konig, W.; Stenzel, W.; Schotten, T., Microwave-Assisted Aqueous Suzuki Cross-Coupling Reactions. J Org Chem 1999, 64, 3885-90.

148. Coates, A.; Hu, Y.; Bax, R.; Page, C., The Future Challenges Facing The Development of New Antimicrobial Drugs. Nat Rev Drug Discov 2002, 1, 895910.

149. Heath, R. J.; White, S. W.; Rock, C. O., Inhibitors of fatty acid synthesis as antimicrobial chemotherapeutics. Appl Microbiol Biotechnol 2002, 58, (6), 695703.

150. Heath, R. J.; White, S. W.; Rock, C. O., Lipid biosynthesis as a target for antibacterial agents. Prog Lipid Res 2001, 40, (6), 467-97. 
151. Cronan, J. E., Bacterial Membrane Lipids: Where Do We Stand? Annu Rev Microbiol 2003, 57, 203-24.

152. Zhang, Y. M.; Rock, C. O., Acyltransferases in bacterial glycerophospholipid synthesis. J Lipid Res 2008.

153. Lu, Y.-J.; Zhang, Y.-M.; Grimes, K. D.; Qi, J.; Lee, R. E.; Rock, C. O., AcylPhosphates Initiate Membrane Phospholipid Synthesis in Gram-Positive Pathogens. Mol Cell 2006, 23, 765-72.

154. Jacobs, M. A.; Alwood, A.; Thaipisuttikul, I.; Spencer, D.; Haugen, E.; Ernst, S.; Will, O.; Kaul, R.; Raymond, C.; Levy, R.; Chun-Rong, L.; Guenthner, D.; Bovee, D.; Olson, M. V.; Manoil, C., Comprehensive transposon mutant library of Pseudomonas aeruginosa. Proc Natl Acad Sci U S A 2003, 100, (24), 14339-44.

155. Paoletti, L.; Lu, Y. J.; Schujman, G. E.; de Mendoza, D.; Rock, C. O., Coupling of fatty acid and phospholipid synthesis in Bacillus subtilis. J Bacteriol 2007, 189, (16), 5816-24.

156. Lehninger, A., The Synthesis and Properties of the Acyl Phosphates of Some Higher Fatty Acids. J Biol Chem 1946, 162, (2), 333-42.

157. Somu, R. V.; Wilson, D. J.; Bennett, E. M.; Boshoff, H. I.; Celia, L.; Beck, B. J.; Barry, C. E., 3rd; Aldrich, C. C., Antitubercular nucleosides that inhibit siderophore biosynthesis: SAR of the glycosyl domain. J Med Chem 2006, 49, (26), 7623-35.

158. Vannada, J.; Bennett, E. M.; Wilson, D. J.; Boshoff, H. I.; Barry, C. E., 3rd; Aldrich, C. C., Design, synthesis, and biological evaluation of betaketosulfonamide adenylation inhibitors as potential antitubercular agents. $\mathrm{Org}$ Lett 2006, 8, (21), 4707-10.

159. Somu, R. V.; Boshoff, H.; Qiao, C.; Bennett, E. M.; Barry, C. E., 3rd; Aldrich, C. C., Rationally designed nucleoside antibiotics that inhibit siderophore biosynthesis of Mycobacterium tuberculosis. $J$ Med Chem 2006, 49, (1), 31-4.

160. Qiao, C.; Wilson, D. J.; Bennett, E. M.; Aldrich, C. C., A mechanism based aryl carrier protein/thiolation domain affinity probe. $J$ Am Chem Soc 2007, 129, 63501.

161. Tang, K.-C.; Coward, J. K.; , Synthesis of Acyl Phosphonate Analogues of Biologically Important Acyl Phosphates: N-2-Amino-10-methylpteroyl)-5amino-2-oxopentanephosphonic acid. J Org Chem 1983, 48, 5001-6.

162. Berkowitz, D. B.; Eggen, M.; Shen, Q.; Shoemaker, R. K., Ready Access to Fluorinated Phosphonate Mimics of Secondry Phosphates. Synthesis of the (a,a- 
Difluoroalkyl)phosphonate Analogues of 1-Phosphoserine, 1phosphoallothreonine, and 1-phosphotheronine. J Org Chem 1996, 61, 4666-75.

163. Adams, L. A.; Cox, R. J.; Gibson, J. S.; Mayo-Martin, M. B.; Walter, M.; Whittingham, W., A new synthesis of phosphoramidates: inhbitors of the key bacterial enzme aspartate semi-aldehyde dehydrogenase. Chem Comm 2002, 18, 2004-5.

164. Schulbach, M. C.; Mahapatra, S.; Macchia, M.; Barontini, S.; Papi, C.; Minutolo, F.; Bertini, S.; Brennan, P. J.; Crick, D. C., Purification, Enzymatic Characterization, and Inhibition of the Z-Farnesyl Diphosphate Synthase from Mycobacterium tuberculosis. J Biol Chem 2001, 276, (15), 11624-30.

165. Appel, R.; Berger, G., Chem Ber 1959, 91, 1339-41.

166. Fruit, C.; Muller, P., Intramolecular Asymmetric Amidation of Sulfonamides and Sulfamates Catalyzed by Chiral Dirhodium (II) Complexes. Hev Chim Acta 2004, $87,1607-15$.

167. Lee, C.-H.; Kohn, H., Intra- and Intermolecular a-Sulfamidoalkylation Reactions. J Org Chem 1990, 55, 6098-104.

168. Green, B. D.; Battisti, L.; Koehler, T. M.; Thorne, C. B.; Ivins, B. E., Demonstration of a capsule plasmid in Bacillus anthracis. Infect Immun 1985, 49, (2), 291-7.

169. Luna, V. A.; King, D. S.; Peak, K. K.; Reeves, F.; Heberlein-Larson, L.; Veguilla, W.; Heller, L.; Duncan, K. E.; Cannons, A. C.; Amuso, P.; Cattani, J., Bacillus anthracis virulent plasmid pX02 genes found in large plasmids of two other Bacillus species. J Clin Microbiol 2006, 44, (7), 2367-77.

170. Luna, V. A.; King, D. S.; Gulledge, J.; Cannons, A. C.; Amuso, P. T.; Cattani, J., Susceptibility of Bacillus anthracis, Bacillus cereus, Bacillus mycoides, Bacillus pseudomycoides and Bacillus thuringiensis to 24 antimicrobials using Sensititre automated microbroth dilution and Etest agar gradient diffusion methods. $J$ Antimicrob Chemother 2007, 60, (3), 555-67.

171. Kitchen, D. B.; Decornez, H.; Furr, J. R.; Bajorath, J., Docking and scoring in virtual screening for drug discovery: methods and applications. Nat Rev Drug Discov 2004, 3, (11), 935-49.

172. Koh, J. T., Making virtual screening a reality. Proc Natl Acad Sci U S A 2003, $100,(12), 6902-3$.

173. McInnes, C., Virtual screening strategies in drug discovery. Curr Opin Chem Biol 2007, 11, (5), 494-502. 
174. Warren, G. L.; Andrews, C. W.; Capelli, A. M.; Clarke, B.; LaLonde, J.; Lambert, M. H.; Lindvall, M.; Nevins, N.; Semus, S. F.; Senger, S.; Tedesco, G.; Wall, I. D.; Woolven, J. M.; Peishoff, C. E.; Head, M. S., A critical assessment of docking programs and scoring functions. $J$ Med Chem 2006, 49, (20), 5912-31.

175. Sherman, W.; Day, T.; Jacobson, M. P.; Friesner, R. A.; Farid, R., Novel procedure for modeling ligand/receptor induced fit effects. $J$ Med Chem 2006, 49, (2), 534-53.

176. Chen, J.; Anderson, J. B.; DeWeese-Scott, C.; Fedorova, N. D.; Geer, L. Y.; He, S.; Hurwitz, D. I.; Jackson, J. D.; Jacobs, A. R.; Lanczycki, C. J.; Liebert, C. A.; Liu, C.; Madej, T.; Marchler-Bauer, A.; Marchler, G. H.; Mazumder, R.; Nikolskaya, A. N.; Rao, B. S.; Panchenko, A. R.; Shoemaker, B. A.; Simonyan, V.; Song, J. S.; Thiessen, P. A.; Vasudevan, S.; Wang, Y.; Yamashita, R. A.; Yin, J. J.; Bryant, S. H., MMDB: Entrez's 3D-structure database. Nucleic Acids Res 2003, 31, (1), 474-7.

177. Cronan, J. E., Bacterial membrane lipids: where do we stand? Annu Rev Microbiol 2003, 57, 203-24. 


\section{VITA}

Kimberly D. Grimes is a native of Memphis, TN, graduating from Raleigh Egypt High School in May 1997 as salutatorian of her class. She accepted a full scholarship to the University of Tennessee, Chattanooga where she earned her Bachelors of Science degree in Chemistry in May 2001. After graduation, she spent a year working at Woodson-Tenenat Laboratories as an analyst in her hometown. In August 2002, she joined the Department of Pharmaceutical Sciences, Medicinal Chemistry Program at the University of Tennessee Health Science Center (UTHSC) under the mentorship of Dr. Richard Lee. Through her tenure at UTHSC, Kimberly thoroughly enjoyed her jobs of graduate teaching assistant, mentor, and tutor as she plans to become a research professor at an undergraduate university. Kimberly has plans of graduating from UTHSC in May 2008. 